
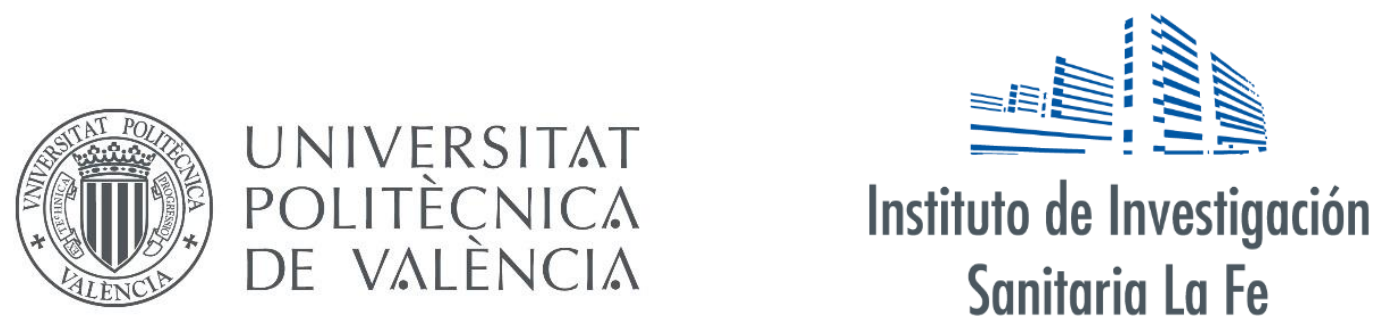

\title{
Estudio del papel de los miRNAs y las vesículas extracelulares derivadas de células mesenquimales estromales en la patología cardiaca
}

\author{
Rafael Sánchez Sánchez
}

Director de Tesis: Pilar Sepúlveda Sanchís

Co-Director Tesis: Akaitz Dorronsoro Gonzalez

Tutor UPV: Maria Desamparados Pascual-Ahuir Giner

$09 / 2021$ 
«No desesperes, ni siquiera por el hecho de que no desesperas. Cuando todo parece terminado, surgen nuevas fuerzas. Esto significa que vives.»

Franz Kafka 


\section{AGRADECIMIENTOS}

En primer lugar, me gustaría dar las gracias a mi directora de tesis la doctora Pilar Sepúlveda por darme la oportunidad de poder realizar mi tesis doctoral en la Unidad de Medicina Regenerativa y Trasplante Cardiaco. Por dirigir el trabajo realizado durante este periodo siempre confiando en nuestra capacidad y apostando por nuestro futuro, permitiendo desarrollar nuestra capacidad investigadora como pocos jefes harían. Ha sido para mí un placer poder trabajar en su laboratorio y confío en que ese ambiente se mantenga por mucho tiempo.

A mis queridos post-docs en especial a Akaitz Dorronsoro por ser mi co-director de tesis y habernos pegado juntos contra un sinfín de contratiempos, me ha enseñado casi todo lo que sé de un laboratorio siempre incentivando la curiosidad de esa manera suya tan didáctica. Ha sido un gran maestro que siempre recordaré con cariño pero más allá de un maestro, siempre será un gran amigo. A Imelda Ontoria por guiarme con su experiencia, ya no solo en el ámbito de laboratorio, sino en muchos aspectos donde su guía me ayudó a resolver situaciones complejas, y cómo no por traernos el mejor embutido y queso para asegurarse de que todo el laboratorio se alimente en condiciones.

Al equipo CIPF, Marieta, Hernán, Sandra y Nahuel que me adoptaron en el laboratorio cuando no tenía ni idea y me enseñaron muchísimo, aquellos primeros meses siempre serán un gran recuerdo inolvidable. Aquellas tardes larguísimas de sacar exosomas en el CIPF, los almuerzos en la terracita, e incluso las discusiones por las tijeras, o el TEMED (que luego resulto que estaba en la mochila de Hernán) en las que me encontraba en el centro de la trifulca. A Hernán, espero que te vaya fenomenal en esta etapa que estas viviendo, eres un investigador genial y estoy seguro de que conseguirás grandes cosas. A Sandra, mi compañera de cardiomiocitos, te deseo lo mejor en tu tesis y que tengas mucho éxito en tu vida profesional y a Marieta, espero verte pronto por el laboratorio con esas ganas y ese buen rollo que te caracteriza.

A mis compañeros de laboratorio, a mi Martiña, que me ha dado más de un tirón de oreja por desordenar el laboratorio, eres una persona genial y espero que no cambies nunca esa manera de ser que tienes, hemos compartido tanto que te considero como una hermana, siempre tendrás en mi un amigo incondicional. A Marc Buigues, poderoso fundador de halo de Buigues y del término "buiguiano", compañero inseparable de juergas e inquebrantable bebedor de cazalla. Espero que nunca pierdas esa pasión que tienes a la hora de abordar cualquier cosa que te planteas.

A Nacho Reinal, alias poochie, mi compañero friki de ver anime, videojuegos, escapes room y juegos de mesa. Se que tendrás un futuro brillante tanto a nivel profesional como personal, y quizá dentro de muchos años cuando estudies mucho, seas capaz de ganarme al futbolín jeje. A Elena Amaro, que empezó como infiltrada espía en el laboratorio y terminó siendo la mitad inseparable del dream team del futbolín, gramola-humana y una gran amiga. Eres una excelente persona, amable y generosa como pocas, siempre dispuesta a echarte un cable si lo necesitas o a dejarte $500 \mu \mathrm{L}$ de EVs si te hacen falta!

A Marina Piquer por ser mi compañera infartadora de ratas, de horas y horas en animalario intentando intubar ratas con Melendi de fondo. Profesional destructora de todas las operaciones bikini del laboratorio con su arsenal de chucherías. Espero que sigamos quedando para jugar, pintar e ir a comer con ese espíritu jovial que te caracteriza, eres genial! A Rosita darle las gracias por aguantarme todos estos años y atormentarla con los pedidos y los cortes, eres una grandísima persona. A Amparito por tener esa energía y ese espíritu envidiable que nos alegra a todos, A los nuevos retoños del laboratorio, Marta Jungle, mi joven padawan 
espero grandes cosas de ti, hemos compartido poco tiempo pero consigues que la gente se sienta cómoda a tu lado. Siento no haberte podido dedicar todo el tiempo que me hubiera gustado pero ojalá tengas una tesis genial, tienes unos grandes compañeros y puedes aprender muchísimo de todos ellos, trabaja duro porque es un trabajo exigente pero sobre todo, disfruta. A Silvia Selvitella, espero que puedas desarrollar toda esa capacidad y entusiasmo por la ciencia que llevas dentro, las personas que aman lo que hacen como lo haces tú finalmente encuentra el camino de una manera u otra. A Marilú Cassini por ese buen rollo que genera cuando está, espero que cuando te hagas famosa te acuerdes de nosotros! En general a todo el equipo del IISLAFE, responsables de microscopia, cultivos, citometría etc que hace posible este trabajo

En definitiva, sabéis que no miento si aseguro que este laboratorio ha sido para mí como una segunda casa y todos los integrantes mi familia. Sois todos geniales y espero que ese espíritu que reina en el laboratorio nunca desaparezca.

A mi familia, en especial a mis padres, que siempre me han apoyado en todos mis proyectos, son para mí un pilar fundamental de mi vida y es un orgullo para mi poder llamarme hijo suyo. A mi hermana Ana por todas esas tardes de desconexión compartiendo un ratito de ordenador o simplemente charlando, eres la mejor y sabes que te adoro.

Por último, a Noelia mi pareja, has sido apoyo incondicional para mí en todas las facetas de mi vida, siempre dándome ánimos creyendo y confiando en mí. No habría podido hacer esto sin ella ni ser quien soy. 
1.Fisiopatología del corazón ___ 21

1.1 Definición y epidemiología de la enfermedad___ 21

1.1.1 Factores de Riesgo _ 21

1.2 Tipos de patología cardiaca __ 22

1.2.1 Miocardiopatía isquémica___ 23

1.2.2 El daño por reperfusión __ 24

1.2.3 Cardiotoxicidad derivada de antraciclinas ___ 31

2. Terapia celular____ 37

2.1 Contexto histórico de la terapia celular __ 37

2.2 Células MSC _ 38

2.2.1 MSC en la terapia cardiaca___ 40

3. Vesículas extracelulares (EVs) _

3.1 Definición de vesículas extracelulares___ 42

3.2 Biogénesis y liberación de partículas___ 43

3.3 Métodos de aislamiento y caracterización __ 44

3.4 Caracterización de las vesículas extracelulares __ 46

3.5 Papel de las EVs en la terapia cardiaca ___ 49

3.5.1 EVs derivadas de cardiomiocitos en comunicación celular.___ 49

3.5.2 EVs derivadas de otros tipos celulares como terapia cardiaca __ 50

3.5.3 Uso de EVs vs células __ 51

4.miRNAs ___ 51

4.1 Definición de los miRNAs__ 51

4.2 Papel de los miRNAs en la terapia cardiaca __ 52

HIPOTESIS Y OBJETIVOS _ 55

Hipótesis ___ 56

MATERIALES Y MÉTODOS _

1.Inclusión de pacientes____ 59

1.1 Parámetros clínicos _ 60

1.2 Ecocardiografía —— 60

1.3 Extracción de muestras de pacientes __ 60

2. Métodos Informáticos ___ 61

2.1 Estadística y figuras___ 61

2.2 Secuenciamiento miRNA___ 61

2.3 Generación de algoritmo predictivo____ 62

2.4 Estudio del Interactoma ___ __ 62

2.5 Análisis proteómicos___ 63

3.Métodos bioquímicos ___ 63

3.1 Extracción de miRNAs y qPCR___ 63

3.2 Transcripción inversa____ 64

3.3 Cuantificación de miRNA por qPCR___ 64

3.4 Extracción de proteínas ___ 65

3.5 Cuantificación de proteínas ___ 66

3.5 Western Blot __ 66

3.7 Inmunofluorescencia ____ 69

4.Modelos celulares ___ 69 
4.1 Medios de cultivo utilizados

4.2 Aislamiento de cardiomiocitos neonatales de rata___ 71

4.3 Medios de cultivo en condiciones de isquemia ___ 72

4.4 Infección de las células mesenquimales_____ 72

4.4.1 Transformación de bacterias__________ 73

4.4.2 Crecimiento bacteriano y aislamiento del plásmido____ 73

4.4.3 Generación de los lentivirus ___ 74

4.4.4 Titulación del virus____ 74

4.5 Transfección de células con miRNAs ___ 75

5. Aislamiento de vesículas extracelulares____ 75

5.1 Caracterización de las vesículas___ 76

5.2 Electroporación de vesículas ___ 78

6. Ensayos en modelos celulares___ 78

6.1 Ensayo de captación de vesículas __ 78

6.2 Ensayo de estrés oxidativo____ 79

6.3 Ensayo de Captación de Doxorrubicina____ 79

6.4 Ensayo de formación de tubos ______ 79

6.5 Ensayo de CCK8 ___ 80

6.6 Ensayo de Anexina por citometría de flujo ____ 80

6.7 Ensayo de Wound Healing in vitro ___ 81

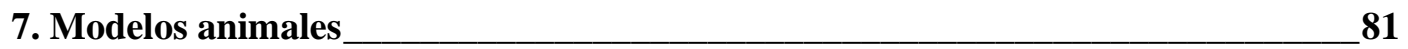

7.1 Modelo de infarto mediante ligadura permanente ____ 81

7.2 Ecocardiografía de ratas nude __ 82

7.3 Sacrifico y fijación del corazón ___ 82

7.4 Inyección de doxorrubicina _____ 83

7.3 Modelo de angiogénesis in vivo mediante Plug de Matrigel ___ 83

7.3 Histoquímica ___ 84

7.3.1 Parafinización del tejido ___ 84

7.3.2 Desparafinación del tejido __ 84

7.3.3 Tricrómico de Mason ___ 84

7.3.4 Rojo Sirio ___

RESULTADOS 86

1. Estudio de la comunicación intercelular cardiaca ___ 87

1.1 Aislamiento y caracterización de vesículas en cardiomiocitos ___ 87

1.1.1 Caracterización del contenido de las vesículas________ 88

1.2 Las vesículas de AC10 en condiciones de Hipoxia y Normoxia no tienen efecto en la multiplicación en líneas celulares cardiacas.

1.3 Las vesículas derivadas de cardiomiocitos en hipoxia son captadas preferencialmente en endotelio

1.4 Las vesículas derivadas de AC10 en Normoxia inducen un efecto angiogénico sobre las derivadas en hipoxia

1.5 Las vesículas derivadas de AC10 en estado de hipoxia inducen un aumento de la migración en fibroblastos ___ 93

2. Estudio prospectivo de miRNAs circulantes pacientes con cáncer de mama___ 95

2.1 Caracterización de la cohorte de pacientes ___ 95

2.2 Generación de lista de miRNAs diferencialmente expresados entre casos y controles ___ 98

2.3 Integración de resultados miRNAseq____ 98

2.4 Evaluación de niveles de miRNA a lo largo del tratamiento quimioterapéutico ____ 99

2.5 Selección de miRNAs diferencialmente expresados ___ 100 
2.6 Evaluación de los niveles de miRNA seleccionados

2.7 Validación del RNAseq por qPCR

1.7.1 Valores en la cohorte principal___ 102

1.7.2 Valores en la cohorte de validación ___ 102

2.8 Generación de algoritmo de predicción de cardiotoxicidad__________ 103

2.9 Estudio de las vías de señalización afectadas por el conjunto de miRNAs seleccionados_ 105

2.9.1 Enumeración de procesos biológicos diferencialmente expresados ___ 105

2.9.2 Red de interacción de miRNAs con procesos biológicos relevantes ___ 107

1.9.3 Procesos biológicos regulados por miRNAs diferencialmente expresados ___ 108

\section{Potencial terapéutico de las EVs de MSCs en la cardiotoxicidad derivada de} antraciclinas

3.1 Generación de línea de mesenquimales inmortal MSC-TERT

3.1.2 Caracterización de las vesículas MSC-TERT

2 Las vesículas derivadas de MSC-TERT ejercen efecto terapéutico en el modelo de daño por doxorrubicina.

3.3 Las vesículas derivadas de MSCs-TERT reducen los niveles de ROS en cardiomiocitos tratados con doxorrubicina

3.4 La adicción de EVs-MSC sobre un cultivo de cardiomiocitos reduce la cantidad de doxorrubicina captada por ellos

3.6 El tratamiento con EVs no reduce la cantidad de doxorrubicina captada por células tumorales

3.7 Las EVs derivadas de MSC-TERT mejoran la angiogénesis en células endoteliales tratadas con doxorubicina

3.8 Las vesículas de MSC-TERT no afectan a la supervivencia de los fibroblastos en el daño mediado por doxorrubicina

3.9 El tratamiento de fibroblastos con EVs reduce la capacidad de migración de los fibroblastos

3.10 Las EVs derivadas de las MSC-TERT reducen marcadores de inducción a miofibroblastos, así como la generación de matriz extracelular

3.11 Modelos animales supervivencia con vesículas 118

3.11.1 La inyección conjunta de EVs y doxorrubicina protege frente a la bajada de peso de los ratones

3.11.1 La inyección de doxorrubicina a dosis aguda no ejerce un efecto fibrótico en el corazón

\section{Estudio del contenido de miRNA en las vesículas de MSC}

4.1 Comparación de niveles de miRNA en vesículas MSC frente a MSC-TERT.

4.2 Presencia de miRNAs involucrados en la función cardiaca en las vesículas extracelulares 121

\section{Relación entre los niveles de miRNA y la patología cardiaca}

5.1 Los niveles de miRNAs involucrados en la cardiotoxicidad varían sus niveles en células cardiacas después de un tratamiento con doxorrubicina

$5.2 \mathrm{El}$ aumento de los niveles de estos miRNAs vía transfección ejerce un efecto protector sobre los cardiomiocitos en el daño por doxorrubicina 123 5.4 La transfección del miRNA 4732-3p no ejerce un efecto proliferativo en líneas de cáncer de mama

\section{Potencial terapéutico de las vesículas extracelulares derivadas de MSC-TERT y} miRNA 4732-3p en el daño por isquemia.

6.1 Las vesículas derivadas de MSC-TERT así como el miRNA 4732-3p reducen el número de cardiomiocitos en estado de apoptosis después de un periodo isquémico

6.2 El miRNA 4732-3p y las MSC-EVs reducen los niveles de estrés oxidativo en 
6.3 Variación de marcadores celulares en cardiomiocitos tratados con MSC-EVs y miRNA 4732-3p

6.4 Las vesículas derivadas de MSC-TERT ejercen una protección frente a la perdida de contracción de los cardiomiocitos in vitro 128 6.5 El tratamiento con miRNA 4732-3p disminuye los marcadores de fibrosis $\alpha$-SMA y Col1 A

6.6 El tratamiento con el miRNA 4732-3p induce una menor movilidad de los fibroblastos _ 131

6.7 El miRNA 4732 aumenta la angiogénesis in vitro en células endoteliales 132

$6.8 \mathrm{El}$ miRNA 4732-3p induce angiogénesis en modelo in vivo 133

6.9 Efecto de las EVs y el miRNA 4732-3p en el modelo de isquemia in vivo 134

DISCUSIÓN

1. Las vesículas Extracelulares derivadas de cardiomiocitos juegan un papel importante en la comunicación intercelular 138

2. Perfil diferencial de miRNAs en pacientes con cáncer de mama_____ 141

3. El papel de las vesículas derivadas de MSC-TERT en la terapia contra el daño inducido por la doxorrubicina. 146

4. miRNAs en el tratamiento de la patología cardiaca 149

CONCLUSIONES 154 


\section{ABREVIATURAS}

IC: Insuficiencia Cardiaca

HDL: Lipoproteína de alta densidad

Ca: Calcio

ROS: Especies reactivas de oxigeno

NADPH: Nicotinamida Dinucleótido Fosfato

NOS: Óxido Nítrico Sintasa

NAD: Nicotinamida dinucleótido

O: Oxígeno

ATP: Adenina-Tri-fosfato

Fe: Hierro

TNF: Factor de necrosis tumoral

HIF: Factor inducible de hipoxia

NO: Oxido Nítrico

BH4: Tetrahidrobiopterina

ADP: Adenina-Di-fosfato

AMP: Adenina-Mono-fosfato

IMP: Inosin-Mono-fosfato

BCL-2: Linfoma células B-2

BAD: Promotor asociado de muerte de Bcl-2

BAX: Proteína X asociada a BCL-2

HTRA2: Serina Peptidasa 2

PCI: Inyección percutánea

NA/H: Sodio/Protón

FEVI: Fracción de eyección del ventrículo izquierdo

TnI: Troponina I

LV: Ventrículo Izquierdo

RV: Ventrículo Derecho

MUGA: Adquisición de sincronización múltiple

SAPKS: Proteína kinasa activada por stress.

JNK: Kinasa termina N-Jun

DNA: Acido desoxirribonucleico

TGF- $\beta$ : Factor de crecimiento transformante beta

TLR: Receptores tipo Toll

NFKB: Factor nuclear potenciador de las cadenas ligeras Kappa

FDA: Administración de alimentos y medicamentos

CRISPR-CAS9: Repeticiones Palindrómicas Cortas Agrupadas y Regularmente Espaciadas

HSC: Célula madre hematopoyética

MSC: Células mesenquimales estromales 
CD: Cluster de diferenciación

HLA: Complejo principal de histocompatibilidad

BM: Médula ósea

EVS: Vesículas Extracelulares

RNA: Ácido ribonucleico

mRNA: Ácido ribonucleico mensajero

miRNA micro-Ácido ribonucleico

tRNA: Ácido ribonucleico transferencia
A: Adenina
C: Citosina
G: Guanina
T: Timina
U: Uracilo
M: Molar

KDA: Kilodalton

PEG: Polietilenglicol

HSP: Proteína de Shock térmico

TSG101: Gen susceptible de tumor 101

ANXA: Anexina A1

FBN: Fibronectina

FC: Citometría de flujo

NTA: Análisis de Nanotracking

iPSC: Célula madre pluripotente inducida

STAT3: Transductor de señal y activador de la transcripción 3

CPCS: Células cardiacas pluripotentes

PDC: Células dendríticas plasmocíticas

UTR: Región no traducida

GATA: Factor de transcripción de globulina A

MAPK: Protein Kinasas activadas por mitógenos

BH3: Trihidrobiopterina

SIRT1: Sirtuina 1

VEGF: Factor de crecimiento vascular-endotelial

Rhoa: Miembro A de la familia homologa de Ras

IGF1R: Receptor 1 del factor de crecimiento a insulina

TAC: Taxotere, Adriamicina, Ciclofosfamida

AC: Adriamicina, ciclofosfamida

HER: Factor de crecimiento epidérmico humano 2 
ROC: Característica operativa del receptor

AUC: Área bajo la curva

GO: Ontología Génica

RIPA: Buffer de ensayo de radioinmunoprecipitación

LC-MS/MS: Cromatografía líquida Masa/Masas

q-PCR: Reacción en cadena de la polimerasa cuantitativa

RT: Retrotranscripción

cDNA: Ácido desoxirribonucleico de cadena doble

${ }^{\circ} \mathrm{C}$ : Grados Celsius

BCA: Ensayo de ácido bicinconinico

WB: Western Blot

MQ: MilliQ

SDS: Dodecil Sulfato Sódico

APS: Persulfato Amónico

TEMED: Tetrametiletilendiamina

PVDF: Difluoruro polivinil

TBS: Tris-Buffer Salino

PFA: Paraformaldehido

DAPI: 4 ',6-diamidino-2-fenilindol

HUVEC: Células endoteliales de la vena umbilical

HCAEC: Células endoteliales de arteria coronaria humana

DMEM: Dulbecco's Modified Eagle

FBS: Suero Bovino fetal

HBSS: Solución salina balanceada de Hank

EDTA: Acido etilendiaminotetracético

$\mathrm{Mg}$ : Magnesio

PBS: Tampón fosfato sódico

LB: Caldo de lisogenia

GFP: Proteína verde fluorescente

CCD: Dispositivo de carga acoplada

CFSE: Succinimidil-Carboxifluorescencina

FACS: Clasificador de células activado por fluorescencia

CCK8: Kit contador de células 8

IP: Ioduro de Propidio

NX: Normoxia

HX: Hipoxia

FB: Fibroblastos 
EC: Células endoteliales

TERT: Telomerasa transcriptasa inversa

COL1A: Colágeno $1^{a}$

ACTA2: Actomiosina 2

CDH: Cadherina

CNX43: Conexina 43

IR: Isquemia/reperfusión

NC: Control negativo

FGF: Factor de crecimiento de fibroblastos

PTEN: fosfatidilinositol-3,4,5-trisfosfato 3-fosfatasa

Top2B: Topoisomerasa 2B

GLS: Deformación longitudinal global

TIMP-1: Inhibidor de metalopeptidasa 1

Angtp-1: Angiopoietina 1

FGFR: Receptor del factor de crecimiento de fibroblastos 


\section{RESUMEN}

Actualmente la insuficiencia cardiaca es una de las principales causas de mortalidad y co-morbilidad a nivel mundial sobre todo en países desarrollados. Este tipo de patología a su vez, se desglosa en un gran abanico de posibles agentes que perturban el funcionamiento del músculo cardiaco en función de su causa. Uno de los problemas más importantes a niveles de afectación cardiaca se centra en pacientes que sufren algún tipo de cáncer y son tratados con antraciclinas. Estas drogas ampliamente usadas en el mundo de la oncología, tienen una serie de efectos secundarios entre los cuales destaca su posible efecto cardiotóxico. Este trabajo ahonda sobre este proceso y sobre la existencia de un perfil de paciente con una susceptibilidad a sufrir este tipo de episodios de toxicidad cardiaca. En este sentido, se investiga una serie de miRNAs que se encuentran diferencialmente expresados en pacientes que sufren este tipo de episodios frente a los que no. Una vez se detectan estos miRNA generamos un algoritmo predictor mediante el cual somos capaces de predecir si un paciente sufrirá cardiotoxicidad en función de la cantidad de ciertos miRNAs presentes en suero.

Una vez descubiertos estos miRNAs nos centramos en la búsqueda de una posible opción terapéutica para esta serie de eventos. Para ello usamos las vesículas extracelulares (EVs) derivadas de células mesenquimales estromales (MSC), unas células que han demostrado tener un alto potencial terapéutico y de gran seguridad. Se evaluó su capacidad terapéutica en el daño inducido por doxorrubicina y posteriormente se amplió el estudio añadiendo el daño por isquemia reperfusión en diferentes frentes como puede ser la regeneración cardiaca, inhibición de la fibrosis o neoangiogénesis.

Aunque es necesario un estudio más exhaustivo de los perfiles de cardiotoxicidad y de los mecanismos de acción tanto de los miRNAs como de las EVs, esta tesis demuestra la capacidad de ambos como una potente herramienta tanto de diagnóstico como terapéutica. 


\section{SUMARY}

Heart failure is currently one of the main causes of mortality and co-morbidity worldwide, especially in developed countries. This type of pathology, can be broken down into a wide range of possible agents that disturb the functioning of the cardiac muscle depending on its cause. One of the most important problems in terms of cardiac involvement is centered on patients who suffer from some type of cancer and are treated with anthracyclines. These drugs, widely used in the world of oncology, have a series of side effects, among which their possible cardiotoxic effect stands out. This work delves into this event and into the existence of a patient profile with a susceptibility to suffer this type of episodes of cardiac toxicity. In this sense, we investigate a series of miRNAs that are differentially expressed in patients who suffer this type of episodes versus those who do not. Once these miRNAs were detected, we generated a predictive algorithm by which we are able to predict whether a patient will suffer cardiotoxicity based on the amount of certain miRNAs present in serum.

Once these miRNAs were discovered, we focused on the search for a possible therapeutic option for this series of events. For this we used extracellular vesicles (EVs) derived from mesenchymal cells (MSC), cells that have been shown to have a high therapeutic potential and high safety. We tested their therapeutic capacity in doxorubicin injury and later extended the study by adding ischemia reperfusion injury on different fronts such as cardiac regeneration, inhibition of fibrosis or neoangiogenesis.

Although a more exhaustive study of the cardiotoxicity profiles and mechanisms of action of both miRNAs and EVs is needed, this thesis demonstrates the capacity of both as a powerful diagnostic and therapeutic tool. 


\section{RESUM}

Actualment la insuficiència cardíaca és un dels principals causes de mortalitat i co-morbiditat a nivell mundial sobretot en països desenvolupats. Aquest tipus de patologia al seu torn, es desglossa en un gran ventall de possibles agents que pertorben el funcionament de l'múscul cardíac en funció de la seva causa. Un dels problemes més importants a nivells d'afectació cardíaca se centra en pacients que pateixen algun tipus de càncer i són tractats amb antraciclines. Aquestes drogues àmpliament usades en el món de l'oncologia, tenen una sèrie d'efectes secundaris entre els quals destaca el seu possible efecte cardiotòxic. Aquest treball aprofundeix sobre aquest succés i sobre ha un perfil de pacient amb una susceptibilitat a patir aquest tipus d'episodis de toxicitat cardíaca. En aquest sentit s'investiga una sèrie de miRNAs que es troben diferencialment expressats en pacients que pateixen aquest tipus d'episodis enfront dels que no. Un cop es detecten aquests miRNA generem un algoritme predictiu mitjançant el qual, som capaços de predir si un pacient patirà cardiotoxicitat en funció de la quantitat de certs miRNAs presents en sèrum.

Un cop descoberts aquests miRNAs ens centrem en la recerca d'una possible opció terapèutica per a aquesta sèrie d'esdeveniments. Per a això fem servir les vesícules extracelulres derivades de cèlllules mesesnquimales, unes cèllules que han demostrat tenir un alt potencial terapuetico i de gran seguretat. Es testen la seva capacitat terapèutica en el dany per doxurbicina i posteriorment s'amplia l'estudi afegint el dany per isquèmia reperfusió en diferents fronts com pot ser la regeneració cardíaca, inhibició de la fibrosi o neoangiogènesi.

Encara que és necessari un estudi més exhaustiu dels perfils de cardiotoxicitat i dels mecanismes d'acció tant dels miRNAs com de les EVs, aquesta tesi demostra la capacitat de tots dos com una potent eina tant de diagnòstic com terapuetica. 


\section{INTRODUCCIÓN}




\section{Fisiopatología del corazón}

\subsection{Definición y epidemiología de la enfermedad}

La insuficiencia cardiaca (IC) se define como un síndrome clínico complejo derivado de un fallo estructural y/o funcional en la capacidad de llenado o eyección ventricular. Esta definición engloba una gran cantidad de patologías cardiovasculares diferentes que conducen a un suministro insuficiente de oxígeno para satisfacer las demandas metabólicas ${ }^{1,2}$. Estas diferentes patologías difieren tanto en tiempo como en síntomas progresión etc. Todo esto hace que la capacidad de prognosis de la IC sea muy difícil de medir y requiera de múltiples criterios para hacer una diagnosis ${ }^{3}$.

La prevalencia de la insuficiencia cardiaca se encuentra entre índices de 3-20 de cada 1000 habitantes dependiendo de los criterios del estudio. Esta prevalencia aumenta con la edad siendo de un 0.6 por cada 1.000 habitantes en pacientes por debajo de los 65 años, ratio que se encuentra en continuo aumento durante las últimas décadas ${ }^{4,5}$. La incidencia anual de IC se encuentra en 2 nuevos casos por cada 1.000 habitantes entre 45-54 años mientras que en pacientes entre 85-94 años es de 40 casos por cada 1.000 habitantes ${ }^{6}$. Se estima que la prevalencia en USA es de 83 millones siendo responsable de 1 de cada 3 muertes?

Se calcula que la IC ocasiona un gasto a los sistemas sanitarios a nivel mundial de unos 108 mil millones de dólares tanto en gastos directos (65 mil millones) como en gastos indirectos a través de problemas de morbilidad, mortalidad prematura o falta de productividad (43 mil millones). Debido al aumento de la esperanza de vida o la expansión poblacional se prevé que los presupuestos dedicados a esta patología aumenten ${ }^{6,8}$.

\subsubsection{Factores de Riesgo}

La insuficiencia cardiaca puede ser consecuencia de multitud de patologías previas que en última instancia reflejan un fallo en la estructura y función del miocardio. Los corazones con esta patología pueden llegar a desarrollarla de una manera progresiva o instantánea. Existen una gran cantidad de factores de riesgo asociados a la patología cardiaca de los cuales se destacan los siguientes ${ }^{9}$.

-Disminución de la lipoproteína de alta densidad (HDL). Resultados de estudios importantes, como puede ser el estudio de Quebec en el cual se hacía un seguimiento a pacientes durante 5 años, demostró que una concentración 
baja de HDL en plasma se asocia con angina de esfuerzo, insuficiencia coronaria e infarto no fatal de miocardio ${ }^{10,11}$.

-Consumo de tabaco: De las muertes producidas por el tabaco las enfermedades cardiovasculares corresponden un $29 \%$ de estas e incrementa el riesgo de sufrir una enfermedad cardiovascular entre 2 y 3 veces ${ }^{12}$. Incluso se ha demostrado que personas no consumidoras de tabaco que se encuentren en un ambiente de fumadores tienen incrementado el riesgo de sufrir enfermedades coronarias en un $20 \%^{13,14}$.

-Hipertensión: Existe una fuerte asociación entre la hipertensión y la posibilidad de sufrir una IC. Esta patología además afecta a una gran parte de la población y en muchos de estos casos se encuentra silente para los propios pacientes ${ }^{15-17}$.

-Obesidad: Aproximadamente el 38\% de los pacientes con insuficiencia cardiaca padecen de obesidad. En casos de personas obesas se han detectado anormalidades hemodinámicas y cambios estructurales en el corazón, debido posiblemente al aumento de la cantidad de masa magra que presentan ${ }^{18}$. A pesar de esto, se encuentra descrito que, aunque las personas obesas tengan un mayor riesgo a sufrir una IC, las personas obesas con patología cardiovascular tienen un mejor pronóstico que las que no son obesas. A esto se le conoce como la paradoja de la obesidad y actualmente se cree que es altamente dependiente de parámetros como el tipo y localización de los depósitos de grasa y el bienestar cardiorrespiratorio ${ }^{19}$.

\subsection{Tipos de patología cardiaca}

Las enfermedades cardiacas pueden dividirse en múltiples categorías en función al tipo de alteración que se produzca en el músculo cardiaco. Las diferentes patologías cardiacas ocurren como consecuencia de anormalidades en las células que conforman al corazón o a alteraciones en la funcionalidad de las mismas generando como consecuencia una función anómala del corazón. Dentro de estas patologías, la miocardiopatía isquémica y cardiotoxicidad derivada de antraciclinas tienen un carácter predominante. Mientras que la cardiotoxicidad no es tan prevalente en la sociedad actual, cada vez está adquiriendo una mayor importancia debido al aumento de la supervivencia en el cáncer. 


\subsubsection{Miocardiopatía isquémica}

Esta patología es resultante del desprendimiento o erosión de una placa de ateroma que da lugar a una oclusión trombótica de una arteria coronaria epicárdica. Existen dos arterias coronarias principales, la arteria coronaria derecha y la izquierda que a su vez se divide en la arteria circunflexa y la izquierda descendiente anterior. Normalmente la sangre oxigenada se suple a las arterias coronarias justo después de salir del ventrículo izquierdo. El infarto ocurre cuando se cesa el flujo de sangre por parte de una o más arterias coronarias. Esto conlleva una deprivación de nutrientes y oxígeno en toda la zona que irriga esta arteria ocluida, lo cual genera una zona infartada en la que se producen una serie de procesos de muerte celular. El tamaño final del infarto dependerá del tiempo de oclusión y la magnitud del fluido sanguíneo colateral. El infarto empezará en las capas subendocárdicas del corazón y progresa hacia los bordes de la zona de riesgo mientras dure la oclusión ${ }^{21}$.

El infarto de miocardio y su posterior reperfusión genera una serie de alteraciones en el corazón que se caracterizan por rupturas de mitocondrias, rupturas del sarcolema, destrucción de la microvasculatura, hemorragia e infiltración leucocitaria. Se produce una sobrecarga de calcio lo cual da lugar a una liberación oscilatoria de este por el retículo sarcoplásmico resultando en una descoordinada y excesiva contracción miocárdica. Además de esto se produce una digestión del citoesqueleto y el sarcolema mediado por las calpaínas, así como una excesiva formación de especies reactivas de oxígeno (ROS) que contribuyen a la muerte celular ${ }^{22,23}$.

La cardiopatía isquémica es la enfermedad cardiaca más prevalente a nivel mundial afectando a un total de 126 millones de individuos ( $1,72 \%$ de la población mundial) y siendo el causante de aproximadamente 9 millones de muertes a nivel global ${ }^{24,25}$. Debido a múltiples factores como el aumento en la esperanza de vida o la presencia de factores de riesgo en más del $70 \%$ de la población como obesidad, diabetes etc. se prevee que el ratio de prevalencia aumente desde un 1,655 por cada 100.000 habitantes a 1,845 para el año $2030^{24}$. Según la World Heart Federation el coste de esta enfermedad es de aproximadamente 863 mil millones de dólares suponiendo un coste del $10 \%$ de los presupuestos sanitarios, cifra que se estima que aumentará hasta sobrepasar el billón de dólares en el año $2030^{26}$. 


\subsubsection{El daño por reperfusión}

A pesar de que la reperfusión es de vital importancia para salvar la mayor cantidad de tejido cardiaco posible, este proceso también genera un daño que puede ser irreversible y se manifiesta mediante un área de infarto incrementada y disfunción microvascular. Este daño causa un aumento de la permeabilidad capilar o edema, microembolización coronaria de partículas ateroscleróticas, liberación de sustancias vasoconstrictoras por parte de la lesión aterosclerótica y destrucción de capilares y hemorragia ${ }^{21,27,28}$.

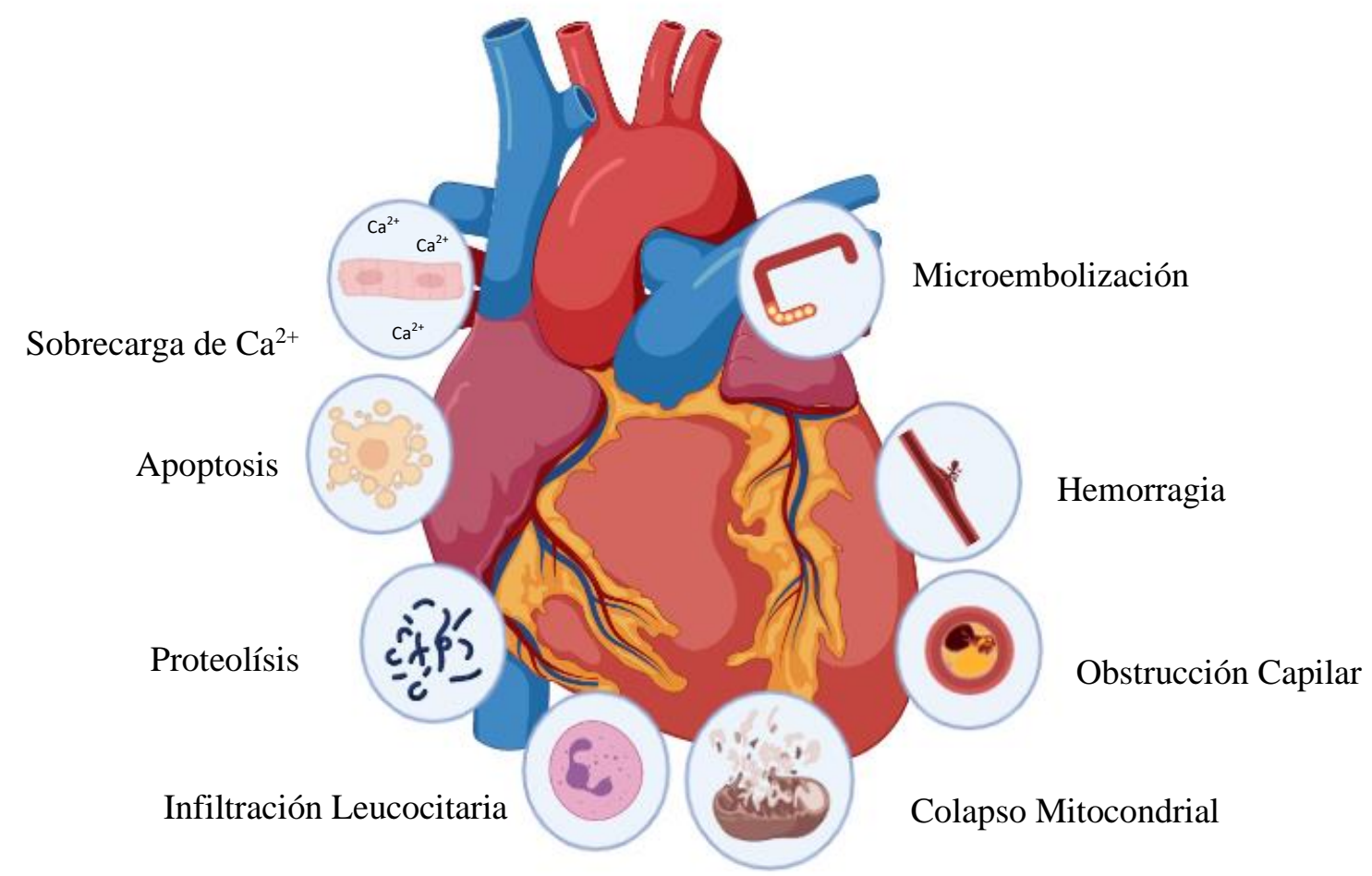

Figura 1: Esquema de los procesos importantes que intervienen en los mecanismos de daño en el proceso de isquemia reperfusión. Imagen Adaptada de: The pathophysiology of acute myocardial infarction and strategies of protection beyond reperfusion: a continual challenge . 774784 (2017) doi:10.1093/eurheartj/ehw224.

\subsubsection{Principales mecanismos de acción del daño por isquemia/reperfusión}

El daño total que se produce durante un infarto agudo de miocardio es principalmente causado por la hipoxia y la hiponutrición en el tejido. Después de una isquemia prolongada los productos metabólicos de las células son retenidos causando una acidosis metabólica. Cuando se reestablece el flujo sanguíneo en la zona se deriva lo que se conoce como daño secundario o daño por reperfusión. En esta zona se produce 
ahora un aumento de ROS así como una inflamación que pueden causar apoptosis, autofagia, necrosis o necroptosis. En los casos moderados, la isquemia/reperfusión puede causar disfunción celular por autofagia y activar vías de recuperación o supervivencia. Sin embargo, si el daño es severo, la muerte celular puede inducirse por vías de apoptosis o necrosis ${ }^{28,29}$.

\section{Generación de ROS}

Las especies reactivas de oxígeno o ROS son moléculas pequeñas altamente reactivas que se forman como un subproducto del metabolismo normal del oxígeno. Sin embargo, en condiciones isquémicas pueden aumentar en gran manera, lo que genera daños en las estructuras presentes en la célula. Este ROS puede producirse tanto de manera enzimática como no enzimática, siendo su producción en exceso el principal desencadenante ${ }^{30}$. Las fuentes enzimáticas incluyen el sistema de xantina oxidasa, sistema NADPH oxidasa, cadena transportadora de electrones o el desacoplamiento del sistema NOS. En cuanto a las fuentes no enzimáticas cabe destacar que son solo una pequeña proporción del ROS que se genera y se deben generalmente a la hemoglobina y la mioglobina en daños extremos ${ }^{31}$.

- Xantina oxidasa

Se trata de un mecanismo que juega un papel muy importante en el catabolismo de las purinas. Dentro de este mecanismo se encuentran enzimas como la xantina deshidrogenasa y la xantina oxidasa. Estas enzimas tienen dos formas, xantina deshidrogenas, que usa preferencialmente el NAD+ como aceptor de electrones, y la xantina oxidasa que usa el $\mathrm{O}_{2}$ como aceptor. Durante la oxidación de la hipoxantina a xantina en las células normales existe una reducción simultanea del $\mathrm{NAD}+\mathrm{o} \mathrm{O}_{2}$ produciendo $\mathrm{NADH}^{32}$. En un estado isquémico la xantina deshidrogenasa cambia a xantina oxidorreductasa debido a los niveles bajos de ATP. El ROS producido por la xantina oxidorreductasa activa cascadas de señalización y en última instancia las condiciones patológicas de la vía ${ }^{33}$.

\section{- NADPH oxidasa}

Esta familia de proteínas se encarga del transporte electrónico a través de las membranas. En condiciones de normoxia estas enzimas genera ion superóxido que es rápidamente derivado a la formación de peroxinitritos, nitración de la tirosina y reducción de centros de Fe vía aconitasa ${ }^{34} 35$. En condiciones isquémicas se liberan una serie de mediadores como $\mathrm{TNF} \alpha$, angiotensina o fosfolipasa 2 que inducen un aumento en la expresión de la vía generando de esta manera un exceso de ROS. Este 
mecanismo se encuentra a su vez regulado por proteínas como HIF-1 $\alpha$ que, ante una condición isquémica, se activa y aumenta la creación de enzimas de degradación del peróxido $^{36}$.

\section{- NOS}

Estas enzimas producen óxido nítrico (NO) por la conversión de la L-arginina en Lcitrulina. El NO actúa como antioxidante o antiinflamatoriao ${ }^{37,38}$, sin embargo, en un estado hipóxico se produce una depleción de la tetrahidrobiopterina (BH4) cofactor de vital importancia para la función de esta enzima. Esta ausencia produce un desacoplamiento de la ruta que genera una producción de superóxido en lugar de $\mathrm{NO}^{39}$.

Toda esta generación de ROS a través de estos sistemas se acumula en el citoplasma de la célula. En esta situación la célula entra en un metabolismo anaerobio, por lo que existe poco ATP y por lo tanto tampoco puede sintetizar proteínas de carácter antioxidante. Además, se produce un desequilibrio iónico en la membrana por lo que aumenta el pH dentro de la célula. La suma de estos procesos puede dar lugar a posteriores procesos de muerte celular (Fig2) que se explican a continuación.

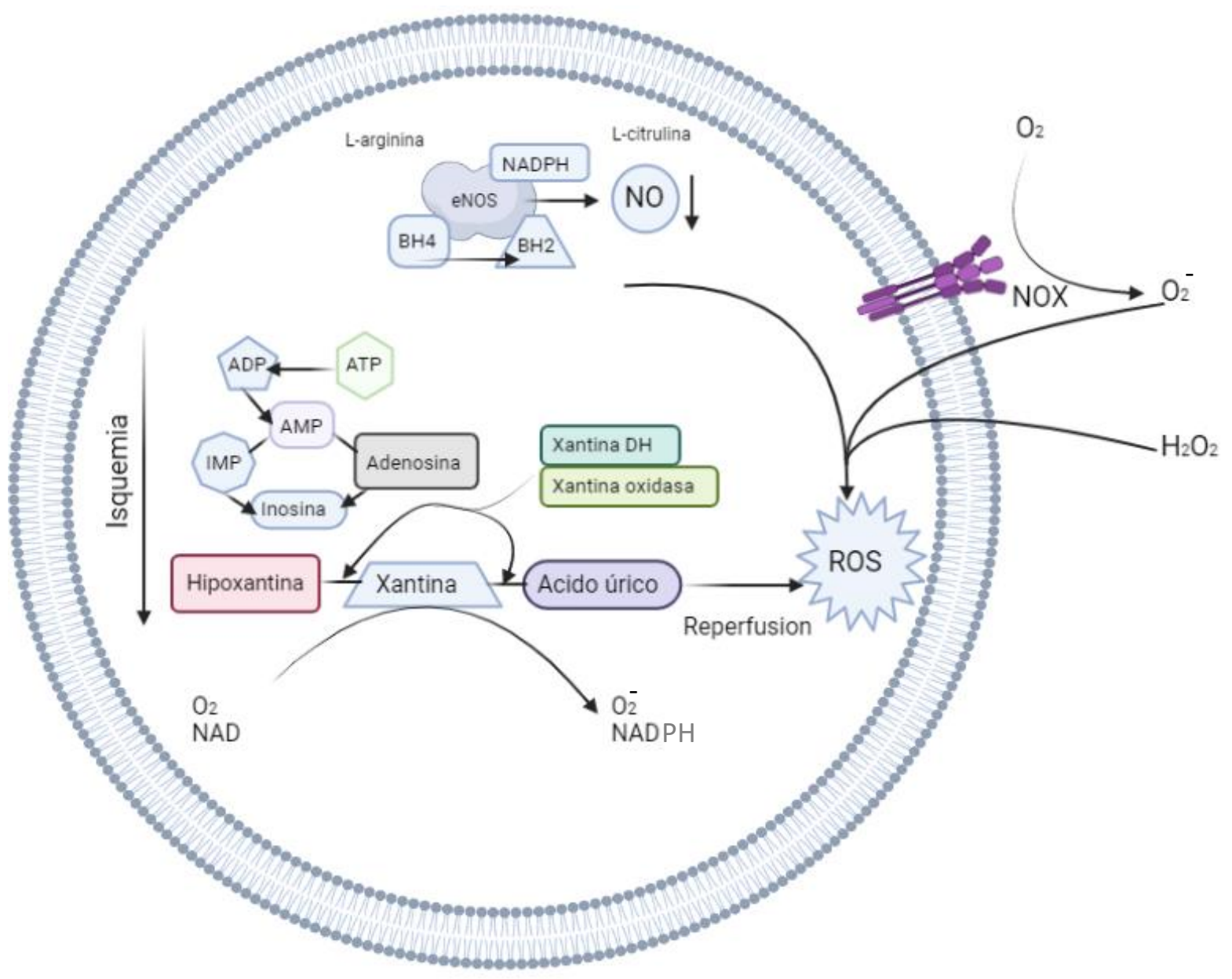


Figura 2: Resumen de los mecanismos de generación enzimática de ROS. En esta imagen se resumen los mecanismos de la NO sintasa, Xantina oxidasa y NADPH oxidasa. Imagen adaptada de Current Mechanistic Concepts in Ischemia and Reperfusion Injury. 1650-1667 (2018) doi:10.1159/000489241.

- Mecanismos de apoptosis

La apoptosis es un proceso de muerte celular activado por la propia célula cuando esta se encuentra en condiciones de estrés. En este caso la apoptosis ocurre como consecuencia del estrés hipóxico que produce la isquemia en las células debido al aumento de $\operatorname{ROS}^{40}$. Existen dos vías principales de apoptosis, la vía extrínseca, en la cual la vía de señalización se activa a través de ligandos de muerte como puede ser Fas ligando, TNF- $\alpha$ o TRAIL. Estos ligandos activan la proteasa caspasa 8 que a su vez produce un procesamiento de la caspasa 3 que es la que induce la apoptosis. La vía intrínseca se activa a través en cambios en la integridad de la membrana mitocondrial, estos cambios pueden producirse debido a estímulos como hipoxia, radiación o toxinas celulares. Este cambio de integridad de la membrana afecta a las proteínas proapoptóticas de la familia de Bcl-2. En el daño por isquemia la proteína Bad que se encuentra en el citoplasma une a Bcl-2. En paralelo Bax y Bak se procesan e insertan en la membrana mitocondrial y producen una liberación de proteínas pro-apoptóticas como Smac/Diablo, HTRA2/Omi etc ${ }^{41-43}$.

- Autofagia

La autofagia es un proceso celular a nivel evolutivo altamente conservado que se encarga de la degradación de proteínas y orgánulos en exceso o disfuncionales. En este proceso los contenidos citoplasmáticos de la célula se contienen dentro de una doble membrana llamada autofagosoma que es derivada a los lisosomas donde posteriormente se produce la degradación. Este proceso ocurre de manera natural en la mayoría de las células ${ }^{44}$. Se ha descrito que en una primera etapa de isquemia no se inducen procesos de autofagia aunque el número de fagosomas se ve aumentada, sin embargo, si esta se prolonga demasiado se puede apreciar un aumento de la autofagia así como de lisosomas disfuncionales durante la reperfusión lo cual sugiere una afectación en la vía de degradación lisosomal. La autofagia ha demostrado ser una vía de alta importancia para la recuperación celular y, deficiencias en los procesos de autofagia, han demostrado estar asociados con una gran cantidad de patologías cardiacas como puede ser hipertrofia cardiaca o cardiomiopatias ${ }^{45-47}$. 


\section{- Necrosis}

Se trata de un proceso de muerte celular, sin embargo, en contraposición con la apoptosis la necrosis se caracteriza por la permeabilización de la membrana y la destrucción de los orgánulos. La necrosis aparece cuando existe un estrés externo excesivo y al contrario que la apoptosis, se considera un proceso pasivo y no regulado $^{48}$. Este proceso ocurre en los primeros minutos de la reperfusión cuando los cardiomiocitos no tienen un balance correcto de iones, esto da lugar a la ruptura de la membrana celular y la liberación del contenido celular a la matriz extracelular, que genera unos patrones histológicos muy característicos llamados bandas de necrosis. A su vez, también se producen ruptura del sarcolema, depósitos masivos de $\mathrm{Ca}^{++}$en la matriz extracelular y desorganización de las miofibrillas sarcoméricas ${ }^{49}$.
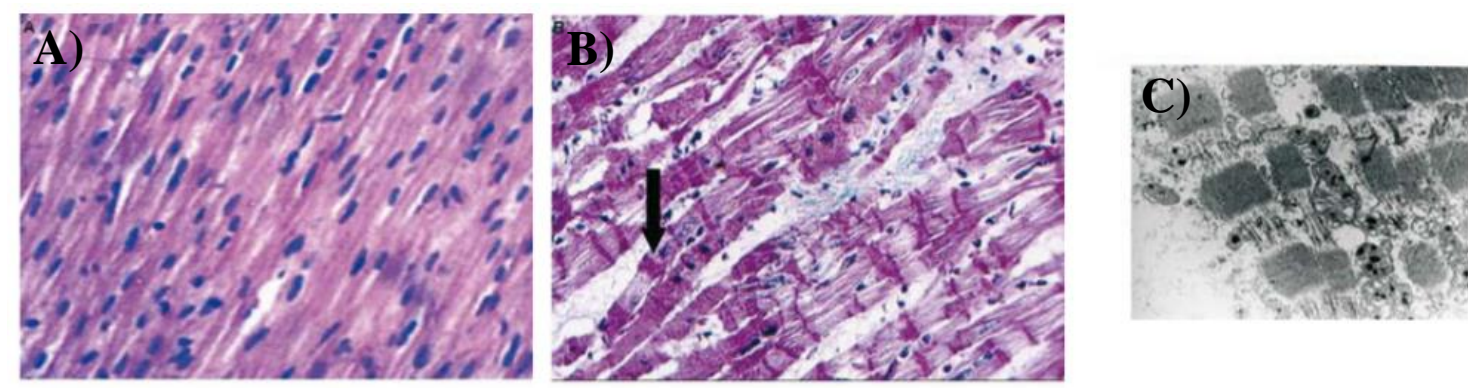

Figura 3: A) Imagen histológica de miocardio porcino en condiciones normales. B) Imagen histológica de miocardio porcino sometido a 50 minutos de isquemia seguido de reperfusión. C) Imagen de microscopia electrónica donde se puede apreciar acúmulos de proteínas sarcoméricas y disrupción mitocondrial. Imagen obtenida de: Ruiz-meana, M. \& García-dorado, D. Pathophysiology of IschemiaReperfusion Injury : New Therapeutic Options for Acute Myocardial Infarction

\subsubsection{Patología asociada al daño por isquemia/reperfusion}

El daño por reperfusión además genera una serie de lesiones típicas se enumeran a continuación.

- Arritmias: Entre las arritmias más comunes derivadas del daño por reperfusión se encuentran los ritmos idioventriculares, taquicardia ventricular $\mathrm{y}$ fibrilación ${ }^{50,51}$.

- Aturdimiento miocárdico o Myocardial "stunning". Se trata de un proceso reversible que ocurre en la reperfusión aguda isquémica en la que se puede dar una disfunción de la contractilidad cardiaca de naturaleza reversible. Esto se debe a la sobrecarga de $\mathrm{Ca}^{2+}$ en el miocardio ${ }^{52}$. 
- Obstrucción microvascular y hemorragia intramiocárdica: La oclusión de las células endoteliales puede deberse a múltiples factores como puede ser la embolización de debris, la liberación de sustancias vasoconstrictoras o trombo génicas o colapsos estructurales de los capilares. La obstrucción microvascular se asocia además con unas mayores áreas de infarto, así como una peor fracción de eyección ventricular después del infarto ${ }^{53,54}$.

\subsubsection{Tratamiento para el daño por isquemia reperfusión}

Si bien es cierto que el daño por isquemia reperfusión ocurre en mayor medida a un nivel local, también se ha descrito que diversas moléculas derivadas del tejido isquémico pueden entrar en la circulación sistémica y afectar a otros órganos pudiendo dar lugar a una inflamación sistémica. A continuación, se describe una serie de estrategias actuales que se usan en la medicina contemporánea para intentar paliar o reducir el daño miocárdico producido por todos los mecanismos previamente descritos.

-Tratamientos Actuales

La primera línea de actuación frente a un problema isquémico se basa en la restauración del flujo sanguíneo sobre la zona infartada. Para ello destacan dos técnicas que son las principalmente usadas en estas ocasiones destinadas a la eliminación de la obstrucción, en uno de los casos se trata de una disolución química del trombo mediante el tratamiento con agentes trombolíticos, mientras que el otro tratamiento se basa en una inyección percutánea introduciendo un stent para abrir mecánicamente la oclusión. Dependiendo de las circunstancias se utiliza un tratamiento $\mathrm{u}$ otro tratamiento, en general se prefiere la inyección percutánea (PCI) si se prevé que se puede realizar la operación en menos de 90 minutos, mientras que si el paciente se encuentra en una localización sin capacidad para realizar PCIs y se prevé un tratamiento más tardío, se opta por los trombolíticos. En el caso de optar por la PCI los pacientes deben tomar de manera inmediata una aspirina entre $160 \mathrm{mg}$ y $325 \mathrm{mg}$, además de una suplementación de oxígeno si la saturación de baja por debajo del $91 \%$. Antes de realizar el PCI los pacientes deben haber recibido agentes antiplaquetarios como heparina intravenosa y P2Y2 inhibidor(ticagrelor) ${ }^{55-57}$.También se ha demostrado que el tratamiento posterior al PCI con ciertos fármacos como pyridoxal5 -phosphate monohydrate (MC-1) reducen la necrosis cardiaca ${ }^{58}$. 
-Tratamientos en desarrollo

Además de estos tratamientos de primera línea, se hayan en estudio diferentes enfoques para tratar el daño que produce la reperfusión. Aunque los tratamientos previamente descritos han demostrado su efectividad para tratar el daño isquémico, estos pacientes todavía sufren una patología asociada al daño sufrido durante el periodo isquémico junto con el daño durante la reperfusión. Los modelos actuales que tenemos no son lo suficientemente complejos como para modelizar completamente todos los mecanismos por los cuales se genera este tipo de daño, lo cual dificulta en gran medida la búsqueda de agentes terapéuticos para esta patología, siendo necesario el uso de modelos animales. Estos modelos a su vez también generan variabilidad dependiendo del animal que utilicemos, sin embargo, se han desarrollado algunas terapias gracias a los experimentos llevados a cabo en este tipo de modelos. Algunos ejemplos de terapia para disminuir el daño por isquemia reperfusión se centran en generar una hipotermia sistémica entre $32-34^{\circ} \mathrm{C}$ al principio del periodo isquémico manteniéndose durante la reperfusión. Este tratamiento ha demostrado generar una cardioprotección adecuada en modelos animales de conejo y cerdo ${ }^{59-62}$. En los ensayos clínicos GUARDIAN (Guard During Ischemia Against Necrosis) se estudiaron 11.000 pacientes con síndrome coronario agudo que recibieron un inhibidor de la bomba $\mathrm{Na} / \mathrm{H}$ (cariporida). Como hemos visto en el periodo isquémico se produce una sobrecarga de sodio en la membrana debido a la actividad de la bomba $\mathrm{Na} / \mathrm{H}$ por lo que se decidió inhibir la misma con la cariporida. Los pacientes que recibieron la dosis más alta de cariporida antes del episodio isquémico mostraron cierta protección frente a la isquemia sin efectos en otros parámetros ${ }^{63-65}$. Se postula que el efecto de la cariporida no se centraría en evitar la acidosis si no en retrasar la depleción de las reservas de energía de la célula y por tanto el rigor en la contracción que se produce en la isquemia ${ }^{66,67}$. 


\subsubsection{Cardiotoxicidad derivada de antraciclinas}

Las antraciclinas son una serie de drogas utilizadas en el ámbito de la medicina para tratar un amplio rango de tumores y hoy en día juegan un papel realmente importante en canceres sólidos o hematológicos. Esta familia de drogas descubiertas en 1950 a partir de la bacteria Streptomyces peucetius han sido utilizadas en combinación con otros agentes quimioterapéuticos en gran cantidad de patologías como linfoma, sarcoma cáncer de mama y leucemia. Sin embargo, con los descubrimientos de las disfunciones de ventrículo izquierdo e IC que producían se empezó a incluir medidas de seguridad cardiaca para este tipo de pacientes como puede ser limitación de la dosis, revisiones periódicas de la función cardiaca etc ${ }^{68,69}$. El riesgo de sufrir una IC dependiente de antraciclinas se incrementa de manera directamente proporcional a la dosis acumulada administrada, en torno a un 3-5\% para una dosis de $400 \mathrm{mg} / \mathrm{m}^{2}$ y aumenta hasta valores de $18-48 \%$ para dosis de $700 \mathrm{mg} / \mathrm{m}^{2}$. Estos valores generales además se encuentran afectados por otra serie de factores, por ejemplo los pacientes de menos de 5 años así como los mayores de 65 tienen un riesgo incrementado de sufrir procesos de cardiotoxicidad ${ }^{70-72}$.

La cardiotoxicidad mediada por antraciclinas se divide a su vez en diferentes tipos, por un lado, tenemos la cardiotoxicidad aguda que ocurre durante las 2 semanas posteriores al tratamiento, la crónica de aparición temprana, aquella que aparece durante el primer año del tratamiento, y la crónica de aparición tardía en la que los síntomas aparecen después de un año de tratamiento. La definición de cardiotoxicidad se estableció en primera instancia como la aparición de un descenso del 10\% en la FEVI quedando por debajo del $50 \%{ }^{73}$ aunque de manera más reciente se ha establecido como un descenso de más de un $10 \%$ alcanzando valores por debajo de un $53 \%{ }^{74}$. Debido a la tardía aparición de este tipo de patología que suele ocurrir de manera asintomática es de vital importancia la detección de posibles eventos de cardiotoxicidad. Para ello se utilizan las siguientes técnicas ${ }^{75}$.

\subsubsection{Detección de Cardiotoxicidad}

\section{- Troponina I}

La Troponina I (TnI) es una proteína que se encuentra exclusivamente en las células miocárdicas. Una elevación de la TnI en plasma es señal de que se ha producido un daño cardiaco de algún tipo y esta TnI está siendo liberada por las células del miocardio al torrente sanguíneo. Estas elevaciones de la TnI pueden ser señal también de daños cardiacos menores lo cual lo hace un marcador diagnóstico y pronóstico bastante 
sensible $^{76}$. Ciertos estudios han demostrado que la TnI aumenta rápidamente en aproximadamente el 33\% de los pacientes tratados con una alta dosis de quimioterapia. Estos incrementos en la TnI a su vez se asocian con una reducción de la FEVI durante el siguiente año ${ }^{77,78}$.

- Péptido Natriurético N-Terminal tipo pro B

Los péptidos natriuréticos son producidos y liberados por los miocitos cardiacos del corazón. En condiciones normales los pacientes tienen concentraciones séricas de este péptido insignificante, sin embargo, cuando se produce alguna alteración cardiaca relacionada con la volemia o el aumento de precarga y postcarga estos son liberados por los miocitos aumentando su concentración sérica ${ }^{79}$. A su vez esta molécula puede servir como seguimiento de eventos cardiotóxicos ya que elevaciones por encima de un nivel basal, que generalmente suelen ocurrir después de cada ciclo de quimioterapia, pueden ser la señal de que se está produciendo un daño cardiaco ${ }^{80,81}$. Su uso se encuentra ampliamente estudiado, en una cohorte de 205 niños tratados con antraciclinas para una leucemia aguda la elevación de del péptido natriurético $\mathrm{B}$ durante los primeros 90 días de quimioterapia sirvió como predictor de cardiotoxicidad a un tiempo total de 4 años ${ }^{82}$.En otro estudio se comprobó que la medición del péptido natriurético antes y después de cada ciclo durante toda la terapia predijo la cardiotoxicidad de 109 pacientes con sarcoma primario y linfoma ${ }^{81}$.

- Pruebas de imagen

Dentro de las pruebas de imagen la más ampliamente utilizada es la ecocardiografía, tanto a nivel de seguimiento, así como durante el tratamiento quimioterapéutico. Se trata de una prueba con una gran repetibilidad y disponibilidad, a su vez esta prueba no entraña ningún tipo de exposición a radiación al paciente. La ecocardiografía permite la medición de las dimensiones del ventrículo izquierdo (VI) así como el ventrículo derecho (VD) y las funciones diastólica y sistólica durante un estrés o reposo. La ecocardiografía también permite la evaluación de las válvulas cardiacas, la aorta o el pericardio ${ }^{83}$. Existen también otro tipo de pruebas como el MUGA (multiunit gated analysis), que son altamente reproducibles pero no suelen usarse ya que no da más información aparte del cálculo de la FEVI y supone irradiar al paciente ${ }^{74,75}$.

\subsubsection{Mecanismos de cardiotoxicidad}

Aunque se encuentra bastante descrito que la acumulación de doxorrubicina induce cardiotoxicidad debido a una aparición excesiva de ROS, aun no se encuentran totalmente descritos todos los mecanismos de acción de este fenómeno ${ }^{84}$. 
Las antraciclinas inducen daño en la membrana celular vía peroxidación lipídica en todos los tejidos incluyendo el corazón. A su vez también se produce la reacción no enzimática de $\mathrm{Fe}^{3+} \mathrm{a} \mathrm{Fe}^{2+85,86}$. Esta generación de ROS ocurre además a través de varias vías como puede ser la inducción de la óxido nítrico sintasa, formación de peroxinitritos etc. Las vías de SAPKs JNK y p38 son activadas bajo los estímulos de estrés celular y se correlaciona con la apoptosis de los miocitos ${ }^{87-89}$.Otro factor que puede ser determinante es la inducción por parte de las antraciclinas de la disrupción sarcomérica. Una exposición a antraciclinas puede afectar a una aceleración de la degradación del titin mediante la vía de las calpaínas. El titin sirve como soporte para el ensamblaje de las proteínas filamentosas en los sarcómeros y su integridad es vital para la regulación de la función contráctil. Además, las antraciclinas producen una supresión de la síntesis de las proteínas del sarcómero pudiendo producir una sarcopenia típica de corazones con $\mathrm{IC}^{90,91}$.

Aunque la generación de ROS se plantea como la hipótesis más fundamentada en cuanto a la generación de daño ${ }^{92,93}$ también se han estudiado otros mecanismos como puede ser la acción de la topoisomerasa 2. La topoisomerasa $2 \beta$ es una enzima cuya función se centra para la transcripción, replicación y recombinación celular. Esta enzima cuando entra en contacto con las antraciclinas queda bloqueada lo que provoca la ruptura del DNA de cadena doble. Este suceso conlleva la activación de la vía de la apoptosis mediante $\mathrm{p} 53^{94-96}$. De hecho existen terapias como el dexrazoxano que actúan a nivel de evitar la interacción de las antraciclinas con la topoisomerasa $2^{97}$.
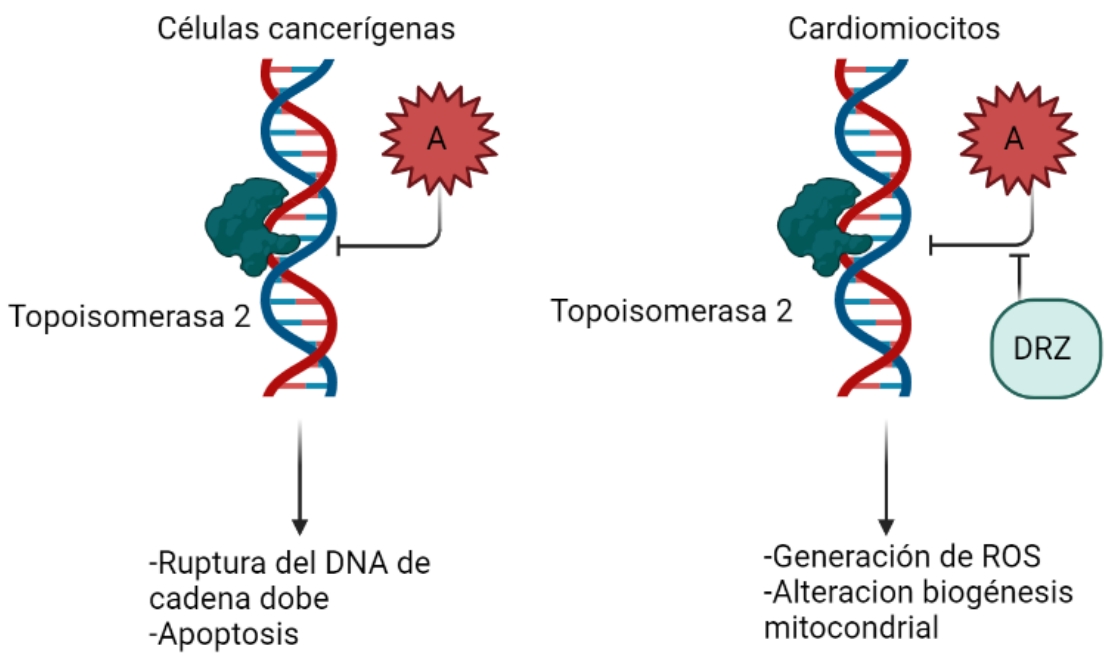

Figura 4: Figura resumen del mecanismo de cardiotoxicidad basado en la topoisomerasa II. En ella podemos ver que las moléculas de antraciclinas (A) se unen a la topoisomerasa II impidiendo su funcionamiento y por lo tanto la replicación celular. El dexrazoxano (DRZ) actúa como terapia inhibiendo la unión de las antraciclinas a la topoisomerasa. Imagen adaptada de : Anthracycline cardiotoxicity: an update on mechanisms, monitoring and prevention. Heart 104, 971 LP - 977 (2018). 
Es de vital importancia también señalar que, durante la cardiomiopatía derivada de doxorrubicina, se produce una fibrosis intersticial en el corazón. Aunque la doxorrubicina inhibe la transcripción de colágenos en las células tumorales, el tratamiento con doxorrubicina aumenta la deposición de este en el tejido cardiaco. Además, eleva la expresión de TGF- $\beta$ y promueve la señalización de diferenciación del fibroblasto hacia miofibroblasto (más pro-fibrótico). ${ }^{98-100}$

No podemos olvidar tampoco que la doxorrubicina induce una respuesta del sistema inmune. El tratamiento con doxorrubicina puede limitar la actividad de las células NK, estimular a respuesta de los linfocitos T-citotóxicos, así como reducir la capacidad de diferenciación de los macrófagos. Cabe destacar a su vez la importancia de los tolllike-receptors (TLRs). La cardiomiopatía inducida por la doxorrubicina se asocia con un incremento de TLR-2 que a su vez inducen la transcripción de NFkB dando lugar a la activación de los mecanismos de apoptosis ${ }^{101,102}$.

\subsubsection{Patología asociada al daño}

Todos estos mecanismos a nivel celular tienen como consecuencia una serie de síntomas que pueden aparecer en diferentes tiempos del tratamiento. Dependiendo de cuando se dan estos síntomas la patología se clasifica de diferentes maneras pudiendo identificar:

\section{-Complicaciones agudas}

Se da en un $0.4-41 \%$ de los pacientes tratados con antraciclinas y su aparición se encuentra ligada a la administración de la droga. En ella pueden ocurrir eventos de arritmias que en su mayoría son desapareamientos en la repolarización, disminución de voltaje en el complejo QRS, taquicardia etc. Estos síntomas no suelen conllevar problemas clínicos importantes y suelen revertirse con la cardioterapia adecuada 103 Menos de un $1 \%$ de los pacientes tratados con quimioterapia mueren por un ataque al corazón espontaneo después de la administración de estas drogas ${ }^{104,105}$.

-Complicaciones subagudas

Estas aparecen después de varias semanas después de la última dosis de antraciclinas. Este tipo de complicación es bastante inusual comparado con las reacciones agudas siendo su manifestación más común la pericarditis. 


\section{-Cardiotoxicidad crónica}

Se da como consecuencia de una exposición repetida de los cardiomiocitos a las antraciclinas y se da en el $0.4-23 \%$ de los pacientes tratados con estas drogas. Ocurre pasadas varias semanas o meses después de la quimioterapia y afecta generalmente al ventrículo izquierdo, aunque en raras ocasiones puede afectar a ambos. Los síntomas clínicos incluyen una disminución en la tolerancia al ejercicio, disnea de esfuerzo, cardiomegalia y disminución de la fracción de eyección del ventrículo izquierdo ${ }^{106}$. Aunque existe tratamiento farmacológico para este tipo de patología, este consiste en el tratamiento de las complicaciones que puedan derivar de la propia IC dando lugar a la muerte en un $27-61 \%$ de los pacientes. Se asocia peor pronóstico a aquellos pacientes que muestran síntomas en las primeras 4 semanas después del tratamiento mientras que en niños la mortalidad se encuentra en aproximadamente en un $20 \%{ }^{104}$.

\section{-Cardiotoxicidad tardía}

Se diagnostica pasados varios años después de completar los ciclos de quimioterapia tanto en niños como en adultos. En estos casos se manifiesta como una IC congestiva, presentando problemas de arritmias y conductividad que raramente dan lugar a la muerte por infarto. Las complicaciones a largo plazo pueden ocurrir como una disfunción sistólica o diastólica del ventrículo izquierdo generando variaciones en el grosor de la pared en relación con la edad del paciente. Este tipo de patología afecta a aproximadamente al $5 \%$ de los pacientes ${ }^{107,108}$.

\subsubsection{Tratamiento para el daño por antraciclinas}

A la hora del tratamiento no existe una línea específica para tratar la cardiotoxicidad mediada por antraciclinas y la decisión de tratar un cáncer con antraciclinas debe basarse en un potencial beneficio de este sobre la cardiotoxicidad que el tratamiento puede producir. Al ser una enfermedad en la que somos conocedores de que puede aparecer dichos episodios antes de que suceda es de vital importancia el hecho de intentar prevenir cualquier posible cardiopatía. Por ello los sanitarios recomiendan adoptar un estilo de vida que favorezca un buen estado de salud cardiaco así como ejercicio moderado o controlar los niveles de colesterol en sangre. En pacientes con algún tipo de cáncer que vaya a ser tratado con antraciclinas se recomienda llevar un seguimiento generalmente cada 3 meses por ecografía para evaluar si empieza a aparecer alguna afectación cardiaca, por ello el tratamiento contra la cardiotoxicidad 
se encuentra estrechamente ligado a las pruebas (generalmente de imagen) asociadas a la monitorización del paciente.

Al ser un efecto mediado en su mayor parte por la alta producción de radicales libres en los cardiomiocitos, muchas estrategias se encuentran orientadas a reducir estos niveles. Por ejemplo, una estrategia es la encapsulación de la doxorrubicina en liposoma PEGilados que da lugar a una reducción de la doxorrubicina que se encuentra libre por el organismo y por lo tanto en los cardiomiocitos ya que esta doxorrubicina encapsulada es captada de manera preferencial en las células tumorales ${ }^{109,110}$.

Uno de los mecanismos de generación de ROS se basa en la reacción de Fenton por la cual la doxorrubicina genera ROS a través de la oxidación de complejos de Fe. Por este motivo una de las estrategias para tratar la cardiotoxicidad que se está probando se basa en la quelación del hierro mediante el uso de dexrazoxano, por lo que su efecto beneficioso que se observa usando este fármaco puede ser por la inhibición de la unión de la doxorrubicina a la topoisomerasa 2 o por la quelación del propio Fe. Ciertos estudios muestran resultados prometedores usando este agente que es capaz de reducir la incidencia de la IC congestiva y evitar la reducción de la FEVI ${ }^{111,112}$.

A su vez existen otros estudios que abogan por el uso de drogas cardiovasculares como puede ser el uso de beta-bloqueantes o bloqueadores del receptor de angiotensina, sin embargo, su uso aún no se encuentra del todo demostrado. Existe un ensayo clínico randomizado usando carvedilol frente a placebo que encontró una reducción en la incidencia de reducción del FEVI del grupo del carvedilol frente al placebo ${ }^{113}$.

Otros estudios han demostrado a su vez que el uso de metoprolol y candesartan tienen cierto efecto cardioprotector en cáncer de mama tratadas con una dosis de antraciclinas de $240 \mathrm{mg} / \mathrm{m}^{2} 114$. 


\section{Terapia celular}

\subsection{Contexto histórico de la terapia celular}

La terapia celular se define como aquella en la cual material celular es inyectado en un paciente. Las tecnologías de terapia celular se están empezando a abrir paso en la práctica médica de manera importante en las últimas décadas como una posible herramienta terapéutica potente para tratar una gran serie de patologías.

Como primer hecho destacable en este campo, en 1963 el profesor James Till de la universidad de Toronto descubre colonias de células madre presentes en la médula ósea ${ }^{115}$. Solo dos años más tarde en 1965 se realiza el primer trasplante de células madre conjuntival autólogo por el doctor Jose Barraquer. En 1981 se desarrollan las primeras líneas de células madre derivadas de embriones de ratón, en las universidades de Cambridge y de California de manera independiente. En 1997 se autoriza por la FDA el primer tratamiento basado en células madre llamado Carticel ®. En 2006 se descubren las células madre pluripotentes inducidas por el profesor Shinya Yamanaka el cual recibiría el premio Nobel 6 años más tarde. En 2013 se describe la aplicación de los sistemas CRISPR-Cas9 como sistema de edición génica por varios grupos al mismo tiempo. Cabe destacar entre ellos la terapia basada en células desarrollada por la empresa TAKEDA para el tratamiento de fístulas perianales que actualmente se está comercializando en Europa después de haber superado los ensayos clínicos en fase III desde $2018{ }^{116,117}$. A partir de estos años los estudios y el interés general de los mercados se multiplico enormemente en este campo, los mercados globales vieron un crecimiento estimado de 6,6 billones de dólares durante los años 2012 a 2016 es decir un crecimiento mercantil de entorno al $11.7 \%$ al año en inversiones asociadas a la terapia celular. Sin embargo, recientes análisis demuestran que la mayoría de terapias basadas en células se encuentra en épocas tempranas de desarrollo (ensayos clínicos en fase I o II) generalmente enfocadas en la demostración de su seguridad. ${ }^{118}$

Actualmente la mayoría de las terapias celulares son aún experimentales con algunas excepciones como el trasplante de células hematopoyéticas (HSC) en cuyo caso se encuentra bastante bien establecido para enfermedades hematológicas, siendo el caso de las CAR-T cells el más paradigmático ${ }^{105,119-121}$. La terapia celular se basa tanto en la acción de una serie de células en un tejido ya sea para repararlo mediante la regeneración del propio tejido mediante la diferenciación de la célula inyectada, o mediante el efecto que pueda producir la célula en el nicho donde esta sea inyectada. 
El hecho de poder regenerar un tejido que se encuentra dañado o que no es capaz de funcionar de manera correcta mediante un trasplante celular coloca el foco de atención en tipos celulares que tengan un alto poder de multiplicación y de diferenciación ${ }^{117}$. Por este motivo el uso de células madre como fuente de experimentación se ha disparado en todo el mundo. Las células madre son un tipo celular genérico no diferenciado que tiene la capacidad de crear un número indefinido de copias de sí misma, así como generar células diferenciadas de varios tejidos del cuerpo. Este tipo de células se encuentra en seres multicelulares y son de vital importancia para el desarrollo, crecimiento y mantenimiento de los organismos ${ }^{122-124}$.

La nueva generación de terapia celular puede ser clasificada de muchas maneras diferentes $^{125}$, como por ejemplo si las células son administradas del mismo individuo (trasplante autólogo) o si vienen de un donante (alogénico) ${ }^{126}$. De acuerdo con su origen se pueden clasificar como embrionarias, fetales, infantiles (de cordón umbilical, y gelatina de Wharton) y adultas. A su vez estas células pueden dividirse en función de su capacidad de diferenciación ${ }^{127} 128$.

\subsection{Células MSC}

Este trabajo se encuentra centrado en el uso de las células estromales mesenquimales o MSCs, estas células, a pesar de tener una capacidad de diferenciarse a varios tipos celulares no se encuentran consideradas como células madre propiamente dichas, ya que para pertenecer a este tipo celular la célula debe poder autorrenovarse de manera perpetua cuando son inyectadas in vivo in vivo. Fueron descubiertas en humanos a partir de 1970 por Friedenstein y colaboradores siendo el primero en detallar su potencial diferenciador el doctor Pittenger ${ }^{129}$.Los criterios para definir una célula como MSC fueron descritos por primera vez por los doctores M. Dominici y EM Horwitz et al. entre el año 2005 y 2006 y se resumen en la Tabla $\mathbf{1}^{130,131}$. Se trata de células que son capaces de adherirse a plástico adquiriendo una morfología fibroblastoide ${ }^{132-134}$. Estas células tienen un gran potencial para la ingeniería de tejidos ya que son capaces de diferenciarse a varios tejidos y su aislamiento es relativamente fácil. Las células MSCs pueden diferenciarse a varias líneas celulares bajo determinadas condiciones in vitro y en limitadas situaciones cuando son trasplantadas in vivo. Debido a su origen heterogéneo es de vital importancia la identificación de la MSCs mediante una serie de marcadores de membrana para los cuales las MSCs deben ser positivos o negativos dependiendo del marcador. 


\begin{tabular}{|c|c|c|c|c|}
\hline Marcador & $\begin{array}{l}\text { Antigeno de } \\
\text { membrana }\end{array}$ & + & $+/-$ & - \\
\hline \multirow[t]{7}{*}{ Positivo } & Stro-1 & 7 & 1 & 2 \\
\hline & Cd13 & 5 & 0 & 0 \\
\hline & CD29 & 5 & 0 & 0 \\
\hline & CD44 & 11 & 0 & 1 \\
\hline & CD73 & 5 & 0 & 0 \\
\hline & CD105 & 7 & 0 & 0 \\
\hline & CD 106 & 4 & 0 & 2 \\
\hline \multirow[t]{5}{*}{ Negativo } & CD11b & 0 & 0 & 3 \\
\hline & CD31 & 0 & 3 & 10 \\
\hline & CD34 & 1 & 1 & 10 \\
\hline & CD45 & 0 & 0 & 11 \\
\hline & CD117 & 0 & 2 & 3 \\
\hline \multirow[t]{4}{*}{ Variable } & Sca-1 & 0 & 0 & 0 \\
\hline & CD10 & 6 & 0 & 5 \\
\hline & CD90 & 11 & 1 & 1 \\
\hline & Fik-1 & 2 & 1 & 1 \\
\hline
\end{tabular}

Tabla 1: Antígenos elegidos en al menos 4 poblaciones de MSCs en 19 artículos revisados. Los números indican poblaciones de MSCs aisladas de diferentes tejidos en los que se reporta si el marcador es positivo en la mayoría de células (+), si algunas de ellas son positivas (+/-) o negativo (-). Las MSCs estudiadas se han aislado de manera mayoritaria a partir de médula, aunque también hay usando como fuente, grasa, piel, timo, riñón, musculo, pulmón, hígado y placenta. Tabla adaptada del artículo: Minimal criteria for defining multipotent mesenchymal stromal cells. The International Society for Cellular Therapy position statement. Cytotherapy 8, 315-317 (2006).

Estas células a su vez han demostrado tener un alto potencial inmunomodulador. El aislamiento de MSCs puede ser realizado a partir de múltiples tejidos, aunque sin duda los más utilizados han sido los de médula ósea. Estos tipos celulares pueden cultivarse y multiplicarse de manera artificial para luego ser inyectados en los pacientes de manera autóloga y fácilmente escalable y segura para los pacientes ${ }^{135,136}$.

Estas células además han sido consideradas como muy seguras a la hora de usarlas como terapia celular, a lo largo de los últimos 25 años los procedimientos de inyección de MSCs han demostrado ser altamente seguros alcanzando los 950 ensayos clínicos 
usando las MSCs listados por la FDA. at www.clinicaltrials.gov y https://celltrials.org/public-cells-data/msc-trials-2011-2018/65) $)^{137}$.

\subsubsection{MSC en la terapia cardiaca}

Una de las primeras opciones que se barajaron en primera instancia era que las MSCs trasplantadas fueran capaces de diferenciarse a cardiomiocitos pudiendo así sustituir a aquellos que morían durante el infarto. Sin embargo estudios posteriores han demostrado que la diferenciación de una MSC a un cardiomiocitos es un suceso extremadamente raro y no podía ser responsable del efecto terapéutico que se producía cuando se inyectaban estas células en el músculo cardiaco infartado ${ }^{138,139}$.

Durante las dos últimas décadas se han llevado a cabo enormes esfuerzos para poder recuperar el tejido cardiaco dañado sin embargo, esto conlleva una serie de dificultades como son: la dificultad que entraña para un corazón adulto generar cardiomiocitos de novo, una limitada plasticidad celular y la tendencia a que se activen vías proinflamatorias y pro- fibróticas. Las MSCs se han considerado una opción atractiva para la terapia celular debido a su fácil aislamiento y su secreción de moléculas bioactivas, que pueden inducir la reparación de los tejidos y modular la respuesta inflamatoria. En caso de trasplantes alogénicos las MSCs han demostrado ser altamente seguras ya que carecen de complejo principal de histocompatibilidad (HLA) de clase II y a su respuesta inmunomoduladora ${ }^{140-142}$.

Generalmente las terapias basadas en inyección de MSCs suelen utilizar una cantidad de aproximadamente unos 100 millones de células, lo cual no es suficiente para generar un reemplazo de la zona dañada pero si para observar un efecto terapéutico de estas células en la zona ${ }^{143}$.Cuando las MSCs son inyectadas después de un infarto muy pocas de ellas son capaces de quedarse en la zona dañada y apenas un $1 \%$ de estas células se puede detectar más tarde. Sin embargo, aunque la capacidad de permanecer en el tejido y reemplazarlo sea pequeña el efecto paracrino de estas células es suficiente como para ser terapéutico. Diversos experimentos han demostrado que las MSCs son capaces de liberar factores anti inflamatorios que son capaces de interaccionar con las células endógenos o mejorar su fisiología ${ }^{144-146}$. A su vez, son capaces de mejorar el proceso de reparación en modelos porcinos mediante una estimulación del ciclo celular de los cardiomiocitos.

Debido a su alto potencial existen varios ensayos clínicos que han superado la etapa preclínica y se encuentran en estado de fase clínica. En el estudio TRIDENT 
(Transendocardial Stem Cell Injection Delivery Effects on Neomyogenesis Study) ${ }^{147}$ se compararon los efectos de dos dosis de MSCs derivadas de médula ósea, 20 y 100 millones. El estudio además de asegurar la seguridad de ambas dosis de células demostró que las que recibieron la dosis alta de células de médula ósea mostraron una reducción de la cicatriz cardiaca, así como una mejora en la FEVI.

En otro estudio MSC-HF (Autologous Mesenchymal Stromal Cell Therapy in Heart Failure ${ }^{148}$ se demostró que inyecciones repetidas de stem cell mejoran los índices de remodelado cardiaco. En este estudio se alcanzaban mejores resultados de manera proporcional a la cantidad de células inyectadas hasta un máximo de 20 inyecciones, lo cual puede sugerir que existe un límite superior en la dosis de células utilizadas.

Otro estudio utilizando MSCs derivadas de tejido adiposo fueron utilizadas para ser inyectadas en el estudio PRECISE (A Randomized Clinicla Trial of Adipose-Derived Stem and Regenerative Cells in the Tratment of Patientes With Non Revacularizable Ischemic Myocardium). Este estudio randomizado, y doble ciego muestra una mejora en la función ventricular, perfusión miocárdica y capacidad de hacer ejercicio en los pacientes que recibieron las células ${ }^{149}$.

En el estudio PROMETHEUS (The Prospective Randomized Study of Mesenchymal Stem Cell Therapy in Patients Undergoing Cardiac Surgery) se demuestra que inyecciones intramiocardicas de MSCs autólogas en 6 pacientes con un bypass coronario mejoraron en su fracción de eyección. Estos pacientes también mostraron una menor cicatriz cardiaca ${ }^{150}$

En el estudio POSEIDON se compara la eficacia y seguridad de las células autólogas frente a las alogénicas. Estas células se inyectan de manera intracardiaca mediante un catéter. Los resultados muestran que ambas células son igualmente seguras y ambos grupos aumentaron su fracción de eyección teniendo incluso mejores resultados en promedio los trasplantes de células alogénicas ${ }^{151}$.

También se encuentra en fase clínica el estudio MyStromaCell (Mesnechymal Stromal Cell Therapy in Patients With Chronic Myocardial Ischemia) en el cual las MSCs son tratadas previamente con VEGF-A165 y posteriormente inyectadas en los pacientes. Los pacientes que recibieron las MSCs previamente tratadas mostraron un capacidad de hacer ejercicio significativamente superior al grupo control ${ }^{152}$.

Sin embargo, a pesar de estos prometedores resultados la mayoría de ensayos clínicos y preclínicos han demostrado no tener la efectividad que se esperaba. Este tipo de terapia supone un avance en el campo ya que empieza a ofrecer una opción terapéutica 
cuando las técnicas usuales de revascularización han fallado. Hasta la fecha todavía quedan muchas incógnitas en los mecanismos terapéuticos de las MSCs en la regeneración cardiaca. Las dosis adecuadas de células, la llegada de las células a la zona a afectada y hacer que permanezcan en este lugar o la muerte al inyectar de la mayoría de las células son aspectos que deben ser solucionados antes de poder considerar a las MSCs como una terapia para ser usada a gran escala en pacientes con afectación cardiaca. ${ }^{141}$

\section{Vesículas extracelulares (EVs)}

\subsection{Definición de vesículas extracelulares}

Las EVs son un grupo heterogéneo de vesículas de diferentes tamaños compuestas por una bicapa lipídica producidas tanto por células eucariotas como por células procariotas. Estas membranas lipídicas cuentan a su vez con proteínas que se encuentra o bien embebidas en ella (entre las que se encuentran receptores de membrana), o en su interior como proteasas y nucleasas. Se encuentra también demostrado que las EVs pueden contener en su interior proteínas, lípidos y ácidos ribonucleicos como pueden ser mRNA, miRNA trRNA etc ${ }^{153}$. Estas vesículas fueron descritas por primera vez por Pan JohnStone et al. en 1983 como un mecanismo propio de las células para descartar el material no deseado que se encontraba en su interior. Las vesículas conocidas como cuerpos apoptóticos fueron descubiertas alrededor de $2004^{154}$ y no es hasta hace unos pocos años que se ha descubierto que las células perfectamente sanas son capaces de liberar vesículas a partir de su membrana plasmática. Con investigaciones posteriores se ha determinado que estas vesículas tienen un papel realmente importante a la hora de la comunicación intercelular ya sea en condiciones fisiológicas o patológicas ${ }^{155}$.En cuanto a la nomenclatura, según las guías realizadas en el congreso MISEV 2018 de vesículas extracelulares, las vesículas extracelulares se consideran todas aquellas partículas de doble membrana liberadas por una célula sin capacidad replicativa. Debido a que no existen marcadores claros que determinen si las vesículas son de origen endosomal (exosomas) o derivados de la membrana plasmática (ectosomas) se pueden clasificar en función de su tamaño, composición o célula de origen ${ }^{156}$.

Las EVs se encuentran presentes en prácticamente todos los fluidos biológicos del cuerpo, como puede ser sangre, orina, semen, bilis fluido ascítico, leche materna etc. Estas vesículas son secretadas por las células de todos los tejidos ya sea en condiciones 
sanas o patológicas siendo su contenido por lo tanto dependiente de la célula progenitora.

\subsection{Biogénesis y liberación de partículas}

En función de su origen y tamaño las EVs se subdividen en una gran cantidad de grupos como pueden ser microvesículas, exosomas, cuerpos apoptóticos etc. Muchas de las fuentes literarias tienden a confundir las vesículas extracelulares con los exosomas siendo la principal diferencia que las vesículas extracelulares son aquellas que se forman a partir directamente de la membrana celular mientras que los exosomas se forman a partir de una invaginación de la membrana conocida como endosoma temprano que posteriormente da lugar al endosoma multivesicular que puede degradarse por medio de los lisosomas o liberarse al medio extracelular mediante una fusión de este último con la membrana plasmática. El término exosoma se empieza a utilizar para este tipo de partícula liberada a partir del endosoma multivesicular con un tamaño aproximado de 40-100nm ${ }^{157}$

El contenido de estas partículas extracelulares ha sido fuertemente estudiado en los últimos años, siendo la célula de origen la mayor influencia en su contenido. Sin embargo, existen proteínas de membrana que se sabe que se encuentran enriquecidas en los dominios de membrana en los cuales se forman estos endosomas. Esta familia en cuestión, denominada familia de las tetraspaninas como CD63, CD81,CD 82, CD9 etc fueron por primera vez identificadas en exosomas de células B donde estas proteínas estaban enriquecidas alrededor de 100 veces (relativo al receptor de transferrina). ${ }^{158}$

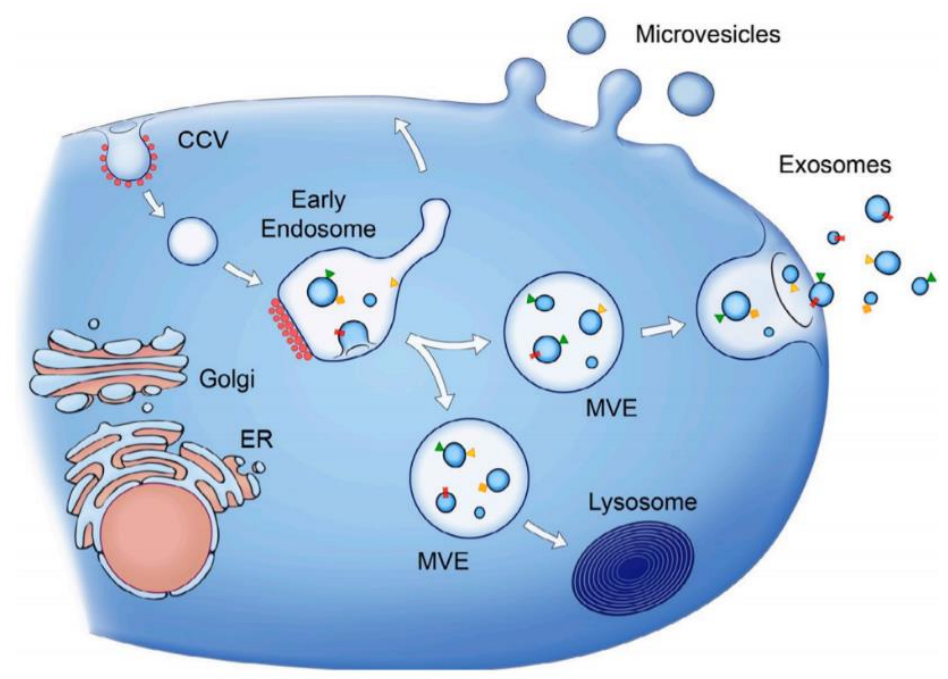


Figura 5: Figura resumen de los mecanismos de biogénesis de microvesículas y exosomas. Como se observa en la figura los exosomas se origina a partir de la maduración del endosoma temprano (Early Endosome) a un cuerpo multivesicular (Multivesicular Body) que finalmente se libera en la membrana, mientras que las microvesículas se generan a partir de la propia membrana celular. Imagen del artículo Extracellular vesicles: Exosomes, microvesicles, and friends. J. Cell Biol. 200, 373 LP - 383 (2013).

En cuanto a su composición lipídica los exosomas se encuentran enriquecidos en esfingomielina, gangliósidos y lípidos de-saturados. También se ha encontrado una mayor cantidad de fosfatidil-serina en los ácidos grasos de los exosomas lo cual podría facilitar su entrada en células receptoras, mientras que el incremento en esfingomilina y lípidos de-saturados respecto a una membrana celular normal podría implicar una mayor rigidez en su estructura ${ }^{159}$.

En cuanto a RNA se ha detectado que en torno al 15\% del RNA en EVs se trata de miRNA y tRNA, pudiendo contener a su vez RNA codificante y no codificante. La cantidad de RNA que contienen es relativa y depende fuertemente de la célula de origen. Debido a que existen ciertas especies de RNA que se encuentran especialmente enriquecidas en las EVs se cree que existe un mecanismo selectivo de internalización de RNA en las EVs, por ejemplo una secuencia con un motivo "CUGCC" en el extremo 3' junto con un sitio de unión para el miRNA $1289{ }^{160}$

\subsection{Métodos de aislamiento y caracterización}

Actualmente se usan de manera mayoritaria 3 métodos de aislamiento de vesículas enumeradas a continuación:

-Ultracentrifugación

Es el método más común de aislamiento de vesículas y se basa en la separación de estas en función de su gradiente de densidad al ser centrifugadas. En primera instancia las partículas con mayor densidad precipitan como pueden ser células, debris celulares, cuerpos apoptóticos, biopolímeros etc. Estas primeras centrifugaciones se realizan en torno a 2000xg para retirar los debris celulares y a $10.000 \mathrm{~g}$ para retirar los cuerpos apoptóticos de menor densidad. Seguidamente a este se suele acompañar de una centrifugación destinada a recuperar las vesículas en torno a $100.000 \mu \mathrm{g}$ durante unas 2 horas seguida de una exclusión por tamaño utilizando filtros de un poro entre 0.1 y $0.45 \mu \mathrm{M}$. Actualmente existe gran controversia y diferentes protocolos para aislar las vesículas por ultracentrifugación para adaptar la muestra a la eficiencia de aislamiento ya que 
factores como la aceleración, el tipo de rotor o la viscosidad de la muestra pueden afectar de manera importante al protocolo de aislamiento ${ }^{153,161}$.

La presencia de agregados proteicos, cuerpos apoptóticos y otras partículas no exosomales en el producto obtenido de la ultracentrifugación es una de las principales desventajas de este protocolo, por ello a veces se recurre a un gradiente de densidad en la ultracentrifugación para evitar esto. Pueden darse un gradiente constante de densidad o un gradiente en capas (gradiente de sacarosa u otros compuestos como puede ser iohexol, o iodixanol ${ }^{162}{ }^{163}$ ). Mediante estos métodos las banda que contiene los exosomas se encuentra en aquella que tenga una densidad de en torno a $1.1-1.19 \mathrm{~g} / \mathrm{mL}$ dependiendo del contenido de las vesículas ${ }^{164}$.

\section{-Filtración}

La filtración a su vez se puede dividir en muchos subtipos en función del tamaño de partícula que son capaces de separar

- Ultrafiltración: constan de membranas con filtros cuyos diámetros se encuentran entre 0.8 y 0.1 um. Este tipo de métodos generalmente se complementa añadiendo algún paso de centrifugación, aunque también existen muchos protocolos que usan simplemente este proceso para el aislamiento. Aunque se intenta utilizar membranas a las que no se adhieran las EVs es cierto que existe cierto porcentaje de ellas que son capaces de adherirse. Para evitar esto se pueden usar de manera complementaria métodos de vacío, presión o cromatografía de exclusión por tamaño ${ }^{165}$ que ayuden a separar estas vesículas, sin embargo, existe controversia en este punto ya que esta presión asociada puede ser capaz de generar deformaciones o afectar a la morfología de la vesículas ${ }^{166,167 .}$

- Diálisis de filtración hidrostática: En este tipo de protocolos nos permite aislar vesículas de disoluciones que se encuentren altamente diluidas. Este método es generalmente utilizado para obtener EVs de biofluidos diluidos como puede ser orina ${ }^{168,169}$. Las muestras son previamente sometidas a una centrifugación a 2000 g para eliminar el debris celular, seguidamente el sobrenadante se pone en contacto con una membrana de diálisis con un tamaño de poro de aproximadamente $1.000 \mathrm{kDa}$. Este proceso hace que las partículas con un peso mayor de $1.000 \mathrm{kDa}$ pasen a través de la membrana, después de 
este procesos se suele acompañar una ultracentrifugación para aislar y concentrar las vesículas ${ }^{161}$.

-Métodos basados en agregación de EVs o cambios en su solubilidad

-Precipitación usando polímeros hidrofóbicos, uno de los métodos más populares a la hora de extraer vesículas extracelulares, generalmente usando soluciones derivadas del polietilenglicol (PGE) que permiten un decrecimiento en la solubilidad de las vesículas debido al carácter super-hidrofílico de los polímeros. Esto permite el aislamiento con una centrifugación a baja velocidad (1500 g), por este motivo y su relativa sencillez a la hora de ejecutar el protocolo hace que sea uno de los métodos más utilizados, sin embargo sus principales desventajas radican en la contaminación variable que podemos encontrar en las muestras ya sea con proteínas, complejos proteicos, lipoproteínas, partículas virales etc ${ }^{170} 171$.

-Precipitación con Acetato Sódico: Este método se basa en la neutralización de las cargas negativas por parte de la fosfatidil serina en la superficie de las EVs por medio de acetato de sodio. Esto impide la hidratación de las vesículas extracelulares ya que la carga negativa de estas ha sido compensada y empieza a agregarse y a precipitar debido a interacciones hidrofóbicas. ${ }^{172}$

-Precipitación mediante métodos de afinidad

-Anticuerpos anti-EVs: Debido a que las EVs suelen estar enriquecidas en una serie de proteínas o receptores de membrana (como pueden ser las tetraspaninas, MHCo HSP) una de las estrategias que se barajan puede ser unir anticuerpos capaces de reconocer estas proteínas a alguna estructura que nos permita su aislamiento como pueden ser "beads" magnéticas, filtros de celulosa, la superficie de placas de cultivo, silica porosa etc ${ }^{173-175}$.

\subsection{Caracterización de las vesículas extracelulares}

\section{-Caracterización del contenido}

En la caracterización de las vesículas extracelulares es de vital importancia determinar el cargo principal de estas vesículas. Aunque si bien es cierto que no existe unos marcadores específicos para determinar estas partículas sí que existen una serie de proteínas que se encuentran enriquecidas en ellos. Sin embargo, la proporción de estas proteínas puede cambiar en función de los diferentes tipos de 
EVs que estemos aislando. Se recomienda que se reporten la presencia de 3 o más proteínas presentes en las EVs de manera semi-cuantitativa al menos. Las proteínas descritas y caracterizadas deben ser proteínas que se esperen en EVs generalmente que pertenezcan a proteínas transmembrana, citosólicas con potencial a unirse a membrana. En la siguiente tabla se muestra una serie de proteínas recomendadas para la caracterización de vesículas. ${ }^{176}$

\begin{tabular}{|c|c|c|c|}
\hline $\begin{array}{c}\text { Proteínas } \\
\text { transmembrana o } \\
\text { proteínas de unión a } \\
\text { lípidos extracelulares }\end{array}$ & Proteínas citosólicas & Proteínas intracelulares & Proteínas extracelulares \\
\hline $\begin{array}{l}\text { Prueban la presencia de } \\
\text { membrana }\end{array}$ & $\begin{array}{c}\text { Con capacidad de unión a } \\
\text { membran a o a receptores } \\
\text { de membrana }\end{array}$ & $\begin{array}{c}\text { Asociado a } \\
\text { compartimentos diferentes } \\
\text { a la membrana plasmática } \\
\text { o endosoma }\end{array}$ & $\begin{array}{c}\text { Se unen de manera } \\
\text { específica o inespecífica a } \\
\text { membranas celulares }\end{array}$ \\
\hline $\begin{array}{c}\text { Presente o enriquecido en } \\
\text { EVs }\end{array}$ & $\begin{array}{c}\text { Presente o enriquecido en } \\
\text { EVs }\end{array}$ & $\begin{array}{c}\text { Ausente o } \\
\text { infrarepresentado en } \\
\text { aislamientos }\end{array}$ & $\begin{array}{c}\text { Asociación variable con } \\
\text { EVs }\end{array}$ \\
\hline ejemplos & Ejemplos & Ejemplo & Ejemplo \\
\hline $\begin{array}{l}\text { Tetraspaninas como CD63, } \\
\text { CD9, CD81 }\end{array}$ & TSG101, ANXA & Calnexina & Col1A, FBN \\
\hline
\end{tabular}

Tabla 2: Caracterización proteíca recomendada para los aislamientos de vesículas extracelulares, tabla adaptada del artículo. Minimal experimental requirements for definition of extracellular vesicles and their functions: A position statement from the International Society for Extracellular Vesicles. J. Extracell. vesicles 3, 26913

El aislamiento de EVs se encuentra a su vez altamente predispuesto a la contaminación con proteínas, por este motivo una caracterización que únicamente nos aporte información sobre su contenido proteico puede ser insuficiente. Por este motivo cada vez se plantea de manera más imperante la necesidad de establecer una caracterización de las partículas que hemos aislado mediante alguna prueba que nos permita conocer el tamaño de dichas partículas de las cuales enumeramos las más importantes.

-Caracterización de tamaño de las vesículas

- Microscopia electrónica

Se trata de uno de los métodos más demandados a la hora de estudiar vesículas extracelulares ya que permite observar la morfología de las vesículas tratándose pues, de una prueba directa de la presencia de estas vesículas. La resolución de los microscopios electrónicos se encuentra entre 1-3 $\mathrm{nm}^{177}$.Dentro de la microscopía electrónica se encuentra una gran variedad de protocolos para preparar la muestra de vesículas como puede ser fijación, embeber la muestra en una resina y cortarla 
en secciones de unos $100 \mathrm{~nm}$ para después teñirla ${ }^{178}$. También se pueden optar por técnicas de congelación y embebido a muy baja temperatura para observar la ultraestructura de las EVs. Cabe destacar también que para el estudio del inmunofenotipo de las EVs se pueden optar por técnicas como la detección con nanopartículas de oro en la cual las muestras de EVs se incuban con partículas de oro de unos 4-40nm que a su vez se encuentran ligadas a anticuerpos que reconocen las proteínas de membrana más abundantes en las EVs ${ }^{179}$.

- Citometría de flujo

Esta herramienta permite el análisis de las EVs en biofluidos por medio del paso de la muestra por un láser que genera una emisión de luz dispersada y fluorescencia que se mide mediante el uso de una serie de fotomultiplicadores. Si bien es cierto que la partícula no llega a visualizarse, los diagramas proporcionados por esta técnica nos permiten distinguir de manera aproximada el tamaño de las vesículas que tenemos en nuestra solución mediante técnicas de luz dispersada

La luz dispersada se propuso como uno de los métodos para determinar la presencia de las EVs en las muestras, sin embargo la intensidad que produce las EVs muchas veces se confunde con el ruido presente por el propio instrumento y, aunque se han intentado calibrar el tamaño de las vesículas usando beads de silica o polietireno, estos dan lugar a resultados contradictorios ya que la dispersión de luz es una función compleja en la que interviene el diámetro de la partícula, el índice de refracción y longitud de onda de la iluminación. Esto sumado a que los eventos detectados provienen de una señal simultanea de un conjunto de EVs hacen que el análisis de FC sea susceptible a crear resultados artefactuales ${ }^{180,181}$.

\section{- Nanoparticles Track Analysis}

Esta técnica es una herramienta que combina tanto las propiedades de la microscopia de dispersión de luz y el movimiento browniano de las partículas para obtener una distribución del tamaño de las partículas en la suspensión líquida. La mayoría de los equipos que se comercializan hoy en día se encuentran equipados con uno o más láser y un microscopio óptico conectado a una cámara digital. Las partículas son visualizadas por la luz que dispersan después de ser iluminadas por el láser y el microscopio conectado a la cámara registra el movimiento browniano de estas partículas. Mediante el uso de un software que monitoriza este movimiento es capaz de caracterizar el tamaño de las partículas en un rango entre 10-2000 nm en la solución aplicando la ecuación de Stokes-Einstein ${ }^{182,183}$. 
Algunos de estos equipos a su vez incorporan un láser que permite la detección de la luz dispersada, así como modo de fluorescencia (F-NTA). Así, el NTA permite el análisis del tamaño de las partículas mediante el movimiento browniano también es capaz de estimar una concentración en la muestra en relación con el número de partículas que son captadas en la cámara y al volumen de la celda. Es importante remarcar que el movimiento browniano que presentan las partículas depende en gran medida de las propiedades del medio en el que se encuentran. ${ }^{184}$

\subsection{Papel de las EVs en la terapia cardiaca}

Como se ha comentado anteriormente, aunque se han llevado a cabo estudios prometedores en terapia celular para el tratamiento de las enfermedades cardiacas, estos resultados no se han trasladado a los ensayos clínicos que existen actualmente. Por una parte sabemos que las células inyectadas en el músculo cardiaco apenas son responsables de los nuevos cardiomiocitos generados en estos siendo estos últimos de origen interno $^{185}$. Sin embargo, la mejora que se podía ver en estos estudios se debe al factor paracrino generado por este tipo de células, en las cuales las vesículas extracelulares juegan un papel importante.

\subsubsection{EVs derivadas de cardiomiocitos en comunicación celular.}

Una de las primeras áreas a estudiar en el papel de las EVs en la terapia cardiaca es la posibilidad de que estos EVs puedan actuar como posibles marcadores diagnósticos de una enfermedad. Debido a los diferentes perfiles existentes en el contenido de las vesículas en función de su estado tenemos que las EVs pueden jugar un rol central en la comunicación tanto con cardiomiocitos así como otros tipos celulares en diferentes condiciones de estrés como puede ser, deprivación de glucosa ${ }^{186}$, inflamación ${ }^{187}$ etc. Cardiomiocitos que se encuentran en procesos de apoptosis liberan al medio vesículas con concentraciones elevadas de ciertas moléculas que pueden servir como marcador diagnóstico. Por ejemplo, se encuentra descrito que en pacientes con infarto de miocardio las vesículas extracelulares en el plasma poseen niveles elevados de miRNAs que se activan mediante p-53 como el miRNA-192, miRNA-194, miRNA$34 \mathrm{a}^{188,189}$.

En estudios donde se lleva a cabo deprivación de glucosa en los cardiomiocitos se ha demostrado que las vesículas que secretan estos mismos se encuentran enriquecidas en transportadores funcionales de glucosa y enzimas glicolíticos. Estas EVs se 
internalizan por las células endoteliales e incrementan la internalización de glucosa en estas células así como su actividad glicolítica ${ }^{190}$.Otros estudios a su vez plantean que los cardiomiocitos que han sufrido algún tipo de daño secretan vesículas que son capaces de afectar a la supervivencia de células madre de la médula ósea en una zona infartada mediante la activación de Rab2 $7^{191}$.

\subsubsection{EVs derivadas de otros tipos celulares como terapia cardiaca}

Con el objetivo de determinar si las vesículas extracelulares son capaces de recopilar la multitud de efectos terapéuticos derivados de las propias células mesenquimales se han llevado a cabo una gran cantidad de estudios para probar esta hipótesis. Dentro de estos estudios se han evaluado diversas fuentes de células mesenquimales, además de una focalización en el contenido terapéutico de las EVs. Estudios preclínicos han demostrado que una inyección intravenosa de EVs derivadas de células pluripotentes inducidas (iPSC) 48h después de un infarto son capaces de mejorar la función del ventrículo izquierdo, así como reducir la masa ventricular y una reducción en la apoptosis de la zona infartada. Similares resultados se han obtenido con EVs derivadas de células madre embrionarias en las cuales se podría observar una menor fibrosis miocárdica, así como un área de infarto reducida, y una mejor función cardiaca ${ }^{192,193 .}$

El contenido de las vesículas, así como su posterior internalización puede activar diferentes vías en un cardiomiocito que se encuentre dañado por una señalización a nivel de proteínas, miRNAs etc.

Exosomas derivados de células mesenquimales de tejido adiposo han demostrado a través del miRNA músculo específico miR-320d que afecta a la vía de STAT3 y tienen una repercusión en la inhibición de la apoptosis en cardiomiocitos que presentan fibrilación atrial ${ }^{194}$.

Otros estudios centrados en las CPCs (cardiac progenitor cells) que se encuentran dentro del corazón adulto en principio ponían en evidencia como el trasplante de estas células en un corazón dañado podrían dar lugar a la reparación del órgano por diferenciación de estas células. Sin embargo estudios recientes demuestran que estas CPCs también son capaces de segregar EVs que, vía diversos miRNAs como pueden ser el miRNA-21 enriquecido en estas vesículas, puede afectar a la supervivencia de los cardiomiocitos mediante inhibición del PDCD $4{ }^{195}$. 


\subsubsection{Uso de EVs vs células}

Como se ha descrito anteriormente las terapias actuales con MSCs han demostrado su eficacia en multitud de estudios in vitro e in vivo siendo incluso llevados a cabo ensayos clínicos con prometedores resultados. Sin embargo, el uso de MSC como terapia celular todavía cuenta con muchos inconvenientes al tratarse de células vivas. $\mathrm{Al}$ tratarse de células con capacidad replicativa no existe la capacidad de eliminar estas células incluso una vez haya terminado la terapia ${ }^{196}$, en ciertos estudios en animales se ha observado una osificación o calcificación de ciertos tejidos debido a diferenciaciones de estas MSCs trasplantadas ${ }^{197}$, así como la inducción al crecimiento de posibles tumores presentes en el paciente ${ }^{198}$. Otra de las desventajas que plantea es que debido a su gran tamaño estas células pueden actuar de manera oclusiva en la microvasculatura más pequeña. En contraposición, las EVs minimizan este riesgo oclusivo al tratarse de vesículas de un tamaño mucho menor, la presencia de vesículas va desapareciendo con el tiempo en el paciente lo que evita totalmente los posibles efectos dañinos que pueda tener el hecho de inyectar células vivas en un paciente. Las EVs a su vez presenta una menor probabilidad de generar una reacción inmune después de su administración ${ }^{199,200}$.

\section{4.miRNAs}

\subsection{Definición de los miRNAs}

Los miRNAs son pequeñas secuencias de ARN no codificante de unas 20-25 nucleótidos que son capaces de regular la expresión génica en la célula por medio de la represión de RNA mensajero. Los miRNAs se descubren por primera vez en 1993 por los grupos de Ruvkun y Ambros en la especie Caenorhabditis elegans ${ }^{201}$. Desde entonces los miRNAs han sido detectados en todos los modelos animales mostrando además una fuerte conservación entre diferentes especies ${ }^{202}$. Los miRNAs se transcriben a partir del DNA como un miRNA primario (pri-miRNA) el cual es procesado para dar lugar a un pre miRNA y posteriormente un miRNA maduro. En la mayoría de casos los miRNAs se unen a la región 3' UTR de las secuencias codificantes de los mRNAs para suprimir su expresión sin embargo se puede unir a otras regiones como la región 5' UTR e incluso se encuentra descrito que algunos miRNAs pueden aumentar la expresión de un gen en determinadas condiciones ${ }^{203} 204$. 


\subsection{Papel de los miRNAs en la terapia cardiaca}

Se encuentra demostrado que los miRNAs son capaces de unirse de manera imperfecta a los mRNAs de manera que una unión de 7 nucleótidos en el extremo 5' es suficiente en muchas ocasiones para que el miRNA ejerza su función. Este hecho a su vez hace que un solo miRNA sea capaz de regular cientos de mRNAs siendo pues de vital importancia en el desarrollo cardiaco. Los miRNAs han sido fuertemente estudiados en este campo, experimentos con ratones modificados genéticamente para no expresar la proteína DICER, necesaria para la generación de miRNAs, han demostrado que la ausencia de miRNAs en estos ratones produce la letalidad cardiaca del embrión al día 12 de gestación ${ }^{205,206}$.

A su vez, existen una serie de miRNA de expresión únicamente cardiaca como puede ser los miRNAs miR-1 y miR-133. La sobreexpresión de miR-133 en corazones de ratón puede dar lugar a estrechamiento ventricular y decrecimiento de la población de cardiomiocitos dando lugar a $\mathrm{IC}^{207}$. Luego en circunstancias de patología cardiaca se expresan estados de miRNAs alterados. Estos miRNAs dependerán de la patología haciendo de ellos una potente herramienta de diagnóstico e incluso de tratamiento de la enfermedad. En la siguiente tabla se resumen las poblaciones de miRNAs alterados en las distintas patologías cardiacas.

\begin{tabular}{|c|c|c|}
\hline miRNA & Diana & Función regulada \\
\hline miR-1 & Calmodulina, GATA bp4 & $\begin{array}{l}\text { Regulación de proliferación } \\
\text { celular y diferenciación }\end{array}$ \\
\hline miR-15 & Chek-1 & $\begin{array}{l}\text { Influencia la supervivencia } \\
\text { celular así como el ciclo celular }\end{array}$ \\
\hline Cluster miR17-92 & BIM & Modula la cardiogénesis \\
\hline $\operatorname{miR-21}$ & MAPK & $\begin{array}{l}\text { Regula la vía de las MAPK } \\
\text { asociada a la patogénesis } \\
\text { cardiaca }\end{array}$ \\
\hline miR-24 & Dominio BH3 de BIM & Regula apoptosis \\
\hline miR-29 & $\begin{array}{l}\text { Colágeno, metaloproteinasas, } \\
\text { fibras extracelulares }\end{array}$ & $\begin{array}{l}\text { Regulación de procesos de } \\
\text { fibrosis cardiaca }\end{array}$ \\
\hline miR-34 & Sirt1, Porfut1, VEGF & $\begin{array}{l}\text { Regulación de apoptosis y } \\
\text { angiogénesis }\end{array}$ \\
\hline miR-133a & Rhoa, Cdc42 & $\begin{array}{l}\text { Regulación de la proliferación } \\
\text { celular y diferenciación }\end{array}$ \\
\hline
\end{tabular}




\begin{tabular}{|l|l|l|}
\hline miR-199b & Dysk1a & $\begin{array}{l}\text { Señalización } \\
\text { Calmodulina/NFAT }\end{array}$ \\
\hline miR-214 & $\begin{array}{l}\text { Ciclofilina, } \\
\text { dependiendiente } \\
\text { Ca/calmodulina }\end{array}$ & $\begin{array}{l}\text { Regulación del metabolismo } \\
\text { energético y la contracción }\end{array}$ \\
\hline miR-378 & MAPK; TGFß1, IGF1R & Remodelado cardiaco y fibrosis \\
\hline miR-499 & Calcineurina,Egr1, Egr2 & $\begin{array}{l}\text { Efecto protector ante el daño } \\
\text { por isquemia }\end{array}$ \\
\hline miR-652 & Jagged1 & Angiogénesis y apoptosis \\
\hline
\end{tabular}

Tabla 3: Resumen de miRNAs relacionados con la terapia cardiaca. Tabla adaptada del artículo miRNA therapeutics: A new class of drugs with potential therapeutic applications in the heart. Future Med. Chem. 7, 1771-1792 (2015).

Teniendo esto en cuenta se han desarrollado diversas estrategias para controlar los niveles de miRNAs en condiciones patológicas. Una de ellas se basa en disminuir los niveles de miRNAs sobreexpresados, para ello se pueden hacer uso de oligo RNAs antisentido que se unen a los miRNAs maduros creando una doble cadena que posteriormente es degradada. También existen métodos como las llamadas esponjas de miRNAs las cuales se basan en introducir una cadena larga de RNA en cuya secuencia se encuentra altamente repetida la secuencia antisentido del miRNA a inhibir. Esto hace que esta cadena secuestre una gran cantidad de copias de este miRNA maduro impidiendo que ejerza su función.

En aquellos casos en los que los niveles de miRNA se encuentre infra-expresados, se han desarrollado herramientas que permiten aumentar los niveles de miRNAs. Un ejemplo es el uso de secuencias "mimics" cadenas dobles de pre-miRNA que posteriormente es procesado en la célula para dar lugar a un miRNA maduro.

Sin embargo, uno de los grandes desafíos de esta tecnología es inducir un tropismo preferencial en la secuencia de miRNA. Esto se puede hacer mediante el uso de nanopartículas liposomales, pequeñas estructuras que son capaces de incorporar los mimics en su fase acuosa del poro del liposoma y pueden hacer que lleguen de manera selectiva a ciertos órganos o tipos celulares mediante la conjugación de estas partículas a determinados anticuerpos. A su vez también se ha descrito el uso de vectores virales con un tropismo órgano-específico para sobreexpresar el miRNA de manera preferencial en dichos órganos. Especialmente el uso de adenovirus en este campo es de vital importancia ya que dependiendo del serotipo de este adenovirus se pueden 
seleccionar órganos diana. Sin embargo, esto plantea diferentes problemas en la terapia humana debido al uso de virus en humanos así como la respuesta inmune que puedan desarrollar a este tipo de virus podría afectar en la terapia ${ }^{208}$.

Cabe destacar, la importancia de los miRNAs como herramienta en la diagnosis y la prognosis de las enfermedades cardiovasculares. Los miRNAs circulantes presentes en un paciente pueden indicar la enfermedad de un paciente o incluso el riesgo a sufrir cierta enfermedad por ellos. Diversos cambios en alrededor de 30 miRNAs circulantes han demostrado encontrarse asociados con la patología cardiaca, así como sus patologías de comorbilidad. Por ejemplo, se encuentra demostrado en una cohorte de 2204 pacientes que niveles alterados de miRNAs miR-1254 y miR-1306 se asociaban con un riesgo incrementado de hospitalización y muerte de los pacientes. Otros miRNAs asociados con riesgo cardiaco y muerte son miR-208b y miR499. ${ }^{209}$ 


\section{HIPOTESIS Y OBJETIVOS}




\section{Hipótesis}

A la luz de los hechos explicados en el apartado de introducción del trabajo. Se postulan las siguientes hipótesis de trabajo:

- Existe una comunicación vesicular por parte de las células que componen el sistema cardiaco que permite la comunicación activa entre las diferentes poblaciones celulares.

- Esta comunicación cardiaca mediada por vesículas extracelulares es variable en función del estado de la célula progenitora, así como la célula que capta la vesícula.

- Además de la comunicación vesicular existe un patrón de miRNAs característico en pacientes sanos que se ve alterado cuando existe una patología cardiaca o una predisposición a sufrirla.

- La predisposición a sufrir episodios de cardiotoxicidad derivada de antraciclinas se traduce en un patrón de miRNAs que se encuentra alterado en el suero de los pacientes. De esta manera un estudio de los niveles de unos miRNAs concretos presentes en los sueros de pacientes previo al tratamiento con antraciclinas, podría detectar esta predisposición.

- Una correlación de la cardiotoxicidad con los niveles de miRNAs nos permitiría crear un algoritmo de predicción de cardiotoxicidad en función de la cuantificación de los miRNAs.

- Los miRNAs diferencialmente expresados en pacientes con cardiotoxicidad frente a controles pueden tener un papel importante en la patología cardiaca pudiendo actuar como agentes terapéuticos tanto en la cardiotoxicidad derivada de antraciclinas como otras patologías cardiacas como puede ser la cardiopatía isquémica.

- Las EVs derivadas de MSCs pueden recapitular los efectos terapéuticos de sus células progenitoras ejerciendo un papel protector frente a la cardiotoxicidad derivada de antraciclinas y la cardiopatía isquémica. 


\section{$\underline{\text { Objetivos }}$}

Para intentar corroborar las hipótesis planteadas en el apartado anterior se plantean los siguientes objetivos:

- Aislar y caracterizar vesículas de células cardiacas variando las condiciones de cultivo para analizar el efecto en el contenido de las vesículas.

- Estudiar el efecto de la adicción de las vesículas extracelulares de los cardiomiocitos cultivados en diferentes condiciones en las diferentes poblaciones cardiacas como células endoteliales o fibroblastos.

- Recopilar una cohorte de pacientes sanos y con cáncer de mama para extraer muestras de suero pre-tratamiento con antraciclinas con los que se determinará los miRNAs diferencialmente expresados entre ambas.

- Cuantificar los miRNAs expresados en estos pacientes por secuenciación y seleccionar los de una mayor significancia. Seguidamente comprobar por qPCR los resultados obtenidos en la secuenciación.

- Una vez cuantificados los miRNAs desarrollar un algoritmo de predicción que nos permita predecir la capacidad a sufrir cardiotoxicidad mediante la medición de los mismos.

- Estudiar el papel de las EVs derivadas de MSCs en los procesos de supervivencia de cardiomiocitos frente a la cardiotoxicidad y la patología isquémica así como su efecto en otras poblaciones cardiacas importantes estudiando procesos como fibrosis cardiaca o angiogénesis.

- Comprobar el efecto de estos miRNAs seleccionados en otras patologías cardiacas en la cardiotoxicidad y la patología isquémica 
MATERIALES Y MÉTODOS 


\section{$\underline{\text { 1.Inclusión de pacientes }}$}

Los pacientes en este trabajo han sido incluidos en el contexto de la elaboración de un proyecto prospectivo observacional llevado a cabo por las entidades HUiPLaFe y el Instituto Valenciano de Oncología IVO. Las pacientes incluidas en el estudio HECATOS son pacientes diagnosticadas de cáncer de mama a las que se les ha tratado mediante cirugía. Estas pacientes fueron incluidas en el estudio antes de recibir la quimioterapia. Todas las pacientes tenían una edad de más de 18 años y han firmado un consentimiento informado. En esta cohorte de pacientes se incluyen un total de 140 pacientes de los cuales podemos encontrar diferentes tipos de cáncer de mama (luminal A, luminal B, triple negativo y HER 2+) así como diferentes estrategias terapéuticas que se dividen en:

- TAC (Taxotere, Adriamicina y Ciclofosfamida cuyas dosis administradas son de Docetaxel $75 \mathrm{mg} / \mathrm{m}^{2}$, doxorrubicina (adriamicina ${ }^{\circledR}$ ) $50 \quad \mathrm{mg} / \mathrm{m}^{2}$ y ciclofosfamida en $500 \mathrm{mg} / \mathrm{m}^{2}$ en 6 ciclos espaciados durante 21 días.

- AC (Adriamicina y ciclofosfamida) estos ciclos consisten en doxorrubicina $60 \mathrm{mg} / \mathrm{m}^{2}$ y ciclofosfamida $600 \mathrm{mg} / \mathrm{m}^{2}$ en 4 ciclos de 21 días. Al terminar estos ciclos se administra Paclitaxel $\left(80 \mathrm{mg} / \mathrm{m}^{2}\right)$ o Docetaxel $\left(100 \mathrm{mg} / \mathrm{m}^{2}\right)$ semanalmente por 12 semanas o en ciclos cada 21 días durante 4 ciclos. Los pacientes HER2+ fueron tratados con AC seguidos con Trastuzumab (Herceptina ${ }^{\circledR}$ ) 600mg en 12 ciclos de 21 días.

Además de estos pacientes se reclutó para el estudio una segunda cohorte de 32 pacientes con cáncer de mama en otro hospital usando el mismo protocolo de tratamiento. En ambas cohortes lo que se busca evaluar es la presencia/ausencia de fenómenos de cardiotoxicidad, por lo que se clasificarán en función de la definición de cardiotoxicidad más reciente según las guías ya sea una reducción del 5\% en la FEVI dando lugar a una FEVI final menor al 53\% en pacientes con síntomas de IC o una reducción del 10\% para una FEVI final menor al 53\% sin presencia de síntomas. En ambas cohortes los pacientes han sido clasificados como controles si no han sufrido ningún proceso de cardiotoxicidad o casos si han tiendo una disminución de la FEVI durante el primer año de tratamiento con antraciclinas. 


\subsection{Parámetros clínicos}

Los datos clínicos de las pacientes fueron recogidos antes de los ciclos de quimioterapia efectuados. Estos datos incluyen un historial médico, así como ciertos datos demográficos, también se incluyen riego de sufrir alguna enfermedad cardiovascular, usos de medicación, regímenes de medicación antineoplásica, síntomas o signos de enfermedad cardiovascular, resultados de exámenes físicos, así como resultados de rutina de laboratorio o ecocardiografías.

\subsection{Ecocardiografía}

La ecocardiografía a las pacientes de cáncer de mama se llevó a cabo antes y después del tratamiento con antraciclinas además de 12 y 24 meses después del tratamiento. La ecocardiografía fue llevada a cabo para realizar medidas de la estructura del ventrículo izquierdo y la función global cardiaca, para ello se usaron las medidas del flujo sanguíneo en dos dimensiones y el Doppler Blood Flow. Todas las medidas se llevaron a cabo teniendo en cuenta las principales guías de la American Society of Ecocardiography usando un iE33 (Philips Medical Systems, Andover,MA) con transductores transtorácicos $\mathrm{S} 5-1$ y X5-1 (frecuencia $=1-5 \mathrm{~Hz}$ ). Las medidas del grosor de la pared se calculó usando la vista paraesternal de eje largo mientras que los diámetros sistólico y diastólico del ventrículo izquierdo así como el volumen fueron calculados mediante la ecuación de Teicholz (LVV=(7/2.4+LVD)*LVD). Las áreas en diástole y sístole se midieron desde la cuarta cámara apical y la segunda cámara. La fracción de eyección se calcula usando estas imágenes mediante el método de plano de Simpson modificado. Todas las medidas han sido realizadas por un único especialista ajeno al resto de parámetros clínicos del paciente.

La deformación cardiaca sistólica o "strain" se mide usando el método GLS (Speckletracking) en dirección longitudinal. Para determinar este valor se toman tres puntos de referencia manualmente posicionados: uno en cada lado de la válvula mitral y el tercero en el borde apical endocárdico. Para ello se utiliza el sistema Automated Cardiac Motion Quantification (aCMQ, QLAB 9; Philips Medical Systems)

\subsection{Extracción de muestras de pacientes}

Las muestras de sangre de la principal cohorte se toman antes de empezar los ciclos de quimioterapia, así como a los diferentes puntos de esta. También se tomaron muestras de las pacientes meses después del final del tratamiento con las antraciclinas 
en función de la disponibilidad de los pacientes. La sangre se extrae en tubos no heparinizados donde se dejan a $4^{\circ} \mathrm{C}$ durante 2 horas. Seguidamente se centrifugan a 10.000Gs durante 15 minutos tras lo cual el suero de alicuota y las muestran se guardan en el biobanco del hospital universitario la Fe (HUiPLaFe Biobank) donde son procesadas siguiendo los estándares de procedimientos apropiados según los comités éticos y científicos. Las muestras de sangre de la segunda cohorte fueron extraídas en tubos heparinizados de los cuales se separa el plasma que es almacenado en el biobanco HCSC.

\section{Métodos Informáticos}

\subsection{Estadística y figuras}

Para la realización de los análisis estadísticos así como de las figuras de los resultados in vitro e in vivo se ha utilizado el software Graphpad Vs 8.0 utilizando el test estadístico correspondiente en función de la prueba.

\subsection{Secuenciamiento miRNA}

Para el secuenciamiento del miRNA, este se aísla a partir del suero de los pacientes usando el kit miRNeasy Mini Kit (Qiagen, Westburg BV, Leusden, The Netherlands). Los miRNAs se seleccionan y ligan mediante el uso de TruSeq Small RNA library Preparation Kit (Illumina, San Diego CA). Las muestras se secuencian en una plataforma Illumina HiSeq 2000 como una media de 4.6 millones de lecturas. Los datos sin procesar se filtraron para retirar del análisis secuencias adaptadoras y se mapearon contra secuencias de miRNAs conocidas extraídas de la plataforma mirBase usando Patman. La secuenciación se llevó a cabo en el servicio de toxicología de la Universidad de Maastricht, Países Bajos.

Para el tratamiento de los datos obtenidos del análisis de miRNAseq y, puesto que este análisis es altamente dependiente del método que se utilice, se decidió utilizar tres métodos de análisis diferentes llamados Robinson and Smyth exact negative binomial, Random Forest y Elastic Net. El test de Robinson and Smyth exact negative binomial se trata de un método cuyo punto fuerte radica en encontrar diferencias significativas cuando el número de replicas es bajo. ${ }^{210}$ El test Random Forest se trata de una herramienta basada ensamblamiento ramificado. Este método es capaz de hacer correlaciones especialmente buenas con datos genómicos de alta dimensionalidad ${ }^{211}$. Mientras que el test de Elastic Net se basa en la creación de un modelo de regresión 
lineal que se corrige cuando existen demasiadas variables en el modelo, mejorando la capacidad que un modelo simplemente lineal puede ofrecer cuando el número de variables es mayor que el número de muestras ${ }^{212}$.

Estos tres métodos se utilizaron para encontrar miRNA discriminativos entre el grupo de los casos (pacientes que han desarrollado la cardiotoxicidad) vs los controles (pacientes con cáncer de mama que no desarrollan la cardiotoxicidad). Estos análisis se llevaron a cabo en los diferentes puntos de tratamiento de los pacientes en los cuales distinguiremos tres, Pre tratamiento con antraciclinas, Post- Tratamiento con antraciclinas y Rev 12 meses después de la finalización del tratamiento. Los resultados de este análisis generaron una lista de miRNAs que se encuentran desregulados en los casos con respecto a los controles. Para representar la expresión diferencial de los miRNAs en las muestras de suero se representaron los datos en un diagrama de Volcano Plots en los que el eje de significancia se representa en valores de p-valor y la diferencia como $\log _{2}$ del fold change. Para estimar la dispersión y los fold-changes se utilizó el método Dseq2 de R package con el objetivo final de mejorar la estabilidad y la interpretación de las estimaciones. Todos los análisis estadísticos fueron llevados a cabo usando R (versin 3.6.1) y R-packages Random forest (versión 4.6-12) glmnet (verison 2.0-16), NBPSeq (versión 0.3.0), lme4 (versión 1.1-19) y rms (versión 5.1-2)

\subsection{Generación de algoritmo predictivo}

Una vez se han llevado a cabo los análisis mediante los tres métodos previamente descritos, se generan una lista de miRNAs que se consideran diferencialmente expresados entre casos y controles que son capaces de predecir el riesgo de sufrir disfunción cardiaca después de completarse la quimioterapia. Para generar un algoritmo predictivo se creó un modelo logístico en el que se consideran los diferentes valores de los miRNAs como potenciales predictores y los individuos como factores aleatorios. La selección de variables se ajustó usando el criterio de información de Akaike seleccionando el modelo con la menor AIC. El modelo final se eligió estimando el área bajo de la curva ROC (AUC) junto con una versión corregida con la técnica "bootstrapped". P valores por debajo de 0.05 son considerados estadísticamente significativos.

\subsection{Estudio del Interactoma}

Los bloques funcionales de los procesos biológicos (GO) fueron usados en el análisis con Cytoscape software v3.7.2 (www.cytoscape.org/). Las imágenes del interactoma 
se construyen usando los datos RNAseq pre y post tratamiento tanto para pacientes controles como los casos. Se fija la significancia estadística en 0.05 para los cuales se considera que los procesos biológicos con una significancia menor a este valor se consideran diferencialmente expresados. Las funciones biológicas o GOs fueron organizados en un gráfico de estructura acíclica directa, en los gráficos generados solo se muestran las funciones significativas y no redundantes. Los bloques de funciones diferencialmente expresadas en las dos condiciones (Pre antraciclinas y Post antraciclinas) se definen por el logaritmo del ratio Lor donde un Lor positivo indica niveles superiores de regulación del miRNA en el proceso biológico.

\subsection{Análisis proteómicos}

Para esta técnica las muestras se encuentran en tampón RIPA, las cuales son

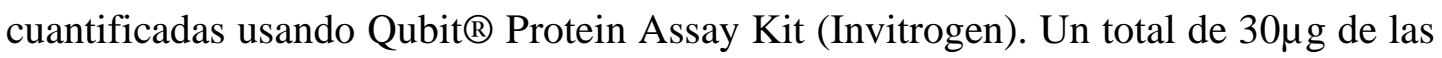
proteínas se corren en un gel de $12.5 \%$ de acrilamida 1D SDS-PAGE. Seguidamente las proteínas son digeridas con tripsina. La digestión se detiene usando una solución del $1 \%$ de ácido trifluoroacético de los cuales $5 \mu \mathrm{L}$ se usarán para una cromatografía líquida en tandem con una espectrometría de masas (LC-MS/MS). Los datos se analizaron usando los parámetros de serie del ProteinPilot (ProteinPilot v4.5. search engine, ABSciex) Las proteínas se ordenaron siguiendo una puntuación llamada Unused Protein Score, la cual se trata de una medida de comparación entre las proteínas obtenidas vs las proteínas de la base de datos. Se hace un análisis de enriquecimiento funcional para detectar las asociaciones entre los diferentes GOs y los grupos experimentales. Esta caracterización funcional nos permite determinar el conjunto de procesos biológicos que se encuentran sobrerrepresentados en nuestro subgrupo de proteínas. Los procesos biológicos diferencialmente expresados se recogen en un TreeMap usando la función web REVIGO que permite la comparación de resultados entre grupos y es de especial utilidad para revelar patrones funcionales.

\section{Métodos bioquímicos}

\subsection{Extracción de miRNAs y qPCR}

La extracción de miRNAs se llevó a cabo usando el kit miRNeasy kit (Qiagen Inc) siguiendo las indicaciones del fabricante salvo algunas variaciones. En primer lugar, las muestras de suero o de plasma se descongelan en hielo y se centrifugan durante 10 
min a $10.000 \mathrm{G} \mathrm{a} 4^{\circ} \mathrm{C}$ para retirar cualquier posible debrí o contaminante macroscópico que pueda existir. Seguidamente se recogen $200 \mu 1$ del sobrenadante y se añaden sobre QIAzol "lysis reagent" al que previamente hemos añadido RNA del fago MS2 (ThermoFisher Scientific) y un número conocido de copias de cel-miR-39-3p (MIMAT0020306, SigmaAldrich) que servirá posteriormente como control interno del proceso. Esta mezcla se agita y se deja incubar a temperatura ambiente durante $5 \mathrm{~min}$. Seguidamente los tubos se centrifugan a 15 min $12.000 \mathrm{Gs}$ a $4^{\circ} \mathrm{C}$. Esta centrifugación genera dos fases bien definidas en el tubo, una orgánica (fase inferior de color rosado) y una fase acuosa (fase superior transparente). Se recogen $280 \mu \mathrm{L}$ de la fase acuosa y se mezclan con $420 \mu 1$ de etanol $100 \%$. Esta mezcla se introduce en las columnas provistas por el kit RNeasy minElute spin columm donde la muestra se lava secuencialmente con los Buffer RWT y dos veces con el Buffer RPE. Seguidamente los miRNAs se eluyen de la columna utilizando $35 \mu \mathrm{L}$ de agua RNase-free. Esta elución puede usarse justo después sin embargo si no es el caso se congela a una temperatura de $-80^{\circ} \mathrm{C}$.

\subsection{Transcripción inversa}

Para ello se utiliza el kit de transcripción inversa miRCURY LNA Universal RT microRNA PCR Kit (Qiagen Inc) en el cual $2 \mu 1$ del miRNA eluido se mezclan con $2 \mu \mathrm{L}$ de "Reaction Buffer 5x", $1 \mu \mathrm{L}$ de "Enzyme mix" y agua libre de nucleasas alcanzando así un volumen final de $10 \mu \mathrm{L}$. La mezcla se incubó durante $60 \mathrm{~min}$ a $42^{\circ} \mathrm{C}$ seguido de una inactivación de la transcriptasa mediante una incubación de 5 min a $95^{\circ} \mathrm{C}$. Una vez llevada a cabo esta reacción el producto se congela a $-20^{\circ} \mathrm{C}$

\subsection{Cuantificación de miRNA por qPCR}

Para este propósito se utilizó el kit miRCURY LNA Universal RT microRNA PCR Kit(Qiagen Inc) siguiendo las instrucciones del fabricante en las que el cDNA obtenido del paso anterior. Se diluye en una proporción 1/80 en agua libre de nucleasas. Seguidamente $4 \mu 1$ de la dilución se mezclan con $1 \mu \mathrm{L}$ de PCR primer y $5 \mu \mathrm{L}$ de PCR Master Mix. Los ciclos de temperatura utilizados son de $95^{\circ} \mathrm{C}$ durante 10 min seguido de 40 ciclos de $95^{\circ} \mathrm{C}$ durante 15 segundos y $60^{\circ} \mathrm{C}$ durante 1 min. Estas qPCR fue llevada a cabo usando el Viia TM 7 Real-Time PCR System (Applied Biosystems, Carlsbad, USA). La monitorización de la reacción se llevó a cabo usando el Sofwtare QuantStudo Real-Time PCR Software and DataAssiste v3.01 (Applied Biosystem). Como miRNA control se ha utilizado el miRNA-16-5p y como control interno el cel$\operatorname{miR}-39-3 p$ 
La lista de todos los primer utilizados para esta tesis se detallan en la siguiente tabla

\begin{tabular}{|c|c|c|}
\hline Primer & Referencia & MIMAT \\
\hline YP00204660 & hsa-miR-150-5p & MIMAT0000451 \\
\hline YP00205702 & hsa-miR-16-5p & MIMAT0000069 \\
\hline YP00204606 & hsa-miR-22-3p & MIMAT0000092 \\
\hline YP00204598 & hsa-miR-215-5p & MIMAT0000272 \\
\hline YP00204384 & hsa-miR-92b-3p & MIMAT0003218 \\
\hline YP00204258 & hsa-miR-92a-3p & MIMAT0000092 \\
\hline YP00205867 & hsa-miR-148a-3p & MIMAT0000243 \\
\hline YP00204765 & hsa-miR-30b-5p & MIMAT0000420 \\
\hline YP00204107 & hsa-miR-486-3p & MIMAT0004762 \\
\hline YP00204099 & hsa-miR-192-5p & MIMAT0000222 \\
\hline YP02106069 & hsa-miR-4732-3p & MIMAT0019856 \\
\hline YP00203952 & cel-miR-39-3p & MIMAT0020306 \\
\hline
\end{tabular}

\subsection{Extracción de proteínas}

Para llevar a cabo la extracción de proteínas partiendo de cultivos celulares se siguió el siguiente procedimiento. En primer lugar, se retira el medio de las células y se lava este cultivo con PBS para retirar el posible medio que quede en el pocillo. A continuación, se añade una cantidad variable de tampón RIPA 1X (Sigma-Aldrich) previamente suplementando con inhibidor de proteasas cOmplete Mini (Roche) e inhibidor de fosfatasas PhosStop EASYpack (Sigma Aldrich). Se incuban las células con esta solución durante 10 minutos a una temperatura de $4^{\circ} \mathrm{C}$ tras los cuales se centrifuga la muestra a $15.000 \mathrm{Gs}$ durante $15 \mathrm{~min}$ a $4^{\circ} \mathrm{C}$ para retirar todo el debrí celular y obtener así una muestra de proteínas libre de contaminantes celulares. El sobrenadante de esta centrifugación es transferido a un nuevo tubo. La muestra a partir de este momento siempre permanecerá en frio $\left(4^{\circ} \mathrm{C}\right)$ a menos que no se prevea su uso reciente. 


\subsection{Cuantificación de proteínas}

Para este propósito en los diferentes tipos de muestras obtenidos a lo largo de este trabajo se utilizó el kit comercial Pierce BCA Protein Assay (ThermoFisher Scientific), basado en la rección proteínica en la que las proteínas reducen el $\mathrm{Cu}^{2+} \mathrm{a} \mathrm{Cu}^{+}$de manera concentración-dependiente. Este $\mathrm{Cu}^{+}$reacciona con otro componente del kit (ácido bicincónico) formando un compuesto de coloración purpura con un pico de absorbancia máxima en $562 \mathrm{~nm}$. Esta absorbancia es directamente proporcional a la concentración proteica, para cuantificar las proteínas se realiza una curva patrón para cada cuantificación proteica mediante el estándar interno de concentración conocida

Una vez se ha dispuesto la curva patrón se toman $10 \mu 1$ de cada uno de los puntos y se mezclan con $190 \mu \mathrm{L}$ de una mezcla de ambos componentes del kit en proporción 50:1 de los componentes A y B (carbonato de sodio+ ácido bicinconínico y tartrato de sodio en solución de $\mathrm{NaOH}$ y sulfato de cobre respectivamente). Esta mezcla se mantiene en oscuridad a $37^{\circ} \mathrm{C}$ durante 20-30 minutos después de los cuales se mide la absorbancia a 570nm mediante el uso de Synergy HTX Multi-Mode Reader (Biotek)

Una vez se han obtenido las mediciones de absorbancia se crea un modelo de regresión lineal con los datos absorbancia de la curva patrón vs la concentración de esta. Este modelo regresivo nos permitirá conocer la concentración de nuestra muestra al ser ingresados los datos de absorbancia.

\subsection{Western Blot}

Mediante esta técnica se separan y detectan las diferentes proteínas de una muestra en función de su masa molecular. En primer lugar, generamos el gel por el cual correrán las muestras. Este gel se encuentra dividido en dos fases, en la primera fase "Stacking" las proteínas cargadas en el pocillo se concentran en un punto. Seguidamente pasan a la siguiente fase "Running" donde se llevará a cabo su separación. Los componentes utilizados para la generación de estos geles se enumeran a continuación: 


\begin{tabular}{|c|c|}
\hline Componentes & Running \\
\hline Agua Mq & $3.96 \mathrm{ml}$ \\
\hline $\begin{array}{c}\text { Tris 1,5 M pH } \\
\mathbf{8 . 8}\end{array}$ & $2.5 \mathrm{ml}$ \\
\hline $\begin{array}{c}\text { Acrilamida } \\
\mathbf{2 9 : 1 ~ 3 0 \%}\end{array}$ & $3.34 \mathrm{ml}^{* *}$ \\
\hline SDS & $100 \mu \mathrm{l}$ \\
\hline APS & $100 \mu \mathrm{l}$ \\
\hline TEMED & $4 \mu \mathrm{l}$ \\
\hline
\end{tabular}

\begin{tabular}{|c|c|}
\hline Componentes & Stacking \\
\hline Agua Mq & $3.15 \mathrm{~mL}$ \\
\hline Tris 1 M pH & $750 \mu \mathrm{L}$ \\
\hline $\mathbf{6 . 8}$ & \\
\hline Acrilamida & $1 \mathrm{~mL}$ \\
\hline $\mathbf{2 9 : 1 ~ 3 0 \%}$ & \\
\hline SDS & $50 \mu \mathrm{L}$ \\
\hline APS & $50 \mu \mathrm{L}$ \\
\hline TEMED & $5 \mu \mathrm{L}$ \\
\hline
\end{tabular}

** Estas concentraciones se encuentran establecidas para generar un gel del $10 \%$ de Acrilamida, sin embargo, la concentración de acrilamida es dependiente del objetivo final de separación del gel. Si en determinado momento se desea una mejor separación de proteínas más pequeñas se procederá a aumentar el porcentaje de acrilamida corrigiendo a su vez el volumen da agua para tener un volumen final de $10 \mathrm{~mL}$.

Una vez cuantificadas las proteínas estas se diluyen hasta que todas las condiciones poseen la misma cantidad de proteína. Una vez igualadas las cantidades de proteínas en todas las condiciones estas se completan con agua hasta $37,5 \mu \mathrm{L}$ y seguidamente se suplementan con $12.5 \mu \mathrm{L}$ Laemmli Sample Buffer 4x (Biorad) previamente suplementado con $\beta$-mercaptoetanol (SigmaAldrich) con el objetivo de romper los puentes disulfuro de las estructuras proteicas cargadas en el gel. Este componente, junto con el SDS presente en el gel que dota de carga negativa a todas las muestras hace que la migración de estas sea únicamente dependiente de su masa molecular y no de su carga o sus superestructuras. Estos $50 \mu \mathrm{L}$ de muestra se cargan en los pocillos del gel junto con un marcador de tamaño molecular que nos permitirá orientar el gel para saber el peso molecular que corresponde a cada posición de este. El marcador de peso molecular utilizado fue Precision Plus Protein ${ }^{\mathrm{TM}}$ Dual Color Standards (Biorad). Los geles se colocan en una cubeta de electroforesis que se rellena con un tampón electroforético (25mM Tris, $190 \mathrm{mM}$ Glicina y $0.1 \%$ de SDS) tras lo cual se cargan las muestras en el gel. Una vez cargadas las muestras junto con el marcador se conecta la cubeta a un generador de corriente (Power Pac Universal TM Power Supply) el cual se fija a un amperaje constante de $50 \mathrm{~mA}$.

Una vez separadas las proteínas en el gel desconectamos la fuente de alimentación de la corriente y preparamos los pasos para la transferencia de las proteínas una membrana. Para ello usamos las membranas PVDF Transfer Membrane $(0.45 \mu \mathrm{m}$ ThermoFisher Scientific) previa activación. Para activar la membrana en primer lugar 
la cortamos a las medidas correspondientes al gel que vayamos a transferir, seguidamente incubamos la membrana en metanol 100\% durante 15 segundos. Después, la membrana pasa a una cubeta con agua MQ durante estará equilibrándose durante unos 2 minutos, tras lo cual se lleva la membrana a incubar en el buffer de transferencia durante 15 minutos (0.25M Trizma Base, 2M Glicina y 20\% Metanol). Se genera un "sándwich" en el cual ponemos la membrana ya activada junto con el gel cubierta a su vez por ambos lados con papel y finalmente esponja de transferencia. Esta combinación se introduce en una cubeta de transferencia que se conecta al generador de corriente. Para la transferencia se fija un amperaje constante de $250 \mathrm{~mA}$ durante un tiempo variable en función del tamaño de la proteína a transferir.

Una vez la transferencia terminar se desconecta la cubeta de la corriente se extrae la membrana y se bloquea. Para el bloqueo se utilizó una solución de leche en polvo desnatada al $5 \%$ en una disolución de TBS $(50 \mathrm{mM}$ Tris-Cloruro, $150 \mathrm{mM} \mathrm{NaCl} \mathrm{pH}$ 7.6). La membrana se mantiene en esta disolución durante 1.5 horas en agitación suave a temperatura ambiente. Después de esto la membrana se incuba con los anticuerpos primarios a diferentes concentraciones en solución de bloqueo o en 5\% BSA si el anticuerpo recomienda este bloqueo. Los anticuerpos que se han utilizado para este trabajo se enumeran en la siguiente tabla.

\begin{tabular}{|c|c|c|c|}
\hline Anticuerpo & Concentración & Especie & Casa comercial \\
\hline Alix & $1 / 200$ & Mousse & Santa Cruz \\
\hline TSG101 & $1 / 500$ & Mousse & Santa Cruz \\
\hline CD63 & $1 / 500$ & Rabbit & BD \\
\hline CD81 & $1 / 500$ & Mousse & Santa Cruz \\
\hline CD9 & $1 / 500$ & Rabbit & Santa Cruz \\
\hline Cleavaged Cas 3 & $1 / 1000$ & Rabbit & Cell Signalling \\
\hline Conexina 43 & $1 / 1000$ & Rabbit & Cell Signalling \\
\hline a TUB & $1 / 2000$ & Mousse & Sigma Aldrich \\
\hline Col1A & $1 / 1000$ & Rabbit & Cell Signalling \\
\hline HSP70 & $1 / 1000$ & Rabbit & Cell Signalling \\
\hline GRP78 & $1 / 1000$ & Mousse & Santa Cruz \\
\hline a-SMA & $1 / 1000$ & Mousse & Sigma Aldrich \\
\hline Anti- Mousse HRP & $1 / 5000$ & Goat & Sigma Aldrich \\
\hline Anti-Rabbit HRP & $1 / 2000$ & Goat & DAKO \\
\hline
\end{tabular}


Una vez se ha llevado a cabo la incubación de las membranas con los anticuerpos primarios estas se lavan en TBS 3 veces durante 10 minutos con una agitación suave a temperatura ambiente. Seguidamente las membranas se incuban con el anticuerpo secundario disuelto en bloqueo en función del animal de producción del anticuerpo primario. Esta incubación se lleva a cabo durante 2 horas tras las cuales se vuelve a lavar la membrana 4 veces con TBS.

Una vez tenemos el anticuerpo primario junto con el secundario procedemos al rebelada de las proteínas para ello se utiliza el kit de revelado Amersham ${ }^{\mathrm{TM}}$ ECL $^{\mathrm{TM}}$ Prime Western Blotting Detection Reagent o el kit Thermo Scientific SuperSignal West Femto Maximum Sensitivity Substrate para aquellas proteínas de menor expresión. Las imágenes fueron tomadas en el aparato Amershan (General Electrics)

\subsection{Inmunofluorescencia}

Para este protocolo las células se siembran el día previo en cristales a una concentración de 20.000cel/ cristal (p24). Una vez terminados los tratamientos sobre estas células se fijan con $1 \mathrm{~mL}$ de paraformaldehido (PFA) al $4 \%$ durante 10 minutos a temperatura ambiente. Seguidamente se lavan 3 veces con PBS y se permeabilizan utilizando Triton X-100 0.1\% en PBS durante 20 minutos. Después de este proceso se bloquean las células con FBS al $10 \%$ en PBS durante 30 minutos a temperatura ambiente. Seguidamente las células se incuban con el anticuerpo diluido en solución de bloqueo en cámara húmeda durante toda la noche. Después de este proceso se lavan 3 veces los cristales con PBS y se incuban con el anticuerpo secundario (Alexa Fluor 488, Invitrogen) disuelto en bloqueo durante una hora en oscuridad. Después de esto los cristales se tiñen con DAPI durante 10 minutos, se lavan y se montan usando un FluorSave. Las imágenes fueron tomadas usando un microscopio de fluorescencia

\section{$\underline{\text { 4.Modelos celulares }}$}

\subsection{Medios de cultivo utilizados}

Los cultivos celulares utilizados durante esta tesis se enumeran en la siguiente tabla, todas las células utilizadas han sido manipuladas en una campana de flujo laminar e incubadas a $37^{\circ} \mathrm{C}$ con un porcentaje $5 \% \mathrm{CO} 2$ 


\begin{tabular}{|c|c|c|}
\hline Línea celular & Medio de cultivo & Marca \\
\hline \multirow[t]{3}{*}{ MSCs } & $\begin{array}{l}\text { DMEM low Glucose } \\
1 \mathrm{mg} / \mathrm{mL}\end{array}$ & Gibco-Invitrogen \\
\hline & FBS $10 \%$ & Corning \\
\hline & 10ug/mL Ciprofloxacino & Sigma Aldrich \\
\hline \multirow[t]{3}{*}{ HEK293T } & $\begin{array}{l}\text { DMEM High Glucose } \\
4,5 \mathrm{mg} / \mathrm{mL}\end{array}$ & Gibco-Invitrogen \\
\hline & FBS $10 \%$ & Corning \\
\hline & $10 \mu \mathrm{g} / \mathrm{mL}$ Ciprofloxacino & Sigma-Aldrich \\
\hline \multirow{3}{*}{ AC10 } & DMEM/F12 & Gibco-Invitrogen \\
\hline & FBS $10 \%$ & Corning \\
\hline & Ciprofloxacino $10 \mu \mathrm{g} / \mathrm{mL}$ & Sigma-Aldrich \\
\hline \multirow[t]{2}{*}{ HUVEC } & EBMTM-2 Basal Medium & Lonza $(C C-3156)$ \\
\hline & Medium-2 BulletKitTM & Lonza (CC-4176) \\
\hline \multirow[t]{3}{*}{ HCMEC } & $\begin{array}{l}\text { Microvascular } \\
\text { Endothelial Cell Growth } \\
\text { Kit-BBE }\end{array}$ & $A T C C \circledR P C S-110-040^{\mathrm{TM}}$ \\
\hline & $\begin{array}{l}\text { Vascular Cell Basal } \\
\text { Medium }\end{array}$ & ATCC® PCS-100-030 \\
\hline & Ciprofloxacino 10ug/mL & Sigma-Aldrich \\
\hline \multirow[t]{4}{*}{$\begin{array}{l}\text { Cardiomiocitos } \\
\text { primarios }\end{array}$} & $\begin{array}{l}\text { DMEM High Glucose } \\
4.5 \mathrm{mg} / \mathrm{mL} 75 \%\end{array}$ & Gibco-Invitrogen \\
\hline & M199 20\% & Gibco-Invitrogen \\
\hline & Horse Serum 5\% & Corning \\
\hline & Ciprofloxacino $10 \mu \mathrm{g} / \mathrm{mL}$ & Sigma-Aldrich \\
\hline \multirow[t]{3}{*}{ Fibroblastos Cardiacos } & DMEM/F12 & Gibco-Invitrogen \\
\hline & $10 \% \mathrm{FBS}$ & Corning \\
\hline & Ciprofloxacino $10 \mu \mathrm{g} / \mathrm{mL}$ & Sigma-Aldrich \\
\hline \multirow[t]{3}{*}{ MDA-MB-231 } & $\begin{array}{l}\text { DMEM High Glucose } \\
4,5 \mathrm{mg} / \mathrm{mL}\end{array}$ & Gibco-Invitrogen \\
\hline & FBS $10 \%$ & Corning \\
\hline & 10 ug/mL Ciprofloxacino & Sigma-Aldrich \\
\hline \multirow[t]{3}{*}{ MCF-7 } & $\begin{array}{l}\text { DMEM High Glucose } \\
4,5 \mathrm{mg} / \mathrm{mL}\end{array}$ & Gibco-Invitrogen \\
\hline & FBS $10 \%$ & Corning \\
\hline & $10 \mu \mathrm{g} / \mathrm{mL}$ Ciprofloxacino & Sigma-Aldrich \\
\hline
\end{tabular}




\subsection{Aislamiento de cardiomiocitos neonatales de rata}

Como modelo cardiaco in vitro se decidió utilizar los cardiomiocitos neonatales de rata NRCM. Para su extracción se llevó a cabo el siguiente modelo.

Las ratas recién nacidas con uno o dos días de vida son sacrificadas mediante decapitación, rápidamente el cuerpo es depositado en una cama de hielo. Se lleva a cabo un corte desde el cuello seccionado hasta la mitad del abdomen, por el cual se extrae el corazón del animal. El corazón se pone en medio HBSS 1x (GibcoInvitrogen) frío, se repite este proceso hasta que hemos extraído todos los corazones de los animales. Los corazones se lavan dos veces con HBSS frío para retirar toda la sangre o posibles contaminantes del medio. Después de esto retiramos, mediante el uso de unas tijeras o un bisturí, la parte de la aurícula de estos corazones para dejar solo la parte ventricular. Los corazones son posteriormente disgregados mediante un bisturí a tamaños entre $1-2 \mathrm{~mm}$ de tamaños. Una vez disgregados los corazones añadimos medio para una primera digestión compuesto por $8 \mathrm{~mL}$ de HBSS1x $+2 \mathrm{~mL}$ de Tripsina EDTA por cada 10 corazones aproximadamente. Esta digestión se mantiene durante 24 horas en agitación suave a $4^{\circ} \mathrm{C}$.

Al día siguiente nos preparamos para llevar a cabo a la segunda digestión de los cardiomiocitos. En primer lugar, preparamos $40 \mathrm{~mL}$ del medio de digestión, en este caso, las enzimas de digestión se basan en colagenasa II al 0.04\% (ThermoFisher Scientific) y DNAsa I al $0.02 \mathrm{mg} / \mathrm{mL}$ (ThermoFisher Scientific) disueltas en LeivobitzL15 (Gibco-Invitrogen, Carlsbad, CA). Este medio de digestión se calienta durante unos minutos en el baño a $37^{\circ} \mathrm{C}$. Mientras tanto, recuperamos los fragmentos de cardiomiocitos y los ponemos en un falcon de $50 \mathrm{~mL}$. Retiramos por aspiración todo el sobrenadante que se pueda de aquí y añadimos $10 \mathrm{~mL}$ del medio de digestión. Dejamos digerir los cardiomiocitos durante una primera digestión por 40 minutos a $37^{\circ} \mathrm{C}$ agitando cada cierto tiempo el falcon con los cardiomiocitos. Una vez pasados estos 40 minutos, agitamos suavemente la mezcla mediante aspiración con una pipeta de $25 \mathrm{~mL}$. Seguidamente, dejamos que sedimenten los fragmentos sin digerir durante unos minutos y recuperamos el sobrenadante. Este se pasa por un cellstrainer de $100 \mu \mathrm{m}$ para retirar todos los fragmentos no digeridos. La solución de digestión se detiene añadiendo el medio de preplaqueo que contiene una proporción 3:1 de DMEM alto en glucosa (4.5mg/mL)/M199 (ambos de Gibco, Grand Island, NY) suplementado con 15\% de FBS. Esta solución se centrifuga a 90Gs durante 5 minutos, el pellet se 
resuspende en este medio de preplaqueo y se siembra en placas de cultivo para permitir que los fibroblastos cardiacos se peguen mientras que los cardiomiocitos quedaran en el sobrenadante. Se repite el proceso de digestión de los fragmentos de cardiomiocitos hasta 3 veces más en digestiones de 20 minutos después de la primera. Una vez tenemos todo en preplaqueo incubamos las placas a $37^{\circ} \mathrm{C}$ durante 2 horas para permitir la adhesión de fibroblastos. Una vez ha pasado este tiempo juntamos todos los sobrenadantes y volvemos a centrifugarlos durante 5 minutos a $90 \mathrm{Gs}$. El sobrenadante se resuspende en el medio de los cardiomiocitos previamente especificado en la tabla. Estos se cuentan mediante una cámara Nuebauer y se siembran en una densidad de 150.000 células $/ \mathrm{cm}^{2}$ en placas previamente tratadas con gelatina al $0.1 \%$ (Invitrogen) durante 15 minutos a $37^{\circ} \mathrm{C}$. Después de varios días de cultivo los cardiomiocitos empiezan a latir de manera espontanea

\subsection{Medios de cultivo en condiciones de isquemia}

Para simular una isquemia es necesario que las células estén sometidas a un medio que le genere un daño por falta de nutrientes, así como por falta de oxígeno. Para ello se modelizó la isquemia de la siguiente manera. En primer lugar utilizamos un medio de cultivo sin apenas nutrientes (DMEM no glucose, no glutamine and no phenol red ThermoFisher Scintific) el cual tampoco se encuentra suplementado con suero. Es importante que el medio contenga sales de $\mathrm{Ca}^{2+} \mathrm{y} \mathrm{Mg}^{2+}$ ya que la incubación con un tampón carente de estas sales provocará que las células se despeguen del cultivo. Este medio es incubado sin células durante 24 horas en una atmósfera a $37^{\circ} \mathrm{C}$ y al $2 \%$ de oxígeno, esta incubación permitirá que el líquido equilibre su porcentaje de oxígeno con el de la atmósfera hipóxica.

A la hora de llevar a cabo el modelo de isquemia se les retira a las células el medio de cultivo estándar en el que se encuentren y se lavan 2 veces con PBS 1x para eliminar cualquier resto de nutrientes que pueda quedar remanente en la placa. Rápidamente se saca el medio de isquemia de la atmósfera sin oxígeno y se pone a las células. Estas células se incuban con el medio de isquemia durante 7 horas a $37^{\circ} \mathrm{C}$ en una atmósfera de oxígeno al $2 \%$.

\subsection{Infección de las células mesenquimales}

A continuación, se detalla el proceso por el cual modificamos genéticamente las células mesenquimales. 


\subsubsection{Transformación de bacterias}

Para este proceso se utilizó la cepa de bacterias competentes DH5 $\alpha$, bacterias que presentan una serie de mutaciones artificiales con el objetivo de mejorar su capacidad de transformación. En primer lugar, la mutación recA1 reemplaza un residuo de glicina por uno de ácido aspártico, lo cual desestabiliza la estructura de la recombinasa presente en la bacteria e impide la recombinación homóloga. La mutación endA1 inactiva las endonucleasas intracelulares lo cual previene la degradación del plásmido.

En primer lugar, se generan las placas en las que se siembran las bacterias. En este caso es necesario que tener en cuenta la resistencia a antibiótico que porta el plásmido en cuestión. Para ello se pesan 37.5 g de LB agar y se disuelven en un 1L de agua MQ. Seguidamente se autoclava la botella que contiene esta solución. Una vez autoclavada la mezcla esperamos a que la temperatura de la botella descienda a unos $50^{\circ} \mathrm{C}$. En este momento añadimos el antibiótico a una concentración especificada por el plásmido usado. Este medio se pone en placas Petri y se espera a que gelifique el LB agar. Una vez generadas las placas están pueden guardarse a $4{ }^{\circ} \mathrm{C}$ para su posterior uso. A continuación, se extraen las bacterias de su almacenamiento a $-80^{\circ} \mathrm{C}$ y se descongelan en hielo durante una hora. Después, a esta suspensión de bacterias se pone 2-3 $\mu \mathrm{g}$ del plásmido que se desea transformar y se mantienen durante $30 \mathrm{~min}-1$ hora a $37^{\circ} \mathrm{C}$. Tras este paso se realiza un shock térmico de $42^{\circ} \mathrm{C}$ durante 1 minuto tras el cual las bacterias se ponen en hielo durante 5 minutos. Después de este paso se añade $500 \mu \mathrm{L}$ de LB a las bacterias y se incuban a $37^{\circ} \mathrm{C}$ durante 1 hora con una agitación suave. Las bacterias se centrifugan a $3000 \mathrm{rpm}$ durante 5 minutos y el pellet se resuspende en $25 \mu \mathrm{L}$ de LB que se siembra por estría en las placas previamente preparadas. El cultivo se incuba a $37^{\circ} \mathrm{C}$ durante 24 horas donde solo crecerán aquellas bacterias que hayan interiorizado el plásmido en cuestión ya que este le aportará la resistencia a antibiótico que hemos puesto en las placas.

\subsubsection{Crecimiento bacteriano y aislamiento del plásmido}

Una vez tenemos nuestras bacterias transformadas seleccionamos de la placa bacteriana una colonia aislada de células y la picamos con una punta de pipeta estéril. Esta se lleva a un tubo con $10 \mathrm{~mL}$ de LB + antibiótico y se deja crecer durante 24 horas a $37^{\circ} \mathrm{C}$ para generar un inóculo que se utilizará en la maxi prep. Una vez tenemos crecido el inóculo lo añadimos sobre $300 \mathrm{~mL}$ de LB + antibiótico en cuestión y volvemos a dejar crecer durante 24 horas a $37^{\circ} \mathrm{C}$. Con las bacterias crecidas procedemos al aislamiento del plásmido mediante el kit de JetStar ${ }^{\mathrm{TM}} 2.0$ Plasmid 
Maxiprep Kit (Genomed). Una vez eluido el plásmido en cuestión este resuspende en agua y se cuantifica mediante el uso del Nanodrop 2000 (Thermofisher)

\subsubsection{Generación de los lentivirus}

Una vez que tenemos los plásmidos en cuestión que nos permitirán generar los lentivirus es necesario una línea de células empaquetadora que nos permita que estas células interioricen los plásmidos necesarios para empezar a generar los lentivirus. En este trabajo se utilizó como línea empaquetadora las células HEK-293T en las condiciones de cultivo previamente descritas. Un día antes de la transfección con los plásmidos se siembran 3p100 a una densidad de 6 millones de HEK-293T en cada placa. Al día siguiente se reemplaza este medio por un medio DMEM alto en glucosa $(4.5 \mathrm{mg} / \mathrm{mL})$ sin complementar con suero. Por otra parte, se genera el medio de transfección el cual lleva por cada p100 de células de HEK-293T los siguientes componentes en la siguiente tabla. Se mezclan todos los componentes salvo el HBS2x una vez mezclados le añadimos el HBS2x y burbujeamos el medio con la pipeta durante 30 segundos -1 minuto. Se añade esta solución sobre las células gota a gota tras lo cual agitamos suavemente la placa e incubamos las células a $37^{\circ} \mathrm{C}$ durante 8 horas. Tras estas 8 horas el medio de las HEK293T se cambia por un medio con suero en el cual permanecen durante 48 horas. Tras estas 48 horas de incubación, se retira el medio de estas células y se filtra a $40 \mathrm{~nm}$.

\begin{tabular}{|c|c|}
\hline Agua Estéril & $\mathbf{4 2 8 . 5} \boldsymbol{\mu L}$ \\
\hline Plásmido VSV o PMD2g & $1.5 \mu \mathrm{L}$ \\
\hline PAX2 & $3 \mu \mathrm{L}$ \\
\hline Vector & $5 \mu \mathrm{g}$ \\
\hline CaCl2 & $62 \mu \mathrm{L}$ \\
\hline HBS 2x & $500 \mu \mathrm{L}$ \\
\hline Cloroquina & $3 \mu \mathrm{L}$ \\
\hline
\end{tabular}

\subsubsection{Titulación del virus}

Una vez generados los lentivirus se congelan a una temperatura de $-80^{\circ} \mathrm{C}$ y se reservan $100 \mathrm{uL}$ del mismo para evaluar la cantidad de partículas infectivas que tenemos en nuestro medio. Para la titulación del virus volvemos a utilizar la línea HEK293T las cuales sembramos en una densidad de 20.000 células por pocillo de p24. Al día 
siguiente ponemos el $10 \mu \mathrm{L}$ de la alícuota de $100 \mu \mathrm{L}$ en uno de los pocillos y $90 \mu \mathrm{L}$ en otro. Estas cantidades nos permiten discernir la cantidad de partículas infectivas que tenemos sin temor a que nos pasemos o nos quedemos cortos de virus ya que si, por ejemplo, solo pusiéramos la cantidad de $90 \mu \mathrm{L}$ y esto produjera una infección del $100 \%$ de las células no sabremos la cantidad de partículas virales que tendríamos porque quizá en el momento de la infección hubiera partículas de sobra. Los virus se añaden en medio DMEM alto en glucosa sin suplementar con suero con una concentración añadida de polibreno al $0,1 \%$. Se incuban durante 8 horas tras las cuales se reemplaza el medio por DMEM alto en glucosa suplementado con FBS al $10 \%$. Una vez cambiado el medio dejamos incubar durante 48horas antes de evaluar el porcentaje de infección. En este caso el porcentaje de infección se evalua mediante resistencia a higromicina. Por ellos las células infectadas se dividen y parte de ellas se tratan con higromicina, la supervivencia de estas se compara con una de células no infectadas mediante una prueba como CCK8 o MTT.

\subsection{Transfección de células con miRNAs}

Este protocolo se utiliza para introducir de manera artificial una secuencia de miRNA en las células que se expresará durante un tiempo parcial en la misma. Para ello en primer lugar se cultivan las células de manera estándar hasta alcanzar una confluencia deseada. En el día siguiente se diluye la lipofectamina 3000 (ThermoFisher Scientific) en Opti-Mem Reduced Serum Media (ThermoFisher Scientific) y se mezcla bien. Por otro lado, preparamos el mimic de la secuencia a transfectar disuelto en optimem a la concentración de 40nM en la solución final. Se mezclan estos dos componentes y se espera durante 5 minutos hasta que se formen los liposomas. Este medio se añade sobre las células, después de este proceso esperamos 1 día para poder observar los efectos de la transfección en las células.

\section{$\underline{5 . A i s l a m i e n t o ~ d e ~ v e s i ́ c u l a s ~ e x t r a c e l u l a r e s ~}$}

Para el aislamiento de las vesículas extracelulares en primer lugar generamos el medio a partir del cual vamos a extraer estas vesículas. Es importante que este medio se encuentre libre de vesículas previas que nos contaminen las posteriormente extraídas. El principal agente que contiene las vesículas se encuentra en el FBS que se les añade a los medios, por este motivo el FBS se mezcla al 50\% con el medio de cultivo de la línea celular de la que se quieran obtener las vesículas y se centrifuga a 100.000 Gs 
durante 15 horas. Esta mezcla del FBS con medio de cultivo reduce la viscosidad del FBS y permite una mejor depleción de vesículas. Después recogemos el sobrenadante y lo filtramos a $0.2 \mu \mathrm{m}$ para retirar posibles contaminantes. Este FBS depletado se encuentra a la mitad de concentración que el FBS normal así que suplementamos los medios de extracción de exosomas con el $20 \%$ en lugar del $10 \%$.

Una vez las células se encuentran en confluencia del $80-90 \%$ se les retira el medio normal a las células, se lavan con PBS para retirar todo el posible medio con suero que puedan contener y se les pone el medio de extracción de exosomas (suplementado al $20 \%$ con suero depletado). Incubamos las células durante 48 horas con este medio de extracción. Seguidamente empezamos una serie de centrifugaciones secuenciales destinadas a la eliminación de contaminantes y aislamiento de las vesículas.

- En primer lugar, se lleva a cabo una centrifugación a 2.000Gs durante 25 minutos a $4{ }^{\circ} \mathrm{C}$. Esta centrifugación eliminar cualquier contaminante en forma de debrí celulares que pueda contener la muestra.

- Seguidamente se recoge el sobrenadante de estos tubos y se ponen en tubos de ultracentrifuga. Una vez equilibrados los tubos se colocan en un rotor de ángulo fijo (50.2Ti Beckman) y se centrifugan a 10.000RPM durante 1 hora. Después de esta centrifugación el sobrenadante se filtra a través de un filtro de tamaño de poro de $0.2 \mu \mathrm{m}$. Esta centrifugación elimina posibles contaminantes más pequeños que los precipitados en la centrifugación anterior además de seleccionar las vesículas que se encuentren por debajo del tamaño del poro.

- Se reparte la solución anteriormente filtrada en tubos de ultracentrifuga y se centrifugan a 100.000 Gs durante 2 horas a $4^{\circ} \mathrm{C}$. Después de ella retiramos con cuidado el sobrenadante y resuspendemos el pellet de cada uno de los tubos con $1 \mathrm{~mL}$ de PBS.

- Una vez resuspendidos se juntan todos los pellets correspondientes a cada condición en un solo tubo que se ultracentrifuga a 100.000 Gs durante 2 horas a $4^{\circ} \mathrm{C}$. El pellet se resuspende en $100 \mathrm{uL}$ de PBS frio.

\subsection{Caracterización de las vesículas}

Las vesículas se caracterizaron mediante 4 métodos diferentes

Western Blot: Como previamente se ha descrito, para ello se utilizaron los $\mathrm{Ab}$ característicos de exosomas: CD9,CD61, CD63, Alix y TSG101 
Microscopía electrónica: En este proceso las partículas aisladas se diluyen en PBS y se incluyen en rejillas recubiertas de carbono. Estas rejillas se contrastan con acetato de uranilo al $2 \%$ y son visualizadas mediante un microscopio electrónico de transmisión FEI Tecnai G2 Spirit. Las imágenes fueron adquiridas usando una cámara CCD Morada (Olympus Soft Image Solutions $\mathrm{GmbH}$ ). El tamaño de las vesículas fue cuantificado usando el software ImageJ. El diámetro de las vesículas se estimó mediante la medición de 25 vesículas en diferentes campos en 3 experimentos diferentes. Los procesos de microscopía electrónica se llevaron a cabo en el servicio de microscopía del Instituto de Investigación Príncipe Felipe (Valencia)

Nanotracking análisis: La distribución y cuantificación de las vesículas se llevó a cabo mediante un análisis de nanotracking (NTA) usando un NanoSight NS3000 (Malvern Instruments, UK) Las muestras se suspenden en PBS previamente filtrado a $0.22 \mu \mathrm{m}$ en diluciones de 1:1000 o 1:500 hasta alcanzar una concentración de partículas entre $2 \times 10^{8-9}$ particulas $/ \mathrm{mL}$. Las medidas del diámetro se hicieron a partir de 3 experimentos independientes y se muestra las medidas de moda \pm desviación estándar. El estudio de NTA se llevó a cabo en el servicio de análisis de vesículas del Instituto de Investigación Príncipe Felipe

Inmunogold: En este proceso las vesículas se fijan a rejillas recubiertas de carbono como en el caso de la visualización directa con microscopia electrónica. Estas rejillas se sumergen en buffer de bloqueo durante una hora. Estas rejillas se incuban seguidamente overnight con el anticuerpo primario a $4^{\circ} \mathrm{C}$ (anti-Human -CD63 1:10 Abcam). Como controles se utilizado rejillas sin exponer a la incubación con el anticuerpo primario. El día siguiente las rejillas se sumergen en PBS y después se colocan en gotas de IgA conjugada con partículas de oro de 10nm (AURION, Hatfield, PA) durante 1 hora a temperatura ambiente. Las rejillas fueron luego lavadas con PBS y puestas en una solución de $1 \%$ de glutaraldehído en $0.1 \mathrm{M}$ de buffer fosfato durante 15 minutos. Después de esto se lavan las rejillas en PBS y agua destilada y se contrastan en una mezcla de $2 \%$ metil celulosa y $1 \%$ de acetato de uranilo. Las rejillas se examinan en un microscopio electrónico de transmisión Tecnai G2 Spirit (FEI, Europe, Eindhoven, NT) y las imágenes se toman mediante una cámara CCD Morada (Olympus Soft Image Solutions GmbH). Los procesos de inmunogold se llevaron a cabo en el servicio de microscopía del Instituto de Investigación Príncipe Felipe (Valencia) 


\subsection{Electroporación de vesículas}

La electroporación de vesículas para introducir un miRNA se llevó cabo mediante el siguiente protocolo. Este proceso se lleva a cabo entre la penúltima centrifugación y la última. Una vez hemos aspirado el sobrenadante de la primera centrifugación a 100.000Gs los pellets se resuspenden en $100 \mu \mathrm{L}$ de Buffer de electroporación después se añade el mimic en una concentración de $40 \mathrm{nM}$ a la solución de electroporación. Esta mezcla se coloca en una cubeta de electroporación (MicroPulser Electroporation Cuvettes, Biorad) la cual es sometida a 3 pulsos de $300 \mathrm{~V}$ espaciados por un intervalo de 5 segundo entre ellos en un generador de corriente Gene Pulser Xcell Electroporation Systems (Biorad). Después de esto las vesículas se mantienen en hielo durante 15-20 minutos tras los cuales se lleva a cabo la siguiente ultracentrifugación. El resultante de la electroporación se diluye hasta el contenido de un tubo de ultracentrifuga $(24 \mathrm{~mL})$ y se centrifuga a 100.000 Gs durante dos horas. Tras lo cual aspiramos el sobrenadante y resuspendemos en $100 \mu \mathrm{L}$ de PBS, de esta manera se concentran las vesículas y eliminan a su vez la mayor parte del miRNA no introducido en las vesículas.

Después de recibir un proceso de electroporación se comprueba la integridad de las vesículas por microscopía electrónica y NTA.

\section{$\underline{\text { 6.Ensayos en modelos celulares }}$}

\subsection{Ensayo de captación de vesículas}

Para este procedimiento se marcaron con una partícula fluorescente los exosomas. Las vesículas se marcaron con succinimidil diester carboxifluoresceina acetato (CFSE Thermo Fisher Scientific) a una concentración de $5 \mu \mathrm{M}$ durante 15 minutos a $37^{\circ} \mathrm{C}$. Seguidamente se lleva a cabo una ultracentrifugación a 100.000 Gs durante 2 horas a $4^{\circ} \mathrm{C}$ tras el cual se resuspenden las vesículas teñidas en $100 \mu \mathrm{L}$ de PBS estéril. Como control se utilizó la misma cantidad de CFSE añadida sobre PBS estéril para comprobar la cantidad de CFSE sin incorporar que se arrastra en el proceso. Una vez tenemos las vesículas teñidas se siembran las células a un $50 \%$ de confluencia en pocillos de 24 pocillos a los que se añade estas vesículas previamente cuantificadas a una concentración de $2 \mu \mathrm{g} / \mathrm{mL}$ (unas $5 \times 10^{8}$ particulas $/ \mathrm{mL}$ ). Después de 3 horas de incubación de las células con las partículas se calculó mediante citometría de flujo 
(FACS Canto II) la cantidad de células positivas para la fluorescencia a 495nm en comparación con el control previamente mencionado.

\subsection{Ensayo de estrés oxidativo}

Para este experimento se usó el reactivo CellRox®(ThermoFischer Scientific), este reactivo reacciona con las especies reactivas de oxígeno presentes en la célula y origina una señal fluorescente de intensidad proporcional a la cantidad de ROS presente en la célula. Para este experimento las células se cultivaron en condiciones de isquemia previamente descritas o sometidas al tratamiento con doxorrubicina. Después del tiempo de tratamiento isquémico o con la doxorrubicina se retira el medio de estas células y se lavan con PBS. Seguidamente se añade el medio de las células sin suero con una concentración de $0,5 \%$ de Cell Rox. Se mantienen a $37^{\circ} \mathrm{C}$ durante 20 minutos. Tras este tiempo se aspira el medio y se lavan 3 veces con PBS las células para retirar todo el posible marcador que no se haya incorporado a las células. Seguidamente se tripsinizan las células y se cuantifica la intensidad de fluorescencia a $660 \mathrm{~nm}$. Como control se utilizaron células que no han sido sometidas a estrés por doxorrubicina o isquemia y células no teñidas.

\subsection{Ensayo de Captación de Doxorrubicina}

Con el objetivo de conocer la cantidad de doxorrubicina que se presenta dentro de la célula, se midió la fluorescencia de la propia doxorrubicina. Esta molécula posee una fuerte fluorescencia a una longitud de onda de $595 \mathrm{~nm}$ tras una excitación a 495nm. Por lo que para la estimación de la concentración de doxorrubicina se añadieron concentraciones crecientes de doxorrubicina a una línea celular de cardiomiocitos primaros. Y se midió su absorbancia a $595 \mathrm{~nm}$ tras 48 horas de incubación. Con esto datos se realizó un análisis de regresión lineal con el cual se puede calcular la cantidad residual de doxorrubicina que existe en las células mediante su absorbancia a $595 \mathrm{~nm}$.

\subsection{Ensayo de formación de tubos}

Este ensayo in vitro nos da una idea de la capacidad angiogénica del compuesto que queramos tratar. En el caso de comprobar el efecto de un miRNA las células endoteliales (HUVEC) se transfectaron a una concentración de 20nM un día previo al experimento mientras que, en el caso de las vesículas, estas se pusieron a una concentración de $15 \mu \mathrm{g} / \mathrm{mL}$ durante el tratamiento de estrés (doxorrubicina e isquemia). 
Después de este tratamiento, las células se tripsinizan y se cuantifican. Se sembraron $1,2 \times 10^{\wedge} 4$ células en un pocillo de p96 previamente tratado con $50 \mu \mathrm{L}$ de Matrigel reducido en factores de crecimiento (BD Biosciences). En el caso del protocolo de isquemia las células endoteliales se siembran en un medio sin apenas nutrientes (DMEM sin glucosa 1\% de FBS) para simular un proceso de isquemia leve. Seguidamente se tomaron las imágenes de la formación de estructuras tubulares formadas en el Matrigel 6 horas después de ser sembradas mediante un microscopio invertido (Leica DM 6000) a un aumento de 10x. Las estructuras tubulares se cuantificaron mediante el software online WimTube (WimTube: Tube Formation AssayImage Analysis Solution. Release 4.0. https://www.wimasis.com/en/WimTube).

\subsection{Ensayo de CCK8}

Este ensayo tiene como objetivo determinar el número de células viables que se encuentran en el cultivo. Para ello, las células una vez tratadas con los diversos tratamientos son cultivadas durante 4 horas con el medio de cultivo suplementado al $10 \%$ con el reactivo CCK8® (Cell Counting Kit 8, ThermoFisher Scientific). Este genera en el medio una coloración anaranjada en el medio de cuya absorbancia a 460nm es proporcional al número de células viables.

\subsection{Ensayo de Anexina por citometría de flujo}

El ensayo de Anexina V (BD Bioscience) es usado para determinar el porcentaje de celular de una población que se encuentran en un estado de apoptosis activa. Se basa en el hecho de que las células en estado de apoptosis cambian la configuración del lípido de membrana fosfatidil serina (PS) de manera intracelular a extracelular. A su vez, se añade ioduro de propidio (IP) que es capaz de pasar por membranas dañadas de células que se encuentran en necrosis. Para este protocolo se recoge el medio donde se encuentren cultivadas las células, se tripsinizan y se juntan con el medio recogido ya que en este pueden encontrarse células despegadas del plástico. Este medio se centrifuga y se resuspende en $100 \mu \mathrm{L}$ medio de anexina V 1x con 5uL de Anexina y $5 \mu \mathrm{L}$ de IP. Las células se dejan incubando en oscuridad durante 15 minutos a temperatura ambiente. Seguidamente se añaden $200 \mu \mathrm{L}$ de Buffer de Anexina 1x y se cuantifican el porcentaje de células positivas a $495 \mathrm{~nm}$ (Anexina V) y a 550 (IP) por citometría de flujo en un Facs Canto II (BD Bioscience) 


\subsection{Ensayo de Wound Healing in vitro}

Este ensayo se llevó a cabo para medir la capacidad de migración existente en poblaciones de fibroblastos. Para ello se siembran los fibroblastos a una alta densidad en un pocillo de 24 pocillos Al día siguiente, mediante una punta de pipeta de $10 \mu \mathrm{L}$ se realiza una raya vertical en el cultivo. Seguidamente mediante un microscopio óptico invertido (Leica DM6000) se toman las imágenes y se marca en la parte inferior de la placa el punto donde se adquiere la imagen. Se fueron tomando imágenes en intervalos de 2 horas en el mismo punto donde se llevó a cabo la primera imagen. El área que queda en el medio se cuantifica mediante el uso de la herramienta informática ImageJ

\section{$\underline{\text { 7.Modelos animales }}$}

\subsection{Modelo de infarto mediante ligadura permanente}

Para este modelo se usaron ratas macho de la cepa Wistar de entre 5-8 semanas de vida con un peso aproximado de 250-300 gramos. Las ratas que se sometieron a la operación fueron sedadas con sevofluarano a una concentración de $5 \%$ en una cámara estanca. Una vez se encuentran bien sedadas se sacan de la cámara y se procede a la intubación del animal. Una vez que comprobamos que se encuentra bien intubada la cánula se conecta a un respirador de oxígeno a un flujo de 100 ventilaciones por minuto y 2.5 de volumen con un porcentaje de sevofluorano del $4.5 \%$. Observamos que el ritmo de respiración del animal coincide con el del respirador y el volumen de sevofluorano se ajusta a un nivel de $3.5 \%$. Una vez en este punto se coloca a la rata sobre su costado derecho y se fija para evitar movimientos a la superficie de operación. Se rasura la zona del costado izquierdo del animal y se limpia el área con etanol y seguidamente con betadine. En este punto antes de realizar la operación se le inyecta a la rata de manera intraperitoneal una dosis de Fentanilo al $20 \%$ en suero fisiológico. Mediante el uso de unas pinzas y tijeras quirúrgicas se van abriendo capas musculares hasta llegar a las costillas. En este punto se evalúa la altura del corte y se realiza una incisión entre dos costillas con cuidado de no tocar el pulmón que esta debajo. Una vez abiertas las costillas se puede observar el corazón del animal. Se retira mediante el uso de unas pinzas el pericardio del animal. A continuación, pasamos a visualizar la arteria coronaria situada desde la parte de superior cerca de la orejuela y haciendo un recorrido en dirección hacia el ápex del corazón. Una vez localizada, se pasa una aguja con una seda de tamaño de 6/0 pinchando una parte superficial del musculo cardiaco y se liga la arteria mediante dos nudos simples. Se comprueba que se ha realizado bien 
la operación cuando aparece un cambio en la coloración del músculo cardiaco. Es de vital importancia realizar a la misma altura la ligación ya que una altura de ligación demasiado alta puede provocar que el infarto sea demasiado grande mientras que una ligación demasiado baja puede dar lugar a un infarto muy pequeño.

Una vez inyectado el compuesto a testar, se procede a cerrar el animal, en primer lugar, las costillas y seguidamente los distintos planos musculares mediante una sutura monofilamente de 3/0. Para la piel se utiliza una sutura intradérmica también con un monofilamento 3/0. Una vez terminada la operación se le inyecta al animal un Buprex a una concentración de $20 \%$ en suero fisiológico y se retira la anestesia inhalada por sevofluorano manteniendo la respiración con oxigeno durante unos minutos.

\subsection{Ecocardiografía de ratas nude}

La ecocardiografía nos permite la evaluación y seguimiento de las ratas infartadas pudiendo medir una serie de parámetros para comprobar la función cardiaca. Previamente, las ratas son anestesiadas mediante una anestesia inhalatoria (Sevofluorano). Seguidamente se miden los parámetros mediante un sistema ecocardiográfico (General Electrics) equipado con una sonda de 10MHz. Las medidas se toman antes de la cirugía y 4 semanas después. Se miden los parámetros de ventrículo izquierdo en diástole (VIDd) y ventrículo izquierdo en sístole (VIDs), el grosor de la pared anterior y posterior (PA, PP) en diástole y sístole, y el área diastólica final (ADF) y área sistólica final (ASF). El cambio porcentual de área se midio mediante la formula [(ADF-ASF)/ADF]x100. La fracción de acortamiento (FA) se midió mediante la fórmula [(VIDd-VIDs)VIDd]x100. Los cambios en la pared posterior se midieron como[(PAs-PPd)/PPd]x 100

\subsection{Sacrifico y fijación del corazón}

Una vez pasan 15 días después del procedimiento quirúrgico, se procede al sacrificio del animal para extraer el corazón. En primer lugar, se inyecta al animal $0.5 \mathrm{~mL}$ de Tiopental de manera intraperitoneal a la rata y se deja que haga efecto. Una vez que se comprueba que la rata no responde a estímulos en una pata se procede a abrir la cavidad torácica del animal hasta dejar el corazón visible. Se inyecta una palometa por un lado la vena porta cava inferior del animal mientras que por otro lado se inyecta otra en el ápex del corazón. Una vez colocadas las cánulas se para un volumen por ambas de 5 $\mathrm{mL}$ de una solución de cloruro de cadmio $(\mathrm{CdCl})$ para parar el corazón en diastolia. Una vez pasado este volumen se retira la canulación de la cava y se corta. 
Seguidamente se pasa un volumen de $10 \mathrm{~mL}$ de suero salino por la canulación del ápex, seguidamente se inyectan $5 \mathrm{~mL}$ de PFA al $2 \%$. Una vez terminado se retira la palometa del ápex e introducimos otra por la aorta por la que se pasara PFA al 2\% durante 15 minutos a una velocidad de $4,3 \mathrm{~mL} / \mathrm{min}$. Una vez pasado este volumen se saca el corazón y se hace un lavado con PBS. Se corta un poco de aurícula y de ápex para favorecer la penetración del PFA. Después se dejan a $4^{\circ} \mathrm{C}$ en PFA en agitación durante toda la noche para el día siguiente hacer 5 lavados de PB 0,1M durante 15 minutos.

\subsection{Inyección de doxorrubicina}

En este experimento se determinó la cantidad potencialmente letal de doxorrubicina en ratones, para ello se utilizó la cepa c57B1J de ratones. Se compararon inyecciones de doxorrubicina de $15 \mathrm{mg} / \mathrm{kg}$ en una sola inyección o 2 inyecciones con $7.5 \mathrm{mg} / \mathrm{kg}$ separadas por una semana de duración. En otro grupo de animales se estudió el efecto protector de las EVs frente a la doxorrubicina. Para ello se inyectaron $15 \mathrm{mg} / \mathrm{kg}$ de doxorubicina a 4 animales y se compararon con un grupo a los cuales se les inyecto la misma dosis de doxorrubicina y una cantidad de $30 \mu \mathrm{g}$ de EVs. El peso de los ratones se fue monitorizando cada dos días, durante 15 días. Para finalizar el experimento los animales fueron sacrificados por sobredosis de tiopental.

\subsection{Modelo de angiogénesis in vivo mediante Plug de Matrigel}

Para comprobar la capacidad angiogénica de un componente en un modelo in vivo se llevó a cabo el modelo de plug en matrigel. Para ello se midieron los vasos producidos en una inyección de matrigel subcutánea. Se inyectan $350 \mu \mathrm{L}$ de Matrigel líquido a $4^{\circ} \mathrm{C}$, en este matrigel se pueden inyectaron también un total de $20 \mu \mathrm{g}$ de mimic del miRNA miR-4732-3p o 20 $\mu \mathrm{g}$ de mimic NC. Como control positivo se mezclaron FGF en el matrigel con heparina a una concentración de $100 \mathrm{ng} / \mathrm{mL}$ y $20 \mathrm{U}$ respectivamente. Se añadió un segundo control negativo de PBS al matrigel. El matrigel se inyecto en los flancos de ratones atímicos de entre 6 y 8 semanas. Después de 14 días los ratones fueron sacrificados y los plugs fijados a una concentración de PFA del $4 \%$ en PBS. Una vez fijados los plugs se embeben en parafina y son cortados y teñidos para comprobar la presencia de CD31. 


\subsection{Histoquímica}

\subsubsection{Parafinización del tejido}

Una vez tenemos fijado el tejido se procede a su parafinización para poder cortarlo. Para ello las muestras de tejido se someten al siguiente protocolo:

- Etanol al 70\% overnight en agitación de $225 \mathrm{rpm}$.

- Etanol al 70\% durante una hora.

- Dos lavados de etanol al $96 \%$ durante 1 hora cada uno.

- Dos lavados de etanol 100\% durante 1 hora cada uno.

- Dos lavados de Xilol durante 30 minutos cada uno.

- Mantener el tejido en parafina "sucia" durante 1 hora.

- Pasar el tejido a parafina limpia donde se incluyen en los cassettes.

\subsubsection{Desparafinación del tejido}

Una vez cortado el tejido a las micras deseadas procedemos a la desparafinización del tejido. Para ello se sigue el siguiente protocolo:

- Se mantienen los cortes en estufa a $60^{\circ} \mathrm{C}$ durante 25 minutos.

- Se pasan por xilol dos veces durante 5 minutos.

- Dos lavados de etanol al $100 \%$ durante 5 minutos.

- Un lavado con etanol $96 \%$ durante 5 minutos.

- Un lavado con etanol $70 \%$ durante 5 minutos.

- Mantener en agua destilada hasta empezar la tinción.

\subsubsection{Tricrómico de Mason}

Para esta tinción se siguió el siguiente protocolo una vez desparafinado el tejido y mantenido en agua destilada.

- Introducir los portas en el cestillo en un baño previamente calentado a $56^{\circ} \mathrm{C}$ en solución de Bouin (Sigma Aldrich).

- Se lavan con agua corriente hasta enfriar las muestras.

- Dos incubaciones en Hematoxilina férrica (Sigma Aldrich) de 5 minutos cada uno. 
- Vamos reduciendo la temperatura progresivamente mediante 3 baños de agua corriento calentada previamente .

- Aclaramos los tejidos con agua destilada.

- Se trata los cortes durante 2 minutos con Fucsina ácida-escarlata de biebrich (Sigma HT15).

- Aclaramos con agua destilada.

- Tratamos con ácido fosfomolíbdio durante 15 minutos (sigma HT15).

- Incubamos durante 1 minuto con azul de anilina (Sigma HT15).

- Incubamos durante 1 minuto con ácido acético glacial al $1 \%$.

- 20 pases de etanol al $7 \%$.

- 20 pases en etanol $96 \%$.

- 20 pases en etanol $100 \%$.

- Se mantiene hasta el montaje en xilol.

\subsubsection{Rojo Sirio}

Para esta tinción se siguió el siguiente protocolo una vez desparafinado el tejido y mantenido en agua destilada.

- Preparación del Rojo Sirio

- Mezclamos $4 \mathrm{~g}$ de Pícrico saturado con $90 \mathrm{~mL}$ de agua destilada y agitar durante 30 minutos

- Pesamos 0,1g de Direct Red y disolvemos en $10 \mathrm{~mL}$ de agua,

- Mezclamos ambas disoulciones y esperamos 48 horas

- Filtrar en el momento de usar.

- Incubar las muestras con rojo sirio a temperatura ambiente durante 30 minutos.

- Realizamos dos lavados en agua acética.

- Dos lavados en etanol absoluto.

- Dos lavados en xilol .

- Se mantiene hasta el montaje en xilol. 


\section{RESULTADOS}




\section{Estudio de la comunicación intercelular cardiaca}

En primer lugar, en este estudio se comprobaron como las células cardiacas utilizan las vesículas para establecer una comunicación activa con las diferentes poblaciones cardiacas e incluso consigo mismas. Estas vesículas son a su vez, dependientes del estado en el que se encuentre el tejido cardiaco en ese momento, lo que permite una comunicación diferencial en función de las necesidades del momento en concreto. Para demostrar esta proposición, en este primer apartado de este trabajo, se aislaron vesículas extracelulares provenientes de cardiomiocitos y se estudiaron sus efectos en diferentes condiciones experimentales

\subsection{Aislamiento y caracterización de vesículas en cardiomiocitos}

Con el objetivo de estudiar con detalle el papel de las vesículas extracelulares derivadas de cardiomiocitos en la patología isquémica se utilizó la línea de cardiomiocitos humanos inmortalizados AC10 cultivada en Dulbecco's Modified Eagles's Medium F-12 suplementada con FBS al 10\%. Estas células se mantuvieron en condiciones de Normoxia $(\mathrm{Nx})$ y de Hipoxia (Hx) durante 48 horas tras las cuales se recogió el medio de cultivo y se ultracentrifugó para la extracción de vesículas. Las vesículas se caracterizaron por medio de los métodos de microscopía electrónica, NTA y western blot.
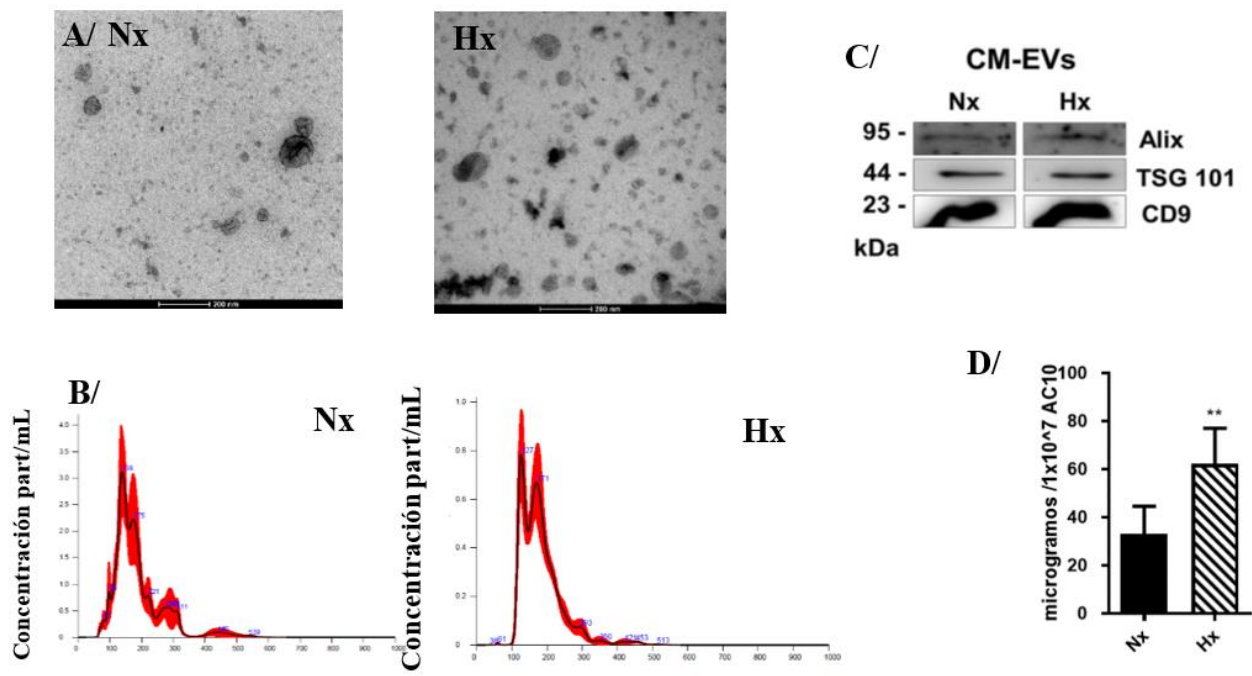

Tamaño (nm)

Tamaño (nm)

Figura 1: Caracterización de las EVs derivadas de la línea AC10. A) Imágenes representativas obtenidas por microscopia electrónica de las muestras de EVs en Normoxia $(\mathrm{Nx})$ e Hipoxia $(\mathrm{Hx})(\mathrm{n}=3$ barra de escala= 200 nm).B) Gráficas representativas de análisis por nanotracking de la distribución por tamaños mostrada por los aislamientos de EVs en Nx e Hx. Los ejes muestran el tamaño en nm frente a la concentración en partículas/mL $(n=3)$ C) Imágenes representativas del análisis por WB de los marcadores característicos de las EVs en condiciones de $\mathrm{Nx}$ e $\mathrm{Hx}(\mathrm{n}=3)$. D) Cuantificaciones de partículas calculadas por análisis de BCA. $(\mathrm{n}=3$, $* * p<0.01)$ 
Como se aprecia en la figura no existen fuertes diferencias morfológicas en el examen por microscopía electrónica donde pueden visualizarse vesículas con un tamaño en torno a los $100 \mathrm{~nm}$. El examen por NTA indica una moda en las vesículas obtenidas en condiciones de normoxia de $138 \mathrm{~nm}$ mientras que en hipoxia se encuentra en 127 . Los marcadores propios de vesículas extracelulares estudiados en este tipo de vesículas se muestran en ambas con similar cantidad. Respecto a la producción de vesículas se puede observar en cuantificaciones mediante BCA, que la cantidad de EVs producidas por los cardiomiocitos en condiciones de hipoxia se encuentra elevada hasta casi triplicar su producción en condiciones basales.

\subsubsection{Caracterización del contenido de las vesículas}

Una vez caracterizadas las vesículas de esta línea celular nos centramos en descubrir las proteínas diferencialmente expresadas entre ambas. Para este estudio se utilizó la técnica de espectroscopia de masas en tándem con cromatografía líquida (LCMS/MS). A partir de $30 \mu \mathrm{g}$ de proteínas de exosomas a los que previamente se eliminan componentes mayoritarios que pueden dificultar el estudio como son la albúmina sérica, por ejemplo. El estudio de las vesículas en Normoxia detectó un total de 53 proteínas mientras que en condiciones de hipoxia fueron 99. Entre las proteínas encontradas en las condiciones de hipoxia 64 de estas fueron específicas de la condición hipóxica. Se encontraron proteínas cardioprotectoras como NRP1 o Dkk1, proteínas relacionadas con el estrés celular como ATPcitrato sintasa, ácido graso sintasa y proteínas pro-apoptóticas. 

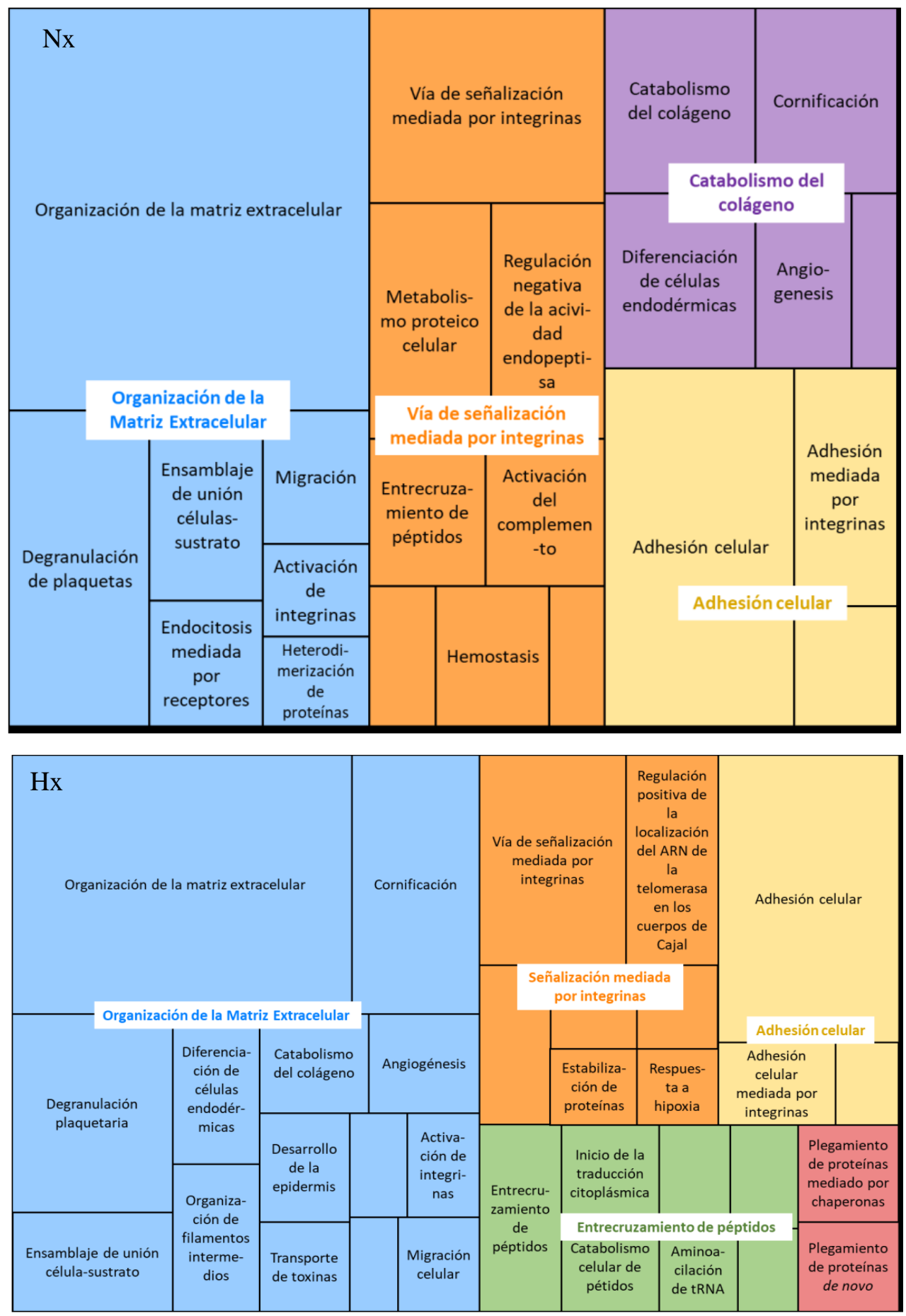

Figura 2: Diagramas Treemap de los procesos biológicos en EVs derivadas de CM en estados de Nx e Hx. Los diagramas se han llevado a cabo usando REVIGO después del análisis proteómico. Los códigos de colores indican organización de la matriz extracelular (azul), señalización mediada por integrinas (naranja) catabolismo del colágeno (morado), adhesión celular (amarillo), entrecruzamiento de péptidos (verde), plegamiento proteico (rojo) 
Los treemaps muestran los procesos biológicos y rutas afectadas por las proteínas encontradas en dichas vesículas. Como puede observarse las vesículas derivadas de cardiomiocitos en Nx tienen una mayor carga en proteínas involucradas en la regulación de la matriz extracelular, migración, metabolismo del colágeno etc. Mientras que las proteínas que se encontraban sobreexpresadas en condiciones de $\mathrm{Hx}$ vs $\mathrm{Nx}$ podemos ver un aumento en procesos biológicos relacionados con el plegamiento de proteínas, síntesis de proteínas, entrecruzamiento de péptidos etc lo cual implica que el contenido de las vesículas cambia en consecuencia del estado celular haciendo que estas vesículas se encuentren con una mayor concentración de proteínas orientadas a la resolución del estado patológico que se origine en ese momento. Vemos que estas vesículas tienen incrementada la concentración de proteínas orientado a la organización extracelular, así como de chaperonas. Estas proteínas son de vital importancia en eventos de hipoxia cardiaca ya que es necesario una respuesta rápida por parte de los cardiomiocitos y los fibroblastos cardiacas a la hora de cerrar una posible lesión que ocurra en el corazón.

\subsection{Las vesículas de AC10 en condiciones de Hipoxia y Normoxia no tienen efecto en la multiplicación en líneas celulares cardiacas.}

A raíz de los resultados anteriores, en los cuales se demuestra que las vesículas aumentan su concentración en proteínas involucradas en la matriz extracelulares y otras proteínas importantes cuando se segregan en estado de Hx, nos preguntamos si estas vesículas también serían capaces de inducir un aumento en la proliferación de las diferentes poblaciones cardiacas. Para ello se testó por test de CCK8 si la adicción de una concentración conocida de partículas de $\mathrm{Nx}$ e Hx generaban un aumento en la proliferación. En las diferentes poblaciones celulares se observó que la adicción de EVs no genera efectos de sobrecrecimiento ni tampoco reducen la tasa de proliferación celular. Estos resultados parecen apuntar al hecho de que las vesículas actúan modificando a la actividad de las células ya presentes en lugar de a efectos de aumento de la proliferación. 

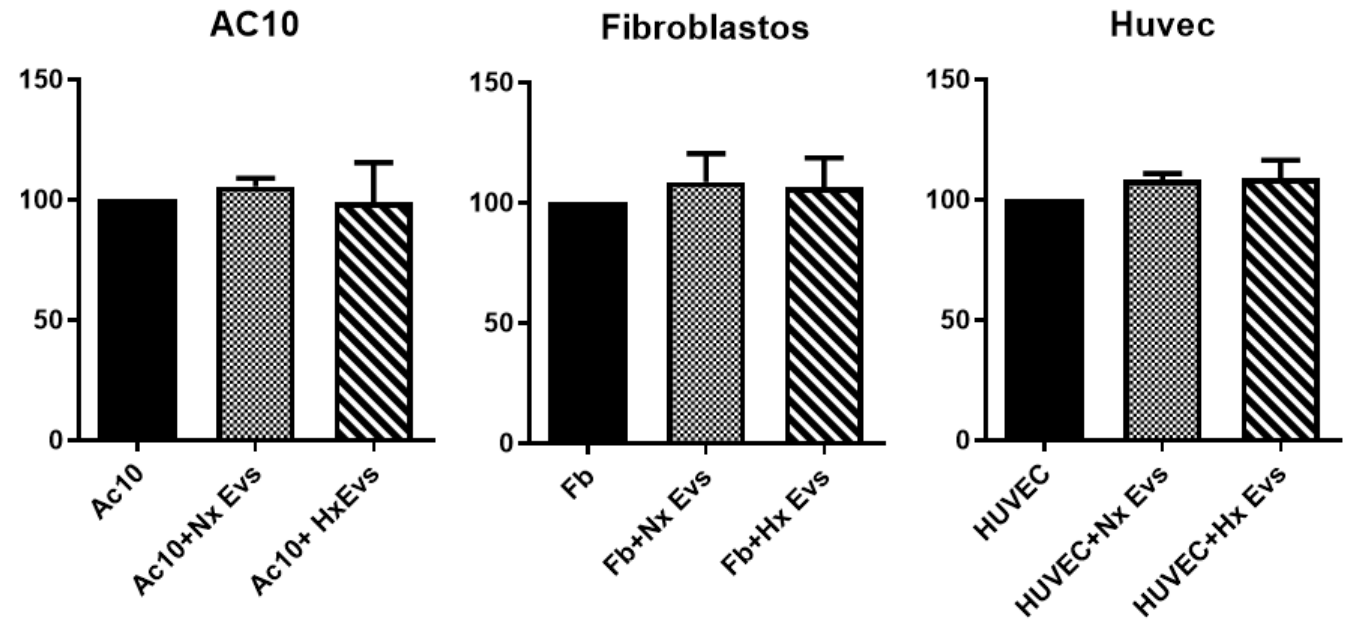

Figura 3: Experimentos de proliferación usando el kit comercial CCK8. Los resultados muestran que la adición de EVs a concentración de $30 \mu \mathrm{g} / \mathrm{mL}$ durante 24 horas no generan efectos proliferativos en las 3 líneas celulares AC10, Fibroblastos y HUVEC. $(n=3)$

\subsection{Las vesículas derivadas de cardiomiocitos en hipoxia son captadas preferencialmente en endotelio}

Este experimento nos permite conocer si las vesículas que provienen de células que se encuentran en un ambiente de hipoxia son más o menos propensas a ser captadas por otros tipos celulares. Para este experimento se marcaron las vesículas tanto de hipoxia como de normoxia con el reactivo CFSE que una vez es captado por la célula e internalizado genera una fluorescencia medible a $525 \mathrm{~nm}$ de longitud de onda. Como control negativo del experimento se utilizó $100 \mu \mathrm{L}$ de PBS que fueron sometidos al mismo proceso de tinción que las EVs. Una vez marcadas las vesículas se añadieron a las diferentes poblaciones celulares a una concentración de $15 \mu \mathrm{g} / \mathrm{mL}$ y se examinó su fluorescencia pasadas 3 horas. Los resultados demuestran que las células endoteliales son capaces de adquirir las vesículas extracelulares de manera preferencial si las comparamos con los fibroblastos. A su vez, podemos ver que no existe una captación preferencial entre las vesículas derivadas de cardiomiocitos en hipoxia frente a los de normoxia. Este resultado nos permite hipotetizar que no se produce un cambio sustancial en las proteínas de membrana de las vesículas extracelulares responsables de la unión a las células para su posterior captación cuando las vesículas provienen de células en estado hipóxico. Además, el hecho de que las células endoteliales tengan una mayor capacidad de captación de vesículas que los fibroblastos indica que se trata de un proceso que no se produce de manera pasiva, lo cual quiere decir que las partículas están siendo captadas por una serie de mecanismos concretos. 


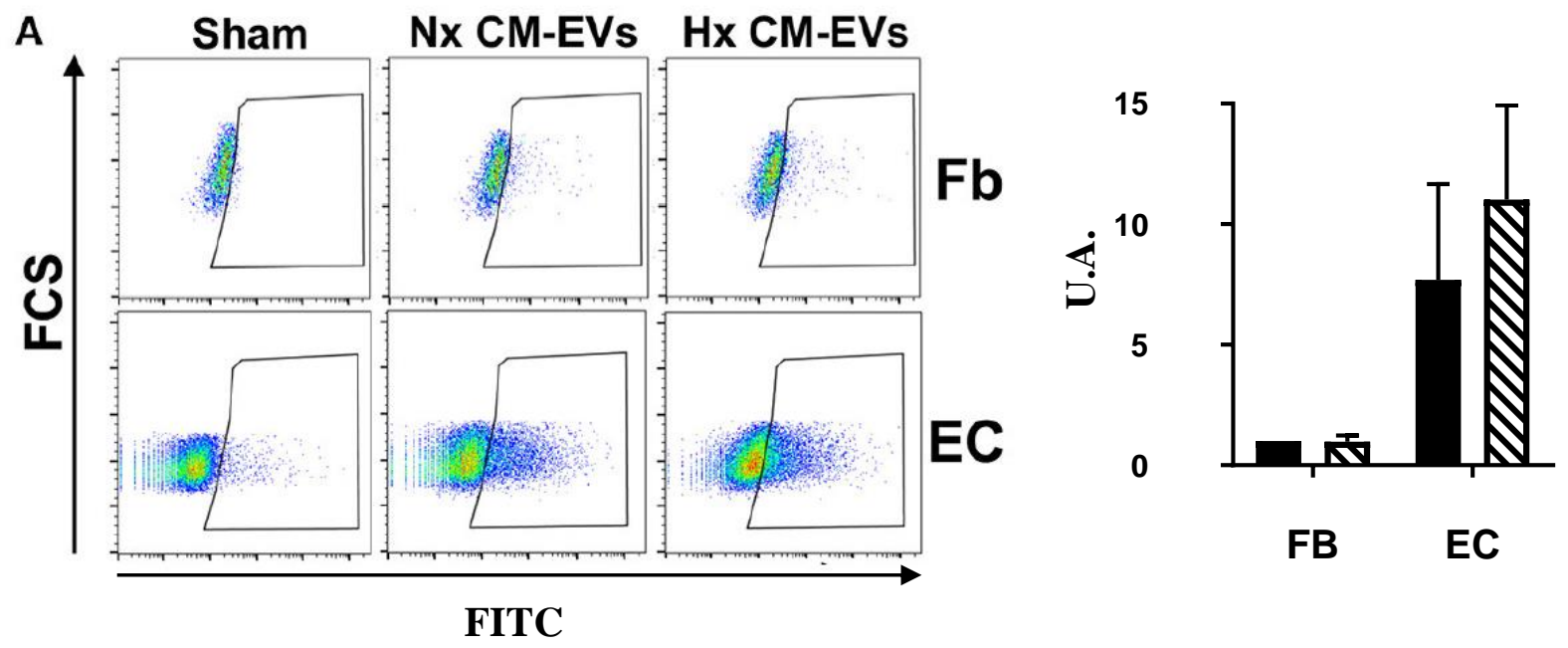

Figura 4: Experimento de captación de vesículas por parte de fibroblastos y células endoteliales. A) Diagramas representativos de citometría de flujo en el que se representa las células que adquieren la fluorescencia de las EVs marcadas con CFSE después de haberlas captado. B) Representación gráfica de la captación de fluorescencia de fibroblastos (Fb), y células endoteliales (EC). (U.A= unidades arbitrarias)

\subsection{Las vesículas derivadas de AC10 en Normoxia inducen un efecto angiogénico sobre las derivadas en hipoxia}

Para evaluar esto se utilizó la línea celular endotelial HUVEC. Las células se sembraron en Matrigel ${ }^{\circledR}$ mientras que a la vez se le añade las EVs derivadas de ambas condiciones a una concentración de $15 \mu \mathrm{g} / \mathrm{mL}$. Las imágenes de las formaciones tubulares generadas por estas células endoteliales se tomaron después de pasadas 8 horas en las que puede observarse una menor cantidad de formaciones ramificadas en aquellas células tratadas con EVs derivadas de AC10 en hipoxia.
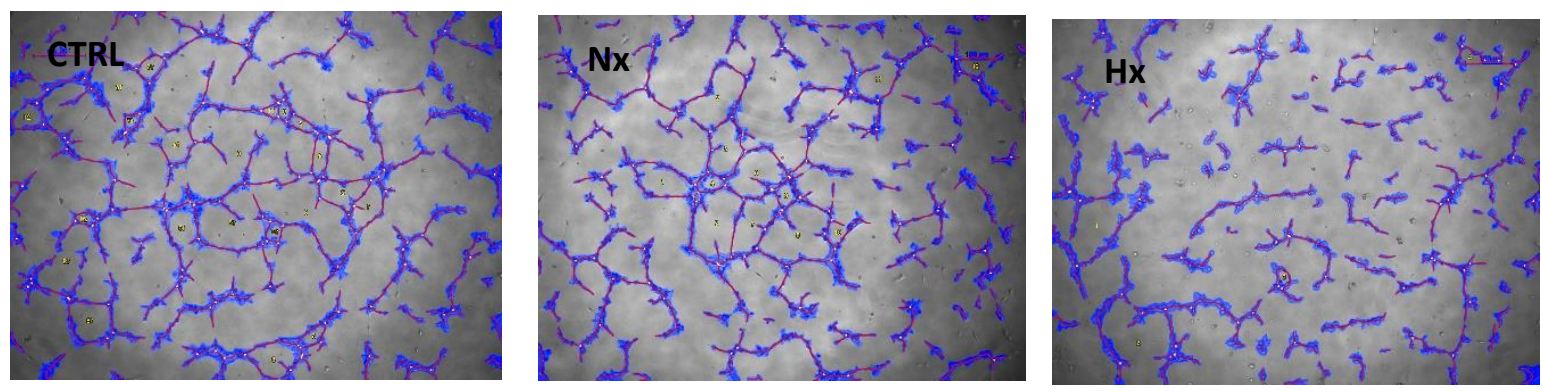

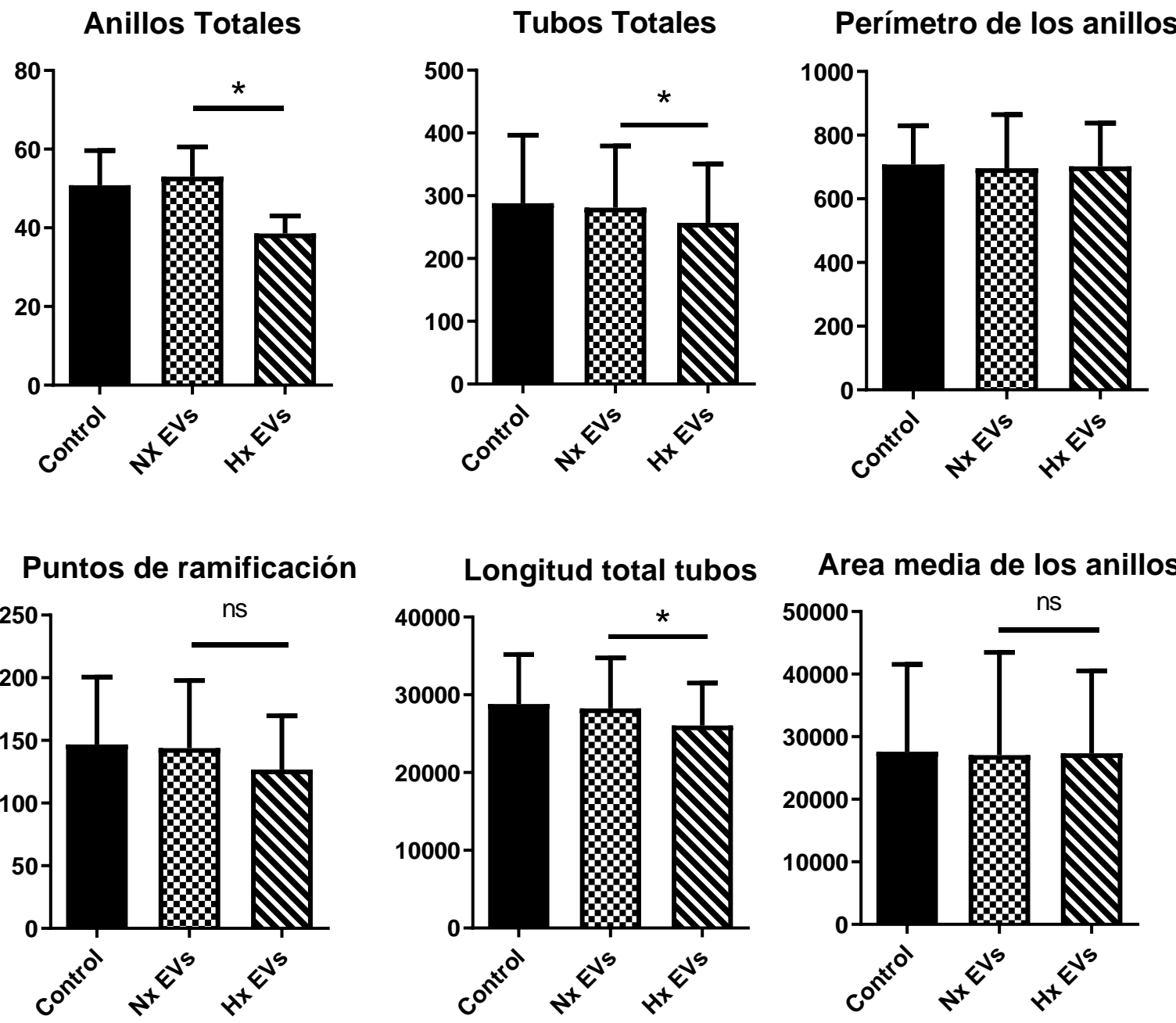

Figura 5: Experimento de angiogénesis in vitro. A) Imágenes representativas de células endoteliales sembradas en Matrigel después de 8 horas tratadas con EVs a una dosis de $15 \mu \mathrm{g} / \mathrm{mL}$ B) Cuantificación de parámetros medidos en los que constan la cantidad de anillos totales, tubos totales, perímetro de los anillos, puntos de ramificación, longitud total de los tubos, y área media de los anillos, $(\mathrm{n}=3 * \mathrm{p}<0.05, \mathrm{~ns}=$ valores estadísticamente no significativos)

\subsection{Las vesículas derivadas de AC10 en estado de hipoxia inducen un aumento de la migración en fibroblastos}

Para evaluar el posible potencial fibrótico de estas vesículas se lleva a cabo un experimento de cerramiento de herida in vitro o "scracht" en el cual los fibroblastos se siembran en alta confluencia y se realiza una marca en el centro del pocillo. Después del tratamiento con las vesículas se evalúa el tiempo que tardan los fibroblastos en 
migrar para cerrar este modelo de herida. Los resultados muestran que las vesículas derivadas de los cardiomiocitos en hipoxia tienen una mayor inducción sobre los fibroblastos a la hora de activar sus mecanismos de migración que las derivadas de normoxia.
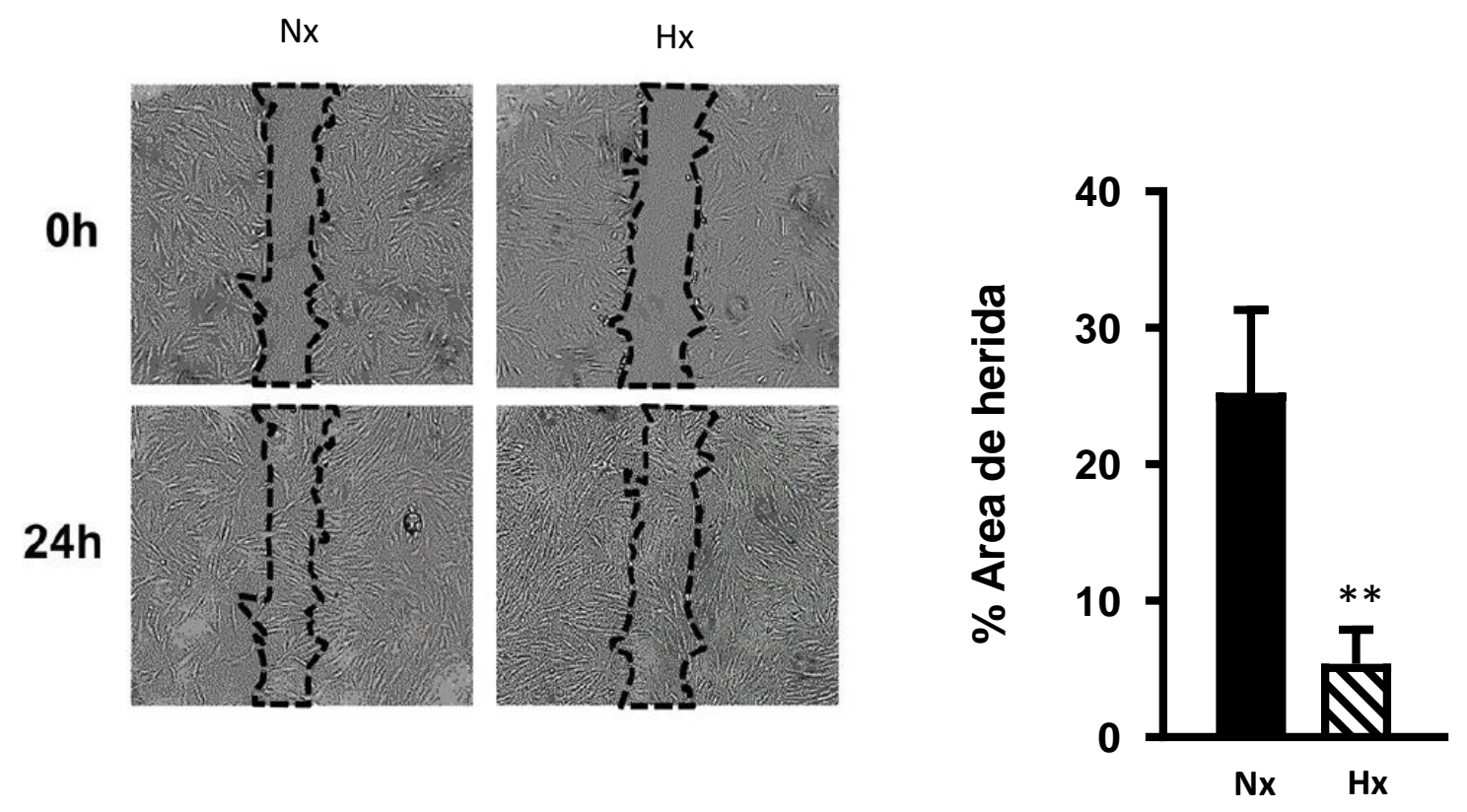

Figura 6: Experimento de migración in vitro. A) Imágenes representativas del cultivo de fibroblastos añadiendo EVs a una concentración de $15 \mu \mathrm{g} / \mathrm{mL}$ en condiciones de $\mathrm{Hx}$ y $\mathrm{Nx}$ a 0 y 24 horas después de realizar el scracht en la placa. B) Cuantificación del área de herida a las 24 horas en ambas condiciones $(\mathrm{N}=6 * * \mathrm{p}<0.01)$

A la luz de estos resultados podemos observar que las células cardiacas ejercen una comunicación activa a través de las vesículas extracelulares y que esta es dependiente del estado en el que se encuentren los cardiomiocitos. Estas vesículas serán captadas de manera diferencial por los diferentes tejidos a los que lleguen. El estado de los cardiomiocitos generará diferencias en la composición proteica de las vesículas que a su vez jugará un papel de importancia en sus efectos como puede ser la migración de fibroblastos o la angiogénesis poniendo de manifiesto la importancia de las vesículas en la comunicación celular como mecanismos de respuesta a un estímulo. 


\section{Estudio prospectivo de miRNAs circulantes pacientes con cáncer de}

$\underline{\text { mama }}$

En el apartado anterior hemos demostrado como los cardiomiocitos son capaces de comunicarse con el resto de tejidos por medio de las vesículas extracelulares en función del estado en el que se encuentran. Esta comunicación activa pone de manifiesto como un perfil de vesículas, así como su contenido, puede ser característico del estado en el que se encuentre el músculo cardiaco. Teniendo esto en cuenta, hemos profundizado en si el estado en el que se encuentre el corazón es capaz de generar un perfil de biomoléculas que se liberen al torrente sanguíneo. Una de esas biomoléculas que pueden jugar un papel de vital importancia son los miRNAs. Estas pequeñas secuencias son RNA no codificante cuya función se centra en una regulación posttranscripcional altamente precisa de la expresión génica. Se plantea la posibilidad de que los miRNAs podrían tener un patrón alterado en aquellos pacientes que tengan una predisposición a sufrir episodios de cardiotoxicidad cuando se tratan con antraciclinas, por lo que a continuación centramos nuestra atención en el estudio de miRNAs circulantes en pacientes con posibles estados de cardiotoxicidad.

\subsection{Caracterización de la cohorte de pacientes}

En total 140 pacientes fueron incluidas en el estudio. De estas, 43 pacientes fueron excluidas por no tener todas las muestras a los puntos del tratamiento indicados en el estudio o por tener datos incompletos. De la cohorte principal de suero se llevaron a cabo análisis en 3 puntos diferentes del tratamiento, Pre- tratamiento con antraciclinas, Post- antraciclinas y un año después del tratamiento con antraciclinas (Rev). Los pacientes que sufren episodios de cardiotoxicidad expresada como un descenso de la FEVI fueron clasificados como casos mientras que el resto se clasificó como controles. La incidencia de carditoxocidad en este tipo de pacientes según las guías se encuentra en torno al $11.4 \%$. En cuanto a la cohorte de plasma fue incluida como cohorte de validación de los datos obtenidos en suero y consta de 32 pacientes. Los datos de ambas cohortes se muestran en las siguientes tablas. 


\begin{tabular}{|c|c|c|c|c|}
\hline & \multicolumn{2}{|c|}{ Cohorte Principal } & \multicolumn{2}{|c|}{ Cohorte de Validación } \\
\hline & $\begin{array}{l}\text { Controles } \\
(n=81)\end{array}$ & Casos $(n=16)$ & $\begin{array}{l}\text { Controles } \\
(n=25)\end{array}$ & Casos $(n=7)$ \\
\hline & $\begin{array}{c}\text { Media } \pm \text { DS } \\
\text { (Rango) }\end{array}$ & $\begin{array}{l}\text { Media } \pm \text { DS } \\
\text { (Rango) }\end{array}$ & $\begin{array}{c}\text { Media } \pm \text { DS } \\
\text { (Rango) }\end{array}$ & $\begin{array}{c}\text { Media } \pm \text { DS } \\
\text { (Rango) }\end{array}$ \\
\hline Edad (años) & $\begin{array}{c}55.3 \pm 12.6(26- \\
79)\end{array}$ & $\begin{array}{c}49.9 \pm 13.2(37- \\
75)\end{array}$ & $\begin{array}{c}53.3 \pm 10.2(33- \\
73)\end{array}$ & $46.3 \pm 5.9(55-42)$ \\
\hline IMC & $\begin{array}{c}26.6 \pm 5.2(17- \\
40)\end{array}$ & $\begin{array}{c}24.1 \pm 4.1(20- \\
35)\end{array}$ & $\begin{array}{l}28.9 \pm 5.4(19- \\
43)\end{array}$ & $30.72 \pm 6.15(21-37)$ \\
\hline \multicolumn{5}{|l|}{ Historial Médico } \\
\hline Hipertensión (\%) & $22(27.2 \%)$ & $1(6.3 \%)$ & $6(24 \%)$ & $1(14.3 \%)$ \\
\hline $\begin{array}{l}\text { Diabetes mellitus } \\
(\%)\end{array}$ & $6(7.4 \%)$ & $2(12.5 \%)$ & $2(8 \%)$ & $0(0 \%)$ \\
\hline Dislipemia (\%) & $31(38 \%)$ & $4(25.0 \%)$ & $3(12 \%)$ & $0(0 \%)$ \\
\hline Fumadores (\%) & $14(17.3 \%)$ & $3(18.8 \%)$ & $7(28 \%)$ & $4(57 \%)$ \\
\hline \multicolumn{5}{|l|}{ Subtipo de cáncer } \\
\hline Triple negativo & $13(16.0 \%)$ & $5(31.3 \%)$ & $1(4.16 \%)$ & $0(0 \%)$ \\
\hline Luminal A & $11(13.6 \%)$ & $1(6.3 \%)$ & $8(33.3 \%)$ & $2(28.6 \%)$ \\
\hline Luminal B & $31(38.3 \%)$ & $2(12.5 \%)$ & $13(54.1 \%)$ & $3(42.8 \%)$ \\
\hline \multicolumn{5}{|l|}{ Dosis Acumulada } \\
\hline TAC $\left(\mathrm{mg} / \mathrm{m}^{2}\right)$ & $269 \pm 49$ & $298 \pm 5$ & $510.20 \pm 135$ & $471.6 \pm 62.18$ \\
\hline $\mathrm{AC}\left(\mathrm{mg} / \mathrm{m}^{2}\right)$ & $237 \pm 52$ & $242 \pm 41$ & $429.58 \pm 180$ & $486 \pm 174.5$ \\
\hline
\end{tabular}

\section{Cohorte Principal Cohorte de Validación}

\begin{tabular}{|c|c|c|c|c|c|c|}
\hline \multirow{3}{*}{$\begin{array}{l}\text { Parámetros } \\
\text { bioquímicos }\end{array}$} & & \multicolumn{3}{|c|}{ Controles $(\mathrm{n}=81)$} & \multirow{2}{*}{\multicolumn{2}{|c|}{$\begin{array}{c}\text { Controles }(\mathrm{n}=25) \quad \text { Casos }(\mathrm{n}=7) \\
\text { Media } \pm \mathrm{DS}\end{array}$}} \\
\hline & & \multicolumn{3}{|c|}{ Media $\pm D S$} & & \\
\hline & & Pre & Post & $\operatorname{Rev}$ & \multicolumn{2}{|c|}{$\begin{array}{ll}\text { Pre } & \text { Post }\end{array}$} \\
\hline \multirow{2}{*}{$\begin{array}{l}\text { Colesterol } \\
(\mathbf{m g} / \mathbf{d l})\end{array}$} & Controles & $216 \pm 34$ & $222 \pm 40$ & $204 \pm 30$ & $214 \pm 26$ & $205 \pm 36$ \\
\hline & Casos & $220 \pm 26$ & $215 \pm 63$ & $200 \pm 48$ & $212 \pm 22$ & $190 \pm 27$ \\
\hline \multirow{2}{*}{$\begin{array}{l}\text { Triglicéridos } \\
(\mathrm{mg} / \mathrm{dl})\end{array}$} & Controles & $103 \pm 49$ & $130 \pm 64^{\dagger}$ & $103 \pm 46$ & $108 \pm 48$ & $131 \pm 79^{\dagger \dagger}$ \\
\hline & Casos & $90 \pm 30$ & $104 \pm 34^{*}$ & $96 \pm 52$ & $96 \pm 62$ & $99 \pm 47$ \\
\hline \multirow{2}{*}{$\begin{array}{l}\text { Glucosa } \\
\text { (mg/dl) }\end{array}$} & Controles & $104 \pm 30$ & $97 \pm 20$ & $98 \pm 25$ & $95 \pm 15$ & $99 \pm 17$ \\
\hline & Casos & $99 \pm 20$ & $115 \pm 33^{\dagger}$ & $100 \pm 28$ & $87 \pm 3$ & $88 \pm 8$ \\
\hline \multirow{2}{*}{$\begin{array}{l}\text { Creatinina } \\
\text { (mg/dl) }\end{array}$} & Controles & $0.64 \pm 0.18$ & $0.64 \pm 0.13$ & $\underset{*}{0.66 \pm 0.11}$ & $0.59 \pm 0.09$ & $0.56 \pm 0.1$ \\
\hline & Casos & $0.67 \pm 0.12$ & $0.56 \pm 0.08$ & $0.61 \pm 0.16$ & $0.60 \pm 0.12$ & $0.6 \pm 0.12$ \\
\hline usTnT & Controles & $4.5 \pm 3.9$ & $13.7 \pm 10.2$ & - & $4.9 \pm 4.6$ & $9.3 \pm 5.8^{*}$ \\
\hline (ng/L) & Casos & $3.5 \pm 0.9$ & $15.1 \pm 6.5^{\ddagger}$ & - & $3.4 \pm 0.68$ & $5.3 \pm 2.2$ \\
\hline
\end{tabular}




\begin{tabular}{llccccc} 
& & Pre & Post & Rev & Pre & Post \\
\hline FEVI (\%) & Controles & $66 \pm 6$ & $64 \pm 5^{\dagger}$ & $63 \pm 4^{\ddagger}$ & $62.0 \pm 5.2$ & $61.3 \pm 5.6$ \\
& Casos & $64 \pm 4$ & $55 \pm 9^{\ddagger \#}$ & $50 \pm 6^{\ddagger}$ & $63.0 \pm 6.9$ & $53.0 \pm 4.0^{\dagger \#}$ \\
& & & & & & \\
VFDVI (ml) & Controles & $84 \pm 22$ & $85 \pm 21$ & $86 \pm 24$ & $92.3 \pm 10.1$ & $89.0 \pm 9.9$ \\
& Casos & $91 \pm 34$ & $96 \pm 30$ & $95 \pm 29$ & $106 \pm 37$ & $108 \pm 28^{\|}$ \\
& & & & & & \\
VFSVI (ml) & Controles & $26 \pm 8$ & $27 \pm 13$ & $26 \pm 8$ & $34.5 \pm 6.7$ & $34.3 \pm 6.8$ \\
& Casos & $27 \pm 11$ & $41 \pm 28^{\|}$ & $39 \pm 17^{\#}$ & $42 \pm 21$ & $52 \pm 18^{\dagger \#}$ \\
& & & & & & \\
GLS (\%) & Controles & $-16.3 \pm 1.9$ & $-15.7 \pm 2.4^{*}$ & $-15.9 \pm 2.4$ & $-22.4 \pm 1.7$ & $-21.7 \pm 1.6$ \\
& Casos & $-17.4 \pm 19$ & $-15.1 \pm 2.3^{*}$ & - & $-21 \pm 1.5$ & $-19 \pm 2.5^{* \S}$ \\
& & & & $12.8 \pm 1.6^{*}$ & &
\end{tabular}

Tabla 1: parámetros clínicos y bioquímicos de los pacientes incluidos en el estudio de miRNAs. Los resultados no muestran diferencias significativas en los parámetros mostrados entre casos y controles salvo en los valores que definen la cardiotoxicidad FEVI y GLS.FEVI: fracción de eyección ventrículo izquierdo. GLS: Strain global longitudinal ventrículo izquierdo IBM: índice de masa corporal; DS:desviación estandar; usTNT: Troponina ultrasensible HER2: human epidermal growth factor receptor 2; TAC: Taxotere(docetaxel), Adriamicina (doxorubicin), and Ciclofosfamida, AC: Adriamicina (doxorubicina) y Ciclofosfamida. ${ }^{*} \mathrm{p}<0.05 ; \uparrow \mathrm{p}<0.001 \ddagger \mathrm{p}<0.001$ después del tratamiento con antraciclinas (Post) versus basal (Pre); $\S \mathrm{p}<0.05$; \| $\mathrm{p}<0.01$; \# $\mathrm{p}<0.001$ en casos vs controles en cada punto temporal.

No se aprecia diferencias significativas entre casos y controles después de la quimioterapia en ningún parámetro analizado, lo cual indica similares características y riesgo de sufrir un episodio de cardiotoxicidad similar. Los niveles de Troponina ultrasensible se encuentran elevados a los pacientes después del tratamiento con antraciclinas los cual se debe a que el suero es tomado justo después de la infusión de antraciclinas lo cual eleva los marcadores de daño cardiaco. En la cohorte de validación la toma de muestra se realiza previa a la infusión de antraciclinas lo cual evita la elevación transitoria de esta Troponina T. Además, se puede observar un aumento en la GLS (Global longitudinal strain) en los pacientes positivos después de la quimioterapia. Los casos en la cohorte principal además sufren una fuerte bajada de la FEVI después de un año del tratamiento después de la cual se les administran fármacos para prevenir el deterioro de la función cardiaca. En el caso de la cohorte de validación los pacientes con indicios de bajada de FEVI fueron tratados inmediatamente después de la detección de síntomas de cardiotoxicidad, lo cual puede explicar la recuperación de FEVI observada después de un año de quimioterapia. 


\subsection{Generación de lista de miRNAs diferencialmente expresados entre casos y controles}

Como se ha mencionado anteriormente las muestras de pacientes tratadas con antraciclinas se someten en comparación a controles a una prueba de miRNAseq para revelar los miRNAs significativamente diferentes entre ellos. Para el análisis del miRNA seq se seleccionan 10 pacientes de los casos que se comparan con 10 del grupo control. Las muestras de suero para las cuales se hace este análisis se toman antes del tratamiento con antraciclinas. En total se analizan 2546 miRNAs de los cuales 212 se detectan y normalizan en función de su abundancia relativa. Este estudio está disponible en la base de datos database BioStudie (http://www.ebi.ac.uk/biostudies) bajo el código de acceso S-HECA437. Para evaluar los miRNAs discriminativos se utilizaron 3 métodos diferentes de análisis de los resultados.

\subsection{Integración de resultados miRNAseq}

Los resultados aportados por cada método se muestran en el siguiente diagrama de Ven. Esta estrategia identifico un total de 37 miRNAs diferencialmente expresados entre casos y controles. Uno de los miRNAs fue identificado por los tres métodos utilizados (hsa-miR-4732-3p). 3 de ellos fueron identificado por Random Forest y el Negative Binomial Test (hsa-miR-150-5p, hsa-miR-215-5p y hsa-192-5p) mientras que uno fue identificado conjuntamente por los test Elastic Net y Random Forest (hsamiR-92b-3p)

\section{Negative Binomial}

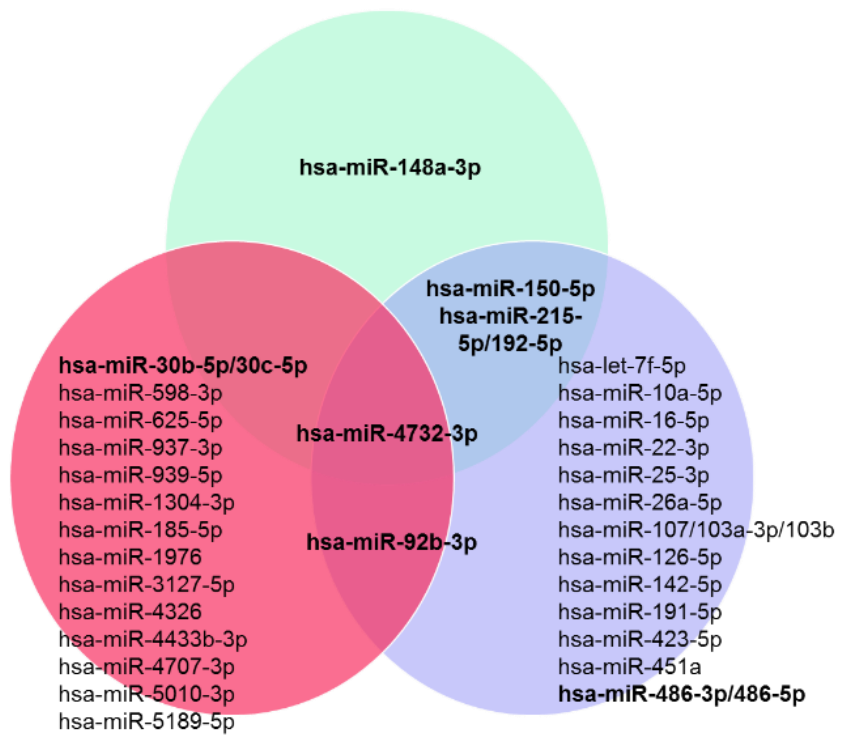

Elastic Net

Random Forest

Figura 7: Diagrama de Venn mostrando los miRNAs diferencialmente expresados entre casos y controles. En este gráfico podemos observar los resultados discriminativos utilizando los algoritmos de Negative Binomial, Elastic Net y Random Forest.(controles $n=10$, casos $n=10$ ) 


\subsection{Evaluación de niveles de miRNA a lo largo del tratamiento quimioterapéutico}

La modulación de los miRNAs es un proceso en constante cambio e incluye una gran cantidad de vías reguladores. Teniendo esto en cuenta y sabiendo que los efectos de la cardiotoxicidad se hacen más evidentes en cuanto más pasa el tiempo es posible que estos miRNA diferencialmente expresados entre casos y controles previo tratamiento con la quimioterapia sea variable a lo largo del tratamiento. Por ello se crean los siguiente Volcano Plots para comparar casos vs control en los diferentes puntos del tratamiento.
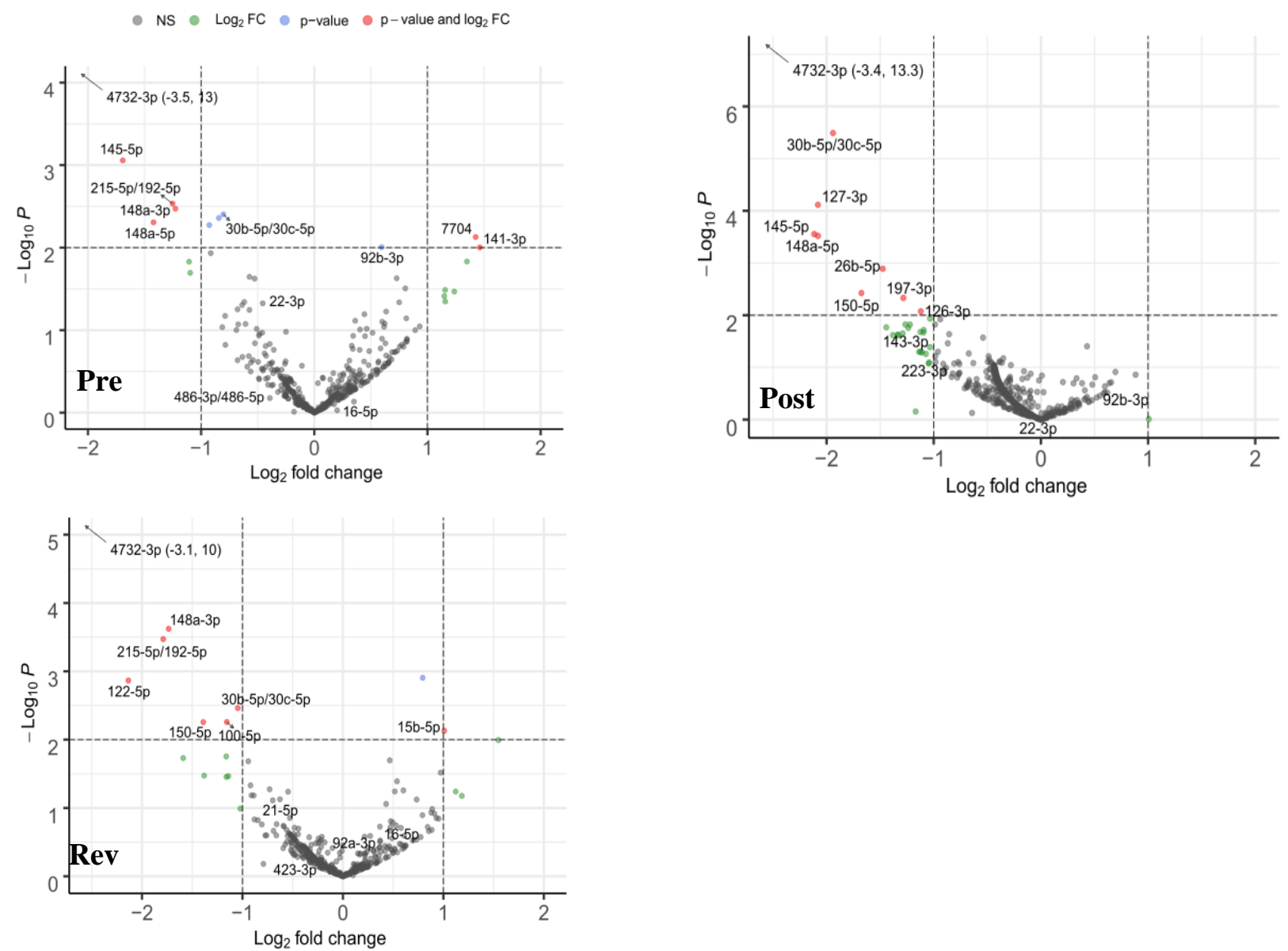

Figura 8: Volcano plots de la expresión diferencial de miRNAs de los pacientes controles frente a los casos. En estos gráficos podemos ver una representación del p valor así como el "fold change" de cada uno de los miRNAs diferenciándose entre casos y controles. En gris se muestran los miRNAs estadísticamente no significativos mientras que en azul se muestran aquellos con un $\mathrm{p}$ valor estadísticamente significativo, en verde se muestran aquellos puntos fuera del rango del fold change entre $\log _{2}-1$ y $\log _{2} 1$. En rojo aquellos estos puntos que cumplen las dos condiciones anteriores. Los gráficos muestran estas diferencias antes del tratamiento (Pre), después del tratamiento (Post) y 1 año después de la finalización del tratamiento (Rev) 
En estos diagramas podemos observar un patrón simétrico de miRNAs en los pacientes previamente al tratamiento con antraciclinas, mientras que en el diagrama posttratamiento vemos una menor abundancia en gran cantidad de miRNAS. Este patrón queda normalizado en el diagrama que representa los miRNAs después de la revisión un año después de la quimioterapia lo cual sugiere una depleción transitoria en los niveles de miRNA después de los tratamientos quimioterapéuticos. Los miRNAs diferencialmente expresados entre casos y controles se encuentran marcados en rojo. Como se puede observar en la figura alguno de estos miRNA como son el hsa-miR92b-3p, hsa-miR-150-5p, hsa-miR-192-5p, hsa-miR-215-5p o el hsa-miR-4732-3p permanecen desregulados después de tratamiento con antraciclinas e incluso durante largos periodos de tiempo.

\subsection{Selección de miRNAs diferencialmente expresados}

Para una mejor comprensión de cómo se modulan los miRNAs en el tiempo del tratamiento de las antraciclinas se comparan la expresión de los miRNAs en diferentes puntos temporales de 37 miRNAs seleccionados anteriormente como discriminativos en el punto Pre. Se eligieron los miRNAs basados en los siguientes criterios

- Detectados por uno o más métodos de regresión

- Se encuentran desregulados en dos o más puntos del tratamiento

- Se encuentran relacionados con procesos de cardiotoxicidad en la bibliografía.

\subsection{Evaluación de los niveles de miRNA seleccionados}

hsa-miR 30b-5p/30c-5p
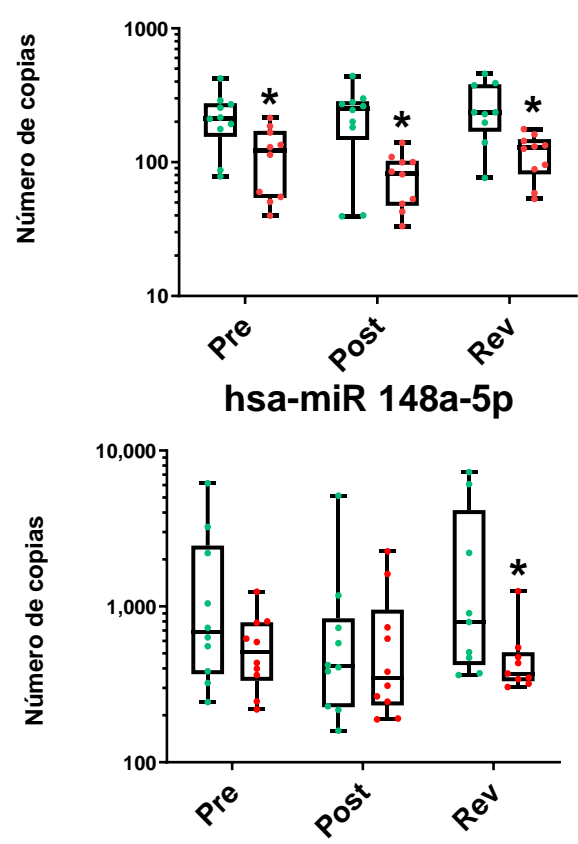

hsa-miR 92b-3p

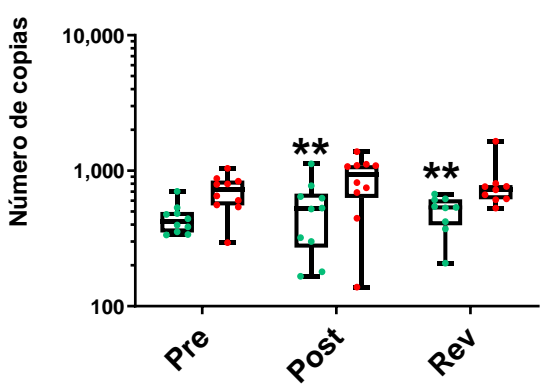

hsa-miR 150-5p

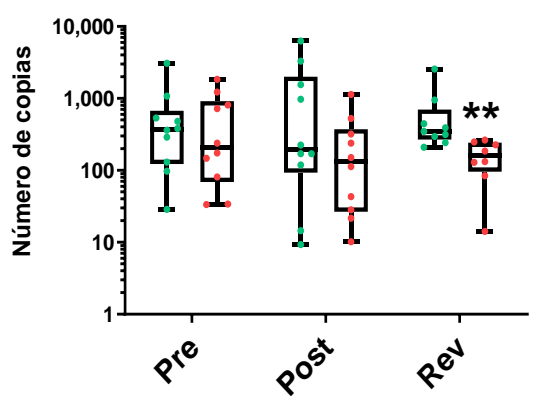


hsa-miR 215-5p/192-5p

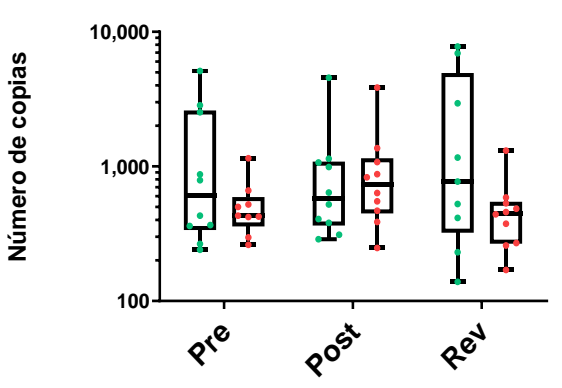

hsa-miR 4732-3p

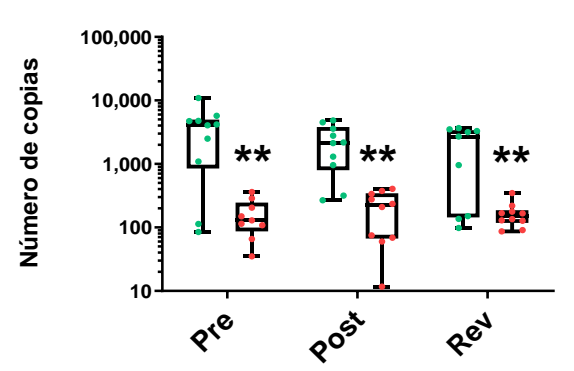

Figura 9: Comparación de los niveles de los miRNAs medidos por conteos en el análisis de miRNAseq diferencialmente expresados entre casos y controles en los diferentes puntos temporales. En cada miRNAs se compararon los niveles de 10 casos frente a 10 controles. $(* p<0.05, * * p<0.01$, Anterior al tratamiento con antracilclinas (Pre), Posterior al tratamiento con antraciclinas (Post), 1 año después del tratamiento con antraciclinas (Rev))

En estas representaciones podemos encontrar que los niveles de algunos miRNAs se encuentran desregulados como indica la bibliografía como por ejemplo el miRNA hsamiR-150-5p o el hsa-miR-21-5p. En el caso de los miRNAs hsa-miR-30b-5p, hsamiR-148a-3p, hsa-miR-215-5p, hsa-miR-150-5p, hsa-miR-223-3p, hsa-miR-215-5p o hsa-miR-4732-3p se aprecian tendencias de los miRNAs a estar infraexpresados en el caso de los casos frente a los controles después del tratamiento con antraciclinas.

\subsection{Validación del RNAseq por qPCR}

La expresión de los paneles de miRNAs fue confirmada por qPCR en la cohorte principal de suero en el punto Pre-tratamiento con un total de 16 casos de cardiotoxicidad y 81 controles. También se añadieron a esta prueba una segunda cohorte de validación utilizando muestras de plasma de otro hospital con un total de 7 casos y 25 controles. 

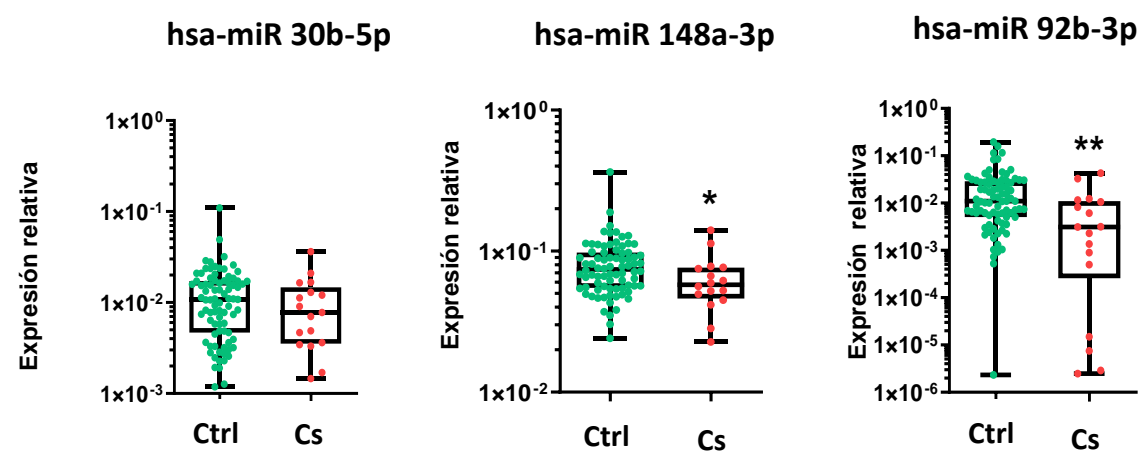

hsa-miR 150-5p
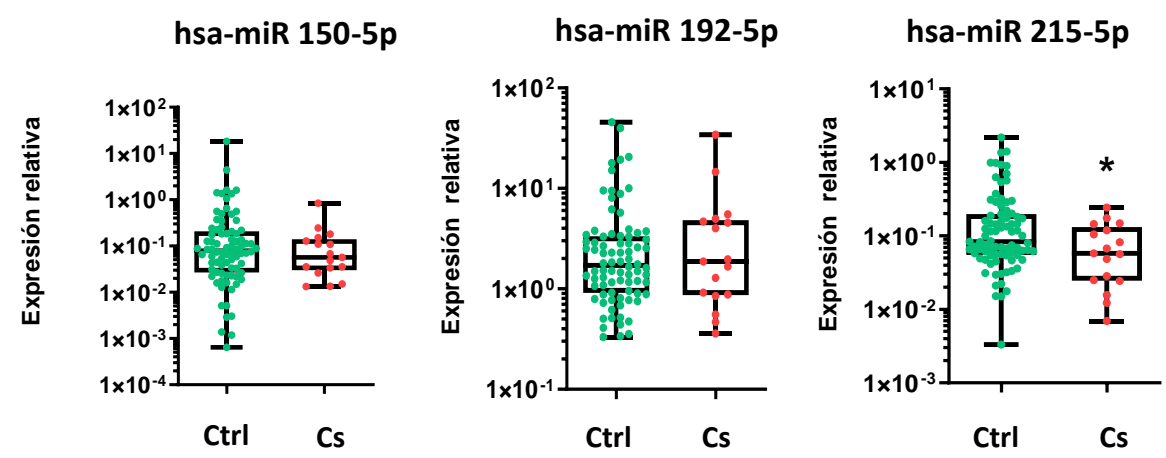

hsa-miR 4732-3p
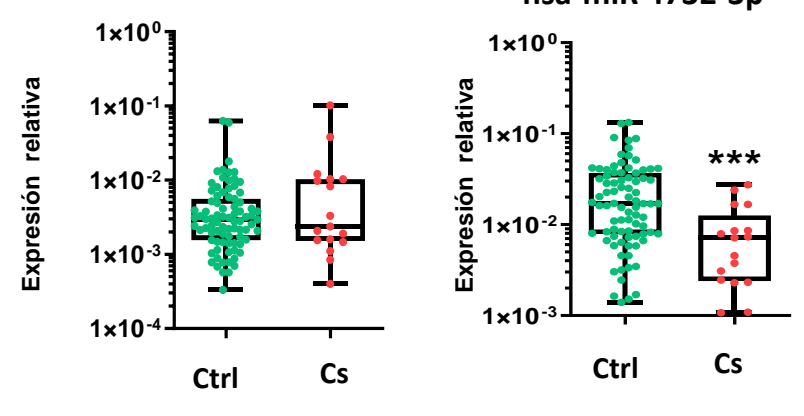

Figura 10: Validación por qPCR de los niveles de los miRNAs diferencialmente expresados entre casos y controles en muestras de suero de la cohorte principal. Para ello se evaluó a un total de 86 controles (Ctrl) frente a 16 casos $(\mathrm{Cs})(* \mathrm{p}<0.05, * * \mathrm{p}<0.01, * * * \mathrm{p}<0.001)$

\subsubsection{Valores en la cohorte de validación}

Una vez se ha cuantificado los niveles de miRNA de la cohorte principal el grupo de investigación pudo conseguir una segunda cohorte para validar estos resultados mediante una colaboración con otro grupo de investigación. 

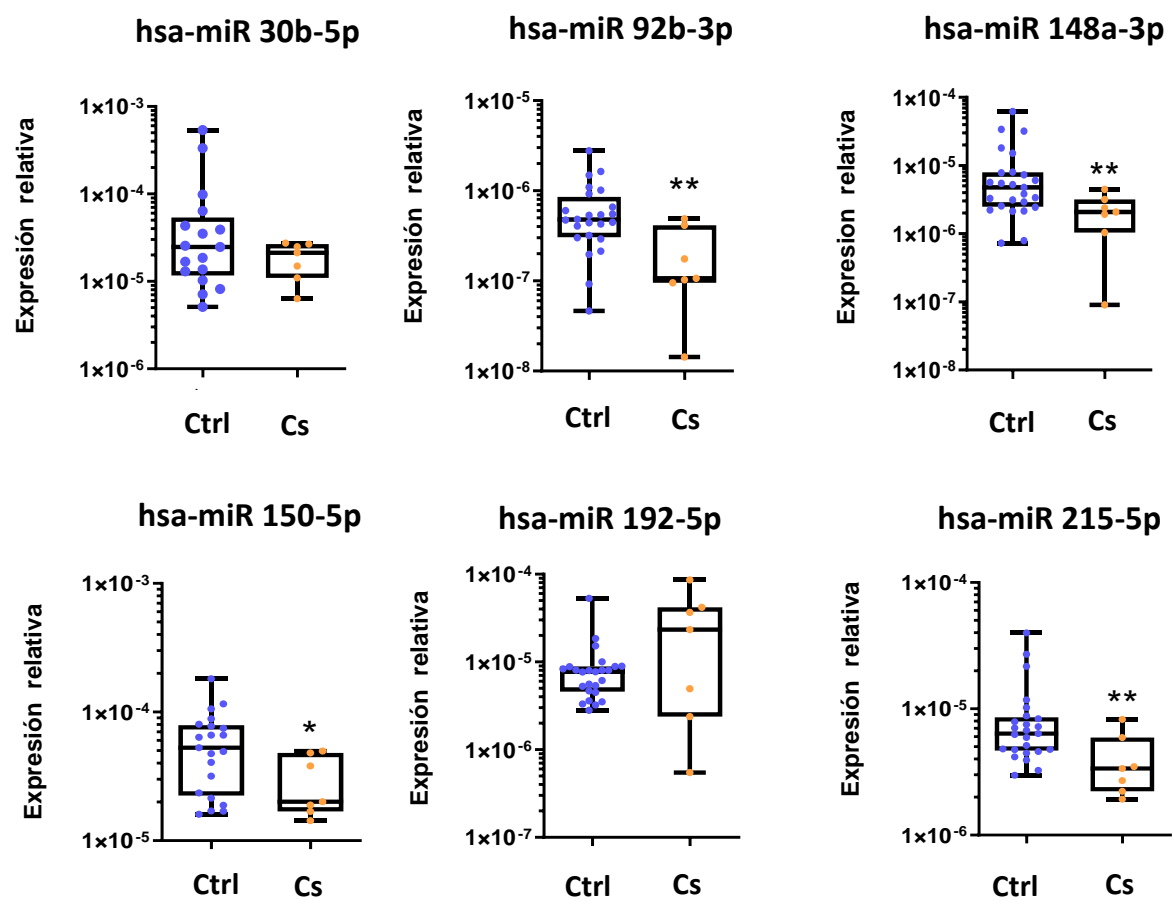

hsa-miR 486-3p

hsa-miR 4732-3p
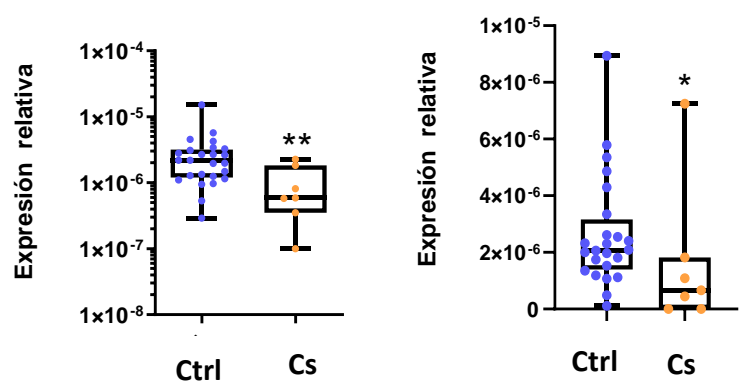

Figura 11: Validación por qPCR de los niveles de los miRNAs diferencialmente expresados entre casos y controles en muestras de suero de la cohorte de validación. Para ello se evaluó a un total de 25 controles $(\mathrm{Ctrl})$ frente a 6 casos $(\mathrm{Cs})(* \mathrm{p}<0.05, * * \mathrm{p}<0.01, * * * \mathrm{p}<0.001)$

mismas tendencias entre los pacientes positivos y negativos. Cabe destacar a su vez, que el bajo número de muestras en la cohorte de plasma debido a la disponibilidad y la poca prevalencia de fenómenos de cardiotoxicidad hacen difícil tanto una comparación de un grupo de controles frente a casos como una comparación de cohortes.

\subsection{Generación de algoritmo de predicción de cardiotoxicidad}

Con el objetivo de crear una firma de predicción de riesgo de cardiotoxicidad previo al tratamiento con antraciclinas, se toman los valores cuantificados por qPCR de los 9 miRNAs que se encuentran desregulados en Pre de la cohorte principal ( $n=97)$. Los 
niveles de los miRNAs, hsa-miR-30b-5p, hsa-miR-148a-3p, hsa-miR-486-3p, hsamiR-192-5p, hsa-miR-92b-3p, hsa-miR-150-5p, hsa-miR-215-5p y hsa-miR-4732-3p se usaron para construir un modelo predictivo de cardiotoxicidad usando un modelo de regresión de efectos mixtos, el cual asigna un coeficiente a cada miRNA con el que se construye el siguiente modelo.

$$
\operatorname{Pr}(\text { Cardiotoxicidad })=\frac{e^{P L}}{1+e^{P L}}
$$

Donde $P L=-7.094-0.166 * \log _{e} m i R-22-3 p+0.561 * \log _{e} m i R-30 b-5 p-0286 * \log _{e} m i R-92-3 p-$ $0.291 * \log _{e} m i R-148 a-3 p+0.112 * \log _{e} m i R-R 150-5 p+0.451 * \log _{e} m i R-192-5 p-0.019 * \log _{e}$ miR-215$3 p+0.649 * \log _{e} m i R-486-3 p-0.269 * \log _{e} m i R-4732-3 p$

Figura 12: Algoritmo de predicción para detectar la cardiotoxicidad basado en los niveles de miRNAs cuantificados por qPCR en la cohorte principal. Los coeficientes de cada miRNA se ajustaron para describir el predictor lineal (PL)

Este modelo alcanzó niveles de predicción de 0.92 AUC. Después de una validación por Bootstrap el AUC se redujo a un valor de 0.79, sin embargo el mejor modelo de predicción se lograba usando solo 7 miRNAs (se excluyó el hsa-miR-22-3p y el hsamiR-215-5p) con lo que el modelo resultante alcanzó valores de AUC de 0.89 antes del Bootstrap y de 0.81 después. El modelo asigno nuevos coeficientes a los miRNAs resultando en la siguiente formula.

$$
\operatorname{Pr}(\text { Cardiotoxicity })=\frac{e^{L P}}{1+e^{L P}}
$$

Where $L P=-4.893+0.13 * \log _{e} m i R-30 b-5 p-0065 * \log _{e} m i R-92-3 p+0.147 * \log _{e}$ $m i R-148 a-3 p+0.038 * \log _{\text {e }}$ miR-R150-5p +0.166*Loge miR-192-5p $+0.318 * \log _{\text {emiR }}-486-3 p-0.0804 * \log _{e} \operatorname{miR}-4732-3 p$

Figura 13: Algoritmo de predicción para detectar la cardiotoxicidad basado en los niveles de miRNAs cuantificados por qPCR en la cohorte de validación. Los coeficientes de cada miRNA se ajustaron para describir el predictor lineal (PL) 


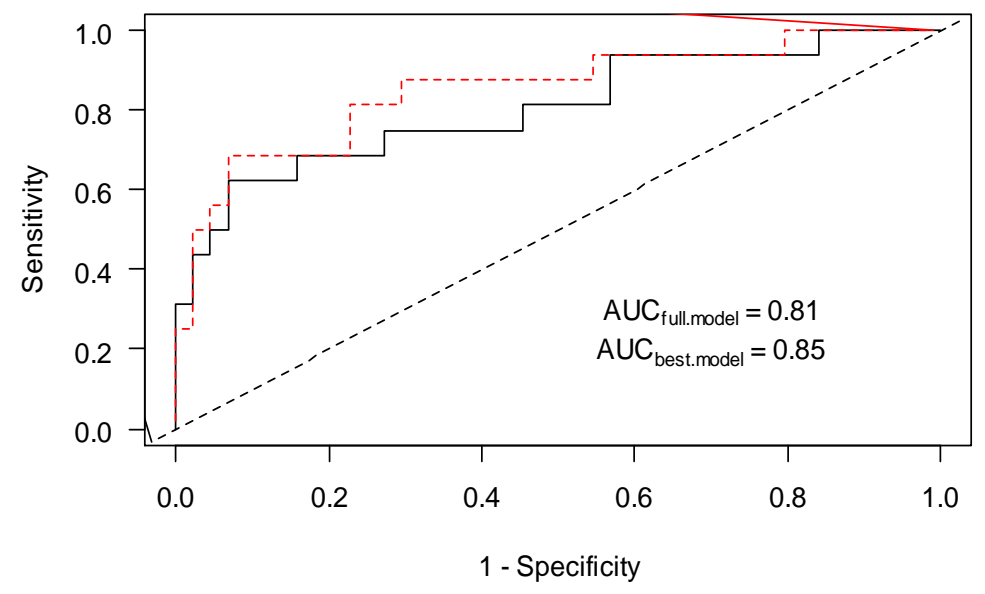

Figura 14: Curva ROC en la que se describe el área bajo la curva en rojo para la cohorte de validación mientras que en negro se puede ver la curva de la cohorte principal. AUC representa el valor de área bajo la curva asociado al valor predictivo del modelo

\subsection{Estudio de las vías de señalización afectadas por el conjunto de miRNAs seleccionados}

Una vez descritos los miRNAs predictores del riesgo cardiaco buscamos la relación de estos miRNAs con las diferentes vías de actuación en las que estuvieran involucradas. Con el objetivo de identificar aquellos procesos biológicos que se encuentran en relación con la combinación de miRNAs que se encuentran diferencialmente expresados entre los casos y los controles se llevó a cabo un estudio del interactoma con los miRNAs seleccionados. El estudio del interactoma combina las interacciones directas e indirectas de los miRNAs con los genes para identificar los procesos biológicos que se encuentran regulados por los miRNAs diferencialmente expresados entre casos y controles antes de recibir la quimioterapia. Los procesos GO significativos se clasificaron por su valor Lor. Los valores Lor positivos indican incrementos en los niveles de esos miRNAs en un proceso biológicos lo cual conlleva una represión de este proceso si lo comparamos con un control, mientras que en el caso de un Lor negativo lo que vemos es un descenso del miRNA y por lo tanto una activación de la vía.

\subsubsection{Enumeración de procesos biológicos diferencialmente expresados}

Los procesos biológicos que afectan estos 37 miRNAs detectados en antes de la quimioterapia se encuentran agrupados en categorías funcionales, de las cuales muchas 
de ellas se encuentran relacionadas con procesos cardiacos, fibrosis, respuesta inmunitaria, apoptosis, metabolismo etc.

\begin{tabular}{|c|c|c|c|c|}
\hline ID & Procesos Biológicos regulados Pre-Tratamiento & Lor & pval & $\mathbf{N}$ \\
\hline GO:0040019 & Regulación positiva del desarrollo embrionario & 1.15 & 0.000 & 8 \\
\hline GO:0030199 & Organización de fibras de colágeno & 0.78 & 0.031 & 8 \\
\hline GO:1902229 & $\begin{array}{l}\text { Regulación de la vía intrínseca de apoptosis en } \\
\text { respuesta a daños en el ADN }\end{array}$ & -0.60 & 0.042 & 11 \\
\hline GO:0002687 & Regulación positiva de migración de leucocitos & -0.45 & 0.042 & 21 \\
\hline GO:0032640 & Producción de Factor de Necrosis Tumoral (TNF) & -0.51 & 0.041 & 18 \\
\hline GO:0006479 & Metilación de proteínas & -0.33 & 0.041 & 39 \\
\hline GO:0001960 & $\begin{array}{l}\text { Regulación negativa de señalización a través de } \\
\text { citoquinas }\end{array}$ & -0.81 & 0.036 & 8 \\
\hline GO:0010906 & Regulación de procesos metabólicos de la glucosa & -0.54 & 0.036 & 14 \\
\hline GO:0050764 & Regulación de la fagocitosis & -0.61 & 0.036 & 14 \\
\hline GO:0032633 & Producción de interleuquina 4 & -0.82 & 0.032 & 7 \\
\hline GO:0006694 & Producción biosintética de esteroides & -0.039 & 0.029 & 31 \\
\hline GO:0043502 & Regulación de adaptación muscular & -0.76 & 0.026 & 9 \\
\hline GO:0051092 & $\begin{array}{l}\text { Regulacion positiva del factor de transcripción NF- } \\
\text { KB }\end{array}$ & -0.47 & 0.025 & 23 \\
\hline GO:0045923 & Regulación positiva del metabolism de ácidos grasos & -0.89 & 0.025 & 7 \\
\hline GO:0006941 & Contracción del músculo estriado & -0.48 & 0.021 & 23 \\
\hline GO:0003612 & Procesos cardiacos & -0.36 & 0.021 & 43 \\
\hline GO:0060047 & Contracción cardiaca & -0.36 & 0.021 & 43 \\
\hline GO:0032612 & Producción de interleuquina 1 & -0.79 & 0.019 & 8 \\
\hline GO:0044346 & Apoptosis de fibroblastos & -0.90 & 0.018 & 8 \\
\hline GO:0086004 & Regulación de la contracción cardiaca & -1.09 & 0.009 & 8 \\
\hline GO:1903115 & $\begin{array}{l}\text { Regulación del movimiento de los filamentos de } \\
\text { actina }\end{array}$ & -1.09 & 0.009 & 8 \\
\hline GO:0032653 & Regulación de la producción de IL10 & -1.04 & 0.005 & 7 \\
\hline GO:0032368 & Regulación del transporte lipídico & -0.65 & 0.004 & 18 \\
\hline GO:0045933 & Regulación positiva de la contracción muscular & -0.97 & 0.004 & 8 \\
\hline GO:0017015 & Regulación de la vía de señalización del TGF- $\beta$ & -0.64 & 0.002 & 25 \\
\hline GO.0090257 & Regulación de procesos sistémicos musculares & -0.6 & 0.002 & 30 \\
\hline GO:0070527 & Agregación plaquetaria & -1.0 & 0.000 & 11 \\
\hline
\end{tabular}

Tabla 2: Tabla en la que se establecen los procesos biológicos involucrados con los miRNAs diferencialmente expresados entre casos y controles GO: Ontología génica ; BP: Proceso biológico,; Lor: logaritmo del ratio; pVal: p valor; N: Número de genes incluidos en la categoría funcional

En esta tabla se puede observar que el pool incrementado miRNAs regula procesos como la organización del colágeno mientras que niveles infraexpresados de miRNAs se relacionan con procesos de remodelación de tejido como puede ser el TGF- $\beta$ o la producción del TNF $\alpha$. También se pueden observar variaciones en procesos relacionados con la hemostasia y la coagulación. El descenso en los niveles de 
miRNAs relacionados con la contracción cardiaca y el desarrollo sugiere que existe una diferencia previa en los pacientes que desarrollaran la cardiotoxicidad en su capacidad para mantener la homeostasis del tejido.

\subsubsection{Red de interacción de miRNAs con procesos biológicos relevantes}

Cabe destacar que de los 8 miRNAs seleccionados para la firma de cardiotoxicidad, la mayoría se encuentran relacionados con estos procesos siendo el miR-4732 presente en 59 de los 62 procesos. Si creamos un interactoma únicamente con estos 8 miRNAs podemos ver un patrón similar de la vías más representativas señaladas previamente.

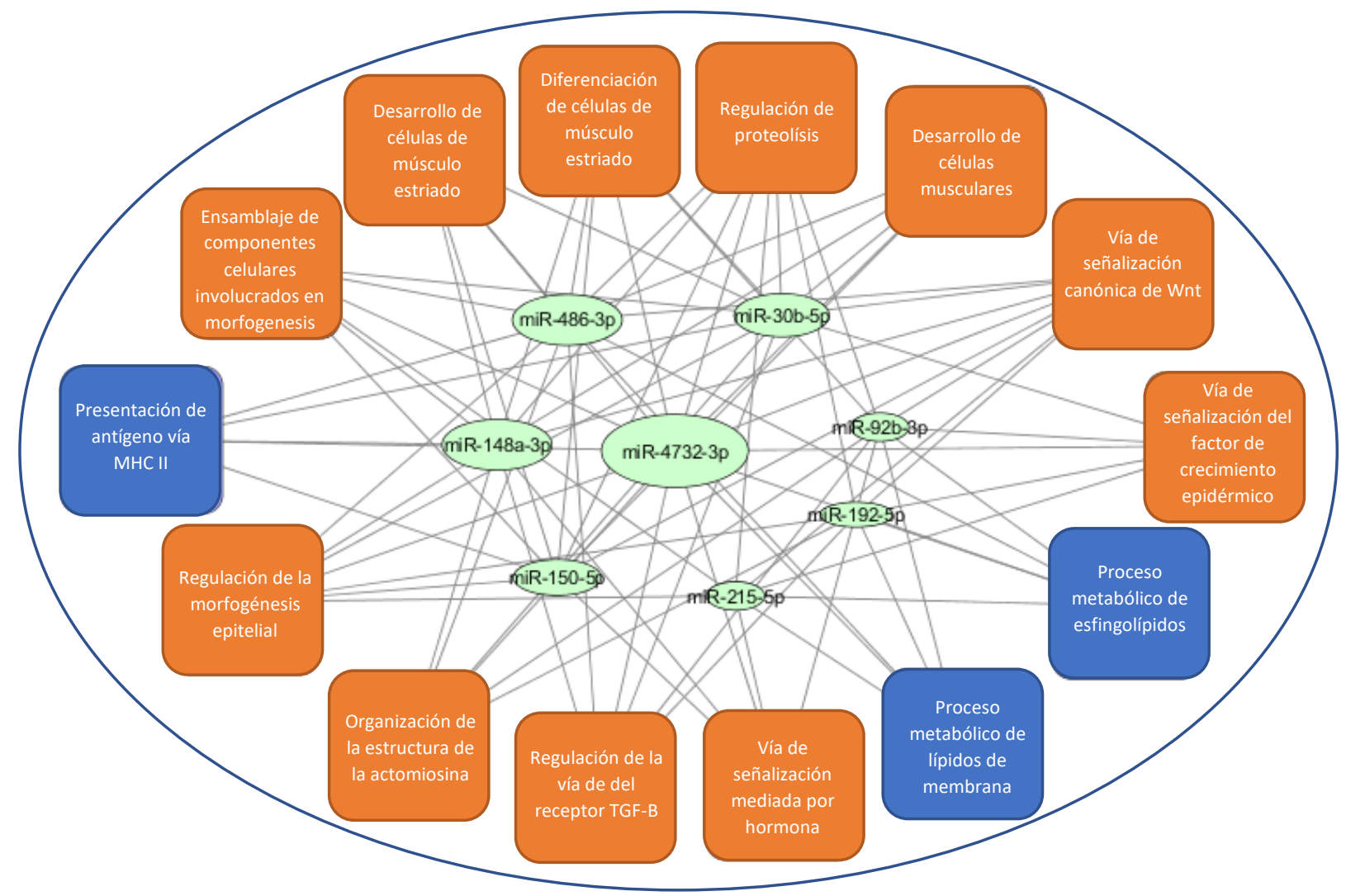

Figura 15: Red de interacción de procesos biológicos relevantes en los que se encuentran involucrados los miRNAs diferencialmente expresados entre casos y controles. El tamaño de los nodos de cada miRNA es proporcional al número de procesos biológicos que afectan.

En esta representación en redes, donde los tamaños de los nodos que contienen los miRNAs son proporcionales al número de procesos biológicos que regulan, se puede ver que la mayor parte de la regulación de los procesos biológicos incluyen el desarrollo del musculo estriado, la vía de Wnt o la estructura de organización de la actomyosina. 
En este diagrama se puede observar en que funciones se engloban los procesos biológicos afectados por estos 8 miRNAs. Como puede observarse en el gráfico la respuesta inflamatoria, procesos cardiacos y metabolismos son las funciones más afectadas por estos miRNAs.

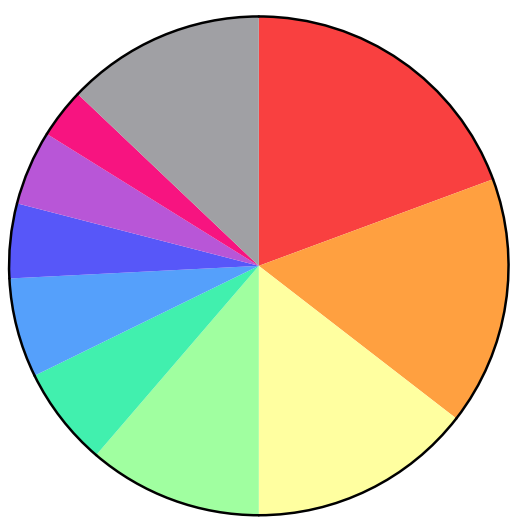

Total $=62 \mathrm{BP}$
Inflammatory Responses

Heart Processes

Metabolism

Neuron Development

RNA Processes

Fibrosis

Apoptosis

Embryonic Development

$\square$ Cell-Cell Adhesion

$\square$ Others

\begin{tabular}{|l|c|}
\hline \multicolumn{1}{|c|}{ miRNA } & BP \\
\hline hsa-miR-4732-3p & 59 \\
hsa-miR-5010-3p & 22 \\
hsa-miR-107 & 20 \\
hsa-miR-939-5p & 20 \\
hsa-miR-5189-5p & 19 \\
hsa-miR-625-5p & 19 \\
hsa-miR-30b-5p & 18 \\
hsa-miR-30c-5p & 18 \\
hsa-miR-142-5p & 17 \\
hsa-miR-25-3p & 17 \\
hsa-miR-126-5p & 16 \\
hsa-mR-148a-3p & 16 \\
hsa-miR-185-5p & 16 \\
hsa-miR-1304-3p & 15 \\
hsa-miR-486-5p & 15 \\
hsa-miR-103a-3p & 14 \\
hsa-miR-3127-5p & 14 \\
hsa-miR-92b-3p & 14 \\
hsa-miR-215-5p & 13 \\
hsa-miR-22-3p & 13 \\
hsa-miR-486-3p & 12 \\
hsa-miR-103b & 11 \\
hsa-miR-16-5p & 11 \\
hsa-miR-192-5p & 11 \\
hsa-miR-4326 & 11 \\
hsa-miR-10a-5p & 9 \\
hsa-miR-150-5p & 9 \\
hsa-let-7f-5p & 7 \\
hsa-miR-26a-5p & 6 \\
hsa-miR-191-5p & 3 \\
hsa-miR-451a & 3 \\
hsa-miR-598-3p & 2 \\
hsa-miR-4707-3p & 1 \\
hsa-miR-937-3p & 1 \\
hsa-miR-1976 & 0 \\
hsa-miR-423-5p & 0 \\
hsa-miR-4433-3p & 0 \\
\hline
\end{tabular}

Figura 16: Diagrama de queso de las funciones afectadas por los diferentes procesos biológicos de los miRNAs diferencialmente expresados 


\section{Potencial terapéutico de las EVs de MSCs en la cardiotoxicidad derivada de antraciclinas}

Una vez hemos descrito como los miRNAs pueden ser potentes predictores de la función cardiaca, nos planteamos diferentes terapias en las que trataremos de revertir el daño por cardiotoxicidad derivado de antraciclinas. Para este cometido nos centramos en la terapia celular con vesículas de MSCs. Como se ha comentado en la introducción las vesículas extracelulares pueden recapitular la mayoría de los efectos terapéuticos de las células de origen sin la necesidad de inyectar células vivas en un paciente. Las EVs han demostrado contener gran variedad de biomoléculas potencialmente terapéuticas como miRNAs proteínas etc. Por este motivo las EVs se plantean no solo como un transportador de sustancias bioactivas sino que, a su vez ejercen un tropismo dirigido así como una captación activa como se ha demostrado en anteriores apartados.

\subsection{Generación de línea de mesenquimales inmortal MSC-TERT}

Con el objetivo de generar una línea permanente de células productoras de vesículas se introdujo en las células mediante un vector lentiviral el gen de la telomerasa TERT, la expresión constitutiva de este gen impide el acortamiento telomérico de las células y por consecuencia que estas no entren en apoptosis. Esta modificación es de vital importancia ya que nos permite estandarizar un tipo de vesícula para nuestro tratamiento de manera que una vez inmortalizada, no hace falta cambiar la biopsia siendo esto muy favorable a la hora de generar lotes de producto terapéutico con resultados reproducibles. La siguiente figura muestra la caracterización de la línea inmortalizada a partir de una biopsia de MSCs derivadas de pulpa dentaria.
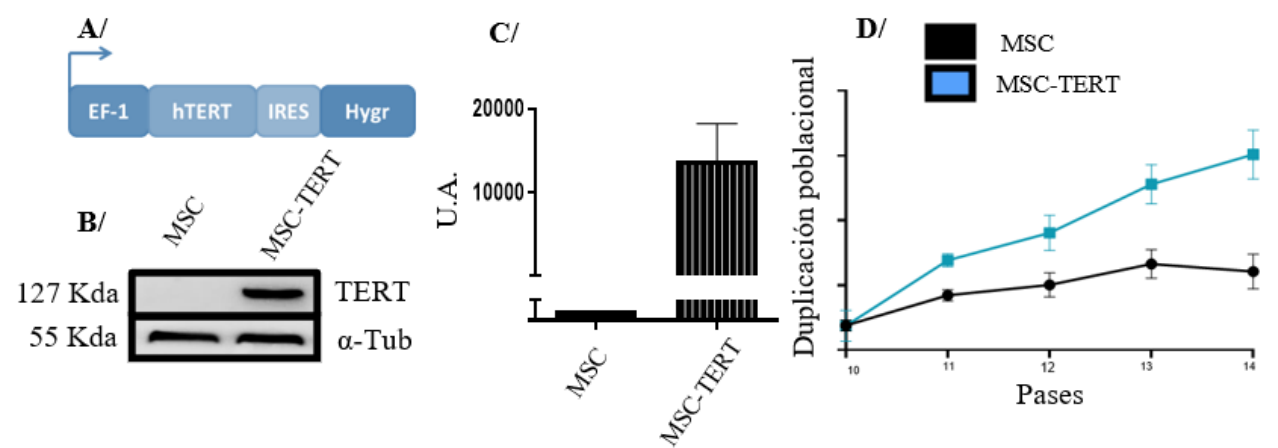

Figura 17: Caracterización de la línea celular MSC-TERT. A) Esquema del plásmido utilizado para la infección lentiviral de las MSCs. B) Expresión de TERT medida por WB. C) Expresión de mRNA de TERT medida por qPCR. D) Experimento de doblado de población la línea azul continúa proliferando mientras que la no infectada entra en senescencia con los pases y deja de multiplicarse 


\subsubsection{Caracterización de las vesículas MSC-TERT}

Como se ha comentado en apartados anteriores, la caracterización de las vesículas extracelulares obtenidas es necesaria para llevar a cabo estudios en ellas. Para este propósito caracterizamos las proteínas características de las vesículas como son CD81, CD9, TSG101, HSP70 o Alix. Una vez caracterizadas observamos su morfología por medio de microscopia electrónica en la que podemos observar tamaños que rondan los 100-150 nm compatibles con el tamaño típico de vesículas extracelulares. A su vez se puede comprobar mediante el estudio de nanotracking que la distribución de tamaños más prevalente se encuentra dentro de este rango.

A)

$110 \mathrm{KDa}$

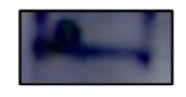

70KDa

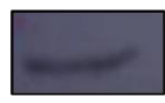

40KDa

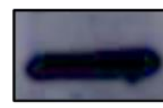

21KDa
ALIX

HSP70

TSG101

CD9
B)

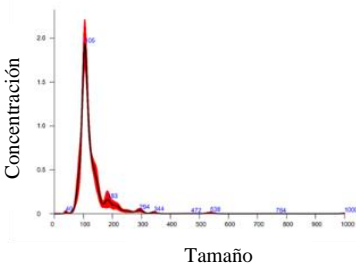

C)

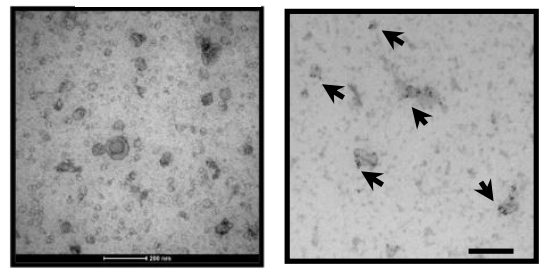

Figura 18: Caracterización de las vesículas extracelulares de MSC-TERT A)Wb de las proteínas usuales para la caracterización de $\operatorname{EVs}(n=3)$. B) Imagen representativa del nanotracking análisis estudiando la distribución poblacional de tamaños en el aislado por ultracentrifugación $(n=3)$. C) Imagen representativa de imagen por microscopia electrónica de las vesículas extracelulares liberadas por las MSC-TERT $(n=3)$ e inmunogold anti-CD63 para detectar la presencia de tetraspaninas en la superficie de las vesículas

\subsection{Las vesículas derivadas de MSC-TERT ejercen efecto terapéutico en el modelo de daño por doxorrubicina.}

A continuación, se evalúa el potencial terapéutico de las EVs derivadas de MSC en el modelo de toxicidad inducida por doxorrubicina. Para ello los cardiomiocitos aislados son tratados con una concentración de $0.1 \mu \mathrm{M}$ de doxorrubicina. A su vez son tratados al principio de la administración de la doxorrubicina con una dosis de $15 \mu \mathrm{g} / \mathrm{mL}$ de EVs seguido de otra más a las 24 horas siguientes. Los experimentos después de estas 48 horas de viabilidad muestran un descenso en el número de células apoptóticas en los cardiomiocitos tratados con vesículas, así como un aumento en la cantidad de células viables. 

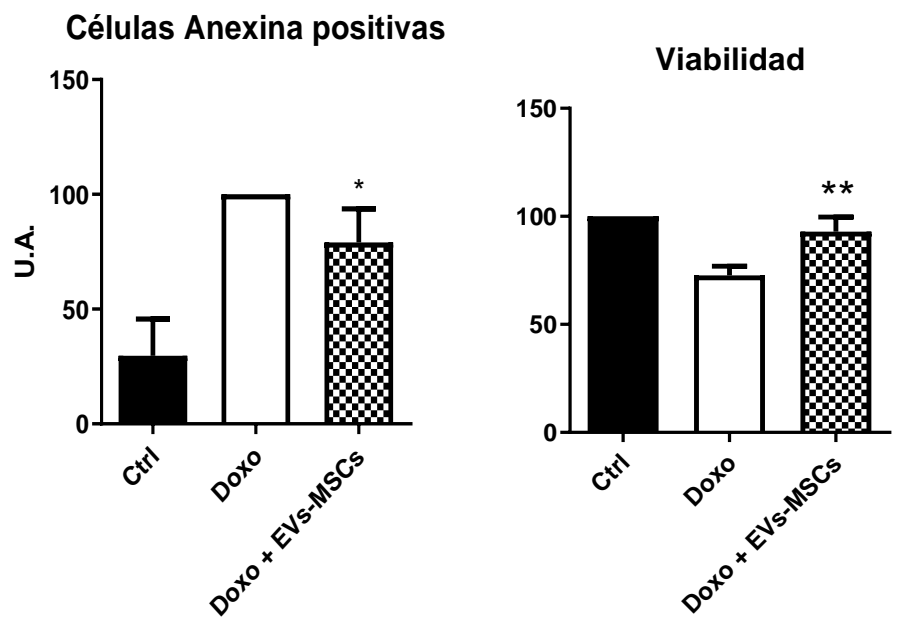

Figura 19: Efecto de las vesículas derivadas de MSC-TERT en el daño por doxorrubicina a 24h $0,1 \mu \mathrm{M}$. A) Cuantificación de células en estado apoptótico medido por citometría de flujo $\left(\mathrm{N}=3^{*} \mathrm{p}<0,05\right)$ B $)$ Viabilidad de cardiomiocitos primarios medido por absorbancia relativa mediante el kit CCK8 $(\mathrm{N}=3 * * \mathrm{p}<0,01)$

A su vez se evaluaron por western blot las principales proteínas que activan vías de apoptosis en las células. Los resultados obtenidos muestran mejoras no significativas en la expresión de proteínas como Clevaged Cas3 y ratio Bax/Bcl2.

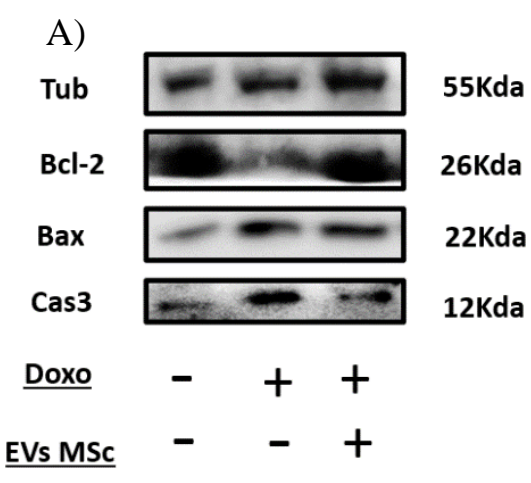

B) Ratio Bcl2/Bax

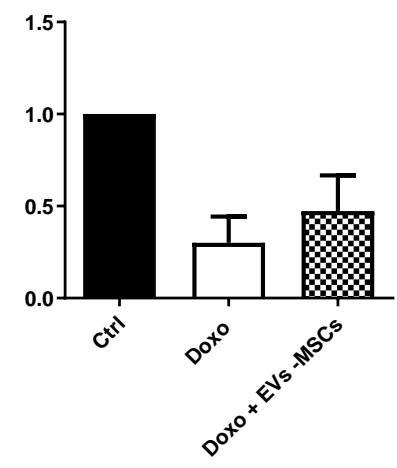

C) Cleavaged cas 3

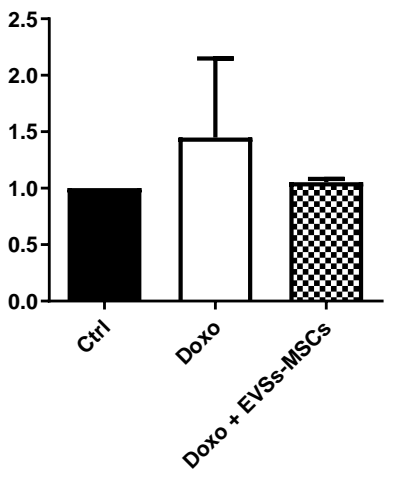

Figura 20: Marcadores proteicos relacionados con la apoptosis en cardiomiocitos tratados a una dosis de $0,1 \mu \mathrm{M}$ de doxorrubicina durante $24 \mathrm{~h}$. A) Imagen representativa de las bandas de wb obtenidas $(\mathrm{n}=3)$ B) Ratio de las proteínas Bcl-2/Bax normalizado a células sin tratamiento( $\mathrm{N}=3$ ) C) Cuantificación relativa de la proteína Cas3 procesada normalizada a niveles de proteína sin tratar con doxorrubicina. $(\mathrm{N}=3)$. 


\subsection{Las vesículas derivadas de MSCs-TERT reducen los niveles de ROS en cardiomiocitos tratados con doxorrubicina}

En el apartado anterior se comprueba que el aumento de supervivencia generado en los cardiomiocitos no se debe a una supresión de proteínas pro-apoptóticas por lo que a continuación se comprueba la capacidad de las EVs derivadas de las MSCs para reducir la producción de ROS. La generación de una cantidad excesiva de ROS en las células después de un tratamiento con doxorrubicina es uno de los principales mecanismos de daño de este medicamento.

A)

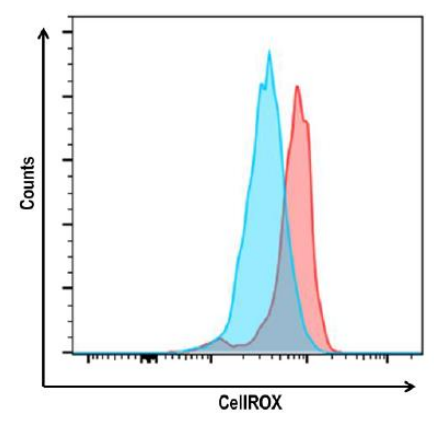

B)

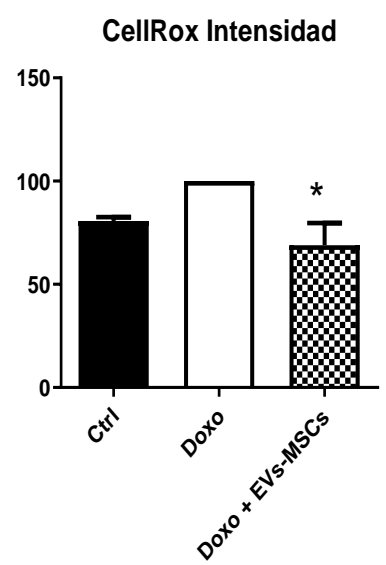

Figura 21: Determinación de la producción de ROS en cardiomiocitos después de ser tratados con una dosis de doxorrubicina de $0,1 \mu \mathrm{M}$ durante 24 horas mediante el kit CellRox ${ }^{\circledR}$ medido por citometría de flujo en un FACS Canto II. A) Gráfica representativa del aumento en la fluorescencia del reactivo CellRox en el caso de las células con doxorrubicina (Rojo) frente a las tratadas con EVs (Azules) B) Cuantificación de la intensidad geométrica de fluorescencia del reactivo CellRox $\left(\mathrm{N}=3,{ }^{*} \mathrm{p}<0,05\right)$

Los resultados demuestran que una administración de EVs en cardiomiocitos durante el tratamiento con doxorrubicina reduce de manera significativa los niveles de ROS producidos por este fármaco. La cantidad de ROS se midió mediante el reactivo CellRox ${ }^{\circledR}$ en un Facs Canto II

\subsection{La adicción de EVs-MSC sobre un cultivo de cardiomiocitos reduce la cantidad de doxorrubicina captada por ellos}

Debido a la estructura molecular de la doxorrubicina, esta posee la capacidad de ser fluorescente cuando se es excitada a una longitud de onda de $488 \mathrm{~nm}$. Esto nos permite, usando la técnica de citometría de flujo, calcular la concentración de doxorrubicina relativa que se encuentre en los cardiomiocitos. Para determinar la cantidad se realizó 
un experimento donde se evalúa la intensidad de fluorescencia en cardiomiocitos tratados con concentraciones crecientes de doxorrubicina. Los resultados muestran una buena linealidad en el crecimiento de la intensidad lo que permite, usando modelos de regresión lineal calcular la cantidad de doxorrubicina en estos cardiomiocitos en el rango estudiado.

A)

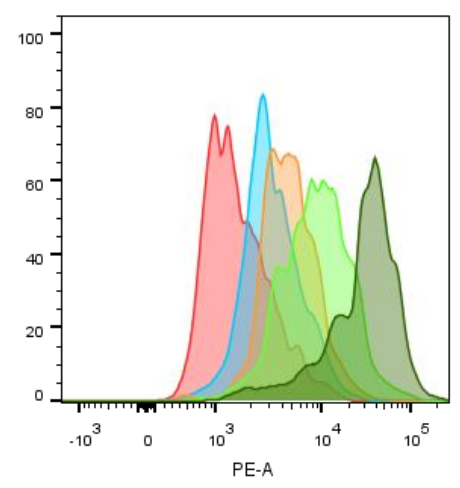

B)

\section{Curva de Concentración de Doxorrubicina}

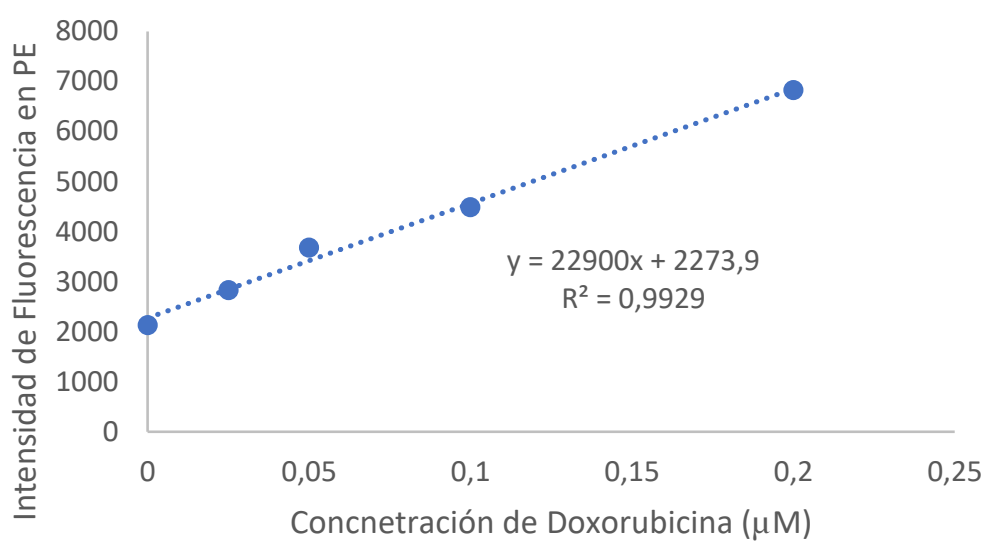

Figura 22: Determinación de fluorescencia en cardiomiocitos tratados con una concentración creciente de doxorrubicina FACS Canto II. A) Diagrama representativo del aumento en la fluorescencia en cardiomiocitos a las concentraciones $0,2 \mu \mathrm{M}$ (Verde oscuro), $0,1 \mu \mathrm{M}$ (Verde claro), $0,05 \mu \mathrm{M}$ (Naranja), $0,025 \mu \mathrm{M}$ (Azul) y $0 \mu \mathrm{M}$ (Rojo) B) Curva de regresión relacionando la intensidad geométrica de fluorescencia de la doxorrubicina con su concentración.

Utilizando estos métodos de regresión lineal se calculó a partir de la intensidad de fluorescencia a 598nm la cantidad de doxorrubicina en los cardiomiocitos. Como puede observarse en la figura 23 los niveles de doxorrubicina en los cardiomiocitos se reduce en un $60.5 \%$ en promedio. Esto equivaldría a la reducción de la dosis en los cardiomiocitos de un $0.1 \mu \mathrm{M}$ a $39.5 \mathrm{nM}$

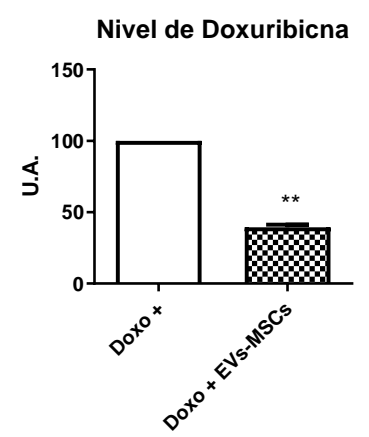

Figura 23: Determinación de la concentración de doxorrubicina presente en cardiomiocitos tratados con EVs a una concentración de $15 \mu \mathrm{g} / \mathrm{mL}$ tras un tratamiento de $0,1 \mu \mathrm{M}$ durante 24 horas. La medición de fluorescencia se llevó a cabo en un FACS Canto II tras lo cual se determinó la concentración usando la gráfica de la figura $22(\mathrm{n}=3, * * \mathrm{p}<0,01)$. 


\subsection{El tratamiento con EVs no reduce la cantidad de doxorrubicina captada por células tumorales}

Como se ha demostrado en el experimento anterior, las vesículas derivadas de MSCTERT reducen la cantidad de doxorrubicina por lo que se plantea la posibilidad de que las vesículas se encuentren encapsulando esta doxorrubicina y por lo tanto puedan interferir en el tratamiento anticancerígeno. Por ello se repite el experimento anterior usando en lugar de cardiomiocitos dos líneas celulares de cáncer de mama MDA-MB231 (línea celular metastásica de cáncer de mama) y MCF-7 (línea de cáncer de mama menos agresiva). En ambos casos queda demostrado que el tratamiento con vesículas no induce cambios en la cantidad de doxorrubicina que son capaces de captar, incluso se puede observar que en el caso de la línea cancerígena más agresiva las vesículas inducen un efecto contrario, es decir, aumentan de manera significativa la cantidad de doxorrubicina que las células cancerígenas captan.

MCF7

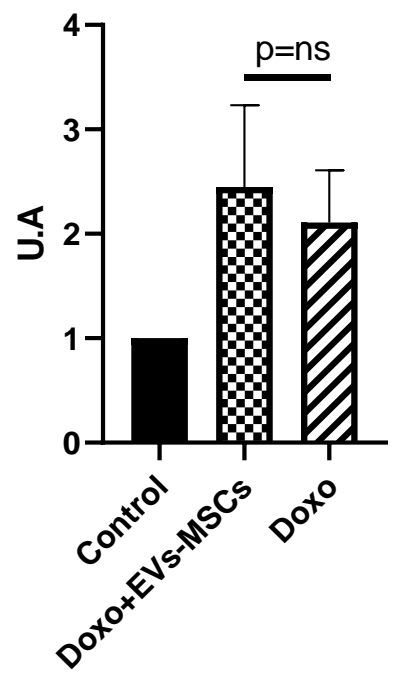

MDA-MB-231

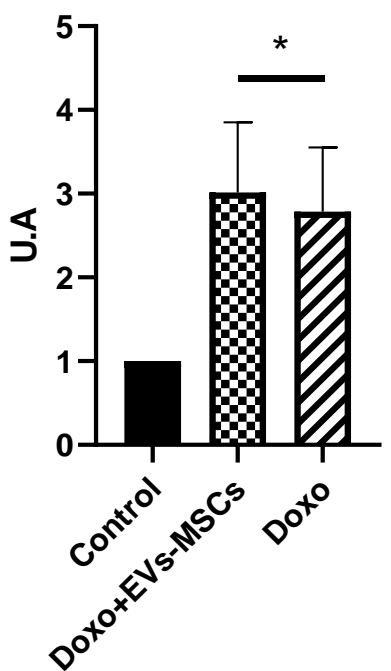

Figura 24: Determinación de la concentración de doxorrubicina presente en 2 líneas celulares de cáncer de mama tratados con EVs a una concentración de $15 \mu \mathrm{g} / \mathrm{mL}$ tras un tratamiento de $0,1 \mathrm{uM}$ durante 24horas. La medición de fluorescencia se llevó a cabo en un FACS Canto II tras lo cual se determinó la concentración usando la gráfica de la figura $22(n=3, * p<0,05)$. 


\subsection{Las EVs derivadas de MSC-TERT mejoran la angiogénesis en células endoteliales tratadas con doxorubicina}

A continuación, se evalúa el papel de las EVs en los modelos de angiogénesis in vitro. Para ello se trataron las células endoteliales HUVEC con doxorrubicina y se evaluó mediante el programa Wimasis la capacidad de formación de estructuras tubulares en estas células. Los resultados muestran una mejora en las células endoteliales tratadas con vesículas extracelulares en comparación con aquellas tratadas únicamente con la doxorrubicina.

A)
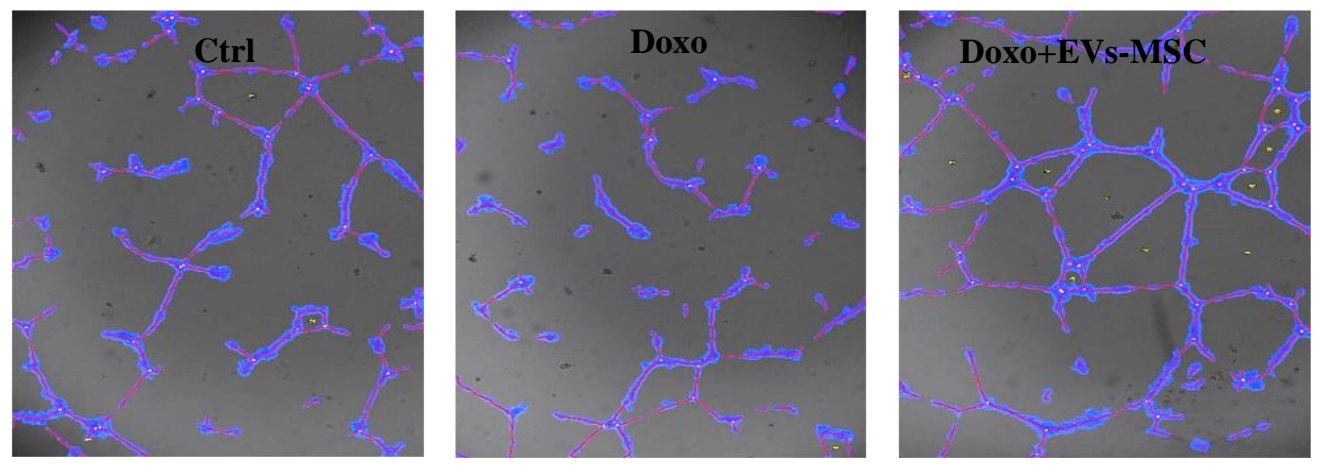

B) Longitud total de tubos
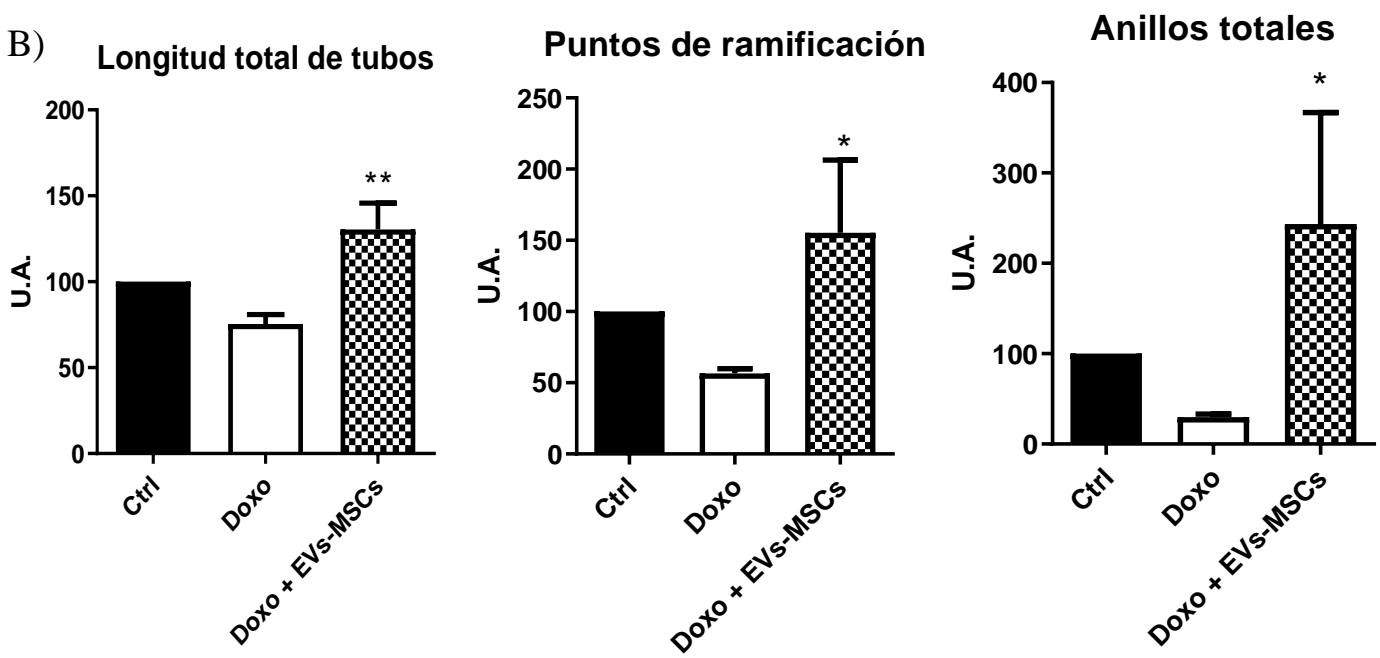

Figura 25: Determinación de la capacidad angiogénica de las MSC-EVs a una dosis de $15 \mu \mathrm{g} / \mathrm{mL}$ en células endoteliales tratadas con doxorrubicina durante 24 horas a una concentración de $0,1 \mu$ M.A) Imágenes representativas de las estructuras tubulares formadas en el Matrigel@.B) Cuantificación de los diferentes parámetros angiogénicos por medio del software online Wimasis. $(\mathrm{n}=3, * \mathrm{p}<0,05, * * \mathrm{p}<0,01)$. 


\subsection{Las vesículas de MSC-TERT no afectan a la supervivencia de los fibroblastos en el daño mediado por doxorrubicina}

Con el objetivo de determinar el papel de las vesículas extracelulares en los procesos fibróticos que aparecen en el músculo cardiaco después del tratamiento con antraciclinas se comprobó la viabilidad, así como la generación de ROS en fibroblastos después de ser tratados con doxorrubicina. Como se muestra en los resultados el tratamiento con EVs no aumenta el número de fibroblastos viables sin embargo si reduce de manera significativa la cantidad de ROS producida por los mismos.

Viabilidad

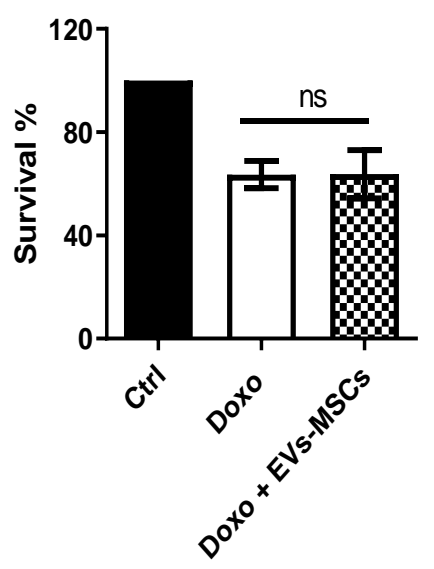

CellRox

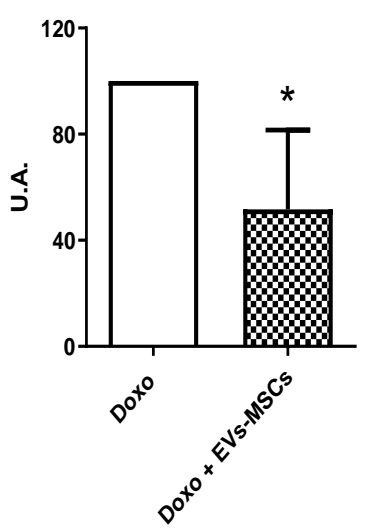

Figura 27: Determinación del efecto de las MSC-EVs a una dosis de $15 \mu \mathrm{g} / \mathrm{mL}$ en la viabilidad y producción de ROS en fibroblastos tratados con doxorrubicina durante 24 horas a una concentración de $0,1 \mu \mathrm{M}$. $(\mathrm{n}=3, * \mathrm{p}<0,05)$.

\subsection{El tratamiento de fibroblastos con EVs reduce la capacidad de migración de los fibroblastos}

La capacidad de migración de los fibroblastos se correlaciona con una potencial fibrosis que puede generarse después de un daño en los cardiomiocitos. El hecho de que los fibroblastos aumenten su capacidad migratoria implica una ocupación del espacio de los cardiomiocitos que han muerto en procesos de cardiotoxicidad siendo reemplazado por estos fibroblastos y su matriz extracelular sin capacidad contráctil. Nuestros resultados demuestran que las EVs añadidas en el modelo in vitro de cicatrización de heridas reducen la capacidad migratoria de los fibroblastos. Este resultado junto con el resultado anterior de viabilidad pone de manifiesto que el efecto de las vesículas no se debe a una inhibición de la proliferación celular. 


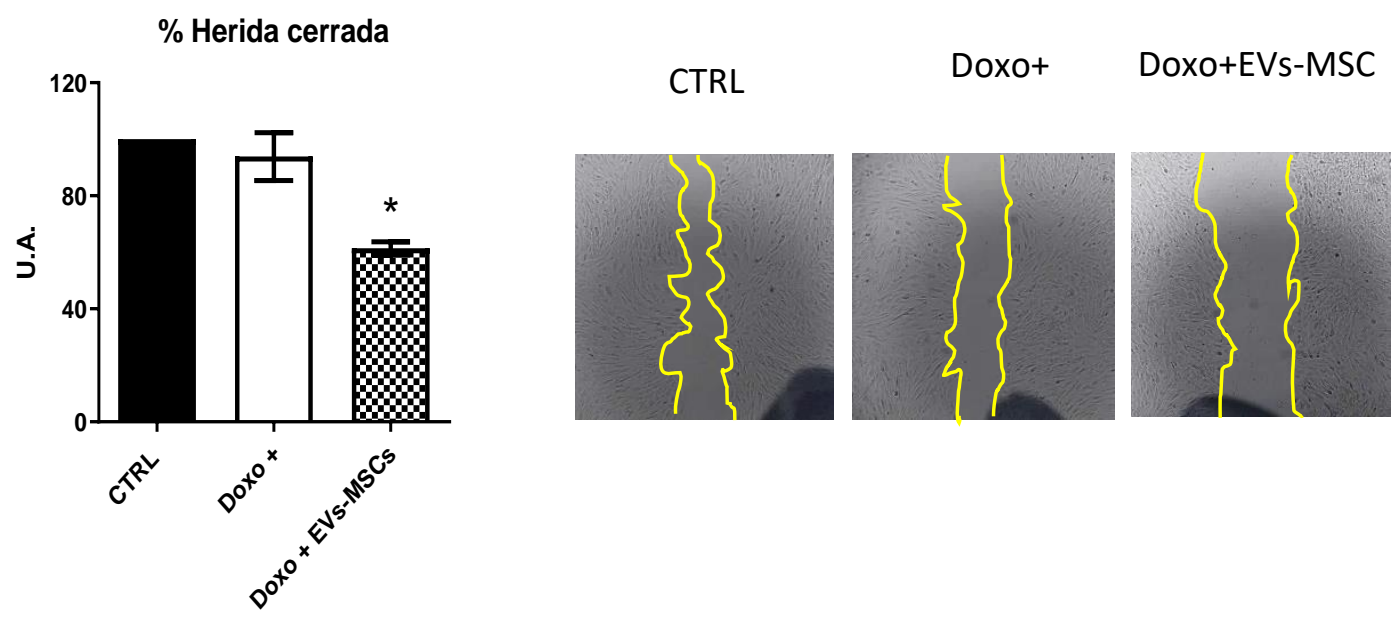

Figura 28: Determinación del efecto de las MSC-EVs a una dosis de $15 \mu \mathrm{g} / \mathrm{mL}$ en la capacidad de migración de fibroblastos tratados con doxorrubicina durante 24 horas a una concentración de $0,1 \mu \mathrm{M}$. Las imágenes se tomaron a las 24 horas de realizar el scracht y se normalizaron con el área que presentaban al inicio de proceso $(n=3, * p<0,05)$.

\subsection{Las EVs derivadas de las MSC-TERT reducen marcadores de inducción a miofibroblastos, así como la generación de matriz extracelular}

Cuando se produce un proceso de cardiotoxicidad uno de los fenómenos más importantes es la fibrosis acompañada a este suceso, esta fibrosis genera una ocupación del espacio que queda libre por los cardiomiocitos que han muerto durante el proceso de cardiotoxicidad por los fibroblastos. Esto genera por otra parte, una serie de señales que inducen una diferenciación del fibroblasto a miofibroblasto, este último tiene una mayor capacidad proliferativa y una mayor capacidad de generación de matriz extracelular para conseguir evitar la lesión de manera rápida, sin embargo, una proliferación excesiva de miofibroblastos puede dar lugar a una gran área sin capacidad contráctil poniendo en peligro la funcionalidad cardiaca. En el siguiente experimento se testó la capacidad de las EVs para reducir la diferenciación de los fibroblastos a miofibroblasto (mayor capacidad proliferativa y generación de matriz extracelular). Para ello se evaluó por qPCR una serie de genes relacionados con la producción de matriz extracelular y la diferenciación a miofibroblasto. Nuestros resultados muestran que un tratamiento con doxorrubicina induce la diferenciación a miofibroblasto mientras que el tratamiento de estas células con vesículas extracelulares reduce tanto la expresión de algunos de estos marcadores como la expresión de proteínas relacionadas con la matriz extracelular. 

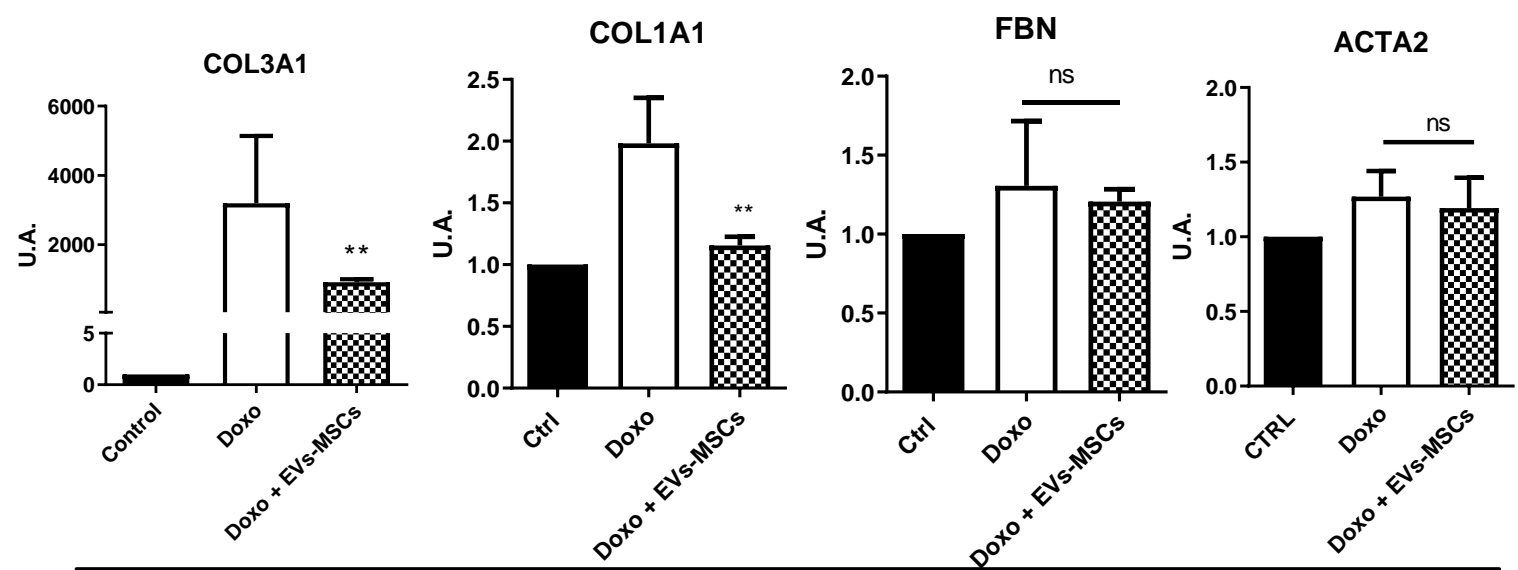

Figura 29: Determinación del efecto de las MSC-EVs a una dosis de $15 \mu \mathrm{g} / \mathrm{mL}$ en la expresión profibróticos en fibroblastos tratados con doxorrubicina durante 24 horas a una concentración de 0,1 $\mu \mathrm{M}$. Los niveles de los genes Colágeno 3 (COL3A1) Colágeno 1 (COL1A1), Fibronectina (FBN), y Actamiosina (ACTA2) fueron medidos por qPCR en un Viia7 $(n=3, * \mathrm{p}<0,05)$.

\subsection{Modelos animales supervivencia con vesículas}

Finalmente se quiso comprobar en un modelo in vivo de cardiotoxicidad el potencial terapuetico de las EVs. Para este objetivo tomamos 2 grupos de ratones a los cuales se les induce una cardiotoxicidad mediante inyección de manera intraperitoneal doxorrubicina a una dosis de $15 \mathrm{mg} / \mathrm{kg}$ y doxorrubicina con EVs. Los resultados indican una mayor supervivencia en aquellos ratones que recibieron la doxorrubicina junto con las EVs lo cual demuestra su potencial terapéutico.

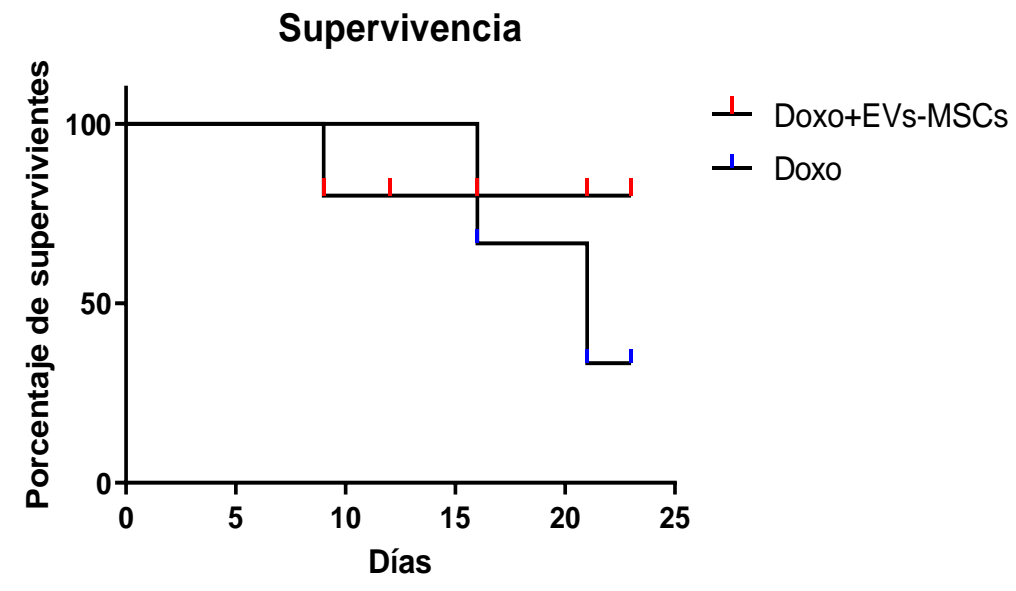

Figura 30: Determinación del efecto de las MSC-EVs a una dosis de $30 \mu \mathrm{g}$ por ratón en la supervivencia en ratones inyectados con doxorrubicina intraperitoneal a una dosis de $15 \mathrm{mg} / \mathrm{kg}$. La curva muestra una mayor supervivencia en los ratones tratados con EVs (rojo) frente a los que llevan únicamente la dosis aguda de doxorrubicina (Azul). No se muestra la curva de PBS ya que esta contenía una supervivencia del $100 \%(\mathrm{~N}=5$ por grupo de animales $)$ 


\subsubsection{La inyección conjunta de EVs y doxorrubicina protege frente a la bajada de peso de los ratones}

Uno de los efectos más evidentes de la toxicidad de la doxorrubicina más evidente es la pérdida de peso general en los animales inyectados con este fármaco. Para este experimento se monitorizó el peso de los ratones durante las semanas posteriores a la inyección de doxorrubicina y vesículas de manera intraperitoneal. Los resultados muestran que los ratones inyectados con vesículas tienden a perder menos peso que aquellos tratados únicamente con la doxorrubicina.

perdida de peso $(\mathrm{g})$

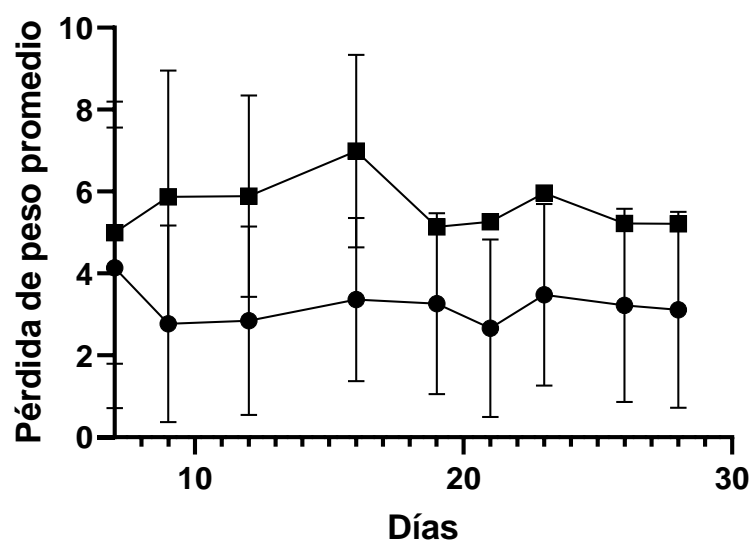

- Doxo+EVs-MSCs

$\rightarrow$ Doxo

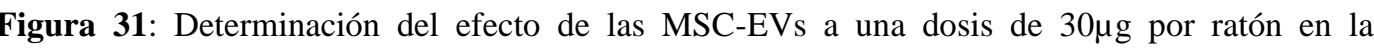
supervivencia en ratones inyectados con doxorrubicina intraperitoneal a una dosis de $15 \mathrm{mg} / \mathrm{kg}$.La curva muestra la pérdida de peso que se produjo en promedio de los animales que continuaban vivos en el experimento. No se muestra la curva de PBS ya que no se produjeron efectos en el peso $(\mathrm{N}=5$ por grupo de animales)

\subsubsection{La inyección de doxorrubicina a dosis aguda no ejerce un efecto fibrótico en}

el corazón

Para evaluar la presencia de fibrosis cardiaca estudiamos el corazón de los ratones una vez pasa 1 mes de tratamiento con la doxorrubicina. Una vez sacrificados los ratones del experimento anterior se procedió a la fijación del corazón mediante perfusión de PFA. Una vez fijados los corazones se procedió a su inclusión en bloque y a su cortado. Para evaluar si la doxorrubicina había provocado procesos de fibrosis cardiaca se llevó a cabo una tinción Sirius Red en el cual el colágeno fibrótico se tiñe de un color rojo intenso. De esta manera comparando los niveles de esta tinción, se puede evaluar la fibrosis cardiaca comparando a los animales tratados con EVs frente los tratados con doxorrubicina y PBS. Desafortunadamente la tinción no reveló diferencias entre los niveles de colágeno presente entre el grupo de PBS, EVs o Doxorrubicina, lo cual 
sugiere que la dosis aguda de doxorrubicina ejerce un efecto tóxico a corto plazo sin llegar a producir la cronificación que da lugar a los procesos de fibrosis.

A)

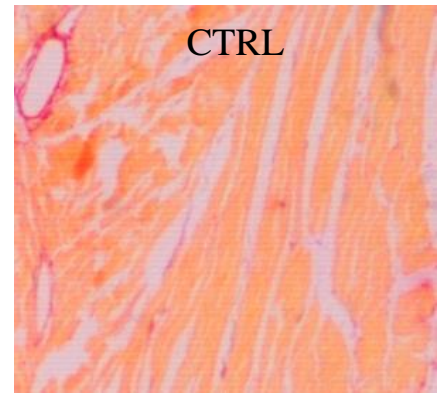

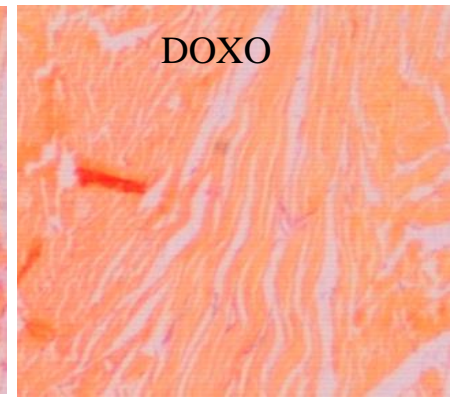

B)

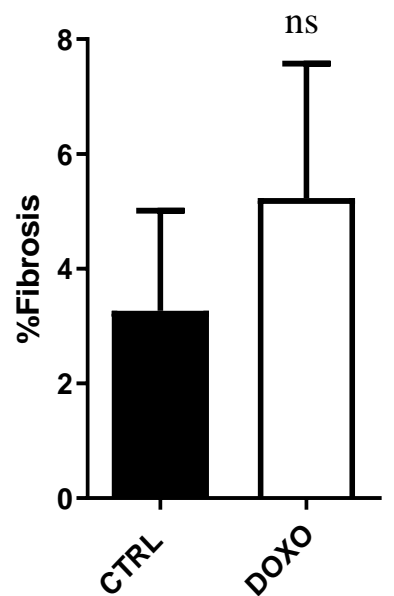

Figura 32: Determinación del porcentaje de fibrosis en animales tratados con doxorrubicina a una concentración de $15 \mathrm{mg} / \mathrm{kg}$ de manera intraperitoneal. Los corazones fueron fijados, incluidos en parafina y cortados. Sobre las rodajas se aplicó la tinción de rojo Sirio la cual se cuantifico mediante el sofware ImageJ A) Imágenes representativas de la tinción en cada grupo B) Cuantificación de la fibrosis en cada grupo de animales ( $\mathrm{N}=3$ por grupo de animales)

\section{Estudio del contenido de miRNA en las vesículas de MSC}

\subsection{Comparación de niveles de miRNA en vesículas MSC frente a MSC- TERT.}

Una vez se ha determinado el potencial terapéutico de las vesículas derivadas de MSCTERT nos centramos en la búsqueda de la molécula o moléculas responsables del efecto terapéutico. Como se ha visto en los apartados anteriores los miRNAs pueden jugar un papel importante en la regulación y función de gran cantidad de procesos celulares, por lo que se decide investigar el contenido y función de estas moléculas presentes en las EVs.

Una de las primeras dudas que se planteaban es si la inmortalización de las células mesenquimales generaba un cambio en el perfil de miRNAs presentes en las vesículas de estas. Para averiguar este punto se llevó a cabo un miRNAseq de las vesículas MSCTERT comparadas con las no infectadas. Los resultados esquematizados en la Fig 33 muestran que de los 2656 miRNA encontrados en las vesículas 2633 son comunes entre ambas. (99.17\%) mientras que solo 22 son encontrados únicamente en MSC- 
TERT pero no en las MSC normales mientras que un solo miRNA se encuentra en las MSC pero no en las MSC-TERT

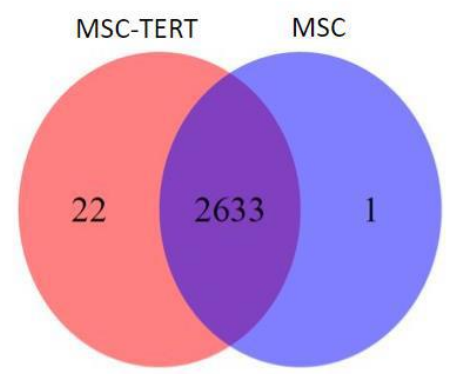

Figura 33: Diagrama de Venn mostrando los miRNAs compartidos entre las MSC-TERT y las MSC sin modificar. Los miRNAs se detectaron por miRNAseq a partir de 4 muestras independientes.

\subsection{Presencia de miRNAs involucrados en la función cardiaca en las vesículas extracelulares}

Como hemos visto en el primer apartado de esta tesis los miRNAs juegan un papel de vital importancia en procesos biológicos involucrados en la homeostasis cardiaca. Por ello se estudiaron el contenido de las vesículas extracelulares para buscar la firma de miRNAs que predisponían a sufrir riesgo de sufrir cardiotoxicidad. En la Fig 34 se demuestra que estos miRNAs se encuentran en cantidades detectables dentro de las vesículas extracelulares. La presencia de estos miRNAs pone de manifiesto que las vesículas son capaces de transferir miRNAs que influyen en la homeostasis cardiaca

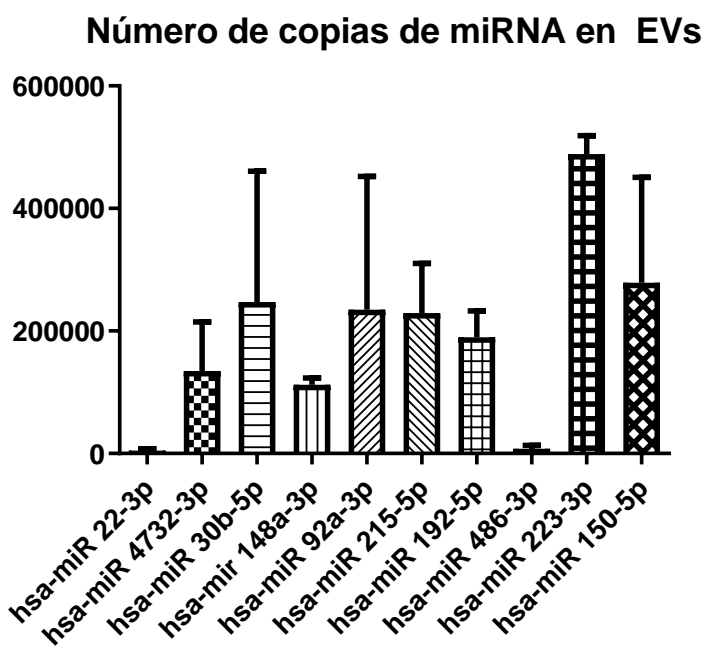

Figura 34: Cantidad de miRNAs presentes en $50 \mu \mathrm{g}$ de EVs derivadas de MSC-TERT. Los resultados se obtuvieron mediante cuantificación por qPCR en el que los resultados de Cts se compararon con una curva patrón de cada miRNA para determinar el número de copias en cada uno de ellos. $(\mathrm{N}=3)$ 
$\underline{\text { 5. Relación entre los niveles de miRNA y la patología cardiaca }}$

\subsection{Los niveles de miRNAs involucrados en la cardiotoxicidad varían sus niveles en células cardiacas después de un tratamiento con doxorrubicina}

Para comprobar si estos miRNAs se encontraban modulados una vez generados un daño por cardiotoxicidad se extrajo y cuantificó los miRNAs de la firma de cardiotoxicidad en cardiomiocitos después de tratarlos con doxorrubicina a una concentración de $0,1 \mu \mathrm{M}$ durante 48 horas. Tras este proceso se extrajo el miRNA y se cuantificó por medio de qPCR normalizando los valores obtenidos al miRNA hsa-miR 16-5p Los resultados muestran un claro descenso en los niveles de estos miRNAs en la mayor parte de los miRNAs salvo en los casos del hsa miR-192, y 215 en los que no se aprecia una subida significativa y en el caso del hsa-miR-486-3p en el que se puede ver que los niveles aumentan después del tratamiento con doxorrubicina.

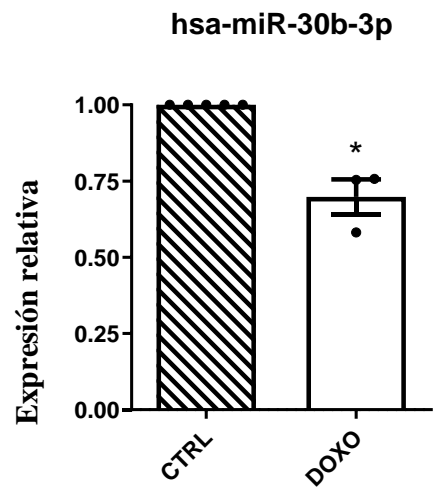

hsa-miR-150

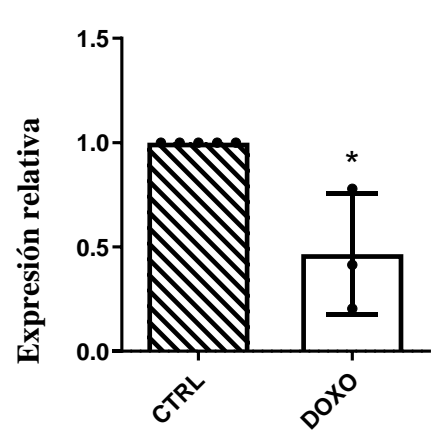

hsa-miR-92-3p

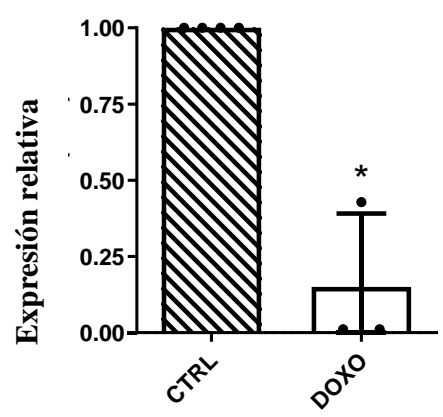

hsa-miR-192

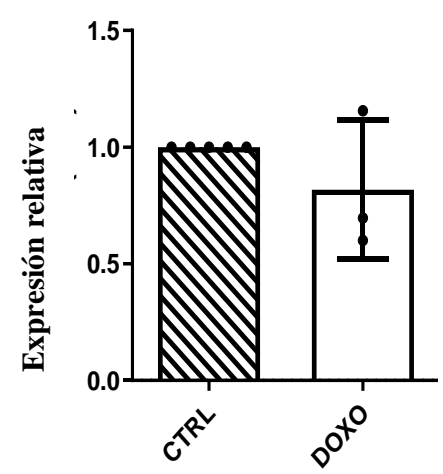

hsa-miR-148a

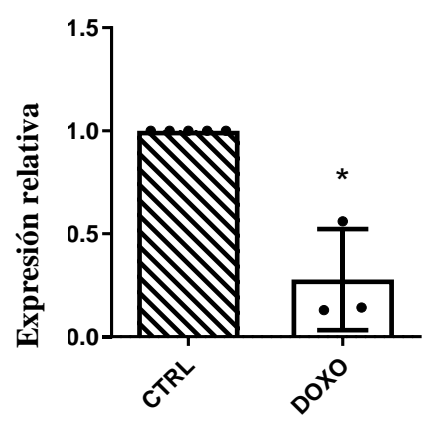

hsa-miR-215

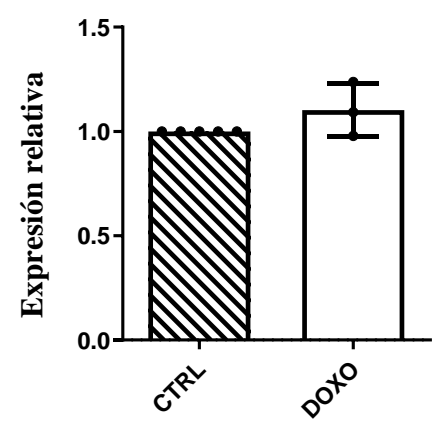



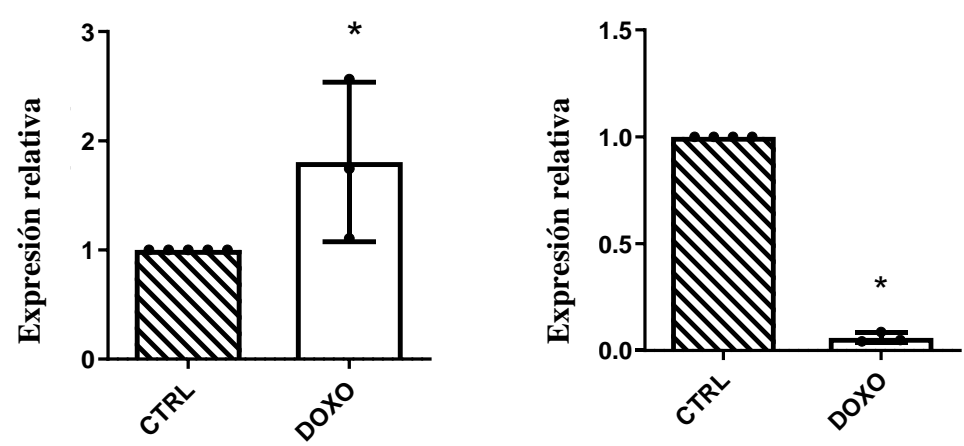

Figura 35: Cantidad de miRNAs presentes en cardiomiocitos después de un tratamiento con doxourubicna durante 48 horas a una concentración de $0,1 \mu \mathrm{M}$. Los resultados se obtuvieron mediante cuantificación por qPCR normalizada a los valores del miRNA hsa-miR-16-5p. (N=3, $* \mathrm{p}<0,05)$

\subsection{El aumento de los niveles de estos miRNAs vía transfección ejerce un efecto protector sobre los cardiomiocitos en el daño por doxorrubicina}

Una vez determinado que la cardiotoxicidad por doxorrubicina disminuye en gran medida los niveles de la mayoría de estos miRNAs, se estudió el efecto de aumentar de manera artificial la cantidad de miRNA presente en los cardiomiocitos con el objeto de comprobar su capacidad terapéutica sobre el daño por doxorrubicina. Los resultados muestran que la transfección de los miRNAs 148a, 150, 486 y 4732 a una concentración de $20 \mathrm{nM}$ generan un efecto protector en los cardiomiocitos comparados con un control negativo de transfección. Cabe destacar el papel del miRNA 4732 ya que es el miRNA que más diferencialmente expresado se encontraba en los pacientes positivos vs los negativos, y como vemos en esta figura su transfección aumenta en mayor medida que el resto de miRNAs su viabilidad.
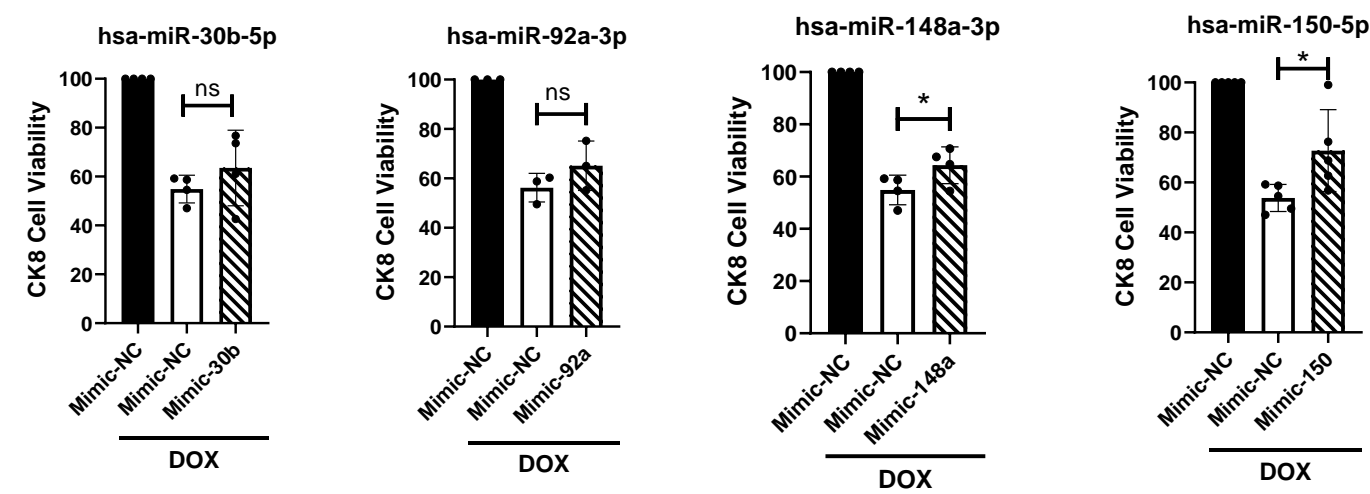

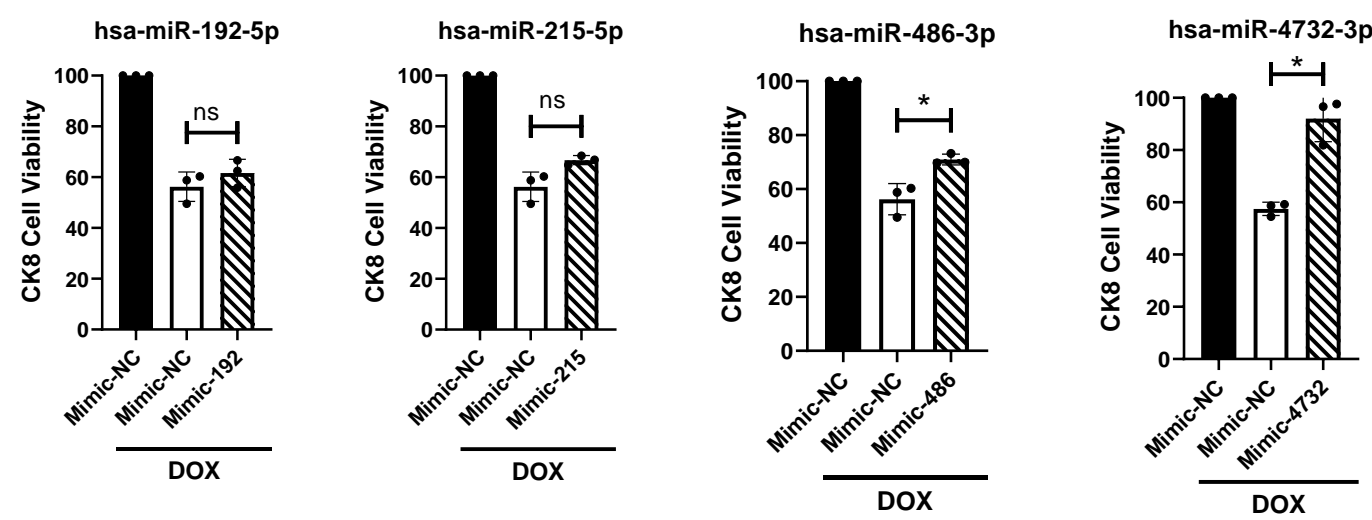

Figura 36: Efecto de la transfección de miRNA a una concentración de 20nM en la viabilidad de cardiomiocitos en un tratamiento de $0,1 \mu \mathrm{M}$ de doxorrubicina durante 48 horas. El efecto terapéutico fue comparado con cardiomiocitos transfectados con un control negativo a una concentración de 20 $\mathrm{nM}(\mathrm{NC})(\mathrm{N}=3, * \mathrm{p}<0,05)$. La barra inferior con la leyenda "DOX" indica que las condiciones que representan la segunda y la tercera barra han sido tratadas con doxorrubicina en contraposición con la primera barra.

\subsection{La transfección del miRNA 4732-3p no ejerce un efecto proliferativo en líneas de cáncer de mama}

Estudios anteriores ya han demostrado el papel de los miRNAs 148a, 30b, 150 y 486 en el tratamiento de la cardiotoxicidad por antraciclinas, sin embargo, el papel del miRNA 4732-3p no se encuentra ampliamente estudiado y no se conocen sus efectos en la regeneración cardiaca. Una de las principales limitaciones de este miRNA como tratamiento puede darse si, a pesar de aumentar la viabilidad de los cardiomiocitos, también es capaz de aumentar la viabilidad en las células cancerígenas. Por ello es de vital importancia que todo tratamiento en el que se observa una protección celular o un aumento de viabilidad sea testado para no ejercer este mismo efecto en las células cancerígenas. Por ello se tomaron las líneas de MDA-MB-231 y MCF7 las cuales fueron transfectadas con este miRNA a la misma dosis efectiva que usamos en el apartado anterior. Los resultados demuestran que el miRNA 4732-3p no ejerce su mecanismo protector en estas células asegurando de esta manera que un incremento artificial de este miRNA a nivel sistémico no provocaría un crecimiento tumoral. 

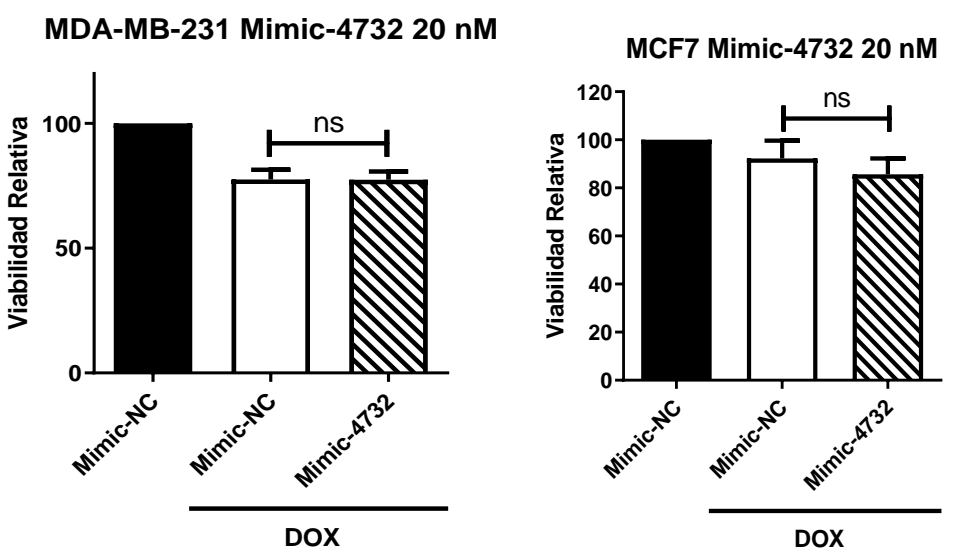

Figura 36: Efecto de la transfección de miRNA a una concentración de $20 \mathrm{nM}$ en la viabilidad de las células cancerígenas MDA-MB-231 y MCF7 en un tratamiento de $0,1 \mu \mathrm{M}$ de doxorrubicina durante 48 horas (DOX). El efecto terapéutico fue comparado con células cancerígenas transfectadas con un control negativo a una concentración de $20 \mathrm{nM}(\mathrm{NC})(\mathrm{N}=3, * \mathrm{p}<0,05)$

6. Potencial terapéutico de las vesículas extracelulares derivadas de MSC-TERT y miRNA 4732-3p en el daño por isquemia.

Una vez determinado el efecto de las EVs en el daño por isquemia reperfusión se plantea la posibilidad de que estas vesículas, así como el miRNA 4732-3p sean funcionales en otros tipos de daño centrado en la producción excesiva de ROS. Como se ha comentado en el apartado de introducción, la cardiopatía isquémica es una de las enfermedades de mayor importancia en todo el mundo. Por este motivo centramos la atención del estudio en la comprobación tanto del miRNA 4732-3p y las EVs derivadas de MSCs.

\subsection{Las vesículas derivadas de MSC-TERT así como el miRNA 4732-3p reducen el número de cardiomiocitos en estado de apoptosis después de un periodo isquémico}

En primer lugar, evaluamos el papel de las vesículas en el daño por isquemia y como afecta la liberación de su contenido mediante electroporación. Como modelo in vitro usamos una deprivación de oxígeno y glucosa durante 6 horas como se explica en los materiales y métodos de este trabajo (OGD). Como muestra la figura las vesículas extracelulares añadidas al principio del procedimiento ejercen un efecto protector en los cardiomiocitos. Además, el vaciado de estas vesículas mediante 3 pulsos de electroporación a $300 \mathrm{~V}$ hace que pierdan esta capacidad terapéutica mientras que la introducción del miRNA-4732-3p en las vesículas recupera este efecto. A su vez, se 
comprobó mediante una transfección con el miRNA 4732-3p que este es capaz de replicar el efecto tanto de las vesículas sin modificar tanto como aquellas a las cuales se les introduce de manera artificial el miRNA. Por ello estos liposomas con el miRNA 4732-3p se plantean como una posible terapia que compararemos con las EVs en los siguientes apartados.

A)

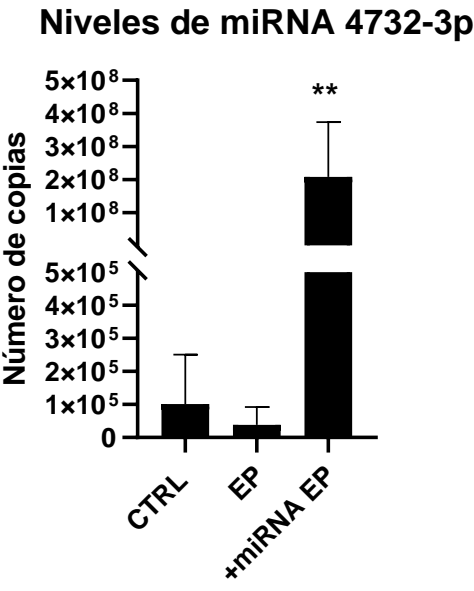

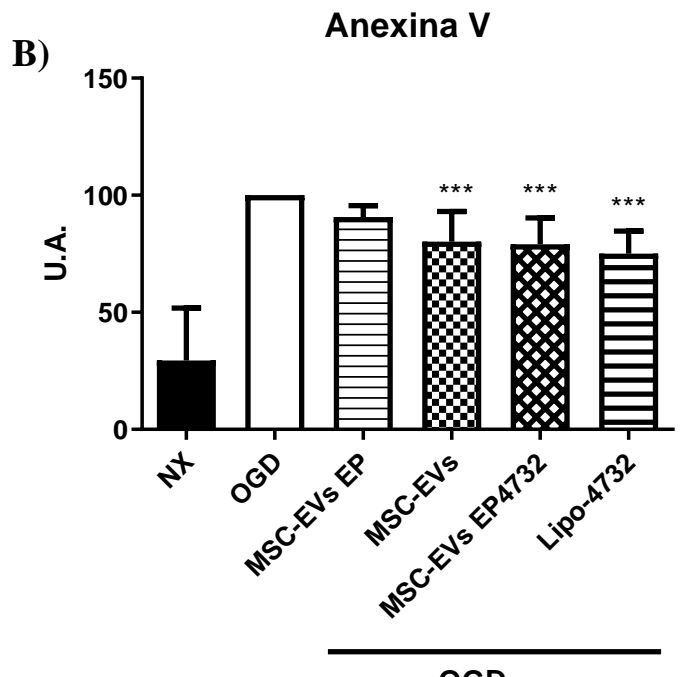

OGD

Figura 37: A) Niveles de miRNA en las vesículas extracelulares en condiciones esntadar (CTRL) sometidas a la electroporación (EP) o la electroporación con 20nM de mimic de miR-4732-3p (+miRNA EP) B) Efecto de las vesículas y miRNAs en el daño por isquemia reperfusión durante 6 horas (OGD) en la cantidad de células en apoptosis medido por citometría de flujo usando el kit de anexina V. En la gráfica se muestra grupos de cardiomiocitos a los cuales se les ha añadido EVs (MSC-EVs), aquellos donde las vesículas han sido electroporadas mediante tres pulsos a 300V para vaciar su contenido (MSC-EVs EP) y aquellas que en la electroporación se ha añadido una concentración de 20nM de mimic de hsa-miR 4732-3p en la electroporación(MSC-EVs EP4732) y cardiomiocitos tratados con el miRNA 4732-3p en liposomas (Lipo-4732). (N=3,***p<0.001)

\subsection{El miRNA 4732-3p y las MSC-EVs reducen los niveles de estrés oxidativo en cardiomiocitos durante la isquemia}

En el apartado anterior queda demostrado que las vesículas eletroporadas pierden su potencial terapéutico y que este se recupera cuando añadimos el miRNA 4732-3p en su interior. Este efecto a su vez se replica utilizando vesículas artificiales mediante el uso del reactivo lipofectamina 3000. Por este motivo a partir de este experimento utilizaremos la lipofectamina en lugar de vesículas electroporadas con el miRNA debido a la mayor capacidad de producción, la homogeneidad que representa el uso de liposomas.

Una vez que queda demostrado que el miRNA 4732-3p dentro de las vesículas puede ejercer un efecto protector en los cardiomiocitos. Generamos cardiomiocitos con una 
sobreexpresión de este miRNA por transfección y los sometemos al modelo de OGD. Los resultados demuestran que tanto las EVs de MSC-TERT como la transfección del miRNA generan una reducción del ROS así como una menor actividad de la lactato deshidrogenasa (LDH). Las pruebas de viabilidad mediante el kit CCK8 muestran una leve mejora significativa en el caso de las MSC-TERT sin embargo en el caso del miRNA 4732-3p no muestra mejoras quizá debido a la sensibilidad de la técnica.

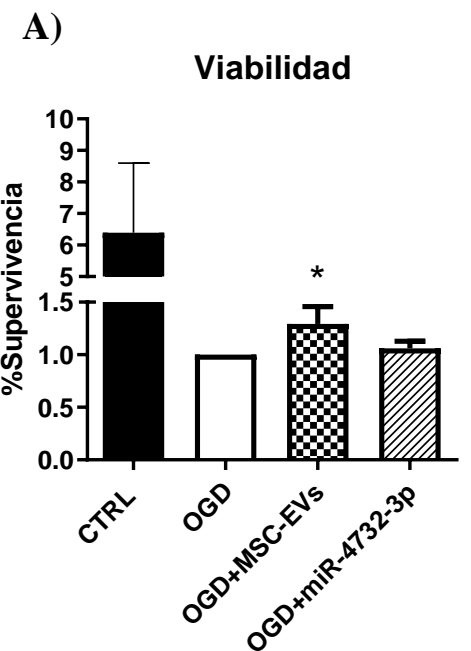

B)

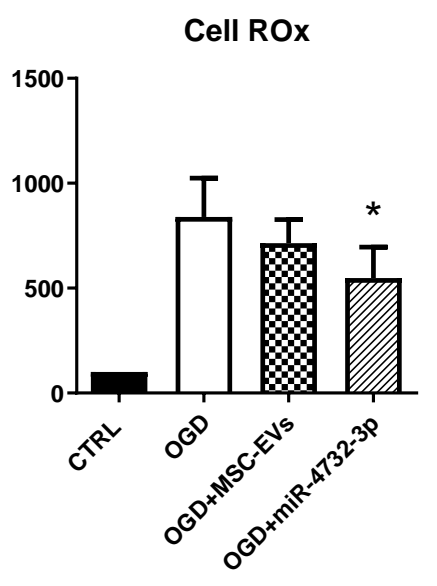

C)

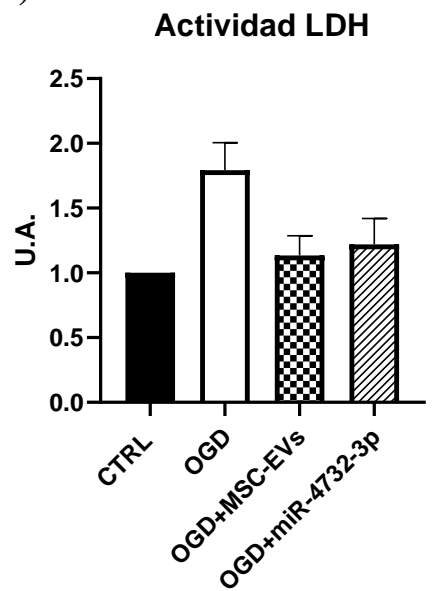

Figura 38: Efecto de las vesículas y miRNAs en el daño por deprivación de oxígeno y nutrientes durante 6 horas (OGD) en la viabilidad y la producción de ROS. En la gráfica se muestra grupos de cardiomiocitos a los cuales se les ha añadido EVs a una concentración de $15 \mu \mathrm{g} / \mathrm{mL}$ (MSC-EVs), aquellos donde se ha añadido el mimic por transfección a una concentración de $20 \mathrm{nM}$ utilizando el reactivo Lipofectamine 3000(+miR-4732-3p). (N=3, $\left.{ }^{*} \mathrm{p}<0.05\right)$ A) Gráfica con los resultados de viabilidad medida mediante el kit CCK8 B) Gráfica de los resultados de CellRox ${ }^{\circledR}$ medidos por intensidad de fluorescencia en citometría de flujo C) Gráfica de los niveles de lactato deshidrogenasa (LDH)medida por el kit "Citotoxicity detection kit" Roche.

\subsection{Variación de marcadores celulares en cardiomiocitos tratados con MSC-EVs y miRNA 4732-3p}

Con el propósito de dilucidar en parte el mecanismo por el cual las EVs reducen el nivel de células apoptóticas se estudiaron las expresiones de ciertos marcadores asociados con este daño. Para ello se evaluó mediante WB la expresión de las proteínas asociadas a la apoptois Cleavaged Cas3 (C.Cas3) y la proteína asociada a la comunicación celular en cardiomiocitos conexina 43. En la figura se puede observar una marcada reducción en la cantidad de Cleavaged Cas3 en el caso de los cardiomiocitos tratados con EVs-TERT y hsa-mIR-4732-3p. A su vez el tratamiento con EVs resulta en un aumento de la proteína conexina 43 de vital importancia en la 
comunicación celular entra cardiomiocitos sin modificaciones en los cardiomiocitos tratados con el miRNA.
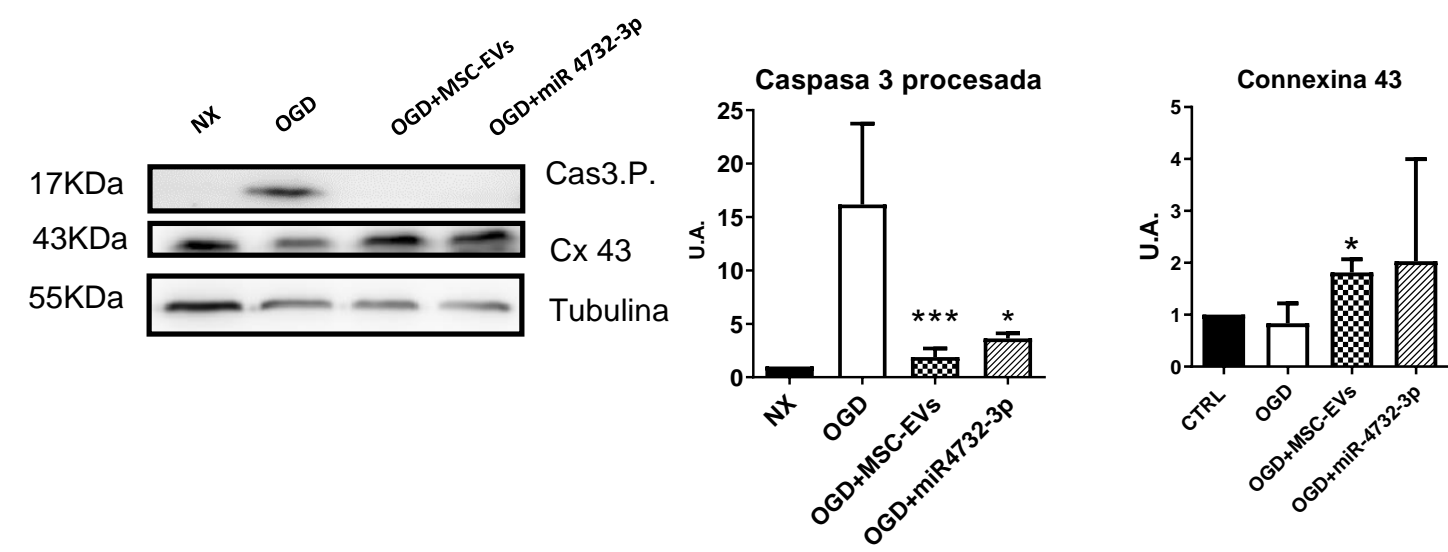

Figura 39: Efecto de las vesículas y miRNAs en el daño por deprivación de oxígeno y nutrientes durante 6 horas(OGD)en la expresión de marcadores de apoptosis como la Caspasa 3 procesada (Cas3.P)y Conexina 43 (Cx43). En la gráfica se muestra grupos de cardiomiocitos a los cuales se les ha añadido EVs (+MSC-EVs), aquellos donde se ha añadido el mimic por transfección a una concentración de 20nM utilizando el reactivo Lipofectamine 3000(+miR4732-3p). Los resultados han sido normalizados frente a la cantidad de proteína control de carga $\alpha$ tubulina. $\left(\mathrm{N}=3,{ }^{*} \mathrm{p}<0.05\right)$

\subsection{Las vesículas derivadas de MSC-TERT ejercen una protección frente a la perdida de contracción de los cardiomiocitos in vitro}

Debido al aumento en la cantidad de conexina 43 se planteó la posibilidad de que las EVs ejercieran un efecto protector en la producción de contracciones cardiacas durante la isquemia. Para ello los cardiomiocitos neonatales de rata se siembran a una alta confluencia y se cuenta la cantidad de latidos que generan por minutos. Durante el periodo de isquemia se monitoriza esta cantidad de latidos, como se puede observar en la figura el número de contracciones por minuto cae drásticamente durante las primeras horas de isquemia llegando a un número mínimo de contracciones en las que se mantiene durante las últimas horas del proceso. Las vesículas protegen de la pérdida de contractilidad en los cardiomiocitos primarios en estas últimas horas mientras que en el caso del miRNA 4732-3p se puede ver cierto efecto terapéutico, sin embargo, no es significativamente mejor que las células control. 

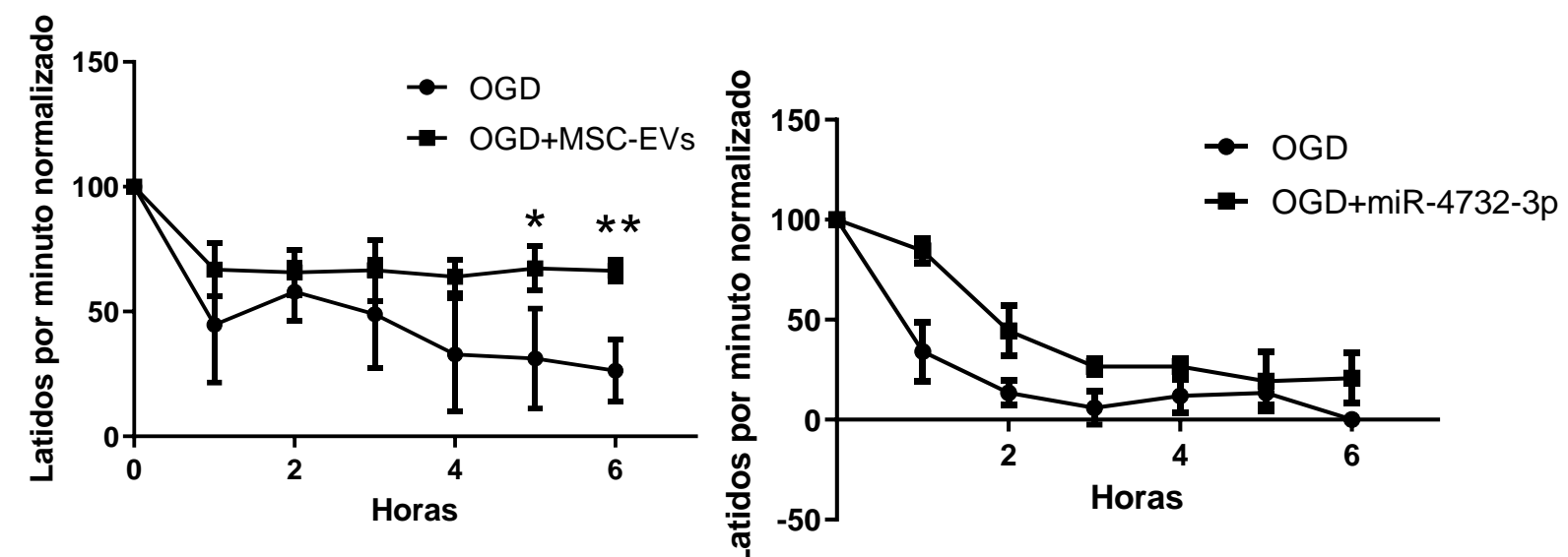

Figura 40: Efecto de las vesículas y miRNAs en el daño por deprivación de oxígeno y nutrientes durante 6 horas (OGD)en el mantenimiento de las contracciones in vitro. Se miden durante las horas de isquemia como varían las contracciones sincrónicas en la placa de cultivo siendo normalizadas al número de contracciones en Normoxia. En estas gráficas se comparan cardiomiocitos control frente aquellos a los cuales se les añade EVs a una concentración de $15 \mu \mathrm{g} / \mathrm{mL}$ y cardiomiocitos transfectados con mimic de miRNA 4732-3p a una concentración de 20nM. $\left(\mathrm{N}=3,{ }^{*} \mathrm{p}<0.05,{ }^{* *} \mathrm{p}<0.01\right)$

\subsection{El tratamiento con miRNA 4732-3p disminuye los marcadores de fibrosis $\alpha$-SMA y Col1A}

Como previamente se ha descrito, los procesos de fibrosis son de vital importancia después de un periodo de isquemia ya que dependiendo de si se da una fibrosis demasiado exacerbada esto contribuirá a una pérdida de área de crecimiento de cardiomiocitos que será ocupada por miofibroblastos así como su matriz extracelular producida. En este experimento tratamos los fibroblastos con TGF-b citoquina que es liberada durante la isquemia y que induce la transformación de los fibroblastos en miofibroblastos. Como puede verse en las siguientes imágenes el tratamiento con TGF-b induce un aumento significativo de la producción de $\alpha$-SMA. El tratamiento con EVs reduce singificativamente la expresión de $\alpha$-SMA pero no la producción de COL 1 A mientras que el tratamiento con el miRNA 4732 si reduce de manera significativa estos dos marcadores. 

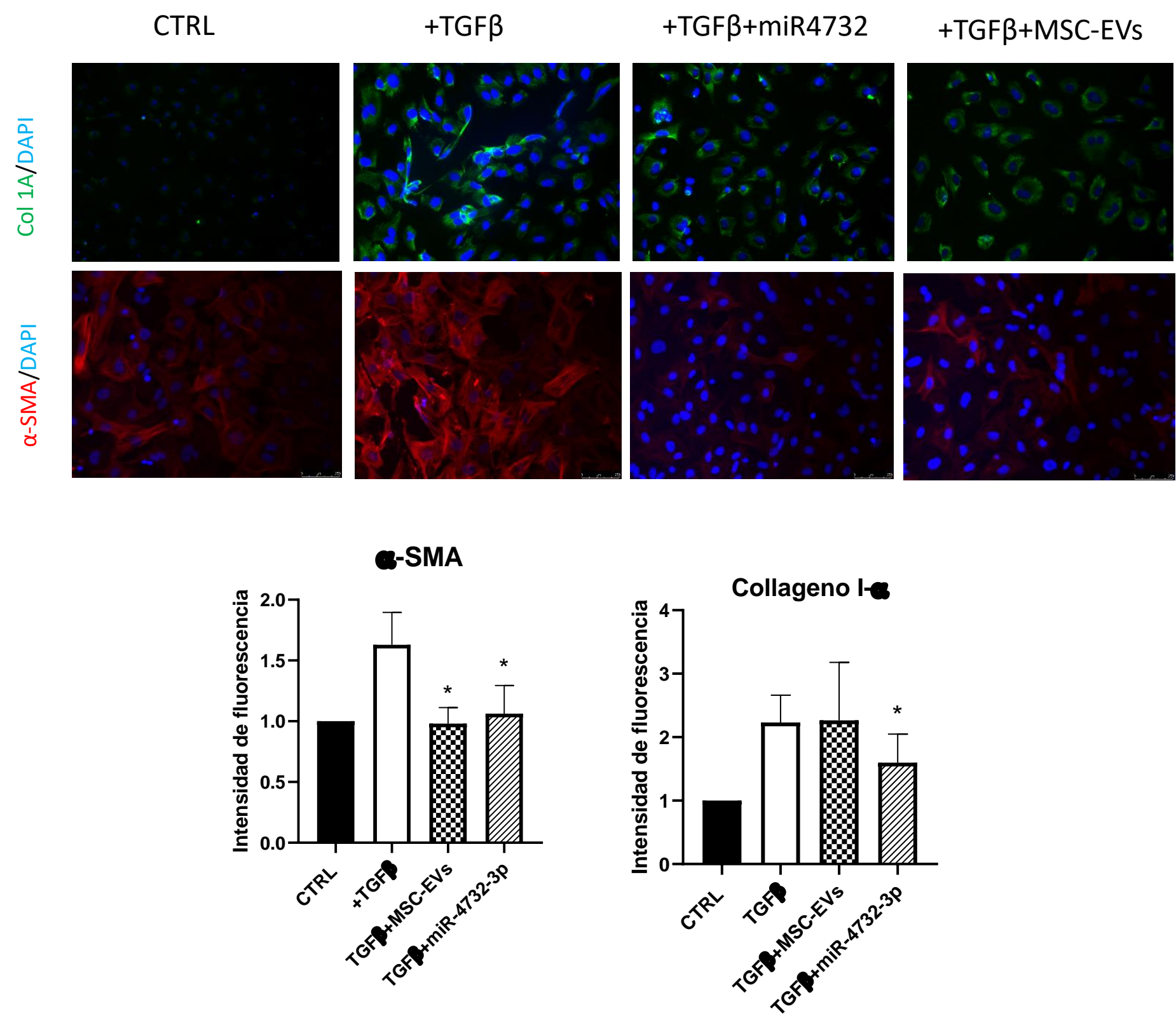

Figura 41: Efecto de las vesículas y miRNAs en la expresión de $\alpha$-SMA y colágeno. Para simular el efector pro-fibrótico los fibroblastos cardiacos se estimularon con TGF- $\beta$ durante 24 horas tras los cuales se evalúa por inmunofluorescencia la presencia de $\alpha$-SMA y colageno 1A. Se compararon fibroblastos sin tratar (CTRL), fibroblastos tratados con TGF- $\beta$ (+TGF- $\beta$ ), fibroblastos tratados con TGF- $\beta$ y transfectados a una concentración de 20nM con el mimic del miRNA 4732 (+miR-4732)y fibroblastos tratados con TGF- $\beta$ y EVs derivadas de MSC a una concentración de $15 \mu \mathrm{g} / \mathrm{mL}(+\mathrm{MSC}-\mathrm{EVs}) .(\mathrm{N}=3 * \mathrm{p}<0.05)$ 


\subsection{El tratamiento con el miRNA 4732-3p induce una menor movilidad de los fibroblastos}

Para testar la capacidad invasiva de los fibroblastos, testamos mediante un experimiento de cerramiento de herida su movilidad. Los fibroblastos fueron tratados con TGF-B para simular la señalización post-isquemia. Como puede observarse en la figura aquellos fibroblastos tratados con esta citoquina tienden a aumentar su movilidad generando una cicatrización más rápida de la herida simulada. También puede observarse que el tratamiento con el miRNA 4732 genera una reducción de la movilidad con respecto a su control y por lo tanto una mayor área libre de fibroblastos pasadas 24 horas.
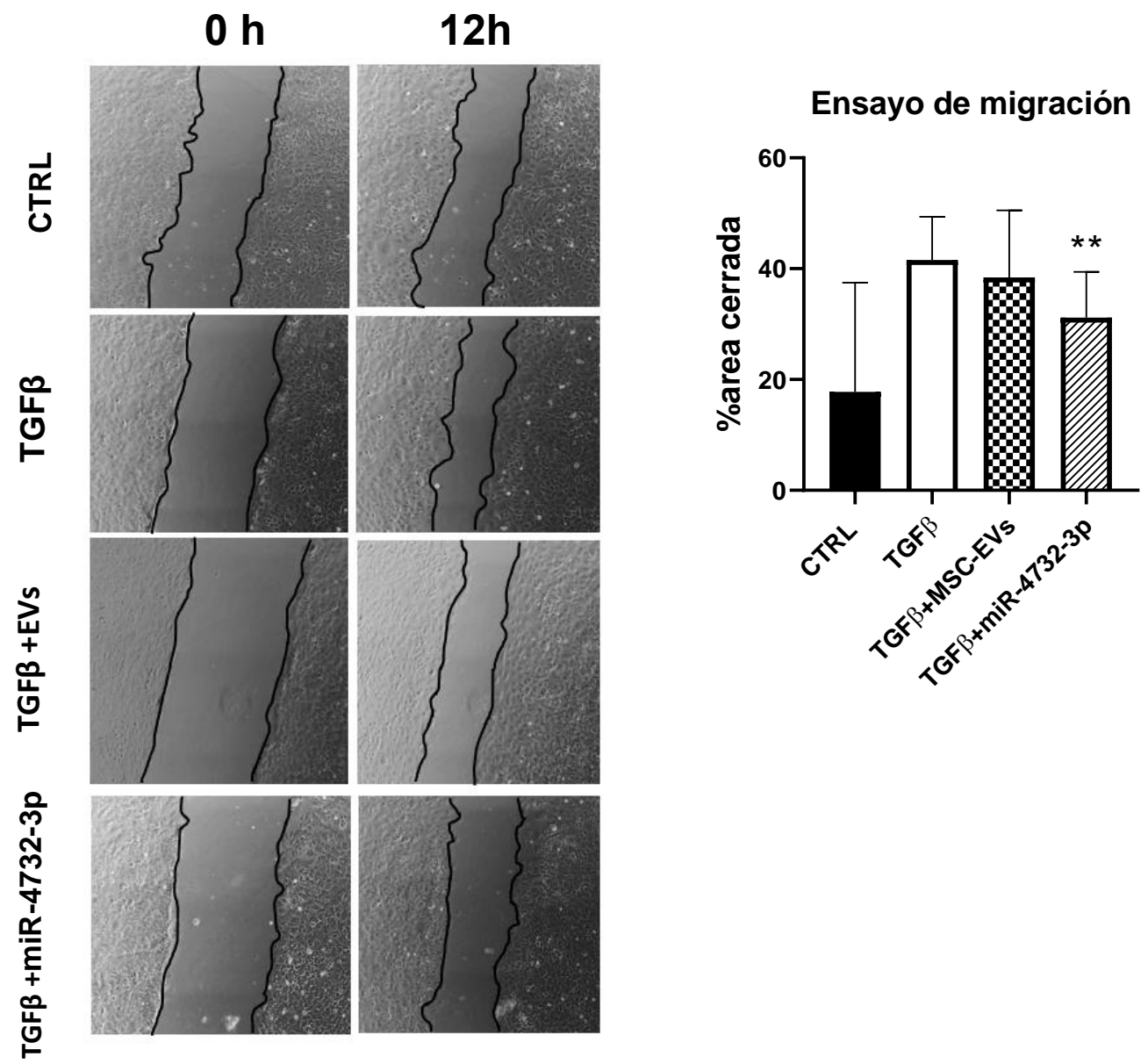

Figura 42 : Efecto delas vesículas y miRNAs en la capacidad de migración. Para simular el efector profibrótico los fibroblastos cardiacos se estimularon con TGF- $\beta$ durante 24 horas tras los cuales se evaluó el área de herida ocupada por los fibroblastos. Se compararon fibroblastos sin tratar (CTRL), fibroblastos tratados con TGFB (+TGFB), fibroblastos tratados con TGF- $\beta$ y transfectados a una concentración de $20 \mathrm{nM}$ con el mimic del hsa-mIR 4732 (+miR4732)y fibroblastos tratados con TGF- $\beta$ y EVs derivadas de MSC a una concentración de $15 \mathrm{ug} / \mathrm{mL}(+\mathrm{MSC}-\mathrm{EVs}) .(\mathrm{N}=6 * * \mathrm{p}<0.01)$ 


\subsection{El miRNA 4732 aumenta la angiogénesis in vitro en células endoteliales}

Los procesos de angiogénesis son de vital importancia en la regeneración cardiaca después de un proceso de isquemia. Por ello hemos querido averiguar si las células endoteliales sometidas a un proceso de limitación de nutrientes son capaces de generar una mayor cantidad de vasos al ser tratadas con las EVs o con el miRNA 4732. Los resultados demuestran que el miRNA 4732 es capaz de generar una mayor cantidad de estructuras tubulares así como una mayor longitud de estos. Además, se puede observar un aumento de los puntos de ramificación en estas células transfectadas con el miRNA 4732. No se observan diferencias en cuanto al perímetro de las mayas .

CTRL

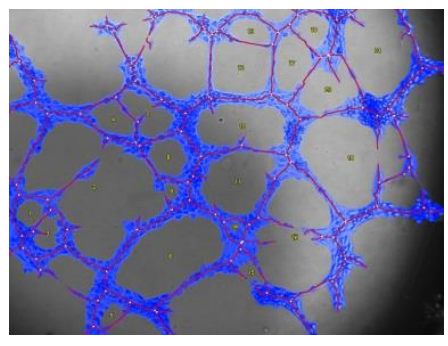

GD

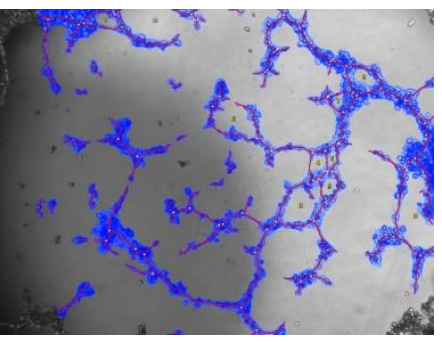

GD+EVs

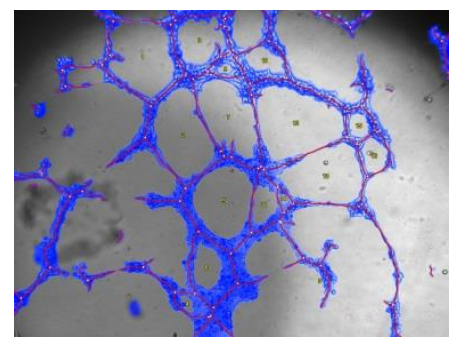

GD+miR-4732

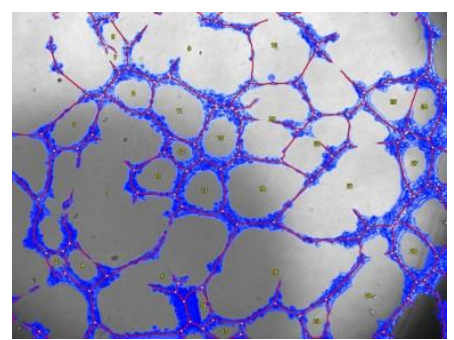

Tubos Totales

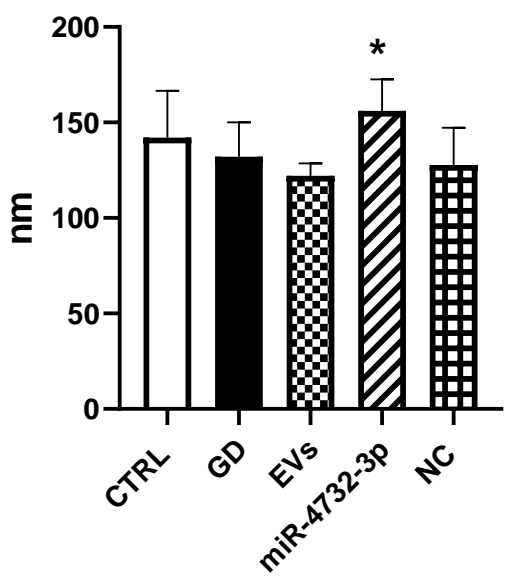

Longitud total de tubos

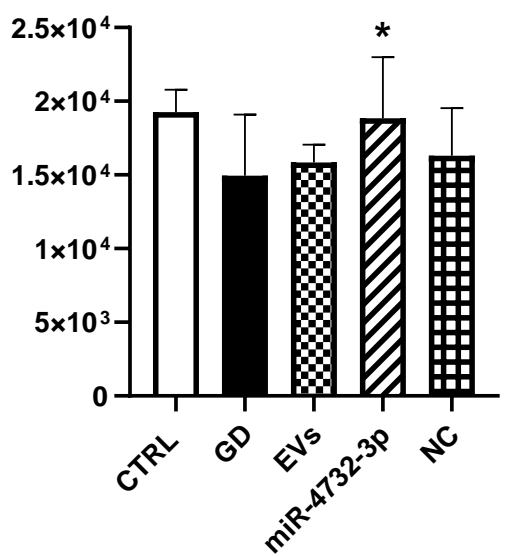

Puntos de ramificación

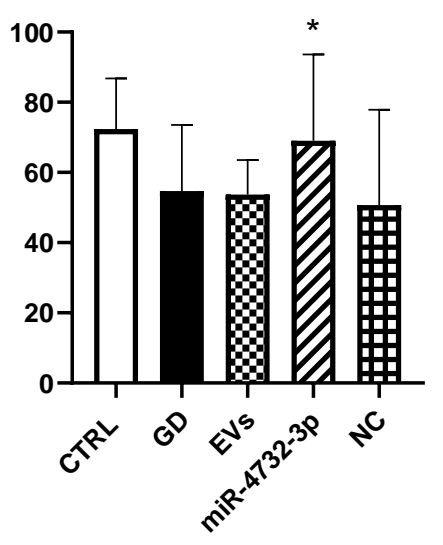

Figura 43: Efecto de las vesículas y miRNAs en la angiogénesis in vitro. Para simular un proceso similar a la isquemia las células se trataron con un medio sin glucosa (GD) y $1 \%$ de FBS, el resto de las condiciones fueron además tratadas con $15 \mu \mathrm{g} / \mathrm{mL}$ de EVs, (EVs) $20 \mathrm{nM}$ de concentración de mimic del miRNA-47323 p(mir-4732-3p) y 20nM de concentración del mimic control negativo (NC). Las imágenes fueron analizadas mediante el software online Wimasis 


\subsection{El miRNA 4732-3p induce angiogénesis en modelo in vivo}

Para confirmar el efecto angiogénico del miRNA-4732-3p in vitro se llevó a cabo el siguiente experimento in vivo en el cual se inyecta $350 \mathrm{uL}$ de Matrigel ${ }^{\circledR}$ a ratones atímicos de manera subcutánea en las extremidades traseras. Los animales se dividen en 4 grupos uno de los cuales el matrigel se mezcla con PBS, y otro con mimic control a una dosis de $20 \mu \mathrm{g}$ de miRNA. Al grupo a testar el miRNA se le inyecto mimic del miRNA 4732-3p a una dosis de $20 \mu \mathrm{g}$ mientras que al grupo control positivo se inyecto FGF a una concentración de $100 \mathrm{ng} / \mathrm{mL}$ junto con $20 \mathrm{U}$ de heparina. Una vez inyectado el matrigel los animales fueron sacrificados en un periodo de 15 dias donde se extrajo el plug de matrigel, se fijó con PFA al $4 \%$ y posteriormente fue embebido en parafina y cortado en rodajas de 0,5um. Sobre estas rodajas se llevó a cabo una tinción antiCD31 para testar la presencia de células endoteliales. Como se muestra en las fotos del plug al cabo del periodo de 15 días se puede observar una significativa vascularización del plug en el caso de los ratones tratados con el miRNA y el FGF. Sin embargo esta vascularización no se observa en el caso de los controles negativos. La tinción de CD31 muestra a su vez una mayor presencia de CD31 en los casos tratados con el miRNA poniendo de manifiesto el aumento de endotelio en los plugs.
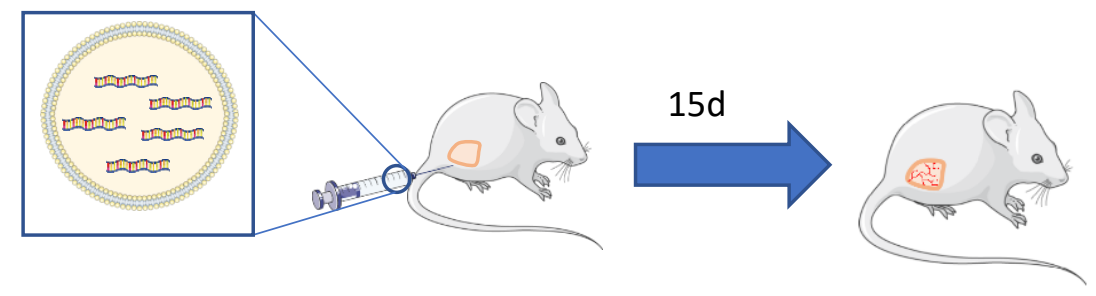

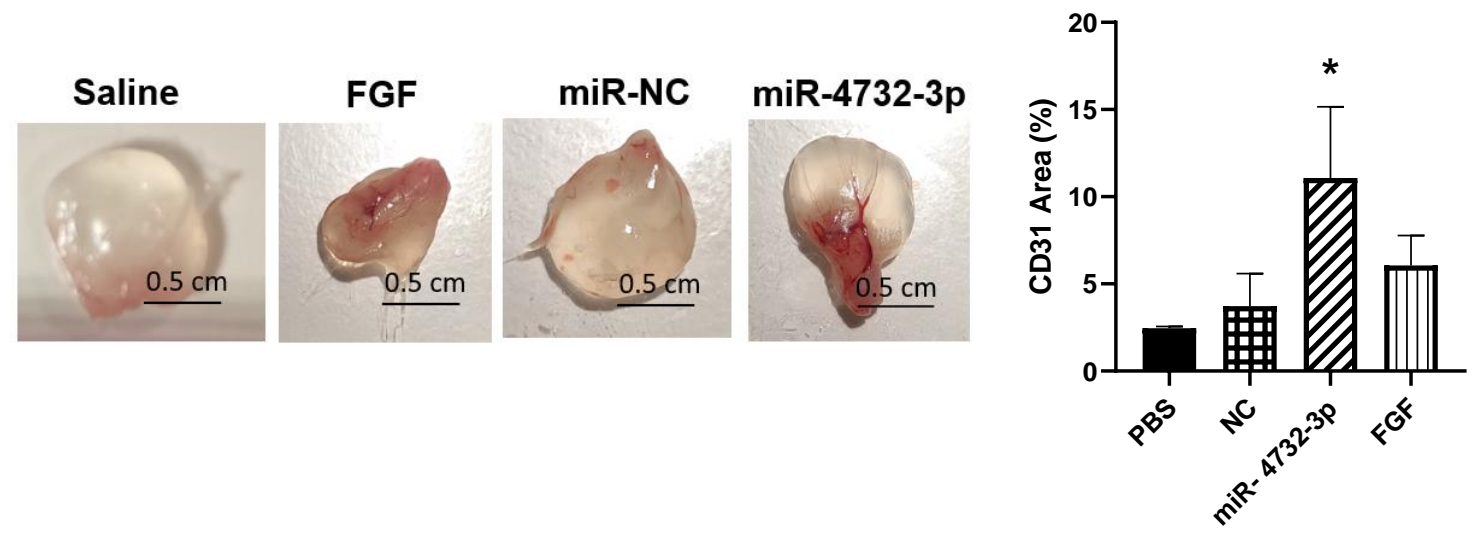




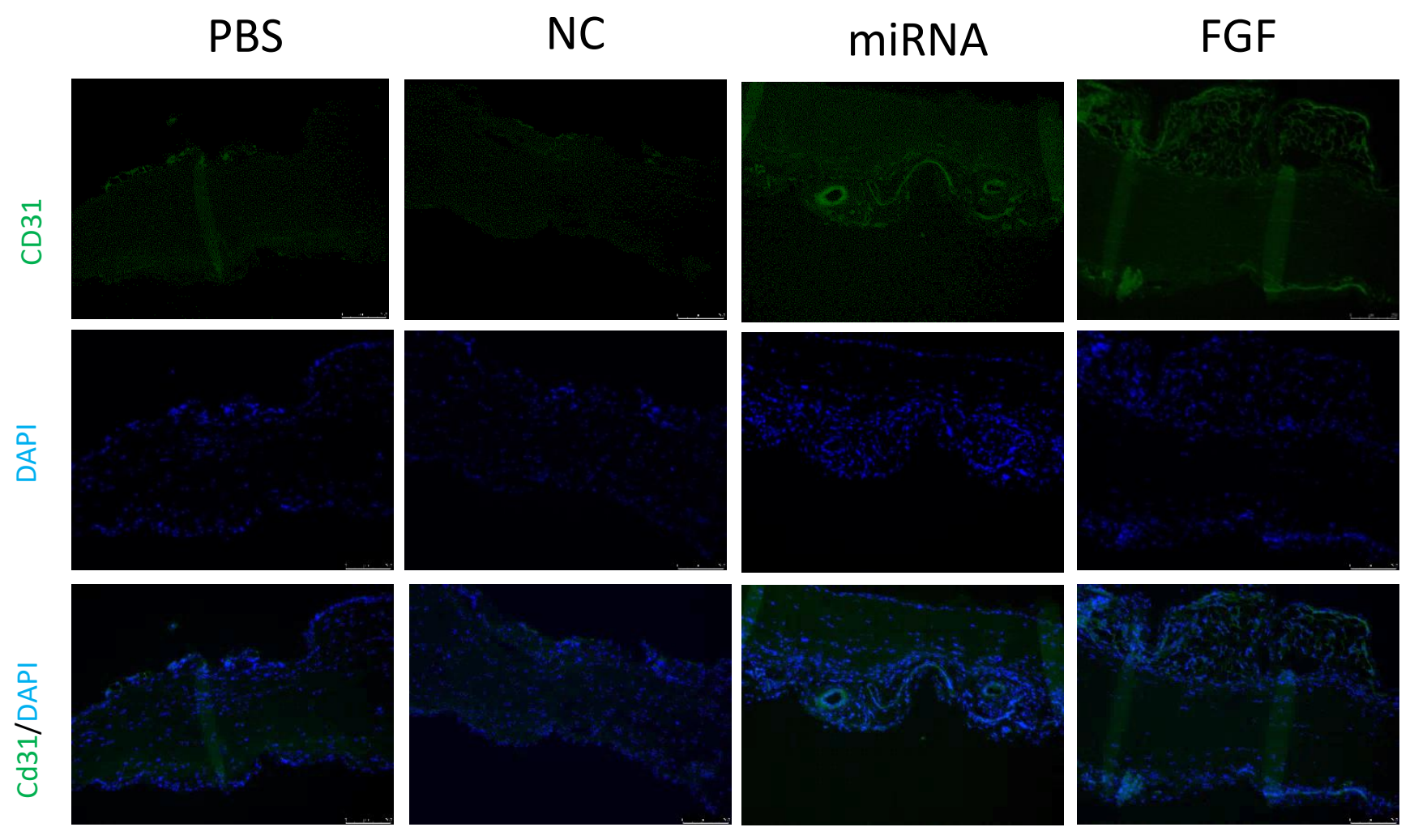

Figura 44 : Efecto del miRNA miRNA-4732-3p en la angiogénesis in vivo. A) Diagrama del proceso, los animales son inyectados de manera subdérmica con una mezcla de Matrigel® con el

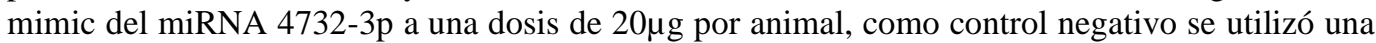
secuencia mimic negativa (NC) y PBS mientras que como control positivo se utilizó FGF a una concentración de $10 \mathrm{mg} / \mathrm{mL}+20 \mathrm{U}$ de heparina. Los ratones se sacrificaron a los 15 tras los cuales el plug se fija en PFA y se embebe en parafina y se corta B) Imágenes representativas de inmunfluorescencia de marcador de células endoteliales CD31 $\left(\mathrm{N}=5^{*} \mathrm{p}<0.05\right)$

\subsection{Efecto de las EVs y el miRNA 4732-3p en el modelo de isquemia in vivo}

Como última prueba, se estudió el efecto tanto del miRNA como de las vesículas en un modelo de infarto agudo de miocardio. Para ello se utilizaron ratas atímicas entre 200 y $250 \mathrm{~g}$ (Charles Rivers) las cuales son sedadas mediante Fentanilo e intubación con un flujo constante de sevofluorano. Una vez intubadas se efectúa sobre las ratas una apertura transtoraccica. Se retira el pericardio y se liga mediante una sutura quirurgica 6/0 la arteria coronaria descendente. El tamaño del infarto así como el éxito del mismo se comprueba in situ mediante cambio de color de la región infartada en el corazón de la rata. Seguidamente se inyectan los tratamientos en dos pinchazos en zonas periféricas al infarto. Uno de los grupos recibe $12,5 \mu \mathrm{L}$ de PBS en cada pinchazo, otro de ellos una dosis de 3,5E10 vesículas de MSC y el tercero una dosis de $25 \mu \mathrm{g}$ de 
mimic de miRNA 4732-3p formado un complejo liposomal mediante el reactivo Max Suppressor In Vivo RNA-LANCEr II (Bio Scientific). Las ratas fueron monitorizadas por ecocardiografía antes y 3 semanas después de la operación donde se midieron los parámetros de ventrículo izquierdo en diástole (VIDd) y ventrículo izquierdo en sístole (VIDs), el grosor de la pared anterior y posterior (PA, PP) en diástole y sístole, y el área diastólica final (ADF) y área sistólica final (ASF). El cambio porcentual de área se midió mediante la fórmula [(ADF-ASF)/ADF]x100. La fracción de acortamiento (FA) se midió mediante la fórmula [(VIDd-VIDs)VIDd]x100.
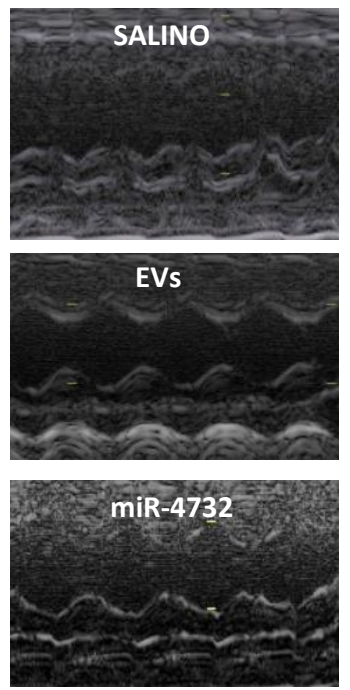
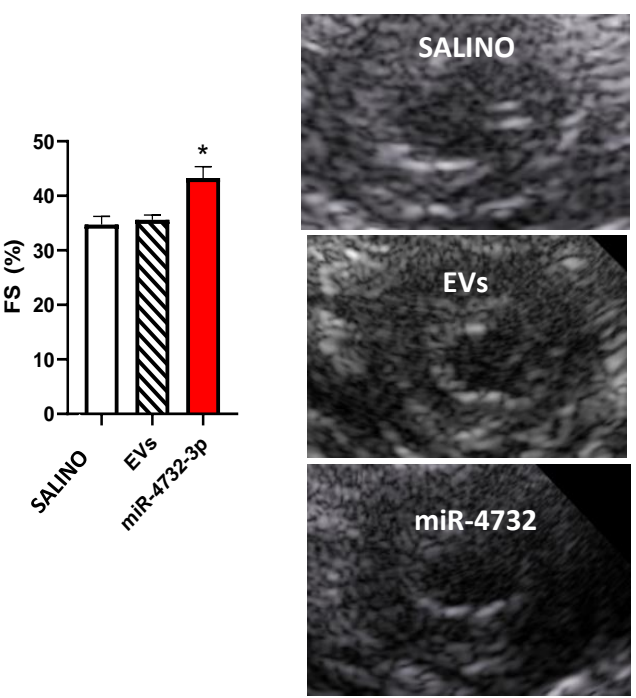

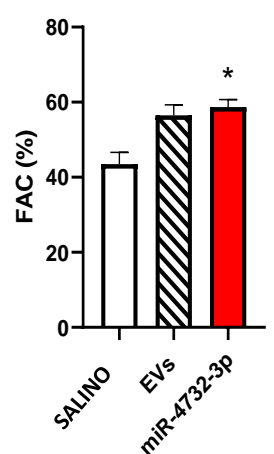

Figura 45: Efecto del miRNA hsa-miR-4732-3p en la cardioprotección in vivo. Los animales se dividen en 3 grupos (salino=PBS, EVs=3,5E10 vesículas en dos dosis de 12,5 $\mu \mathrm{L}$ intracardiaco, y miRNA $4732-3 p=25 \mu \mathrm{g}$ de mimic del mirRNA $4732-3 p$ en dos dosis de $12,5 \mu \mathrm{L}$ intracardiacos $\mathbf{A}$ ) Imágenes representativas de las ecografías en modo M 3 semanas después de la operación donde se calcula la fracción de acortamiento a partir de las distancias del ventrículo izquierdo en sístole y diástole. B) Imágenes representativas de las áreas sistólicas de las ratas 3 semanas después de la operación con las que se calcula el cambio porcentual de área $(\mathrm{N}=5 * \mathrm{p}<0.05)$

Los resultados correspondientes a la fracción de acortamiento y cambio porcentual de área muestran una mayor diferencia de entre sístole y diástole en los animales tratados con el miRNA con respecto a los tratados con EVs o salino, lo cual refleja una mayor eficiencia en la contracción y por lo tanto una mejor función cardiaca. A continuación, podemos observar los resultados de la cuantificación del área necrótica después de realizar el infarto. Para este cometido las ratas fueron sacrificadas a las 3 semanas de ser sometidas a la operación, el corazón se fija por perfusión de PFA como se especifica en los materiales y métodos de este trabajo. Seguidamente el corazón se embebe en parafina y es cortado en secciones representativas de las diferentes alturas del infarto. Las secciones se tiñen mediante la técnica de tricrómico de Mason para 
detectar el área infartada en azul que fue calculada mediante el software de imagen Image J

PBS
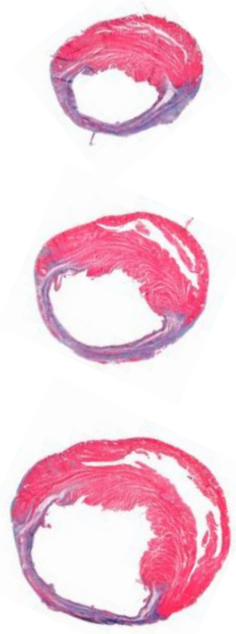

EVs
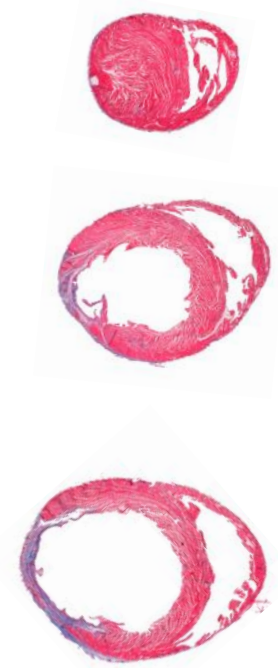

miR-4732-3p

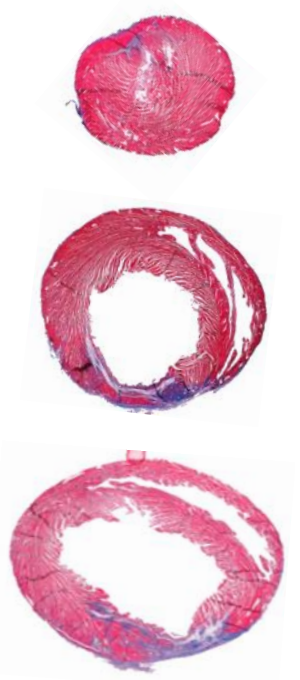

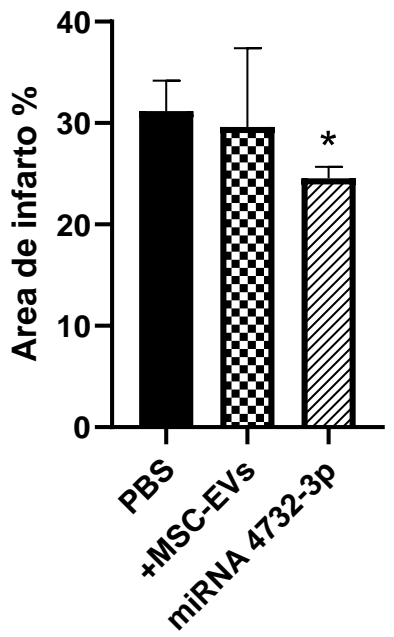

Figura 46 : Efecto del miRNA hsa-miR-4732-3p en la cardioprotección in vivo. Los animales se divideron en 3 grupos (saline $=\mathrm{PBS}, \mathrm{EVs}=3,5 \mathrm{E} 10$ vesículas en dos dosis de $12,5 \mu \mathrm{L}$ intracardiaco, y miRNA 4732-3p=25 $\mu \mathrm{g}$ de mimic del mirRNA 4732-3p en dos dosis de $12,5 \mu \mathrm{L}$ intracardiacos) A) Imágenes representativas de las secciones cortadas para la tinción de tricrómico de Mason donde el area de infarto se puede observar como tejido teñido en azul. B) Gráfico del área de infarto representado como porcentaje del ventrículo izquierdo infartado

Como puede observarse en la figura en los animales tratados con el miRNA podemos ver un área significativamente menor de infarto con respecto a los animales tratados con PBS. Este experimento corrobora los resultados in vitro anteriormente obtenidos planteando este miRNA como una posible terapia para este tipo de patología. 


\section{DISCUSIÓN}




\section{Las vesículas Extracelulares derivadas de cardiomiocitos juegan un papel importante en la comunicación intercelular}

Las células que se encuentran en el corazón, así como en la mayoría de los órganos presentes en seres multicelulares poseen una alta capacidad de comunicación ya sea entre sí mismas, así como como con otros tipos celulares. Esta comunicación es de vital importancia para poder responder de una manera eficaz a diferentes cambios que puedan ocurrir en el organismo con objeto de mantener una homeostasis en el funcionamiento del órgano. Para este fin, las células cuentan con una gran cantidad de mecanismos entre los cuales se destaca la liberación de vesículas extracelulares. Con el objeto de discernir como se ejerce esta comunicación celular en el contexto cardiaco llevamos a cabo una serie de experimentos aislando vesículas de una línea inmortalizada de cardiomiocitos en diferentes condiciones de cultivo obteniendo una serie de resultados que se discuten a continuación.

El primer resultado destacable que se encuentra en la comunicación vesicular es que la cantidad de vesículas extracelulares liberadas en condiciones hipóxicas aumentan en hasta 2,3 veces. Este fenómeno puede responder al hecho de que, en condiciones de estrés, los cardiomiocitos liberen una mayor cantidad de vesículas que pueden contener proteínas u otros componentes que ayuden a resolver la situación anormal producida en este momento. Este aumento observado, sin embargo, no altera la forma o marcadores de las vesículas, las imágenes de microscopía electrónica demuestran que ambas vesículas poseen la morfología y tamaño característica de vesículas. Las tetraspaninas como marcadores visualizados por WB CD9, Alix y TSG101 se mantienen sin variación entre los diferentes estados de aislamiento. Estas observaciones se encuentran en consonancia con artículos previos que demuestran como la hipoxia aumenta la concentración de EVs liberadas por cardiomiocitos ${ }^{213}$.

Seguidamente se estudia el contenido de dichas vesículas en condiciones de hipoxia y normoxia para comprobar su posible alteración. En primer lugar, se demuestra que tanto las vesículas derivadas de un estado hipoxia como las vesículas derivadas de cardiomiocitos cultivados en condiciones estándar, muestran una gran parte de su proteoma orientado a proteínas encargadas en la organización de la matriz extracelular, angiogénesis, migración celular y otros procesos relacionados a su vez con la adhesión celular. A pesar de estar presentes en ambos tipos de EVs estas proteínas se encuentran sobrerepresentadas en las EVs derivadas del estado hipóxico. En un estudio llevado a cabo por S. Roura et al. se comprobó que en vesículas circulantes en plasma en pacientes con cardiomiopatía dilatada se encontraban sobrerepresentadas frente a los 
controles proteínas en vesículas relacionadas con la matriz extracelular como fibrinógeno o serotransferrina, comprobando de esta manera como el tejido cardiaco respondía con esta serie de proteínas a estados patológicos. ${ }^{214}$

Además, se comprobó un cambio en la composición proteica de las vesículas liberadas por cardiomiocitos cuando se sometían a eventos de hipoxia, poniendo de manifiesto que la célula es capaz de reconocer este estado y ajustar su comunicación celular en función de él. En cuanto al contenido diferencial, las vesículas derivadas de cardiomiocitos en estado de hipoxia contenían una mayor cantidad de proteínas con actividad de chaperona relacionadas con la amioacilación de proteína. Estos resultado se apoyan en otros estudios que ha demostrado que después de un procesos de isquemia en miocitos las vesículas liberadas poseen una mayor cantidad de la proteínas involucradas en la actividad chaperona como HSP60 $213,215$.

Por otra parte, nuestros experimentos ponen de manifiesto que, a la dosis que hemos trabajado de vesículas extracelulares, no se produce ningún efecto de crecimiento sobre las diferentes poblaciones cardiacas. Aunque un efecto proliferativo de algunas de las poblaciones cardiacas podría ser beneficioso en el caso de células endoteliales para la angiogénesis y los cardiomiocitos, en el caso de ejercer un efecto proliferativo sobre las poblaciones de fibroblastos podrían darse fenómenos de fibrosis indeseables para el funcionamiento del músculo cardiaco.

En los experimentos de captación de vesículas, cabe destacar la capacidad incrementada que tienen las poblaciones de células endoteliales de captar las vesículas extracelulares con respecto a las de fibroblasto. El hecho de que los cardiomiocitos en estado hipóxico liberen más vesículas al medio extracelular y que estas sean captadas preferentemente por el endotelio revela que este tipo de tejido se encuentra equipado con una serie de mecanismos especializados para captar estas vesículas. Este resultado adquiere sentido teniendo en cuenta que para la mayoría de tejidos es necesario que las sustancias sean captadas por el endotelio antes del resto de células presentes en el tejido para llegar al mismo. Aunque se observan leves diferencias de captación entre las vesículas liberadas en hipoxia frente a las normales los resultados nos permiten hipotetizar que este estado no afecta en gran medida a los componentes que se encuentran en la superficie de las vesículas encargados de unirse a las membranas celulares para su captación.

Además de esta comunicación preferencial que existe entre cardiomiocitos y células endoteliales se observó mediante un ensayo de angiogénesis in vitro como la adicción de EVs derivadas de cardiomiocitos en estado de hipoxia (Hx-CM EVs) sobre células 
endoteliales reducía la formación de estructuras tubulares. Este resultado correlaciona con el análisis proteómico en el cual se encontraban proteínas relacionadas con la angiogénesis tanto en las Hx-CM-EVs como en las vesículas cultivadas en condiciones estándar (Nx-CM EVs), sin embargo, en estas últimas las proteínas relacionadas con la angiogénesis como pueden ser TGF $\beta$ y VEGF-C se encontraban enriquecidas con respecto a las Hx-CM EVs. Estos resultados contrastan con algunos previamente publicados en los cuales las condiciones hipóxicas inducen un aumento en la concentración de moléculas pro-angiogénicas en vesículas liberadas por las células endoteliales así como CPCs como pueden ser los miR-126 y miR-210216 217.

En los resultados obtenidos en el ensayo de estrechamiento de herida, podemos ver como las Hx-CM-EVs dan lugar a un mayor estrechamiento en el área abierta, promoviendo de esta manera una mayor migración en los fibroblastos. Estos resultados concuerdan con el efecto pro-fibrótico que encontramos después de que se origine una isquemia cardiaca orientado a un rápido cierre de la posible lesión. Resultados de similar índole han sido encontrados por otros investigadores, por ejemplo se ha demostrado que después de una sobrecarga de presión cardiaca en un modelo murino da lugar a una activación de los fibroblastos presentes tanto en la región dando lugar a aumentos en su migración y número ${ }^{218}$. Otros autores describen hasta un aumento del $63 \%$ de diferenciación de fibroblastos a miofibroblastos después de 30 min de deprivación de oxígeno con su respectivo aumento de fibras de $\alpha$-SMA así con una mayor capacidad de remodelado de la matriz extracelular ${ }^{219}$. Otro estudio llevado a cabo en ratones diabéticos $\mathrm{db} / \mathrm{db}$ encontraron presencia de miRNAs que se involucran en la expresión de MMP9 proteína en vesículas derivadas de cardiomiocitos. Esta proteína se encuentra a su vez altamente relacionada con el remodelado de la matriz extracelular y por lo tanto con la fibrosis que acompaña a los cardiomicitos. ${ }^{220}$

Con todos estos resultados podemos concluir que las células cardiacas ejercen una comunicación activa a través de las vesículas extracelulares y que esta comunicación se encuentra influenciada por el estado en el que se encuentra la célula secretora. Un estudio en profundidad de estos mecanismos podría dar lugar al desarrollo de unas terapias altamente dirigidas a las células cardiacas mediante el uso de vesículas de MSCs o creando vesículas artificiales que mimeticen el cargo o las proteínas de membrana que sean de interés para la terapia en cuestión. 


\section{Perfil diferencial de miRNAs en pacientes con cáncer de mama}

Una vez hemos puesto de manifiesto en el apartado anterior como las vesículas, así como su contenido muestran un papel de vital importancia en la comunicación intercelular, el estudio centra su atención en las posibles moléculas responsables de la comunicación que se encuentran dentro de las vesículas. Así, los miRNAs se postulan como uno de los posibles candidatos a ejercer dicha comunicación. Estas moléculas pueden encontrarse dentro de vesículas celulares pero también de manera libre en el torrente sanguíneo así como en diversos biofluidos como orina ${ }^{221}$, saliva ${ }^{222}$, liquido cefaloraquideo $^{223}$ o sudor $^{224}$.'

Estos miRNAs circulantes se encuentran altamente influenciados, al igual que la comunicación vesicular, por el estado de las células secretoras. Por este motivo, este apartado del trabajo ahonda en la búsqueda de un perfil de miRNAs característico de pacientes con tendencia a sufrir episodios de cardiotoxicidad derivada de antraciclinas. En la primera tabla que se muestra en los resultados podemos observar las diferentes características entre los pacientes divididos en la cohorte control (aquella que después del tratamiento no sufre episodios de cardiotoxicidad) frente a los pacientes casos (los que a lo largo del tratamiento vemos una caída de la FEVI por debajo del 55\%). Es de vital importancia estudiar todos los parámetros que se encuentran en la tabla ya que de esta manera evitamos posibles sesgos a la hora de elegir pacientes. Como podemos ver en la tabla no existen diferencias en los diversos parámetros que se pueden asociar con un amento de riesgo de patología cardiaca como pueden ser tabaquismo, obesidad o diabetes, por lo que podemos aumentar la seguridad de que las diferencias que posteriormente observamos se deben únicamente a la predisposición de sufrir cardiotoxicidad en lugar de otros factores.

Para evitar que las diferencias entre los perfiles de miRNAs se deban a los diferentes subtipos de cáncer entre pacientes en lugar del propio fenómeno de cardiotoxicidad, se incluyeron tanto en los grupos de casos como controles pacientes con los diferentes subtipos de cáncer. Además, y para apoyar esto, podemos observar que en el estudio del interactoma no se observa que los miRNAs diferencialmente expresados están relacionados con algún proceso de origen tumoral.

Una vez se obtienen a lo largo de los diferentes puntos temporales las muestras de las pacientes se lleva a cabo un estudio de secuenciación de miRNAs en el que se observa como varían los niveles de estas moléculas a lo largo del tratamiento. Para analizar los datos e intentar no limitar el estudio por el método de elección utilizado, se llevaron a 
cabo 3 manera de análisis diferentes. Solo un miRNA fue detectado como diferencialmente expresado por los 3 métodos el miRNA miR-4732-3p. Este miRNA se encuentra muy poco descrito en la bibliografía actual. En cierto estudio se encuentra este miRNA expresado en eritrocitos de primates en los cuales se encuentra regulando las proteínas SMAD2 y SMAD4. Estas proteínas inhiben la activación de la vía del TGF- $\beta$ lo que promueve una expansión eritroide ${ }^{225}$. Estas proteínas SMAD a su vez dan lugar a la regulación de genes como pai-1, p21,bim y bax ${ }^{226,227}$ que actúan como activadores de la apoptosis y la muerte celular ${ }^{228,229}$.

Curiosamente, también existen miRNAs de origen eritroide los cuales se han relacionado como marcadores de diversas patologías como el miRNA-92 o el miRNA 486-5p ${ }^{230}$ que aparecen en este estudio como miRNA diferencialmente expresados entre casos y controles. En el caso del miRNA 486-5p se ha encontrado que una inhibición de este miRNA da lugar a la protección de cardiomiocitos en el daño inducido por hipoxia ${ }^{231}$ mientras que otros autores reportan que la sobreexpresión de este miRNA reduce la apoptosis de cardiomiocitos y da lugar una mejora en la función cardiaca vía activación de $\mathrm{PTEN}^{232}$. En el caso del miRNA 92b se ha visto que se estimula en cardiomiocitos inducidos con angiotensina II para simular hipertrofia cardiaca $^{233}$.

En cuanto a los miRNAs 30b y 150 diversos artículos los han encontrado en vesículas circulantes así como relacionados ambos con procesos de angiogénesis en células de microvasculatura ${ }^{234-236}$. Otro artículo relaciona que pacientes con infarto de miocardio, fibrilación atrial o cardiomiopatía dilatada tiene el miRNA 150 infraexpresado, atribuyendose sus efectos terapéuticos a una represión directa de los genes proapoptóticos egr 2 y p2x7r en los cardiomiocitos ${ }^{237}$ Mientras que en el caso del miR 30b su efector terapéutico se basa en la reducción de ROS vía represión de la proteína Aven en el daño a cardiomiocitos sometidos a hipoxia ${ }^{238}$ y el remodelado ventricular ${ }^{239}$.

Los miRNAs 192 y 148a sin embargo se encuentran más relacionados con la fibrosis cardiaca y vascularización ${ }^{240}$, en el caso del miRNA 192 se encuentra comprobado que los niveles de este miRNA se asocian a la edad, también se ha visto una asociación con este miRNA y supervivencia en pacientes con cardiomiopatía isquémica ${ }^{241}$.Por otra parte se ha visto que el miRNA-148a se encuentra envuelto en la regulación del VEGF a través de la vía NRP1, jugando pues un papel importante en fenómenos de isquemia, retinopatías o vascularización de tumores ${ }^{242}$.

Otro aspecto importante que revelan los resultados de este estudio se obtiene a partir del análisis del interactoma en el que podemos ver involucrados bastante procesos 
relacionados con la patología cardiaca como pueden ser hipertrofia ventricular, dilatación ventricular, remodelado cardiaco, anormalidades en la distribución del sarcómero y fibrosis perivascular. Estos cambios a menudo se encuentran en relación con la re-expresión de genes que se expresan durante la gestación. En este caso podemos ver que la vía de Wnt se asocia con la formación cardiaca dando lugar a la expansión de diferentes progenitores cardiacos que dan lugar a la diferenciación de los cardiomiocitos. Alteraciones en esta vía, así como re-activaciones de esta durante el periodo adulto de una persona, pueden dar lugar a diversas patologías cardiacas incluyendo un aumento de riesgo de infarto, IC o hipertensión. En este estudio podemos ver una serie de miRNAs que se relacionan con la vía de Wnt como son el miRNA-30b, miRNA-148a y miRNA-4732-3p. Teniendo esto en cuenta, podemos hipotetizar que estos miRNAs se encuentran afectando a la vía de Wnt y por lo tanto afectando a procesos de apoptosis cardiaca y daño mitocondrial derivado de las antraciclinas.

Una vez se han seleccionado una serie de miRNAs como diferencialmente expresados se realiza una modelización mediante una ecuación que nos permite conocer el riesgo a sufrir estos episodios de cardiotoxicidad con una exactitud en torno al 83\% evaluando únicamente el perfil de miRNAs. Este tipo de algoritmos de predicción ya se han llevado a cabo utilizando otro tipo de moléculas o parámetros clínicos. Como se han mencionado en el apartado de introducción de este trabajo, se especula que parte del mecanismo de acción de la doxorrubicina ocurre a través del efecto de la misma sobre la topoisomerasa $2 \beta$ (Top2B). Ciertos estudios han demostrado que ratones a los cuales se les elimina el gen de expresión de esta proteína en cardiomiocitos no desarrollan una cardiotoxicidad derivada de antraciclinas. En el apartado clínico observaron que pacientes con una baja expresión de Top2B cardiaca tenían una menor susceptibilidad a sufrir fenómenos de cardiotoxicidad. La limitación de este estudio se centra en la necesidad de una biopsia cardiaca para cuantificar los niveles de esta proteína para calcular la susceptibilidad ${ }^{243}$. Aunque los propios autores plantean que se pueden observar los niveles de Top2B en leucocitos de sangre periférica, esta tiene una mayor variabilidad debido a una serie de polimorfismos genéticos ${ }^{244}$.

Basándonos en parámetros clínicos una edad avanzada, un alto índice de masa corporal y una FEVI basal baja son unos de los signos que mayor capacidad predictora poseen para el riesgo de toxicidad derivada con antraciclina en un estudio llevado a cabo con 967 pacientes oncológicos ${ }^{245}$. Otros estudios plantean el strain o GLS que tienen las pacientes en periodos anteriores al tratamiento con antraciclinas como un posible factor de riesgo a sufrir este tipo de patología. Este método, basado en la medición de 
la contracción longitudinal de miocardio mediante técnicas ecocardiográficas es capaz de detectar y cuantificar anormalidades en la función sistólica del ventrículo izquierdo ${ }^{246}$, la adición de los valores de strain a un modelo basado en edad, tipo de cáncer e hipertensión aumentaba los valores de predicción de una AUC de 0,7 a una de $0,87.247248$

Hoy en día no tenemos muchos estudios capaces de relacionar una serie de marcadores en forma de miRNAs con una susceptibilidad de sufrir daño por cardiotoxicidad. En el estudio llevado a cabo por Gioffré et al. identifican los miR-122, miR-499a y miR885 como diferencialmente expresados en pacientes con cáncer de mama. En este estudio se consideraba el daño cardiaco como una elevación de la troponina ${ }^{249}$ En nuestro estudio, los niveles de estos miRNAs no aparecen como diferencialmente expresados, esta diferencia puede deberse entre otros casos, tanto a la definición diferente que utilizan como cardiotoxicidad o al hecho de que las muestras de las que parten son de plasma en lugar de suero.

En el estudio llevado a cabo por Xin et al reclutan un total de 363 pacientes diferenciando entre casos y controles en función del descenso de FEVI. Este autor identifica los miRNA let-7f, miRNA-17-5p, miRNA-20a, miRNA-126, miRNA-210 y miRNA-378 como miRNAs que se encuentra con una expresión reducida en pacientes con la cardiotoxicidad. De estos miRNA terminado eligiendo 2 de ellos (miRNA-17-5p y miRNA20a) para elaborar una curva ROC con un AUC de $0.842^{250}$. Cabe destacar que los miRNAs let7f y miR-126 han sido identificados como diferencialmente expresados en nuestro estudio, los cual apoya nuestros resultados, pero no se encuentran validados.

Es importante mencionar que, debido a la alta variabilidad que existe entre los diferentes pacientes en patrones difícilmente equiparables como tipo de tumor, tratamiento o antecedentes cardiacos, resulta de vital importancia una cohorte con un mayor número de pacientes para ayudar a mejorar la exactitud del algoritmo predictor. Sin embargo, los miRNAs descubiertos en este estudio, podrían combinarse con los miRNAs descubiertos por otros autores o incluso con otros parámetros clínicos previamente descritos para desarrollar un algoritmo con un mayor poder predictor.

En los resultados obtenidos del interactoma podemos ver que, en el conjunto los procesos biológicos regulados por la firma de miRNAs diferencialmente expresados, aparecen una serie de procesos relacionados estrechamente con la funcionalidad cardiaca. Concretamente en aquellos procesos con un p valor más bajo, la regulación de los procesos de apoptosis, regulación de fibras de colágeno o regulación del TNF 
son procesos que, si bien no son específicos del tejido cardiaco, su regulación puede ejercer un gran efecto en el tejido cardiaco. Un aumento en la apoptosis de los cardiomiocitos, así como un aumento en las fibras de colágeno puede dar lugar a la formación de fibrosis cardiaca, disminuyendo de este modo su capacidad contráctil. En el caso del TNF $\alpha$ ciertos autores han demostrado su papel central en los procesos de fibrosis aunque también puede afectar de manera importante a los cardiomiocitos. Se ha demostrado que la doxorrubicina en cardiomiocitos es capaz de afectar a los receptores I y II del TNF $\alpha$ modulando de esta manera la apoptosis de los mismos ${ }^{251}$. En el caso de la vía de NFкB su función es variable en función la célula en la que se encuentre, por ejemplo, la activación de este factor en células endoteliales y miocitos tratados con doxorrubicina ejerce un efecto pro-apoptótico mientras que en célula cancerígenas ejerce una función anti-apoptótica ${ }^{252}$, de hecho se ha estudiado como posible vía terapéutica con la limitación de que una supresión de este factor puede inducir un crecimiento tumoral así como inflamación cardiaca 253254.

Los resultados a su vez muestran procesos específicos del corazón como Procesos cardiacos, Contracción cardiaca, Regulación de la contracción cardiaca. Además de procesos involucrados en el funcionamiento del musculo estriado como contracción del músculo estriado, o regulación de los movimientos de los filamentos de actina.

En cuanto a vías de señalización podemos ver que aparece la IL4, esta citoquina de carácter antiinflamatorio no se encuentra relacionada con procesos de toxicidad cardiaca aunque si se ha estudiado como un inhibidor de la apoptosis celular ${ }^{255}$.. En el caso de la IL1, aunque se encuentra comprobado que esta puede aumentar después de un tratamiento con doxorubicina ${ }^{256}$ se considera como una respuesta inflamatoria al daño por estrés celular que causa la droga. Sin embargo, el hecho de que esta vía se encuentre diferencialmente expresada antes de tratar con la droga puede deberse a que pacientes con alteraciones en esta vía tienen niveles anormales de esta citoquina desarrollando por lo tanto una respuesta diferente en niveles inflamatorios después del tratamiento con las antraciclinas.

Como conclusión podemos postular que existe una serie de miRNAs que se encuentran alterados en los pacientes con predisposición a sufrir procesos de cardiotoxicidad. La herramienta desarrollada en este trabajo nos permite detectar esta firma alterada de miRNAs antes de que los pacientes reciban la quimioterapia y actuar en consecuencia en función de los resultados. Los pacientes con la firma alterada podrían recibir dosis más bajas de quimioterapia o formatos menos agresivos como la doxorrubicina liposomal además de incluir fármacos cardioprotectores para ellos. Esta herramienta 
predictiva poco invasiva puede suponer un aumento en la supervivencia de los pacientes tratados con antraciclinas, así como un aumento en su calidad de vida.

\section{El papel de las vesículas derivadas de MSC-TERT en la terapia contra el daño inducido por la doxorrubicina.}

Actualmente, las nuevas terapias generadas para la lucha contra el cáncer, así como su detección temprana aumentan de manera considerable la esperanza de vida de estos pacientes. Sin embargo, estos tratamientos tumorales tienen como consecuencia algunos efectos adversos cardiacos pudiendo llegar a causar la muerte de los pacientes. En este contexto el uso de estas drogas anticancerígenas debe ser minuciosamente monitorizado para poder detectar este tipo de eventos. Aunque los mecanismos por los cuales estas drogas afectan al corazón han sido estudiados, todavía no tenemos un conocimiento pleno de los mismos. La generación de estrés oxidativo se plantea como una de las principales fuentes de daño en este tipo celular haciendo especialmente vulnerables a las células cardiacas ya que estas cuentan con una menor cantidad de mecanismos antioxidantes como superóxido dismutasa o catalasa ${ }^{257}$. Por todo ello es de vital importancia la generación de un tratamiento que nos permita limitar este daño cardiaco, así como generar una menor fibrosis cardiaca combinada con un aumento de la angiogénesis.

En primer lugar, es de vital importancia resaltar la inmortalización de la línea celular de MSCs. La generación de una línea estable a través de los pases celulares permite la obtención de vesículas sin variaciones dependientes de los múltiples pases celulares así como un mayor crecimiento de la línea sin que esta entre en senescencia. Dado que el objetivo final de este trabajo es generar un producto con un potencial terapéutico la cantidad de vesículas a extraer debe partir de un volumen celular extremadamente grande para cubrir tratamientos a mamíferos superiores. Esto imposibilita la utilización de una línea no inmortalizada siendo la única alternativa la utilización de diversas biopsias a lo largo de los procesos de generación de vesículas, sin embargo, pueden existir variaciones en las capacidades terapéuticas en función del donante de las MSCs.

Teniendo estas en cuenta estas consideraciones nuestros resultados demuestran que una vez introducido de manera eficiente el gen TERT en las MSCs conseguimos una expansión continuada de las MSCs sin que estas entren en periodo de senescencia y sin perder los marcadores celulares que las definen como célula mesenquimal. 
Los resultados aportados en este trabajo apuntan a estas vesículas como una posible herramienta terapéutica que puede ser de gran importancia para el tratamiento de la cardiotoxicidad. La administración de $15 \mu \mathrm{g} / \mathrm{mL}$ de vesículas genera una reducción de ROS así como de células en apoptosis que puede ser de vital ayuda para el mantenimiento y buen funcionamiento del tejido cardiaco. Diversos autores ya han publicado el uso de EVs para el tratamiento del daño por doxorrubicina a partir de diversas fuentes, por ejemplo el usos de EVs derivadas de células madre cardiacas mejora la función, reduce la fibrosis y el número de células TUNEL positivas en un modelo murino de toxicidad cardiaca inducida por doxorubicina ${ }^{258}$. En otros estudios se utilizan EVs modificando a la célula progenitora sin carácter terapéutico como son HEK293T, para aumentar la concentración de algunos agentes que pueden ser beneficiosos para el tratamiento de la toxicidad cardiaca ${ }^{259}$ e incluso algunos autores han utilizado las vesículas derivadas del células cardiacas obtenida como posible marcador de daño cardiaco ${ }^{260}$.

Aunque las células MSCs ya se habían estudiado en el daño por doxorrubicina por diversos autores ${ }^{261-264}$ no se encuentra demasiado estudiado el papel de las vesículas derivadas de MSCs en la cardiotoxicidad. Nuestros resultados demuestran que estas vesículas son capaces de reducir la cantidad de doxorrubicina presente en los cardiomiocitos después de su tratamiento. Este hecho nos podría hacer pensar que quizá las EVs están captando parte de las doxorrubicina que se incluye en el medio de cultivo, sin embargo algunos autores utilizan estas vesículas para encapsular la propia doxorrubicina y que esta genere menor cardiotoxicidad describen que es necesario una electroporación de la vesícula para generar una captación de la doxorubicina ${ }^{265}$. Para comprobar si las EVs se encontraban secuestrando la doxorrubicina y por lo tanto perturbando su posible efecto terapéutico añadimos estas mismas EVs junto con doxorrubicina a una línea celular de cáncer de mama no observando diferencias en la muerte producida ni en la cantidad de doxorrubicina captada por las líneas tumorales. Esto nos hace pensar que realmente las EVs contienen una serie de factores que promueven la expulsión temprana de la doxorrubicina en los cardiomiocitos

Nuestros resultados muestran a su vez como la doxorrubicina afecta a la viabilidad de fibroblastos y células endoteliales. En el caso de los fibroblastos estos juegan un papel de vital importancia en el remodelado cardiaco pudiendo generar procesos fibróticos que afecten al funcionamiento del corazón. Nuestros resultados demuestran que un tratamiento con vesículas extracelulares reduce la expresión de genes pro-fibróticos como el COL 1 y COL III y a su vez disminuye la capacidad de migración de los mismos. Actualmente algunos estudios muestran la capacidad anti-fibrótica de las EVs 
derivadas de MSCs ${ }^{266-268}$ corroborando de esta manera los resultados obtenidos en este estudio. En la modelización in vivo de este daño por doxorubicina podemos ver que los ratones tratados con EVs de manera intraperitoneal son capaces de reducir la mortalidad así como ejercer un papel protector frente a la pérdida de peso de los mismos. En los resultados posteriores no se pudo demostrar que el modelo generara una fibrosis cardiaca capaz de ser detectada con el método empleado, este hecho quizá se deba al modelo empleado para realizarlo, teniendo en cuenta que la dosis utilizada de doxorrubicina podía incluso llegar a ser letal en algunos animales, no nos planteamos que la falta de fibrosis cardiaca observada se deba a una dosis baja del fármaco.

En los pacientes cardiacos tratado con doxorubicina los problemas cardiacos crónicos relacionados con las bajadas de FEVI aparecen en una fase tardía e incluso cuando finaliza el tratamiento lo que nos hace pensar que nuestro modelo necesitaría de más tiempo a unas dosis más bajas para que se puedan observar fibrosis cardiaca. En un experimento con dosis similares se observó que el aumento de fibrosis medido por Sirius Red en ratas tratadas con adriamicina aumentaba unicamente en un $2 \%{ }^{269}$ mientras que en otro artículo solo encuentran aumento de la señal en las regiones perivasculares $^{270}$.

Este resultado a su vez muestra el efecto sistémico de la doxorrubicina. Se encuentra altamente estudiado que la doxorrubicina genera daños en diversos órganos aparte del corazón pudiendo deberse los casos de mortalidad en los animales a afectaciones en los mismos. El aumento de supervivencia que se aprecia en los ratones tratados con vesículas junto con el resultado negativo de la fibrosis cardiaca apuntan a que las vesículas se encuentran ejerciendo su efecto terapéutico en otros posibles órganos. Esto concuerda con el hecho de que las EVs pueden presentar un tropismo hacia zonas con daño o inflamadas como el hígado o el intestino, explicando también de esta manera la menor pérdida de peso en estos animales. Sin embargo, es necesario un estudio en mayor profundidad en estos órganos para poder asegurar estas afirmaciones.

En cuanto a las células endoteliales se encuentra descrito que las EVs derivadas de MSCs son capaces de generar efectos pro-angiogénicos en células endoteliales ${ }^{271-273}$ en nuestro caso podemos comprobar como las células endoteliales las cuales han sufrido un descenso en su viabilidad debido al daño por la doxuribicina, son capaces de generar una mayor cantidad de estructuras tubulares cuando estas células son estimuladas con las vesículas derivadas de MSCs. Esto puede deberse a diversos 
factores pro-angiogénicos que van dentro de las EVs derivadas de MSC como pueden ser IFGBP, TIMP-1, Angtp-1 o VEGF 274

\section{4. miRNAs en el tratamiento de la patología cardiaca}

En el primer apartado de esta tesis hemos visto como una serie de miRNAs se encuentran involucrados en la función y desarrollo cardiaco, así como la respuesta de este órgano a situaciones de daño o estrés. Estos miRNAs nos sirvieron para desarrollar una firma de miRNAs que nos servían para discriminar entre pacientes que tienen una predisposición a sufrir eventos de cardiotoxicidad frente aquellos que no. Seguidamente, comprobamos que las vesículas extracelulares derivadas de MSCs tenían un potencial terapéutico en diferentes poblaciones cardiacas, por lo que buscamos la presencia de estos miRNAs en las vesículas derivadas de MSCs, siendo todos ellos encontrados en las EVs en diferentes proporciones. Estos miRNAs a su vez se encuentran regulados por la presencia de doxorrubicina cuando esta se añade sobre un cultivo de cardiomiocitos como podemos observar en los resultados. De estos miRNAs los miRNA-150, miRNA-486, miRNA-148a y miRNA-4732 ejercen un efecto protector en los cardiomiocitos frente al daño por doxorrubicina. Los miRNAs 150, 148a y 486 ya habían sido descritos en estudios anteriores a este como posibles agentes terapéuticos en la terapia cardiaca ${ }^{231,237,275-279}$ sin embargo el miRNA 4732$3 p$ se postula como un nuevo miRNA sin apenas estudios en la terapia cardiaca siendo a su vez el miRNA de mayor efecto protector en los cardiomiocitos. Además, nuestros experimentos corroboran que la adicción de este miRNA no ejerce un efecto protumoral en líneas celulares de cáncer de mama por lo que centramos el estudio de miRNA en el miRNA-4732-3p a partir de este momento.

A continuación, se describe como el aumento mediante transfección de este miRNA ejerce un papel protector frente al daño por doxorrubicina. Después de corroborar este efecto se plantea su utilización en otros tipos de daño como puede ser la miocardiopatía isquémica. Como se ha descrito en el apartado de introducción la patología isquémica es una de las enfermedades más prevalentes y de mayor comorbilidad en países desarrollados. El hecho de que no existan terapias relevantes en este ámbito pone de manifiesto la complejidad de la patología ya que se trata de un efecto multifactorial que desemboca en la insuficiencia cardiaca.

Si bien es cierto que hasta ahora se han logrado ciertos avances en el desarrollo de terapias para tratar el daño por isquemia/reperfusión, la dificultad de modelizar la 
enfermedad, así como la urgencia inherente a la patología dificultan enormemente este trabajo. Por ello y cada vez de manera más urgente se están desarrollando terapias a un nivel multidisciplinar que apliquen las nuevas tecnologías en conjunto con los conocimientos biológicos sobre la materia, así como simulaciones computacionales que nos permitan un enfoque más global de la patología.

En este trabajo se intenta, desde una perspectiva orientada en la terapia celular, ofrecer una posible herramienta terapéutica para el tratamiento de los pacientes con esta patología. En este sentido se ha querido comparar el efecto de las vesículas extracelulares derivadas de MSCs con el efecto del miRNA-4732-3p con el objetivo último de determinar si un único miRNA es capaz de recopilar los efectos terapéuticos de las EVs en el modelo de daño de isquemia.

En el análisis de miRNAseq podemos comprobar que la diferencia de miRNAs que existe entre las células MSC y MSC-TERT es prácticamente nula compartiendo un 99,17\% de los miRNAs entre ambas. Este resultado nos permite utilizar las EVs de MSC-TERT como una fuente de EVs de similar contenido a las células sin inmortalizar. 2656 miRNA encontrados en las vesículas 2633 son comunes entre ambas, mientras que solo 22 son encontrados únicamente en MSC-TERT pero no en las MSC normales mientras que un solo miRNA se encuentra en las MSC pero no en las MSC-TERT, ninguno de estos miRNAs diferenciales son los miRNAs descritos en los anteriores apartados de esta tesis como relevantes en la patología cardiaca.

Como se puede comprobar en la Fig 37 el miRNA-4732-3p es parcialmente responsables de la función terapéutica de las EVs, en este experimento podemos ver como sometiendo a las vesículas a un proceso de electroporación en el cual las vesículas pierden parte de su contenido, su capacidad terapéutica disminuye. Sin embargo, estas mismas vesículas las cuales se electroporan para introducir el miRNA 4732-3p recuperan esta capacidad terapéutica frente al daño por isquemia, con un efecto similar a la introducción únicamente del miRNA por vesículas de lipofectamina. Las pruebas de imagen por microscopia electrónica y NTA nos indican que las EVs que se encuentran electroporadas mantienen su morfología sin cambios, tampoco se observan modificaciones relevantes en el número de partículas obtenidas por NTA. De esta manera descartamos que la pérdida de potencial terapéutico que se observa en los experimentos se deba en realidad a que las vesículas se están destruyendo en el proceso de electroporación o este disminuyendo su número de manera significativa. A partir de este punto y observando que se obtienen similares resultados de supervivencia utilizando vesículas electroporadas con el miRNA y con el miRNA encapsulado en 
liposomas, utilizamos únicamente el miRNA encapsulado en liposomas comparado a las vesículas sin modificar. El hecho de utilizar vesículas electroporadas reduce la cantidad de vesículas extraídas de gran manera. Por este motivo y teniendo en cuenta la homogeneidad y repetibilidad de los liposomas decidimos centrarnos en ellos en lugar de las vesículas electroporadas.

En los siguientes experimentos vemos que el miRNA aúna la mayoría de las propiedades de las EVs como reducción de ROS, reducción de producción de lactato, o reducción de niveles de Caspasa 3 procesada. Anteriores autores ya han descrito como a través de las EVs derivadas de MSCs se reduce el número de células que entran en estado de apoptosis reduciendo marcadores de muerte celular como Bax o las Caspasa $3^{191,194,280}$. A su vez nuestros resultados demuestran como las vesículas creadas con lipofectamina que contienen el miRNA-4732-3p son capaces de replicar el efecto de las vesículas derivadas de las MSCs a partir de mecanismos de reducción de estrés oxidativo.

En la Fig 40 se muestra como la adicción de EVs derivadas de MSCs es capaz de proteger la capacidad contráctil de los cardiomiocitos durante el periodo de isquemia mientras que el miRNA 4732-3p no muestra una mejora significativa. Nuestros resultados a su vez muestran que la adicción de EVs produce en los cardiomiocitos un aumento significativo de la proteína Conexina 43. Esta proteína juega un papel relevante en las uniones gap que se producen entre los cardiomiocitos, siendo de vital importancia por lo tanto en la sincronización de latidos que se produce en el músculo cardiaco $^{281,282}$. Así pues, el aumento de esta proteína en los cardiomiocitos tratados con EVs puede mejorar la comunicación que existe entre los cardiomiocitos creando más uniones gap, estas uniones extra podrían estar actuando como derivaciones que mantendrían la comunicación celular y por la tanto preservarían el latido a pesar de la muerte celular que se esté produciendo. Los resultados muestran que la adicción de miRNA 4732-3p no aumenta la cantidad de Cnx43, lo cual respalda el resultado obtenido por las MSCs ya que en el caso de los cardiomiocitos tratados con el miRNA4732-3p tampoco vemos una protección de la capacidad contráctil.

En cuanto a la fibrosis que se produce después de un periodo de isquemia hemos querido modelizar este proceso mediante la retirada del suero a los medios de cultivo, y la adicción de TGF $\beta$. Esta citoquina se libera al medio después del proceso de isquemia e induce la transición del fibroblasto original a un miofibroblasto, con mayor capacidad de proliferación, migración y generación de matriz extracelular. 
Nuestros resultados demuestran que la adición de vesículas extracelulares no induce una mayor o menor migración en los fibroblastos mientras que la adición del miRNA 4732-3p induce una menor migración de estos. Después de conocer estos resultados se decide buscar marcadores típicos de la transición a miofibroblasto. Los resultados obtenidos mediante inmunofluorescencia muestran una mayor cantidad de expresión de las proteínas como Col1A y $\alpha$-SMA.

En artículos anteriores se demostró que el miRNA 4732-3p reduce la expresión de proteínas SMAD2 y SMAD4. Como se ha comentado en apartados anteriores el TGF $\beta$ activa la expresión de ciertas dianas de SMAD4 en las que se incluyen p21, bim, y bax que reducen la viabilidad celular y la proliferación. ${ }^{226} 227$ Por lo que una inhibición por parte del miRNA-4732 de las proteínas SMAD2 y SMAD4 tendrían como consecuencia un aumento de la viabilidad celular y un aumento de la proliferación. Cabe destacar que, acorde con nuestros resultados, un estudio de posibles dianas del miRNA 4732-3p colocan proteínas tales como el receptor de TGF- $\beta$ o FGFR2 y 4como posibles dianas del miRNA aunque sería necesario un estudio más exhaustivo para comprobar la unión de este miRNA a esas posibles dianas.

Los experimentos de angiogénesis in vivo e in vitro muestran un amento en la formación de estructuras tubulares, así como un aumento de células CD31 positivas. Diversas bases de datos muestran que el miRNA-4732-3p puede ser diana del interferon que actúa como inhibidor de la angiogénesis, aunque no parece existir interacción con otras proteínas fuertemente relacionadas con la formación de vasos como la angiotensina, VEGF o EGF. Sin embargo el TGF- $\beta$ ha demostrado ser un mediador importante en fenómenos de angiogénesis en diferentes estudios considerándose angiogénico ${ }^{283,284} \mathrm{o}$ anti- angiogénico en diversas situaciones ${ }^{285,286}$. Concretamente el miRNA 4732 tiene como diana el receptor del TGF-b1 que es capaz de modelar la matriz extracelular en las células endoteliales pudiendo alterar el patrón de expresión de otros receptores de TGF- $\beta$ como el TGF- $\beta$ II de carácter antiangiogénico. Teniendo estos resultados en cuenta podemos deducir que la adición de miRNA 4732-3p se encuentre inhibiendo los receptores de TGF- $\beta$ I y en consecuencia los de TGF-B II generando por lo tanto un efecto pro-angiogénico 287

En lo referente a los análisis en los modelos in vivo el miRNA 4732-3p ha demostrado ser capaz de aumentar el número de células endoteliales en un plug de matrigel inyectado de manera subdérmica durante 15 días. Además, reduce de manera considerable el tamaño del infarto así como induce una mejora en los parámetros ecocardiográficos de fracción de acortamiento o cambio porcentual de área. Todos 
estos resultados nos permiten postular al miRNA como una posible herramienta terapéutica para el daño por isquemia, no únicamente aumentando la supervivencia de los cardiomiocitos sino desarrollando una mayor cantidad de irrigación en la zona infartada mediante su efecto angiogénico y disminuyendo la fibrosis. Cabe destacar que una inhibición excesiva de la fibrosis puede ser perjudicial ya que es necesaria una respuesta rápida para cerrar la herida inicial, pero teniendo en cuenta que en los modelos animales la cardioregeneración se ve aumentada, este último efecto podría compensar la fibrosis rápida necesaria. Diversos autores en la literatura ya han demostrado que se puede aumentar los parámetros de funcionalidad cardiaca mediante la acción de miRNAs, sin embargo, es de vital importancia controlar los efectos de estos miRNAs ya que pueden dar lugar a una proliferación de cardiomiocitos que pueden ser beneficiosos en primera instancia, pero dar lugar finalmente a alteraciones en los electrocardiogramas. 


\section{CONCLUSIONES}


- Existe una comunicación activa entre las poblaciones cardiacas a través de las Evs. Esta comunicación a su vez es dependiente del estado en el que se encuentran las células productoras de las EVs adaptando su contenido en función del mismo.

- Las pacientes con una predisposición a sufrir eventos de cardiotoxicidad tienen un perfil de miRNAs diferente a las pacientes sanas con el cual somos capaces de predecir los eventos de cardiotoxicidad a partir de dichos miRNAs

- Los miRNA-30b, miRNA-92b, miRNA-148a, miRNA-150, miRNA-192, miRNA-215, miRNA-486 y miRNA-4732 se encuentran involucrados en la función cardiaca afectando a procesos biológicos y genes relacionados con el corazón, siendo algunos de ellos de carácter protector en modelos in vitro de daño por doxorrubicina.

- La sobreexpresión de algunos de estos miRNAs, especialmente el miRNA 4732-3p tanto a nivel de cardiomiocitos como en fibroblastos y células endoteliales ejerce un efecto protector, antifibrótico y pro-angiogénico in vitro e in vivo no solo en el daño por doxorrubicina sino en otras patologías como la patología isquémica

- Las vesículas derivadas de MSCs pueden actuar como una posible herramienta terapéutica para el tratamiento del daño por doxorrubicina o la isquemia cardiaca. 


\section{BIBLIOGRAFÍA}


1. Murphy, S. P., Ibrahim, N. E. \& Januzzi Jr, J. L. Heart Failure With Reduced Ejection Fraction: A Review. JAMA 324, 488-504 (2020).

2. Arrigo, M. et al. Acute heart failure. Nat. Rev. Dis. Prim. 6, 16 (2020).

3. Berthiaume, J. M. et al. Chapter 8 - Pathophysiology of Heart Failure and an Overview of Therapies. in (eds. Buja, L. M. \& Butany, J. B. T.-C. P. (Fourth E.) 271-339 (Academic Press, 2016). doi:https://doi.org/10.1016/B978-0-12420219-1.00008-2.

4. Vasan, R. S. et al. Congestive heart failure in subjects with normal versus reduced left ventricular ejection fraction: Prevalence and mortality in a population-based cohort. J. Am. Coll. Cardiol. 33, 1948-1955 (1999).

5. Cowie, M. R. et al. Incidence and aetiology of heart failure; a populationbased study. Eur. Heart J. 20, 421-428 (1999).

6. Mcmurray, J. J. \& Stewart, S. Epidemiology, aetiology, and prognosis of heart failure. Educ. Hear. 83, 596-602 (2000).

7. Stansfield, W. E. \& Ranek, M. The Pathophysiology of Cardiac Hypertrophy and Heart Failure. Cellular and Molecular Pathobiology of Cardiovascular Disease (Elsevier, 2014). doi:10.1016/B978-0-12-405206-2.00004-1.

8. Cook, C., Cole, G., Asaria, P., Jabbour, R. \& Francis, D. P. The annual global economic burden of heart failure is. Int. J. Cardiol. 171, 368-376 (2014).

9. Ebrahim, S. et al. Multiple risk factor interventions for primary prevention of coronary heart disease. Cochrane Database Syst. Rev. (2011) doi:10.1002/14651858.CD001561.pub3.

10. Després, J.-P., Lemieux, I., Dagenais, G.-R., Cantin, B. \& Lamarche, B. HDLcholesterol as a marker of coronary heart disease risk: the Québec cardiovascular study. Atherosclerosis 153, 263-272 (2000).

11. Mahdy Ali, K., Wonnerth, A., Huber, K. \& Wojta, J. Cardiovascular disease risk reduction by raising HDL cholesterol--current therapies and future opportunities. Br. J. Pharmacol. 167, 1177-1194 (2012).

12. Rigotti, N. A. \& Clair, C. Managing tobacco use: the neglected cardiovascular disease risk factor. Eur. Heart J. 34, 3259-3267 (2013).

13. Kyle, S., Michael, T., Cathy, L. \& Clark, H. Environmental Tobacco Smoke and Coronary Heart Disease in the American Cancer Society CPS-II Cohort. Circulation 94, 622-628 (1996).

14. Gopal, D. M. et al. Cigarette smoking exposure and heart failure risk in older adults: the Health, Aging, and Body Composition Study. Am. Heart J. 164, 236-242 (2012).

15. Lloyd-jones, D. M. et al. Lifetime Risk for Developing Congestive Heart Failure The Framingham Heart Study. Circulation 106, 3068-3072 (2002).

16. Subramaniam, V. \& Lip, G. Y. H. Hypertension to heart failure: a 
pathophysiological spectrum relating blood pressure, drug treatments and stroke. Expert Rev. Cardiovasc. Ther. 7, 703-713 (2009).

17. Oh, G. C. \& Cho, H.-J. Blood pressure and heart failure. Clin. Hypertens. 26, 1 (2020).

18. Alpert, M. A., Lavie, C. J., Agrawal, H., Aggarwal, K. B. \& Kumar, S. A. Obesity and heart failure: epidemiology, pathophysiology, clinical manifestations, and management. Transl. Res. 164, 345-356 (2014).

19. Ms, S. C., Lavie, C. J. \& Pt, R. A. Obesity and Heart Failure: Focus on the Obesity Paradox. Mayo Clin. Proc. 92, 266-279 (2017).

20. Horwich, T. B., Fonarow, G. C. \& Clark, A. L. Obesity and the Obesity Paradox in Heart Failure. Prog. Cardiovasc. Dis. 6, 151-156 (2018) doi:10.1016/j.pcad.2018.05.005.

21. Heusch, G. \& Gersh, B. J. The pathophysiology of acute myocardial infarction and strategies of protection beyond reperfusion : a continual challenge. 774784 (2017) doi:10.1093/eurheartj/ehw224.

22. Reports, C. \& Heart, I. N. Ischemic Cardiomyopathy and Heart Failure. 10-12 (2019) doi:10.1056/NEJMra032393.

23. Schwinger, R. H. G. Pathophysiology of heart failure. Cardiovasc. Diagn. Ther. 11, 263-276 (2021).

24. Khan, M. A. et al. Global Epidemiology of Ischemic Heart Disease: Results from the Global Burden of Disease Study. Cureus 12, e9349 (2020).

25. Nowbar, A. N., Gitto, M., Howard, J. P., Francis, D. P. \& Al-Lamee, R. Mortality From Ischemic Heart Disease. Circ. Cardiovasc. Qual. Outcomes 12, e005375 (2019).

26. Gheorghe, A. et al. The economic burden of cardiovascular disease and hypertension in low- and middle-income countries: a systematic review. BMC Public Health 18, 975 (2018).

27. Kristensen, S. D. et al. Interventional cardiology Reperfusion therapy for ST elevation acute myocardial infarction 2010 / 2011 : current status in 37 ESC countries. 1957-1970 (2014) doi:10.1093/eurheartj/eht529.

28. Wu, M.-Y. et al. Current Mechanistic Concepts in Ischemia and Reperfusion Injury. Cell. Physiol. Biochem. Int. J. Exp. Cell. Physiol. Biochem. Pharmacol. 46, 1650-1667 (2018).

29. Physiology, C. Current Mechanistic Concepts in Ischemia and Reperfusion Injury. 1650-1667 (2018) doi:10.1159/000489241.

30. Chen, W. \& Li, D. Reactive Oxygen Species (ROS)-Responsive Nanomedicine for Solving Ischemia-Reperfusion Injury. Front. Chem. 8, 732 (2020).

31. Cadenas, S. ROS and redox signaling in myocardial ischemia-reperfusion 
injury and cardioprotection. Free Radic. Biol. Med. 117, 76-89 (2018).

32. Chung, H. Y. et al. Xanthine dehydrogenase/xanthine oxidase and oxidative stress. Age (Omaha). 20, 127-140 (1997).

33. Lee, M.-C.-I., Velayutham, M., Komatsu, T., Hille, R. \& Zweier, J. L. Measurement and characterization of superoxide generation from xanthine dehydrogenase: a redox-regulated pathway of radical generation in ischemic tissues. Biochemistry 53, 6615-6623 (2014).

34. Andrienko, T. N., Pasdois, P., Pereira, G. C., Ovens, M. J. \& Halestrap, A. P. The role of succinate and ROS in reperfusion injury - A critical appraisal. $J$. Mol. Cell. Cardiol. 110, 1-14 (2017).

35. Granger, D. N. \& Kvietys, P. R. Reperfusion injury and reactive oxygen species: The evolution of a concept. Redox Biol. 6, 524-551 (2015).

36. Brandes, R. P., Weissmann, N. \& Schröder, K. Nox family NADPH oxidases: Molecular mechanisms of activation. Free Radic. Biol. Med. 76, 208-226 (2014).

37. Phillips, L., Toledo, A. H., Lopez-Neblina, F., Anaya-Prado, R. \& ToledoPereyra, L. H. Nitric Oxide Mechanism of Protection in Ischemia and Reperfusion Injury. J. Investig. Surg. 22, 46-55 (2009).

38. Valko, M. et al. Free radicals and antioxidants in normal physiological functions and human disease. Int. J. Biochem. Cell Biol. 39, 44-84 (2007).

39. Crabtree, M. J. et al. Quantitative Regulation of Intracellular Endothelial Nitric-oxide Synthase ( eNOS ) Coupling by Both Tetrahydrobiopterin-eNOS Stoichiometry and. J. Biol. Chemi 284, 1136-1144 (2009).

40. Kalogeris, T., Bao, Y. \& Korthuis, R. J. Mitochondrial reactive oxygen species : A double edged sword in ischemia / reperfusion vs preconditioning. Elsevier 2, 702-714 (2014).

41. Liu, H., Jing, X., Dong, A., Bai, B. \& Wang, H. Overexpression of TIMP3 Protects Against Cardiac Ischemia/Reperfusion Injury by Inhibiting Myocardial Apoptosis Through ROS/Mapks Pathway. Cell. Physiol. Biochem. 44, 1011-1023 (2017).

42. Del Re, D. P., Amgalan, D., Linkermann, A., Liu, Q. \& Kitsis, R. N. Fundamental Mechanisms of Regulated Cell Death and Implications for Heart Disease. Physiol. Rev. 99, 1765-1817 (2019).

43. Wetzel, M. D. \& Wenke, J. C. Mechanisms by which hydrogen sulfide attenuates muscle function following ischemia-reperfusion injury: effects on Akt signaling, mitochondrial function, and apoptosis. J. Transl. Med. 17, 33 (2019).

44. Dhesi, P., Tehrani, F., Fuess, J. \& Schwarz, E. R. How does the heart (not) die? The role of autophagy in cardiomyocyte homeostasis and cell death. Heart Fail. Rev. 15, 15 (2009). 
45. Gustafsson, A. B. \& Gottlieb, R. A. Eat your heart out: Role of autophagy in myocardial ischemia/reperfusion. Autophagy 4, 416-421 (2008).

46. Zheng, Y., Shi, B., Ma, M., Wu, X. \& Lin, X. The novel relationship between Sirt3 and autophagy in myocardial ischemia-reperfusion. J. Cell. Physiol. 234, 5488-5495 (2019).

47. Lin, X.-L., Xiao, W.-J., Xiao, L.-L. \& Liu, M.-H. Molecular mechanisms of autophagy in cardiac ischemia/reperfusion injury (Review). Mol. Med. Rep. 18, 675-683 (2018).

48. McCully, J. D., Wakiyama, H., Hsieh, Y.-J., Jones, M. \& Levitsky, S. Differential contribution of necrosis and apoptosis in myocardial ischemiareperfusion injury. Am. J. Physiol. Circ. Physiol. 286, H1923-H1935 (2004).

49. Ruiz-meana, M. \& García-dorado, D. Pathophysiology of IschemiaReperfusion Injury : New Therapeutic Options for Acute Myocardial Infarction. Rev Esp Cardiol 62, 199-209 (2009).

50. Kukreja, R. C. \& Janin, Y. Reperfusion Injury: Basic Concepts and Protection Strategies. J. Thromb. Thrombolysis 4, 7-24 (1997).

51. Lu, L., Liu, M., Sun, R., Zheng, Y. \& Zhang, P. Myocardial Infarction: Symptoms and Treatments. Cell Biochem. Biophys. 72, 865-867 (2015).

52. Bolli, R. \& Marbán, E. Molecular and Cellular Mechanisms of Myocardial Stunning. Physiol. Rev. 79, 609-634 (1999).

53. Schafer, J., Montz, R. \& Mathey, D. G. Scintigraphic Evidence of the " No Reflow " Phenomenon in Human Beings After Coronary Thrombolysis. J. Am. Coll. Cardiol. 5, 593-598 (1985).

54. Hiroshi, I. et al. Clinical Implications of the 'No Reflow' Phenomenon . Circulation 93, 223-228 (1996).

55. Janda, S. P. \& Tan, N. Thrombolysis versus primary percutaneous coronary intervention for ST elevation myocardial infarctions at Chilliwack General Hospital. Can. J. Cardiol. 25, e382-e384 (2009).

56. Lettino, M. Why and when PCI, why and when thrombolysis? Intern. Emerg. Med. 4, 7-9 (2009).

57. Joy, E. R., Kurian, J. \& Gale, C. P. Comparative effectiveness of primary PCI versus fibrinolytic therapy for ST elevation myocardial infarction: a review of the literature. J. Comp. Eff. Res. 5, 217-226 (2016).

58. Kandzari, D. E. et al. Reduction of myocardial ischemic injury following coronary intervention (the MC-1 to Eliminate Necrosis and Damage trial). Am. J. Cardiol. 92, 660-664 (2003).

59. Kohlhauer, M. et al. Protection against cardiac ischemia-reperfusion injury by hypothermia and by inhibition of succinate accumulation and oxidation is additive. Basic Res. Cardiol. 114, 18 (2019). 
60. Ko, W., Lin, C., Lee, J., Chang, C. \& Chao, C. Therapeutic Hypothermia Protects Against Heat Stroke-Induced Arterial Hypotension via Promoting Left Ventricular Performance in Rats. Int. J. Med. Sci. 17, (2020).

61. Dae, M. W., Gao, D. W., Sessler, D. I., Chair, K. \& Stillson, C. A. Effect of endovascular cooling on myocardial temperature, infarct size, and cardiac output in human-sized pigs. Am. J. Physiol. Heart Circ. Physiol. 282, H158491 (2002).

62. Marek-Iannucci, S. et al. Myocardial hypothermia increases autophagic flux, mitochondrial mass and myocardial function after ischemia-reperfusion injury. Sci. Rep. 9, 10001 (2019).

63. Mentzer Jr, R. M., Lasley, R. D., Jessel, A. \& Karmazyn, M. Intracellular sodium hydrogen exchange inhibition and clinical myocardial protection. Ann. Thorac. Surg. 75, S700-S708 (2003).

64. Avkiran, M. \& Marber, M. S. Na+/h+exchange inhibitors for cardioprotective therapy: progress, problems and prospects. J. Am. Coll. Cardiol. 39, 747-753 (2002).

65. Théroux, P. et al. Inhibition of the sodium-hydrogen exchanger with cariporide to prevent myocardial infarction in high-risk ischemic situations. Main results of the GUARDIAN trial. Guard during ischemia against necrosis (GUARDIAN) Investigators. Circulation 102, 3032-3038 (2000).

66. Ruiz-Meana, M. et al. Protective effect of HOE642, a selective blocker of $\mathrm{Na}+\mathrm{H}+$ exchange, against the development of rigor contracture in rat ventricular myocytes. Exp. Physiol. 85, 17-25 (2000).

67. Garcia-Dorado, D. et al. Prevention of ischemic rigor contracture during coronary occlusion by inhibition of $\mathrm{Na}+-\mathrm{H}+$ exchange. Cardiovasc. Res. 35, 80-89 (1997).

68. Agunbiade, T. A., Zaghlol, R. Y. \& Barac, A. Heart Failure in Relation to Anthracyclines and Other Chemotherapies. Methodist Debakey Cardiovasc J 15, (2019).

69. Cardinale, D., Iacopo, F. \& Cipolla, C. M. Cardiotoxicity of Anthracyclines. Front. Cardiovasc. Med. 7, 26 (2020).

70. Cardinale, D., Iacopo, F. \& Cipolla, C. M. Cardiotoxicity of Anthracyclines. Front. Cardiovasc. Med. 7, 3-5 (2020).

71. Volkova, M. \& Russell 3rd, R. Anthracycline cardiotoxicity: prevalence, pathogenesis and treatment. Curr. Cardiol. Rev. 7, 214-220 (2011).

72. Henriksen, P. A. Anthracycline cardiotoxicity: an update on mechanisms, monitoring and prevention. Heart 104, 971 LP - 977 (2018).

73. Bloom, M. W. et al. Cancer Therapy-Related Cardiac Dysfunction and Heart Failure: Part 1: Definitions, Pathophysiology, Risk Factors, and Imaging. Circ. Heart Fail. 9, e002661 (2016). 
74. Plana, J. C. et al. Expert consensus for multimodality imaging evaluation of adult patients during and after cancer therapy: a report from the American Society of Echocardiography and the European Association of Cardiovascular Imaging. Eur. Heart J. Cardiovasc. Imaging 15, 1063-1093 (2014).

75. Alvarez-cardona, J. \& Lenihan, D. J. Anthracycline Cardiotoxicity It Is Possible to Teach an Old Dog Some New Tricks. Cardiol. Clin. 37, 355-363 (2019).

76. Sandri, M. T. et al. Minor Increases in Plasma Troponin I Predict Decreased Left Ventricular Ejection Fraction after High-Dose Chemotherapy. Clin. Chem. 252, 248-252 (2003).

77. Chemotherapy, H. et al. Prognostic Value of Troponin I in Cardiac Risk Stratification of Cancer Patients Undergoing. Circulation 2749-2754 (2004) doi:10.1161/01.CIR.0000130926.51766.CC.

78. Tan, L.-L. \& Lyon, A. R. Role of Biomarkers in Prediction of Cardiotoxicity During Cancer Treatment. Curr. Treat. Options Cardiovasc. Med. 20, 55 (2018).

79. Maceo Montesino, N., Rives Figueredo, M., Pérez García, Y. \& Meriño Collazo, L. Péptido Natriurético tipo B. Utilidad clínica. Rev. Med. Isla la Juv. Vol. 14, Número 1 Enero-Junio (2013).

80. Meessen, J. M. T. A. et al. Circulating biomarkers and cardiac function over 3 years after chemotherapy with anthracyclines : the ICOS-ONE trial. i, 1-15 (2020).

81. Lenihan, D. J. et al. The Utility of Point-of-Care Biomarkers to Detect Cardiotoxicity During Anthracycline Chemotherapy: A Feasibility Study. J. Card. Fail. 22, 433-438 (2016).

82. Lipshultz, S. E. et al. Changes in cardiac biomarkers during doxorubicin treatment of pediatric patients with high-risk acute lymphoblastic leukemia: associations with long-term echocardiographic outcomes. J. Clin. Oncol. Off. J. Am. Soc. Clin. Oncol. 30, 1042-1049 (2012).

83. Plana, J. C. et al. Expert Consensus for Multimodality Imaging Evaluation of Adult Patients during and after Cancer Therapy: A Report from the American Society of Echocardiography and the European Association of Cardiovascular Imaging. J. Am. Soc. Echocardiogr. 27, 911-939 (2014).

84. Zhang, S. et al. Identification of the molecular basis of doxorubicin-induced cardiotoxicity. Nat. Med. 18, 1639-1642 (2012).

85. Minotti, G., Ronchi, R., Salvatorelli, E., Menna, P. \& Cairo, G. Doxorubicin irreversibly inactivates iron regulatory proteins 1 and 2 in cardiomyocytes: evidence for distinct metabolic pathways and implications for iron-mediated cardiotoxicity of antitumor therapy. Cancer Res. 61, 8422-8428 (2001).

86. Simůnek, T. et al. Anthracycline-induced cardiotoxicity: overview of studies examining the roles of oxidative stress and free cellular iron. Pharmacol. Rep. 


$$
\text { 61, 154-171 (2009). }
$$

87. Sawyer, D. B., Peng, X., Chen, B., Pentassuglia, L. \& Chew, C. Mechanisms of Anthracycline Cardiac Injury: Can we identify strategies for cardioprotection? Prog Cardiovasc Dis 53, 105-113 (2011).

88. Salazar-Mendiguchía, J. et al. Anthracycline-mediated cardiomyopathy: Basic molecular knowledge for the cardiologist. Arch. Cardiol. México 84, 218-223 (2014).

89. Montaigne, D., Hurt, C. \& Neviere, R. Mitochondria death/survival signaling pathways in cardiotoxicity induced by anthracyclines and anticancer-targeted therapies. Biochem. Res. Int. 2012, 951539 (2012).

90. Lim, C. C. et al. Anthracyclines induce calpain-dependent titin proteolysis and necrosis in cardiomyocytes. J. Biol. Chem. 279, 8290-8299 (2004).

91. Herman, D. S. et al. Truncations of titin causing dilated cardiomyopathy. $N$. Engl. J. Med. 366, 619-628 (2012).

92. Deidda, M. et al. Novel insights in pathophysiology of antiblastic drugsinduced cardiotoxicity and cardioprotection. J. Cardiovasc. Med. (Hagerstown). 17 Suppl 1, e76-e83 (2016).

93. Farías, J. G. et al. Antioxidant Therapeutic Strategies for Cardiovascular Conditions Associated with Oxidative Stress. Nutrients 9, (2017).

94. Henriksen, P. A. Anthracycline cardiotoxicity : an update on mechanisms, monitoring and prevention. 971-977 (2018) doi:10.1136/heartjnl-2017312103.

95. Marinello, J., Delcuratolo, M. \& Capranico, G. Anthracyclines as Topoisomerase II Poisons: From Early Studies to New Perspectives. Int. J. Mol. Sci. 19, 3480 (2018).

96. Capranico, G. \& Zunino, F. Structural Requirements for DNA Topoisomerase II Inhibition by Anthracyclines BT - Molecular Basis of Specificity in Nucleic Acid-Drug Interactions. in (eds. Pullman, B. \& Jortner, J.) 167-176 (Springer Netherlands, 1990).

97. Langer, S. W. Dexrazoxane for the treatment of chemotherapy-related side effects. Cancer Manag. Res. 6, 357-363 (2014).

98. C., M. G. \& Gregory, H. W. Is Myocardial Fibrosis a New Frontier for Discovery in Cardiotoxicity Related to the Administration of Anthracyclines? Circ. Cardiovasc. Imaging 9, e005797 (2016).

99. Mawad, W. et al. Effect of anthracycline therapy on myocardial function and markers of fibrotic remodelling in childhood cancer survivors. Eur. Hear. J. Cardiovasc. Imaging (2020) doi:10.1093/ehjci/jeaa093.

100. Leask, A. Getting to the heart of the matter: new insights into cardiac fibrosis. Circ. Res. 116, 1269-1276 (2015). 
101. Frantz, S., Kelly, R. A. \& Bourcier, T. Role of TLR-2 in the Activation of Nuclear Factor $\square$ B by Oxidative Stress in Cardiac Myocytes *. J. Biol. Chem. 276, 5197-5203 (2001).

102. Schubert, C., Hong, S., Natarajan, L., Mills, P. J. \& Dimsdale, J. E. The association between fatigue and inflammatory marker levels in cancer patients: a quantitative review. Brain. Behav. Immun. 21, 413-427 (2007).

103. Rudzinski, T., Ciesielczyk, M., Religa, W., Bednarkiewicz, Z. \& Krzeminskapakula, M. Doxorubicin-induced ventricular arrhythmia treated by implantation of an automatic cardioverter-defibrillator. Europace 9, 278-280 (2007).

104. Wojtacki, J., Lewicka-nowak, E. \& Leśniewski-kmak, K. Anthracyclineinduced cardiotoxicity : clinical course, risk factors, pathogenesis, detection and prevention - review of the literature. Med Sci Monit 6, 411-420 (2000).

105. Dazzi, H., Kaufmann, K. \& Follath, F. Anthracycline-induced acute cardiotoxicity in adults treated for leukaemia: Analysis of the clinicopathological aspects of documented acute anthracycline-induced cardiotoxicity in patients treated for acute leukaemia at the University Hospital of Zurich,. Ann. Oncol. 12, 963-966 (2001).

106. Appel, J. M., Nielsen, D., Zerahn, B., Jensen, B. V \& Skagen, K. Anthracycline-induced chronic cardiotoxicity and heart failure. Acta Oncol. (Madr). 46, 576-580 (2007).

107. Lipshultz, S. E. et al. Late Cardiac Effects of Doxorubicin Therapy for Acute Lymphoblastic Leukemia in Childhood. N. Engl. J. Med. 324, 808-815 (1991).

108. Watts, R. G. Severe and fatal anthracycline cardiotoxicity at cumulative doses below $400 \mathrm{mg} / \mathrm{m} 2$ : evidence for enhanced toxicity with multiagent chemotherapy. Am. J. Hematol. 36, 217-218 (1991).

109. O'Brien, M. E. R. et al. Reduced cardiotoxicity and comparable efficacy in a phase III trial of pegylated liposomal doxorubicin HCl (CAELYX/Doxil) versus conventional doxorubicin for first-line treatment of metastatic breast cancer. Ann. Oncol. Off. J. Eur. Soc. Med. Oncol. 15, 440-449 (2004).

110. Safra, T. et al. Pegylated liposomal doxorubicin (doxil): reduced clinical cardiotoxicity in patients reaching or exceeding cumulative doses of 500 mg/m2. Ann. Oncol. Off. J. Eur. Soc. Med. Oncol. 11, 1029-1033 (2000).

111. Swain, S. M. et al. Delayed administration of dexrazoxane provides cardioprotection for patients with advanced breast cancer treated with doxorubicin-containing therapy. J. Clin. Oncol. Off. J. Am. Soc. Clin. Oncol. 15, 1333-1340 (1997).

112. Swain, S. M. et al. Cardioprotection with dexrazoxane for doxorubicincontaining therapy in advanced breast cancer. J. Clin. Oncol. Off. J. Am. Soc. Clin. Oncol. 15, 1318-1332 (1997). 
113. Kalay, N. et al. Protective effects of carvedilol against anthracycline-induced cardiomyopathy. J. Am. Coll. Cardiol. 48, 2258-2262 (2006).

114. Georgakopoulos, P. et al. Letters Cardioprotective effect of metoprolol and enalapril in doxorubicin-treated lymphoma patients : A prospective, parallelgroup , randomized , controlled study with 36-month follow-up. 2, 894-907 (2010).

115. Sharkis, S. J., The, E. T., Mcculloch, E. A. \& The, J. E. T. Canadian Stem Cell Scientists Take the Prize. Cell 122, 817-819 (2005).

116. Carvello, M., Lightner, A., Yamamoto, T., Kotze, P. G. \& Spinelli, A. Mesenchymal Stem Cells for Perianal Crohn's Disease. Cells 8, 764 (2019).

117. Gallo, G. et al. Mesenchymal Stromal Cell Therapy in the Management of Perianal Fistulas in Crohn's Disease: An Up-To-Date Review. Medicina (Kaunas). 56, 563 (2020).

118. Kim, I. A brief overview of cell therapy and its product. $J$ Korean Assoc Maxillofac Surg 39, 201-202 (2013).

119. Zhao, Z., Chen, Y., Francisco, N. M., Zhang, Y. \& Wu, M. The application of CAR-T cell therapy in hematological malignancies: advantages and challenges. Acta Pharm. Sin. B 8, 539-551 (2018).

120. Marks, R. \& Finke, J. [The impact of stem cell therapy in hematology and oncology]. Internist (Berl). 47, 467-468,470-478 (2006).

121. Grant, M. L. \& Bollard, C. M. Cell therapies for hematological malignancies: don't forget non-gene-modified t cells! Blood Rev. 32, 203-224 (2018).

122. Asahara, T., Kalka, C. \& Isner, J. M. Stem cell therapy and gene transfer for regeneration. Gene Ther. 7, 451-457 (2000).

123. Kolios, G. \& Moodley, Y. Introduction to stem cells and regenerative medicine. Respiration. 85, 3-10 (2013).

124. Daley, G. Q. Stem cells and the evolving notion of cellular identity. Philos. Trans. R. Soc. London. Ser. B, Biol. Sci. 370, 20140376 (2015).

125. Ragab, A., Barky, E. L., Mostafa, E., Ali, M. \& Mohamed, T. M. Stem Cells, Classi fi cations and their Clinical Applications -. Am. J. Pharmacol. Ther. 1, $1-7$ (2017).

126. Mount, N. M., Ward, S. J., Kefalas, P., Hyllner, J. \& Mount, N. M. Cell-based therapy technology classifications and translational challenges. (2015).

127. Preston, S. L. et al. The new stem cell biology: something for everyone. Mol. Pathol. 56, 86-96 (2003).

128. Zakrzewski, W., Dobrzyński, M., Szymonowicz, M. \& Rybak, Z. Stem cells: past, present, and future. Stem Cell Res. Ther. 10, 68 (2019).

129. Pittenger, M. F. et al. Multilineage Potential of Adult Human Mesenchymal 
Stem Cells. Science (80-. ). 284, 143 LP - 147 (1999).

130. Dominici, M. et al. Minimal criteria for defining multipotent mesenchymal stromal cells . The International Society for Cellular Therapy position statement. Cytotherapy 8, 315-317 (2006).

131. Horwitz, E. M. et al. Clarification of the nomenclature for MSC : The International Society for Cellular Therapy position statement. Cytotherapy 7, 393-395 (2005).

132. Pittenger, M. F. Mesenchymal stem cells from adult bone marrow. Methods Mol. Biol. 449, 27-44 (2008).

133. Mennan, C., Garcia, J., Roberts, S., Hulme, C. \& Wright, K. A comprehensive characterisation of large-scale expanded human bone marrow and umbilical cord mesenchymal stem cells. Stem Cell Res. Ther. 10, 99 (2019).

134. Samsonraj, R. M. et al. Concise Review: Multifaceted Characterization of Human Mesenchymal Stem Cells for Use in Regenerative Medicine. Stem Cells Transl. Med. 6, 2173-2185 (2017).

135. Lucarelli, E. et al. In vitro biosafety profile evaluation of multipotent mesenchymal stem cells derived from the bone marrow of sarcoma patients. $J$. Transl. Med. 12, 95 (2014).

136. Neri, S. Genetic Stability of Mesenchymal Stromal Cells for Regenerative Medicine Applications: A Fundamental Biosafety Aspect. Int. J. Mol. Sci. 20, 2406 (2019).

137. Pittenger, M. F. et al. Mesenchymal stem cell perspective: cell biology to clinical progress. npj Regen. Med. 4, 22 (2019).

138. Laflamme, M. A. \& Murry, C. E. Regenerating the heart. Nat. Biotechnol. 23, 845-856 (2005).

139. Noiseux, N. et al. Mesenchymal stem cells overexpressing Akt dramatically repair infarcted myocardium and improve cardiac function despite infrequent cellular fusion or differentiation. Mol. Ther. 14, 840-850 (2006).

140. Bagno, L., Hatzistergos, K. E., Balkan, W. \& Hare, J. M. Mesenchymal Stem Cell-Based Therapy for Cardiovascular Disease: Progress and Challenges. Mol. Ther. 26, 1610-1623 (2018).

141. Copland, I. B. Mesenchymal stromal cells for cardiovascular disease. J. Cardiovasc. Dis. Res. 2, 3-13 (2011).

142. Sanina, C. \& Hare, J. M. Mesenchymal Stem Cells as a Biological Drug for Heart Disease: Where Are We With Cardiac Cell-Based Therapy? Circ. Res. 117, 229-233 (2015).

143. Kolf, C. M., Cho, E. \& Tuan, R. S. Mesenchymal stromal cells: Biology of adult mesenchymal stem cells: regulation of niche, self-renewal and differentiation. Arthritis Res. Ther. 9, 204 (2007). 
144. Hodgkinson, C. P., Bareja, A., Gomez, J. A. \& Dzau, V. J. Emerging Concepts in Paracrine Mechanisms in Regenerative Cardiovascular Medicine and Biology. Circ. Res. 118, 95-107 (2016).

145. Gallina, C., Turinetto, V. \& Giachino, C. A New Paradigm in Cardiac Regeneration: The Mesenchymal Stem Cell Secretome. Stem Cells Int. 2015, 765846 (2015).

146. Mirotsou, M., Jayawardena, T. M., Schmeckpeper, J., Gnecchi, M. \& Dzau, V. J. Paracrine mechanisms of stem cell reparative and regenerative actions in the heart. J. Mol. Cell. Cardiol. 50, 280-289 (2011).

147. Florea, V. et al. Dose Comparison Study of Allogeneic Mesenchymal Stem Cells in Patients With Ischemic Cardiomyopathy (The TRIDENT Study). Circ. Res. 121, 1279-1290 (2017).

148. Mathiasen, A. B. et al. Bone marrow-derived mesenchymal stromal cell treatment in patients with ischaemic heart failure: final 4-year follow-up of the MSC-HF trial. Eur. J. Heart Fail. 22, 884-892 (2020).

149. Perin, E. C. et al. Adipose-derived regenerative cells in patients with ischemic cardiomyopathy: The PRECISE Trial. Am. Heart J. 168, 88-95.e2 (2014).

150. Karantalis, V. et al. Autologous mesenchymal stem cells produce concordant improvements in regional function, tissue perfusion, and fibrotic burden when administered to patients undergoing coronary artery bypass grafting: The Prospective Randomized Study of Mesenchymal Stem C. Circ. Res. 114, 1302-1310 (2014).

151. Hare, J. M. et al. Randomized Comparison of Allogeneic Versus Autologous Mesenchymal Stem Cells for Nonischemic Dilated Cardiomyopathy: POSEIDON-DCM Trial. J. Am. Coll. Cardiol. 69, 526-537 (2017).

152. Qayyum, A. et al. ADIPOSE DERIVED STROMAL CELLS FOR REFRACTORY ANGINA: RESULTS FROM MYSTROMALCELL TRIAL. J. Am. Coll. Cardiol. 69, 16 (2017).

153. Konoshenko, M. Y., Lekchnov, E. A., Vlassov, A. V \& Laktionov, P. P. Isolation of Extracellular Vesicles: General Methodologies and Latest Trends. Biomed Res. Int. 2018, 8545347 (2018).

154. Hristov, M., Erl, W., Linder, S. \& Weber, P. C. Apoptotic bodies from endothelial cells enhance the number and initiate the differentiation of human endothelial progenitor cells in vitro. Blood 104, 2761-2766 (2004).

155. Abels, E. R. \& Breakefield, X. O. Introduction to Extracellular Vesicles: Biogenesis, RNA Cargo Selection, Content, Release, and Uptake. Cell. Mol. Neurobiol. 36, 301-312 (2016).

156. Théry, C. et al. Minimal information for studies of extracellular vesicles 2018 (MISEV2018): a position statement of the International Society for Extracellular Vesicles and update of the MISEV2014 guidelines. J. Extracell. vesicles 7, 1535750 (2018). 
157. Raposo, G. \& Stoorvogel, W. Extracellular vesicles: Exosomes, microvesicles, and friends. J. Cell Biol. 200, 373 LP - 383 (2013).

158. Escola, J. M. et al. Selective enrichment of tetraspan proteins on the internal vesicles of multivesicular endosomes and on exosomes secreted by human Blymphocytes. J. Biol. Chem. 273, 20121-20127 (1998).

159. Zaborowski, M. P., Balaj, L., Breakefield, X. O. \& Lai, C. P. Extracellular Vesicles: Composition, Biological Relevance, and Methods of Study. Bioscience 65, 783-797 (2015).

160. Bolukbasi, M. F. et al. miR-1289 and 'Zipcode'-like Sequence Enrich mRNAs in Microvesicles. Mol. Ther. Nucleic Acids 1, e10-e10 (2012).

161. Théry, C., Amigorena, S., Raposo, G. \& Clayton, A. Isolation and Characterization of Exosomes from Cell Culture Supernatants and Biological Fluids. Curr. Protoc. Cell Biol. 30, 3.22.1-3.22.29 (2006).

162. Carnino, J. M., Lee, H. \& Jin, Y. Isolation and characterization of extracellular vesicles from Broncho-alveolar lavage fluid: a review and comparison of different methods. Respir. Res. 20, 240 (2019).

163. Onódi, Z. et al. Isolation of High-Purity Extracellular Vesicles by the Combination of Iodixanol Density Gradient Ultracentrifugation and BindElute Chromatography From Blood Plasma. Front. Physiol. 9, 1479 (2018).

164. Gupta, S. et al. An improvised one-step sucrose cushion ultracentrifugation method for exosome isolation from culture supernatants of mesenchymal stem cells. Stem Cell Res. Ther. 9, 180 (2018).

165. Benedikter, B. J. et al. Ultrafiltration combined with size exclusion chromatography efficiently isolates extracellular vesicles from cell culture media for compositional and functional studies. Sci. Rep. 7, 15297 (2017).

166. Taylor, D. D. \& Shah, S. Methods of isolating extracellular vesicles impact down-stream analyses of their cargoes. Methods 87, 3-10 (2015).

167. Greening, D. W., Xu, R., Ji, H., Tauro, B. J. \& Simpson, R. J. A Protocol for Exosome Isolation and Characterization: Evaluation of Ultracentrifugation, Density-Gradient Separation, and Immunoaffinity Capture Methods BT Proteomic Profiling: Methods and Protocols. in (ed. Posch, A.) 179-209 (Springer New York, 2015). doi:10.1007/978-1-4939-2550-6_15.

168. Tataruch-Weinert, D., Musante, L., Kretz, O. \& Holthofer, H. Urinary extracellular vesicles for RNA extraction: optimization of a protocol devoid of prokaryote contamination. J. Extracell. vesicles 5, 30281 (2016).

169. Musante, L., Tataruch, D. E. \& Holthofer, H. Use and isolation of urinary exosomes as biomarkers for diabetic nephropathy. Front. Endocrinol. (Lausanne). 5, 149 (2014).

170. Liangsupree, T., Multia, E. \& Riekkola, M.-L. Modern isolation and separation techniques for extracellular vesicles. J. Chromatogr. A 1636, 
$461773(2021)$

171. Niu, Z. et al. Polymer-based precipitation preserves biological activities of extracellular vesicles from an endometrial cell line. PLoS One 12, e0186534 (2017).

172. Brownlee, Z., Lynn, K. D., Thorpe, P. E. \& Schroit, A. J. A novel 'salting-out' procedure for the isolation of tumor-derived exosomes. J. Immunol. Methods 407, 120-126 (2014).

173. Hung, M. E., Lenzini, S. B., Stranford, D. M. \& Leonard, J. N. Enrichment of Extracellular Vesicle Subpopulations Via Affinity Chromatography. Methods Mol. Biol. 1740, 109-124 (2018).

174. Stranska, R. et al. Comparison of membrane affinity-based method with sizeexclusion chromatography for isolation of exosome-like vesicles from human plasma. J. Transl. Med. 16, 1 (2018).

175. Nakai, W. et al. A novel affinity-based method for the isolation of highly purified extracellular vesicles. Sci. Rep. 6, 33935 (2016).

176. Lotvall, J. et al. Minimal experimental requirements for definition of extracellular vesicles and their functions: A position statement from the International Society for Extracellular Vesicles. J. Extracell. vesicles 3, 26913 (2014).

177. Pascucci, L. \& Scattini, G. Imaging extracelluar vesicles by transmission electron microscopy: Coping with technical hurdles and morphological interpretation. Biochim. Biophys. Acta - Gen. Subj. 129648 (2020) doi:https://doi.org/10.1016/j.bbagen.2020.129648.

178. van der Pol, E. et al. Particle size distribution of exosomes and microvesicles determined by transmission electron microscopy, flow cytometry, nanoparticle tracking analysis, and resistive pulse sensing. J. Thromb. Haemost. 12, 1182-1192 (2014).

179. Brisson, A. R., Tan, S., Linares, R., Gounou, C. \& Arraud, N. Extracellular vesicles from activated platelets: a semiquantitative cryo-electron microscopy and immuno-gold labeling study. Platelets 28, 263-271 (2017).

180. Shah, M. D., Bergeron, A. L., Dong, J.-F. \& López, J. A. Flow cytometric measurement of microparticles: Pitfalls and protocol modifications. Platelets 19, 365-372 (2008).

181. Zhu, S. et al. Light-Scattering Detection below the Level of Single Fluorescent Molecules for High-Resolution Characterization of Functional Nanoparticles. ACS Nano 8, 10998-11006 (2014).

182. Vestad, B., Llorente, A., Neurauter, A., Phuyal, S. \& Kierulf, B. Size and concentration analyses of extracellular vesicles by nanoparticle tracking analysis : a variation study. J. Extracell. Vesicles 6, (2017).

183. Dragovic, R. A. et al. Sizing and phenotyping of cellular vesicles using 
Nanoparticle Tracking Analysis. Nanomedicine Nanotechnology, Biol. Med. 7, 780-788 (2011).

184. Bachurski, D., Schuldner, M., Nguyen, P., Malz, A. \& Reiners, K. S.

Extracellular vesicle measurements with nanoparticle tracking analysis - An accuracy and repeatability comparison between NanoSight NS300 and ZetaView. J. Extracell. Vesicles 8, (2019).

185. Chimenti, I. et al. Relative roles of direct regeneration versus paracrine effects of human cardiosphere-derived cells transplanted into infarcted mice. Circ.

Res. 106, 971-980 (2010).

186. Garcia, N. A., Moncayo-Arlandi, J., Sepulveda, P. \& Diez-Juan, A.

Cardiomyocyte exosomes regulate glycolytic flux in endothelium by direct transfer of GLUT transporters and glycolytic enzymes. Cardiovasc. Res. 109, 397-408 (2016).

187. Gennebäck, N. et al. Growth factor stimulation of cardiomyocytes induces changes in the transcriptional contents of secreted exosomes. J. Extracell. vesicles 2, 10.3402/jev.v2i0.20167 (2013).

188. Matsumoto, S. et al. Circulating p53-responsive microRNAs are predictive indicators of heart failure after acute myocardial infarction. Circ. Res. 113, 322-326 (2013).

189. Minghua, W. et al. Plasma exosomes induced by remote ischaemic preconditioning attenuate myocardial ischaemia/reperfusion injury by transferring miR-24. Cell Death Dis. 9, 320 (2018).

190. Wang, X. et al. Cardiomyocytes mediate anti-angiogenesis in type 2 diabetic rats through the exosomal transfer of miR-320 into endothelial cells. J. Mol. Cell. Cardiol. 74, 139-150 (2014).

191. Hu, M. et al. The harsh microenvironment in infarcted heart accelerates transplanted bone marrow mesenchymal stem cells injury: the role of injured cardiomyocytes-derived exosomes. Cell Death Dis. 9, 357 (2018).

192. Adamiak, M. et al. Induced Pluripotent Stem Cell (iPSC)-Derived Extracellular Vesicles Are Safer and More Effective for Cardiac Repair Than iPSCs. Circ. Res. 122, 296-309 (2018).

193. Khan, M. et al. Embryonic stem cell-derived exosomes promote endogenous repair mechanisms and enhance cardiac function following myocardial infarction. Circ. Res. 117, 52-64 (2015).

194. Liu, L., Zhang, H., Mao, H., Li, X. \& Hu, Y. Exosomal miR-320d derived from adipose tissue-derived MSCs inhibits apoptosis in cardiomyocytes with atrial fibrillation (AF). Artif. cells, nanomedicine, Biotechnol. 47, 3976-3984 (2019).

195. Xiao, J. et al. Cardiac progenitor cell-derived exosomes prevent cardiomyocytes apoptosis through exosomal miR-21 by targeting PDCD4. Cell Death Dis. 7, e2277 (2016). 
196. Freeman, B. T., Kouris, N. A. \& Ogle, B. M. Tracking fusion of human mesenchymal stem cells after transplantation to the heart. Stem Cells Transl. Med. 4, 685-694 (2015).

197. Breitbach, M. et al. Potential risks of bone marrow cell transplantation into infarcted hearts. Blood 110, 1362-1369 (2007).

198. Zhu, W. et al. Mesenchymal stem cell-secreted soluble signaling molecules potentiate tumor growth. Cell Cycle 10, 3198-3207 (2011).

199. Stoltz, J.-F. et al. Stem Cells and Regenerative Medicine: Myth or Reality of the 21th Century. Stem Cells Int. 2015, 734731 (2015).

200. Huang, Y.-C. \& Lai, L.-C. The potential roles of stem cell-derived extracellular vesicles as a therapeutic tool. Ann. Transl. Med. 7, 693 (2019).

201. Horvitz, H. R. \& Sulston, J. E. Isolation and genetic characterization of celllineage mutants of the nematode Caenorhabditis elegans. Genetics 96, 435454 (1980).

202. Li, S.-C. et al. Identification of homologous microRNAs in 56 animal genomes. Genomics 96, 1-9 (2010).

203. Vasudevan, S. Posttranscriptional Upregulation by MicroRNAs. WIREs RNA 3, 311-330 (2012).

204. O’Brien, J., Hayder, H., Zayed, Y. \& Peng, C. Overview of MicroRNA Biogenesis, Mechanisms of Actions, and Circulation. Front. Endocrinol. (Lausanne). 9, 402 (2018).

205. Zhao, Y. et al. Dysregulation of Cardiogenesis, Cardiac Conduction, and Cell Cycle in Mice Lacking miRNA-1-2. Cell 129, 303-317 (2007).

206. da Costa Martins, P. A. et al. Conditional dicer gene deletion in the postnatal myocardium provokes spontaneous cardiac remodeling. Circulation 118, 1567-1576 (2008).

207. Liu, N. et al. microRNA-133a regulates cardiomyocyte proliferation and suppresses smooth muscle gene expression in the heart. Genes Dev. 22, 32423254 (2008).

208. Bernardo, B. C., Ooi, J. Y. Y., Lin, R. C. Y. \& Mcmullen, J. R. miRNA therapeutics: A new class of drugs with potential therapeutic applications in the heart. Future Med. Chem. 7, 1771-1792 (2015).

209. Zhou, S.-S. et al. miRNAS in cardiovascular diseases: potential biomarkers, therapeutic targets and challenges. Acta Pharmacol. Sin. 39, 1073-1084 (2018).

210. Robinson, M. D. \& Smyth, G. K. Moderated statistical tests for assessing differences in tag abundance. Bioinformatics 23, 2881-2887 (2007).

211. Chen, X. \& Ishwaran, H. Random forests for genomic data analysis. Genomics 99, 323-329 (2012). 
212. Waldmann, P., Mészáros, G., Gredler, B., Fürst, C. \& Sölkner, J. Evaluation of the lasso and the elastic net in genome-wide association studies . Frontiers in Genetics vol. 4270 (2013).

213. Gupta, S. \& Knowlton, A. A. HSP60 trafficking in adult cardiac myocytes: role of the exosomal pathway. Am. J. Physiol. Heart Circ. Physiol. 292, H3052-6 (2007).

214. Roura, S. et al. Proteomic signature of circulating extracellular vesicles in dilated cardiomyopathy. Lab. Invest. 98, 1291-1299 (2018).

215. Kim, S.-C. et al. Extracellular heat shock protein 60, cardiac myocytes, and apoptosis. Circ. Res. 105, 1186-1195 (2009).

216. Ong, S.-G. et al. Cross talk of combined gene and cell therapy in ischemic heart disease: role of exosomal microRNA transfer. Circulation 130, S60-9 (2014).

217. Huang, X. \& Zuo, J. Emerging roles of miR-210 and other non-coding RNAs in the hypoxic response. Acta Biochim. Biophys. Sin. (Shanghai). 46, 220-232 (2014).

218. Moore-Morris, T. et al. Resident fibroblast lineages mediate pressure overload-induced cardiac fibrosis. J. Clin. Invest. 124, 2921-2934 (2014).

219. Pertiwi, K. R., Hillman, R. M., Scott, C. A. \& Chilton, E. L. Ischemia Reperfusion Injury Produces, and Ischemic Preconditioning Prevents, Rat Cardiac Fibroblast Differentiation: Role of K(ATP) Channels. J. Cardiovasc. Dev. Dis. 6, 22 (2019).

220. Chaturvedi, P., Kalani, A., Medina, I., Familtseva, A. \& Tyagi, S. C. Cardiosome mediated regulation of MMP9 in diabetic heart: role of mir29b and mir455 in exercise. J. Cell. Mol. Med. 19, 2153-2161 (2015).

221. Pospisilova, S. et al. MicroRNAs in urine supernatant as potential noninvasive markers for bladder cancer detection. Neoplasma 63, 799-808 (2016).

222. Rapado-González, Ó. et al. Human salivary microRNAs in Cancer. J. Cancer 9, 638-649 (2018).

223. Lusardi, T. A. et al. MicroRNAs in Human Cerebrospinal Fluid as Biomarkers for Alzheimer's Disease. J. Alzheimers. Dis. 55, 1223-1233 (2017).

224. Karvinen, S. et al. MicroRNAs in Extracellular Vesicles in Sweat Change in Response to Endurance Exercise . Frontiers in Physiology vol. 11676 (2020).

225. Doss, J. F. et al. A comprehensive joint analysis of the long and short RNA transcriptomes of human erythrocytes. BMC Genomics 16, 952 (2015).

226. Chen, Y.-G., Wang, Z., Ma, J., Zhang, L. \& Lu, Z. Endofin, a FYVE domain protein, interacts with Smad4 and facilitates transforming growth factor-beta signaling. J. Biol. Chem. 282, 9688-9695 (2007). 
227. Dong, X.-M. et al. GATA-2 inhibits transforming growth factor- $\beta$ signaling pathway through interaction with Smad4. Cell. Signal. 26, 1089-1097 (2014).

228. Balsara, R. D. \& Ploplis, V. A. Plasminogen activator inhibitor-1: the doubleedged sword in apoptosis. Thromb. Haemost. 100, 1029-1036 (2008).

229. Harada, H. \& Grant, S. Apoptosis regulators. Rev. Clin. Exp. Hematol. 7, 117 138 (2003).

230. Pritchard, C. C. et al. Blood cell origin of circulating microRNAs: a cautionary note for cancer biomarker studies. Cancer Prev. Res. (Phila). 5, 492-497 (2012).

231. Fan, J., Shi, S., Qiu, Y., Zheng, Z. \& Yu, L. MicroRNA-486-5p downregulation protects cardiomyocytes against hypoxia-induced cell injury by targeting IGF-1. Int. J. Clin. Exp. Pathol. 12, 2544-2551 (2019).

232. Zhu, H.-H. et al. MicroRNA-486-5p targeting PTEN Protects Against Coronary Microembolization-Induced Cardiomyocyte Apoptosis in Rats by activating the PI3K/AKT pathway. Eur. J. Pharmacol. 855, 244-251 (2019).

233. Yu, X.-J. et al. MicroRNA-92b-3p suppresses angiotensin II-induced cardiomyocyte hypertrophy via targeting HAND2. Life Sci. 232, 116635 (2019).

234. Mazzeo, A. et al. Functional analysis of miR-21-3p, miR-30b-5p and miR$150-5 p$ shuttled by extracellular vesicles from diabetic subjects reveals their association with diabetic retinopathy. Exp. Eye Res. 184, 56-63 (2019).

235. Zhao, M., Wang, J., Xi, X., Tan, N. \& Zhang, L. SNHG12 Promotes Angiogenesis Following Ischemic Stroke via Regulating miR-150/VEGF Pathway. Neuroscience 390, 231-240 (2018).

236. Wang, W. et al. MiR-150 promotes angiogensis and proliferation of endothelial progenitor cells in deep venous thrombosis by targeting SRCIN1. Microvasc. Res. 123, 35-41 (2019).

237. Tang, Y. et al. MicroRNA-150 protects the mouse heart from ischaemic injury by regulating cell death. Cardiovasc. Res. 106, 387-397 (2015).

238. Zhang, L. \& Jia, X. Down-regulation of miR-30b-5p protects cardiomyocytes against hypoxia-induced injury by targeting Aven. Cell. Mol. Biol. Lett. 24, 61 (2019).

239. Zhang, X. et al. The microRNA in ventricular remodeling: the miR-30 family. Biosci. Rep. 39, BSR20190788 (2019).

240. Marfella, R. et al. Circulating microRNA changes in heart failure patients treated with cardiac resynchronization therapy: responders vs. nonresponders. Eur. J. Heart Fail. 15, 1277-1288 (2013).

241. Klenke, S. et al. Circulating miR-192 is a prognostic marker in patients with ischemic cardiomyopathy. Future Cardiol. 14, 283-289 (2018). 
242. Kim, H. et al. MicroRNA-148a/b-3p regulates angiogenesis by targeting neuropilin-1 in endothelial cells. Exp. Mol. Med. 51, 1-11 (2019).

243. Vejpongsa, P. \& Yeh, E. T. H. Topoisomerase 2ß: a promising molecular target for primary prevention of anthracycline-induced cardiotoxicity. Clin. Pharmacol. Ther. 95, 45-52 (2014).

244. Kersting, G. et al. Topoisomerase II beta expression level correlates with doxorubicin-induced apoptosis in peripheral blood cells. Naunyn.

Schmiedebergs. Arch. Pharmacol. 374, 21-30 (2006).

245. Upshaw, J. N. et al. Personalized Decision Making in Early Stage Breast Cancer: Applying Clinical Prediction Models for Anthracycline Cardiotoxicity and Breast Cancer Mortality Demonstrates Substantial Heterogeneity of Benefit-Harm Trade-off. Clin. Breast Cancer 19, 259-267.e1 (2019).

246. Krishnasamy, R. et al. Left Ventricular Global Longitudinal Strain (GLS) Is a Superior Predictor of All-Cause and Cardiovascular Mortality When Compared to Ejection Fraction in Advanced Chronic Kidney Disease. PLoS One 10, e0127044-e0127044 (2015).

247. Demissei, B. G. et al. Left ventricular segmental strain and the prediction of cancer therapy-related cardiac dysfunction. Eur. Hear. journal. Cardiovasc. Imaging 22, 418-426 (2021).

248. Rui, Z. et al. Early Detection and Prediction of Anthracycline-Induced Right Ventricular Cardiotoxicity by 3-Dimensional Echocardiography. JACC CardioOncology 2, 13-22 (2020).

249. Gioffré, S. et al. Circulating MicroRNAs as Potential Predictors of Anthracycline-Induced Troponin Elevation in Breast Cancer Patients: Diverging Effects of Doxorubicin and Epirubicin. J. Clin. Med. 9, (2020).

250. Qin, X., Chang, F., Wang, Z. \& Jiang, W. Correlation of circulating proangiogenic miRNAs with cardiotoxicity induced by epirubicin/cyclophosphamide followed by docetaxel in patients with breast cancer. Cancer Biomark. 23, 473-484 (2018).

251. Chiosi, E. et al. Change in TNF-alpha receptor expression is a relevant event in doxorubicin-induced H9c2 cardiomyocyte cell death. J. Interf. cytokine Res. Off. J. Int. Soc. Interf. Cytokine Res. 27, 589-597 (2007).

252. Wang, S. et al. Activation of nuclear factor-kappaB during doxorubicininduced apoptosis in endothelial cells and myocytes is pro-apoptotic: the role of hydrogen peroxide. Biochem. J. 367, 729-740 (2002).

253. Jacobs, H., Bast, A., Peters, G. J., van der Vijgh, W. J. F. \& Haenen, G. R. M. M. The semisynthetic flavonoid monoHER sensitises human soft tissue sarcoma cells to doxorubicin-induced apoptosis via inhibition of nuclear factor- $\kappa$ B. Br. J. Cancer 104, 437-440 (2011).

254. Nijholt, K. T., Westenbrink, B. D. \& de Boer, R. A. Mitochondrial therapy for 
doxorubicin cardiomyopathy: nuclear factor- $\mathrm{kB}$ to the rescue? Cardiovasc. Res. 116, 1092-1094 (2020).

255. Zamorano, J., Mora, A. L., Boothby, M. \& Keegan, A. D. NF-кB activation plays an important role in the IL-4-induced protection from apoptosis. Int. Immunol. 13, 1479-1487 (2001).

256. Sauter, K. A. D., Wood, L. J., Wong, J., Iordanov, M. \& Magun, B. E. Doxorubicin and daunorubicin induce processing and release of interleukin-1 $\beta$ through activation of the NLRP3 inflammasome. Cancer Biol. Ther. 11, 1008-1016 (2011).

257. Elliott, P. Pathogenesis of Cardiotoxicity Induced by Anthracyclines. Semin. Oncol. 33, 2-7 (2006).

258. Vandergriff, A. C. et al. Intravenous Cardiac Stem Cell-Derived Exosomes Ameliorate Cardiac Dysfunction in Doxorubicin Induced Dilated Cardiomyopathy. Stem Cells Int. 2015, 960926 (2015).

259. Martins-Marques, T. et al. Presence of $\mathrm{Cx} 43$ in extracellular vesicles reduces the cardiotoxicity of the anti-tumour therapeutic approach with doxorubicin. $J$. Extracell. vesicles 5, 32538 (2016).

260. Yarana, C. et al. Extracellular Vesicles Released by Cardiomyocytes in a Doxorubicin-Induced Cardiac Injury Mouse Model Contain Protein Biomarkers of Early Cardiac Injury. Clin. cancer Res. an Off. J. Am. Assoc. Cancer Res. 24, 1644-1653 (2018).

261. Zaki, S. M., Algaleel, W. A., Imam, R. A. \& Abdelmoaty, M. M. Mesenchymal stem cells pretreated with platelet-rich plasma modulate doxorubicin-induced cardiotoxicity. Hum. Exp. Toxicol. 38, 857-874 (2019).

262. Mousa, H. S. E., Abdel Aal, S. M. \& Abbas, N. A. T. Umbilical cord bloodmesenchymal stem cells and carvedilol reduce doxorubicin- induced cardiotoxicity: Possible role of insulin-like growth factor-1. Biomed. Pharmacother. 105, 1192-1204 (2018).

263. Lan, H. et al. The emerging therapeutic role of mesenchymal stem cells in anthracycline-induced cardiotoxicity. Cell Tissue Res. 384, 1-12 (2021).

264. Abushouk, A. I. et al. Mesenchymal Stem Cell Therapy for DoxorubicinInduced Cardiomyopathy: Potential Mechanisms, Governing Factors, and Implications of the Heart Stem Cell Debate . Frontiers in Pharmacology vol. 10635 (2019).

265. Bagheri, E. et al. Targeted doxorubicin-loaded mesenchymal stem cellsderived exosomes as a versatile platform for fighting against colorectal cancer. Life Sci. 261, 118369 (2020).

266. Novokreshchenova, A. N. et al. Mesenchymal Stromal Cell-Derived Extracellular Vesicles: Their Features and Impact on Fibrosis and Myogenesis in Vitro. Biochem. (Moscow), Suppl. Ser. A Membr. Cell Biol. 14, 289-297 (2020). 
267. Basalova, N. et al. Secretome of Mesenchymal Stromal Cells Prevents Myofibroblasts Differentiation by Transferring Fibrosis-Associated microRNAs within Extracellular Vesicles. Cells 9, 1272 (2020).

268. Grange, C. et al. Stem cell-derived extracellular vesicles inhibit and revert fibrosis progression in a mouse model of diabetic nephropathy. Sci. Rep. 9, 4468 (2019).

269. Liu, M. et al. Impact of ethyl pyruvate on Adriamycin-induced cardiomyopathy in rats. Exp Ther Med 12, 3201-3208 (2016).

270. Tanaka, R. et al. Reactive fibrosis precedes doxorubicin-induced heart failure through sterile inflammation. ESC Hear. Fail. 7, 588-603 (2020).

271. Gangadaran, P. et al. Extracellular vesicles from mesenchymal stem cells activates VEGF receptors and accelerates recovery of hindlimb ischemia. $J$. Control. Release 264, 112-126 (2017).

272. Wang, N. et al. Mesenchymal stem cells-derived extracellular vesicles, via miR-210, improve infarcted cardiac function by promotion of angiogenesis. Biochim. Biophys. Acta - Mol. Basis Dis. 1863, 2085-2092 (2017).

273. Branscome, H. et al. Stem Cell Extracellular Vesicles and their Potential to Contribute to the Repair of Damaged CNS Cells. J. Neuroimmune Pharmacol. 15, 1-18 (2020).

274. Merckx, G. et al. Angiogenic Effects of Human Dental Pulp and Bone Marrow-Derived Mesenchymal Stromal Cells and their Extracellular Vesicles. Cells 9, 312 (2020).

275. Lange, S. et al. miR-486 is modulated by stretch and increases ventricular growth. JCI Insight 4, (2019).

276. Sun, Y. et al. MiR-486 regulates cardiomyocyte apoptosis by p53-mediated BCL-2 associated mitochondrial apoptotic pathway. BMC Cardiovasc. Disord. 17, 119 (2017).

277. W., F. M. \& J., M. K. MicroRNA Regulation of Atherosclerosis. Circ. Res. 118, 703-720 (2016).

278. Raso, A. et al. Therapeutic Delivery of miR-148a Suppresses Ventricular Dilation in Heart Failure. Mol. Ther. 27, 584-599 (2019).

279. Deng, P. et al. MicroRNA-150 Inhibits the Activation of Cardiac Fibroblasts by Regulating c-Myb. Cell. Physiol. Biochem. 38, 2103-2122 (2016).

280. Ni, J. et al. Exosomes Derived from TIMP2-Modified Human Umbilical Cord Mesenchymal Stem Cells Enhance the Repair Effect in Rat Model with Myocardial Infarction Possibly by the Akt/Sfrp2 Pathway. Oxid. Med. Cell. Longev. 2019, 1958941 (2019).

281. Oyamada, M. et al. The expression, phosphorylation, and localization of connexin 43 and gap-junctional intercellular communication during the establishment of a synchronized contraction of cultured neonatal rat cardiac 
myocytes. Exp. Cell Res. 212, 351-358 (1994).

282. Michela, P., Velia, V., Aldo, P. \& Ada, P. Role of connexin 43 in cardiovascular diseases. Eur. J. Pharmacol. 768, 71-76 (2015).

283. Sankar, S. et al. Modulation of transforming growth factor beta receptor levels on microvascular endothelial cells during in vitro angiogenesis. J. Clin. Invest. 97, 1436-1446 (1996).

284. Roberts, A. B. et al. Transforming growth factor type beta: rapid induction of fibrosis and angiogenesis in vivo and stimulation of collagen formation in vitro. Proc. Natl. Acad. Sci. U. S. A. 83, 4167-4171 (1986).

285. Madri, J. A. et al. Effects of soluble factors and extracellular matrix components on vascular cell behavior in vitro and in vivo: models of deendothelialization and repair. J. Cell. Biochem. 45, 123-130 (1991).

286. Merwin, J. R., Newman, W., Beall, L. D., Tucker, A. \& Madri, J. Vascular cells respond differentially to transforming growth factors beta 1 and beta 2 in vitro. Am. J. Pathol. 138, 37-51 (1991).

287. Ucuzian, A. A., Gassman, A. A., East, A. T. \& Greisler, H. P. Molecular mediators of angiogenesis. J. Burn Care Res. 31, 158-175 (2010). 
